\title{
An Intercropping Bibliography
}

\author{
by
}

\author{
Walter T. Federer
}

\begin{abstract}
This is an extensive bibliography of more than 3,000 references, covering the many and varied aspects of mixed cropping, intercropping, polyculture, or agricultural cropping systems. References on competition, weeds, pastures, orchards, shrubs, trees, or other types when other crops or cultivars are involved, are included. The subjects of rotations, doubling cropping, and no-till or minimum-till cropping are included in the list below. Library software is not yet at the stage where this bibliography could have been obtained. Researchers in the field of intercropping should find this bibliography a valuable aid in their studies on intercropping. Agronomists, ecologists, entomologists, and pathologists working in the areas of mixed plantings will find this bibliography useful.
\end{abstract}

BU-1407-M in the Technical Report Series of the Biometrics Unit, 434 Warren Hall, Cornell University, Ithaca, New York 14853. 


\section{An Intercropping Bibliography}

\section{Introduction}

As may be noted from the following bibliography, there has been considerable research activity in the many and diverse aspects of intercropping. It would appear that many of these studies could have utilized some of the statistical design and analytical procedures in the following two books by the author,

Statistical Design and Analysis for Intercropping Experiments. Volume I. Two Crops

Statistical Design and Analysis for Intercropping Experiments. Volume II. Three or More Crops

in order to obtain and to extract additional information from the experimental data. Extracting all the information from an experiment allows for a more efficient use of research resources. Some of the manners in which the procedures might have been used are discussed in Chapter 79 of Volume II.

The bibliography was obtained as follows:

(i). A computer search of the literature was made in 1983 using BRS After Dark.

(ii). A computer search of the literature was made in 1997 using the Cornell University Mann Gateway Library Resource Agricola.

(iii). A number of $\mathrm{Ph}$. D. theses were obtained and the literature citations in these theses were included.

(iv). Many intercropping reprints, technical reports, and papers obtained by the author were used to supplement those obtained from the above sources.

(v). All issues of the Agronomy Journal, Crop Science, and Experimental Agriculture from 1983 to July of 1997 were checked as were the list of references at the end of each of the papers on intercropping.

Despite this extensive search, there are always some citations that will be missed in any bibliography but it is felt that this bibliography is rather complete. In compiling the bibliography, several citation mistakes were noted. Also, it is possible that mistakes were made by this author. In compiling bibliographies, it has been noted that authors of scientific articles appear to make frequent mistakes in their literature citations. An attempt was made to cross check references whereever possible without always going to the original paper. Whenever the citation was incomplete, it was omitted from the list.

The software computer package MicroSoftWord - 97 was used to sort the references in alphabetical order. The sorting is not what every person might wish but is one form of alphabetical ordering. Also, a scanner was used for some lists and several errors were noted, especially if the printing was less than the best.

Some acronyms for organizations used in the bibliography are:

AAAS - American Association for the Advancement of Science

ACE - Agriculture in Concert with the Environment

ACIAR - Australian Centre for International Agricultural Research

ASA - American Society of Agronomy

CATIE - Centro Agronomico Tropical de Investigacion y Ensenanza

CIAT - Centro Internacional Agricola Tropical, Cali, Columbia 
CIDIA - Centro Internacional de Informacion y Documentacion Agricola

CIMMYT - International Maize and Wheat Improvement Centre, Mexico City, Mexico

CIP - International Potato Center

CSSA - Crop Science Society of America

EMBRAPA - Empressa Brasileira Pesquisa Agropecuaria

FAO - Food and Agriculture Organization, Rome, Italy

FABIS - Faba Bean Information Service

GTZ - German Agency Tech Coop

IAR - Indian Agricultural Research, Samaru

IBGE - Instituto Brasileira Geopraphica Estatistica

ICAR - Indian Council of Agricultural Research

ICARDA - International Center for Agricultural Research in the Dry Areas

ICIPE - International Center of Insect Physiology and Ecology

ICRAF - International Council for Research in Agroforestry

ICRISAT - International Crops Research Institute for Semi-Arid Tropics

IDRC - International Development Research Center, Ottawa, Canada

IFOAM - International Organization for Fertility and Maintenance

IITA - International Institute Tropical Agriculture, Ibadan, Nigeria

IICA - Instituto Interamericano de Ciencias Agricolas

ILCA - International Livestock Centre for Africa

IRRI - International Rice Research Institute, Los Baos, Philippines

NFTA - Nitrogen Fixing Tree Research Reports

OECD - Organization for Economic Cooperation and Development

RENAFE - Reuniao Nacional de Pesquisa de Feijao

RRIM - Rubber Research Institute of Malaya

SARE - Sustainable Agricultural Research Education

SSSA - Soil Science Society of America

USDA - United States Department of Agriculture

\section{Bibliography}

Aarssen, L. W. (1983). Ecological combining ability and competitive combining ability in plants: Toward a general evolutionary theory of coexistence in systems of competition. Amer. Nat. 122:707-731.

Aasen, A. C. and V. S. Baron (1994). Grazing trial using a spring cereal/winter cereal intercrop system. In Proc 1st Circumpolar Agric. Conf., Whitehorse, Yukon (ed: C. A. Scott Smith). Agric Canada, Ottawa, ON, pp.61-63.

Abdel, G. A. M., A. S. Seif, and M. I. Bashir (1991). Effect of intercropping patterns of forage cowpeas with two types of grain sorghum on growth, yield and quality. Adv. Desert Arid Land Technol. Dev. 5:407-421.

Abdel, M. H. M., M. F. Ghoneim, R. K. Rabie, and R. E. Sabrah (1991). Productivity of wheat and alfalfa under intercropping. Expl. Agric. 27:391-395.

Aberg, E., I. J. Johnson, and C. P. Wilsie (1943). Associations between species of grasses and legumes. J. Amer. Soc. Agron. 35:357-369.

Abraham, C. T. and S. P. Singh (1984). Weed management in sorghum - legume intercropping systems. J. Agric. Sci (Camb.) 103:103-115.

Abraham, K. J. (1974). Intercropping in arecanut helps to build up farmers economy. Arecanut Spices Bull. 5(3):73-75.

Acland, J. D. (1971). East African Crops. Longman Group Ltd., London.

Acosta, G. J. A. and V. I. Sanchez (1982). Rainfed maize-bean intercropping in Durango (Crop yields, Mexico). Agric. Tec. Mex. 8:65-75.

Adams, J. E. (1974). Residual effects of crop rotation on water intake, soil loss, and sorghum yield. Agronomy J. 66:299-304. 
Adams, W. E., H. D. Morris, and R. N. Dawson (1970). Effect of cropping systems and nitrogen levels on corn (Zea mays L.) in the Southern Piedmont Region. Agronomy J. 62:655-659.

Adams, W. E., H. D. Morris, J. Giddens, et al. (1973). Tillage and fertilization of corn grown in lespedeza sod. Agronomy J. 65:653-655.

Adams, W. E., J. E. Pallas, Jr., and R. N. Dawson (1970). Tillage methods for corn-sod systems in the Southern Piedmont. Agronomy J. 62:646-649.

Addy, G. (1984). An economic analysis of banana intercropping in the Windward Islands (Costs and returns). Fruits (Paris) 39:100-106, 137, 140, 142.

Adesiyun, A. A. (1983). Some effects of intercropping of sorghum, millet and maize on infestation by lepidopterous stalk-borers, particularly Busseola fusca (Zea mays, Sorghum bicolor, Pennisetum typhoides). Insect Sci. Applica. 4:387-391.

Adetiloye, P. O. (1980). Growth, development and yield in sole and intercropped cowpea (Vigna unguiculata L. Walp.) and maize (Zea mays L.). Ph.D. Thesis, Univ. Ibadan, Nigeria.

Adetiloye, P. O. (1985). A mathematical model for formulating intercrop proportions for intercropping systems' design. Ecol. Model. 27:81-93.

Adetiloye, P. O. and A. A. Adekunle (1989). Concept of monetary equivalent ratio and its usefulness in evaluation of intercropping advantages. Tropical Agric. (Trinidad) 66:337-341.

Adetiloye, P. O., F. O. C. Ezedinma, and B. N. Okigbo (1983). A land equivalent coefficient (LEC) concept for the evaluation of competitive and productive interactions in simple to complex crop mixtures (Intercropping). Ecol. Model. 19:27-39.

Adkins, R. van C. (1988). Intercropping firewood trees with essential oil plants. Banko Janakari J. For. Inf. 2:52-55.

Ae, N., J. Arihara, K. Okada, et al. (1990). Phosphorus uptake by pigeon pea and its role in cropping systems of the Indian subcontinent. Science 248:477-480.

Aflakpui, G. K. S., T. J. Vyn, M. R. Hall, et al. (1993). Effect of tillage on nitrogen response in corn after established alfalfa. Can. J. Plant Sci. 73:73-81.

Agamuthu, P. and W. J. Broughton (1986). Factors affecting the development of the rooting system in young oil palms (Elaeis guineensis Jacq.). Agric. Ecosyst. Environ. 17:173-179.

Agbede, O. O. (1985). Improving agroforestry in Nigeria: effect of plant density and interaction on crop production. For. Ecol. Mgt. 11:231-239.

Agbim, N. N. (1987). The effect of plant and animal waste combinations on intercropping yields in a tropical environment. Biol. Agric. Hort. Int. J. 5:143-154.

Agboola, A. A. and A. A. Fayemi (1971). Preliminary trials on the intercropping of maize with different tropical legumes in western Nigeria. J. Agric. Sci. 77:219-225.

Agboola, A. and A. Fayemi (1970). Interplanting of maize and legumes. II. The effect of phosphorus and intercropping of legumes on the yield of maize. West Afr. J. Biol.. Appl. Chem. 13:31-38.

Agboola, A. and A. Fayemi (1972). Effect of soil management on corn yield and soil nutrients in rain forest zone of western Nigeria. Agronomy J. 64:641-644.

Agboola, A. and A. Fayemi (1972). Fixation and excretion of nitrogen by tropical legumes. Agronomy J. 64:409-412.

Ageeb, O. A. A., F. A. Salih, and M. A. Ali (1989). The effect of sowing date, watering interval and intercropping with sorghum and maize on the yield of faba bean. FABIS (Faba Bean Inf. Serv.) Newsl. 24:8-10.

Aggarwal, P. K., D. P. Garrity, S. P. Liboon, and R. A. Morris (1992). Resource use and plant interactions in a rice-mungbean intercrop. Agronomy J. 84:71-78.

Ahlawat, I. P. S., A. Singh, and R. P. Sharma (1985). Water and nitrogen management in wheat lentil intercropping system under late-sown conditions. J. Agric. Sci. (Camb.) 105:697-701.

Ahlgren, H. L. and O. S. Aamodt (1939). Harmful root interactions as a possible explanation for effects noted between various species of grasses and legumes. J. Amer. Soc. Agron. 31:982-985.

Ahmadsad, G. H. (1983). The influence of corn and soybeans in intercropping on soil fertility using organic and mineral fertilizers. Hohenheim, s.n, $195 \mathrm{pp}$.

Ahmed, N. U., P. E. Hildebrand, and V. R. Carangal (1991). Dual-purpose legumes in rainfed lowland rice-based system in the Philippines. IRRI Res. Pap. Ser., Manila, The Institute, Issue 146, 13 pp. 
Ahmed, S. M. R. Rao (1982). Performance of maize soybean intercrop combination in the tropics. Results of a multi-location study. Field Crops Res. 5(2):147-162.

Aidar, H. (1978). Estudo sobre populacoes de plantas em dois sistemas de culturas associadas de milho e feijao. Tese de Doutorado, Univ. Federal de Vicosa.

Aiken, G. E., W. D. Pitman, C. G. Chambliss, and K. M. Portier (1991). Plant responses to stocking rate in a subtropical grass-legume pasture. Agronomy J. 83:124-129.

Aiyer, A. K. N. (1949). Mixed cropping in India. Indian J. Agr. Sci. 19:439-543.

Akhanda, A. M., J. T. Mauco, V. E. Green, and G. M. Prine (1968). Relay intercropping peanut, soybean, sweetpotato and pigeonpea in corn. Proc. Soil Crop Sci. Soc. 37:95-101.

Akkawi, M. and A. M. Al-Musa (1986). Control of mosaic diseases affecting squash (Cucurbita pepo) in Jordan. I. Effect of intercropping corn, pepper and eggplants in squash fields on the incidence of mosaic disease. Dirasat, Univ. Jordan, 13:157-163.

Akunda, E. M. W., J. O. Midiwo, and C. L. Coulson (1987). Intercropping, plant density and yield components on protein and oil yield of soybean. Les Arbres fixateurs d'azote; L'Amelioration biologique de la fertilite du sol, Dakar, Senegal, Paris: Editions de l'ORSTOM, pp. 384-391.

Akyeampong, E. (1996). The influence of time of planting and spacing on the production of fodder and fuelwood in associations of Calliandra calothyrsus and Pennisetum purpureum grown on contour bunds in the Highlands of Burundi. Expl. Agric. 32:79-85.

Al-Bakry, A. N. M. M. and G. Saran (1985). Studies on castor based intercropping systems under dryland conditions. Indian J. Agron. 30:393-395.

Aldag, R. (1987). Simple and diversified crop rotations approach and insight into agroecosystems. Ecol.

- Stud. Anal. Synth. 61.100-114.

Alexander, M. W. and C. F. Genter (1962). Production of corn and soybeans in alternating pairs rows. Agronomy J. 54:233-234.

Alghali, A. M. (1991). Studies on cowpea farming practices in Nigeria, with emphasis on insect pest control. Trop. Pest Mgt. 37:71-74.

Alghali, A. M. (1993). Intercropping as a component in insect pest management for grain cowpea, Vigna unguiculata Walp production in Nigeria. Insect Sci. Its Application 14:49-54.

Ali, M. (1975). Studies on mixed cropping in Tarai region under unirrigated conditions. Indian J. Agron. 20(4):365-368.

Ali, M. (1985). For higher returns grow arhar in intercropping system. Indian Farming 35:7-9.

Ali, M. (1987). Weed management in pigeonpea-based intercropping. Australian Centr Intl. Agric. Res. (ACIAR), p. 229.

Ali, M. (1988). Weed suppressing ability and productivity of short duration legumes intercropped with pigeonpea under rainfed conditions. Trop. Pest Mgt. 34:384-387.

Ali, M. (1993). Wheat/chickpea intercropping under late-sown conditions. J. Agric. Sci. 121:141-144.

Ali, M. and M. S. Raut (1985). Dry matter accumulation pattern and productivity of sorghum and pigeonpea under different systems of intercropping. Indian J. Agron. 30:271-273.

Ali, M., R. K. Pandey, and C. R. Rawat (1982). Studies on intercropping and weed management in pigeonpea under dryland conditions (Cajanus cajan). Madras Agric. J. Coimbatore 69:474-478.

Allan, W. (1965). The African Husbandman. Oliver \& Boyd, Edinburgh.

Allaway, H. (1957). Cropping systems and soil. 1957 Yearbook of Agriculture, USDA, U. S. Govt. Printing Office, Washington, D,. C., pp. 386-396.

Allen, J. R. and R. K. Obura (1983). Yield of corn, cowpea, and soybean under different intercropping systems. Agronomy J. 75:1005-1009.

Allen, Jr., L. H., T. R. Sinclair, and H. R. Lemon (1976). Radiation and microclimate relationships in multiple cropping systems. In Multiple Cropping. (ed: R. I. Papendick et al.). ASA, Madison, WI, pp. 171-200.

Allison, J. R. and S. L. Ott (1987). Economics of using legumes as a nitrogen source in conservation tillage systems. In The Role of Legumes in Conservation Tillage Systems (ed: J. F. Power). Soil Conserv. Soc. Amer., Ankeny, lowa, pp.145-150.

Allison, P. A. (1941). From farm to forest. Farm Forest 2(2):95-98.

Allmaras, R. R., J. M. Kraft, and J. L. Pikul, Jr. (1987). Lime and gypsum effects on pea root-pathogen inoculum and related factors in a wheat-peas rotation. Agronomy J. 79:439-445. 
Almeida, L. D'A. de, E. A. Bulisani, J. A. Sorinho, and G. de.Sordi (1976). Estudos sobre a consorciacao de amendcim e feijao. Bragantia 35:(20):I-IV.

Alpizar, L.. H. W. Fassbender, J. Heuveldop, et al. (1985). Agro-forestry systems of coffee (Coffea arabica) with laurel (Cordia alliodora) and poro (Erythrina poeppigiana) in Turrialba, Costa Rica. I. Biomass and nutrients. Turrialba 35:233-242.

Altieri, M. (1987). Crop rotation and minimum tillage. In Agroecology: The Scientific Basis of Alternative Agriculture (ed: M. Alteiri). Westview Press, Boulder, CO, pp. 139-147.

Altieri, M. A. and M. Liebman (1986). Insect, weed and plant disease management in multiple cropping systems. In Multiple Cropping Systems (ed; C. A. Francis) Macmillan, New York, pp. 183-218.

Altieri, M. A., C. A. Francis, A. V. Schoonhoven, and J. D. Doll (1978). A review of insect prevalence in maize (Zea mays L.) and bean (Phaseolus vulgaris L.) polycultural systems. Field Crops Res. 1:3349

Alvarez, J. and G. H. Snyder (1984). Effect of prior rice culture on sugarcane yields in Florida. Field Crops Res. 9:315-321.

Alves, F. and F. A. B. de. Menezes (1978). Avaliacao dos efeitos da adubacao e alternativas de consorcio na exploracao do algodoeiro moco. Cienc. Agron. 8(1/2):31-40.

Alvim, R and P. de T. Alvim (1969). Efeito da densidade de plantio no aproveiamento da energia luminosa pelo milho ( Zea mays) et pelo feijao (PhaseoJus vulgaris), em culturas exclusivas e consociadas. Turrialba 19:389-393

Alvim, R. ans P. K. R. Nair (1986). Combination of cacao with other plantation crops: an agroforestry system in southeast Bahia, Brazil. Agroforestry Syst. 4:3-15.

Amador, M. F. and S. R. Gliessman (1990). An ecological approach to reducing external inputs through the use of intercropping. Ecol. Stud. Anal. Synth. 78:146-159.

Amare, G. and R. Kedir (1988). Agroforestry in Kenya. a field guide. Nairobi Rural Afforestation Extension, Forest Dept., $59 \mathrm{pp}$.

Amare, G. and R. Kedir (1989). A field guide. agroforestry in Kenya. Rev. $2^{\text {nd }}$ ed. Nairobi, Rural Afforestation Ext., For. Dept., 48 pp.

American Society of Agronomy (1976). Multiple Cropping. ASA Spec. Publ. No. 27, Madison, WI..

Amoako, A. B. (1983). Observations on the pest status of the striped bean weevil Alcidodes leucogrammus Erichs. on cowpea under intercropping systems in Kenya (Vigna unguiculata). Insect Sci. Applica. 4:351-356.

Amoako, A. B. and E. O. Omolo (1983). Yield losses caused by the stem-/pod-borer complex within maize-cowpea-sorghum intercropping sysstems in Kenya (Maruca testulalis, Atherigona soccata, Busseola fusca, Chilo partellus, Sesamia calamistis, Heliothis armigera). Insect Sci. Applica. 4:3946.

Amoako-Atta, B. and E. K. Kidega (1983). Influence of maize, cowpea and sorghum intercropping systems on stem-pod-borer infestations. Insect Sci. Applica. 4(1/2):47-57.

Ampong-Nyarko, K., K. V. Seshu-Reddy, R. A. Nyang'or, and K. N. Saxena (1994). Reduction of insect pest attack on sorghum and cowpea by intercropping. Entomologia Expt. Applicata 70:179-184.

Anand, S. S. and C. M. Singh (1980). Economics of mixed cropping in wheat in Kangra Vallen. Food Farm. Agric. 12(11):252-253.

Andersen, A. J., V. Haahr, E. S. Jensen, and J. Sandfaer (1983). Effect of N-fertilizer on yield, protein content, and symbiotic N-fixation in Pisum sativum L. grown in pure stand and mixtures with barley. In Perspectives for Peas and Beans As Protein Crops (ed: R. Thompson and R. Casey). Proc. Intl. Symp. on Protein Production From Legumes in Europe, M. Nijhoff Publ., The Hague, pp. 205-218.

Anderson, D. L., D. B. Jones, and G. H. Snyder (1987). Response of a rice-sugarcane rotation to calcium silicate slag on Everglades histosols. Agronomy J. 79:531-535.

Anderson, E. and L. O. Williams (1954). Maize and sorghum as a mixed crop in Honduras. Annals Missouri Botanical Gardens 41(2):213-215.

Andharia, R. M., G. Stanford, and F. W. Schaller (1953). Nitrogen status of Marshall silt loam as influenced by different crop rotations. Soil Sci. Soc. Amer. Proc. 17:247-251.

Andow, D. A. (1991). Vegetational diversity and arthropod population response. Annu. Rev. Entomol. 36:561-586. 
Andow, D. A. (1991). Yield loss to arthropods in vegetationally diverse agroecosystems. Environ. Entomol. 20:1228-1235.

Andrade, M. A., M. A. P. Ramalho, and M. J. B. Andrade (1974). Consorciacao de feijoeiro (Phaseolus vulgaris L.) com cultivares de milho. (Zea mays L.) de porte diferente. Agros 4(2):23-30.

Andrade, M. J. B. de (1976). Competicao entre variedades de feijao (Phaseolus vulgaris L.) em diferentes niveis adubacao. M. S. Tese, Vicosa, U. F. V.

Andrews, D. J. (1970). Relay and intercropping with sorghum at Samaru. Proc. Seminar on Intercropping, Ford Foundation/IITA/IRAT, Ibadan, pp. 1-12.

Andrews, D. J. (1972). Intercropping with Guineacorn - Biological co-operative? Samaru Zaria Inst. Agric. Res. Samaru Agric. Newsl. 14(2):20-22.

Andrews, D. J. (1972). Intercropping with sorghum in Nigeria. Expl. Agric. 8:139-150.

Andrews, D. J. (1974). Responses of sorghum varieties to intercropping. Expl. Agric. 10:57-63.

Andrews, D. J. (1975). Intercropping with sorghum. In Sorghum in the Seventies (ed: N. G. P. Rao and L. R. House). Oxford \& I.B.H. Publishing Co., New Delhi, pp. 544-556.

Andrews, D. J. and A. H. Kassam (1976). The importance of intercropping in increasing world food supplies. In Multiple Cropping (ed: M. Stelly). ASA Spec Publ. no. 27, ASA, CSSA, and SSSA, Madison, WI, pp. 1-10.

Angers, D. A. and G. R. Mehuys (1988). Effects of cropping on macro-aggregation of a marine clay soil. Can. J. Soil Sci. 68:723-732.

Anil, L., D. Mazehari, J. Park, et al. (1996). Intercropping maize with kale: scope, results and preliminary conclusions. In Rotations and Cropping Systems, Horticulture Res. Intl., pp. 399-403.

Anjaneyulu, V. R. (1975). Intercropping of hybrid bajra (Pennisetum typhoides (Burm f.) Stapf. \& C.E. Hubb.) with Arhar (Cajanas cajan L.) under rainfed conditions. M.S. Thesis, IARI, New Delhi.

Anjaneyulu, V. S. R. and D. M. Rao (1956). Mixed cropping sugarcane in Deccan canal tract. Andhra Agric. J. 3:294-299.

Anonymous (1965). Importance of the cowpea in tropical Africa and methods of growing. Cahiers d'Agriculture Pratique de Pays Chaud 4:185-190.

Anonymous (1977). Bibliography on intercropping beans (Phaseolus vulgaris), maize corn, sorgo ( $S$. bicolor), 1950-76. IICA-CIDIA, Turrialba, 2 leaves.

Anonymous (1977). Companion Crops. Paris, Inst. Recherches Agron. Trop. Cultures Vivrieres, 1977, V, 281 leaves.

Anonymous (1977). Models of analysis for polyculture enterprises - cattle raising. Commission of the Eurpoean Communities, Brussels, 102 pp.

Anonymous (1978). Intercropping in the tropics and sub-tropics, 1975-78 annotated bibliography. Annot. Bibliogr. Commonw. Bur. Pastures Field Crops, Hurley, England. 12 pp.

Anonymous (1980). Filling the gap. How to make the best use of available space in your vegetable plot. Greenhouse. Middlesex, Haymarket. 4(9):69.

Anonymous (1980). Le complexe de Sinemataili: paysannatet polyculture. Afr. Agric. No. 54., pp. 45-49.

Anonymous (1981). Inflation feeds, intercropping and some consequences, almond tree cultivation, management. Sacramento, Calif. Almond Growers Exchange. Almond Facts 46(3):19-21.

Anonymous (1981). Intercropping research yields needed information. Mich. Agric. Exp. Sta. Mich. Sci. Action No. 45, pp. 18-19.

Anonymous (1982). Intercropping dry beans in coffee (Phaseolus vulgaris grown as a grain legume). Kenya Cof. 47:169-172.

Anonymous (1991). The better way controlling weeds with intercropping. Natl. Biotech. Policy Center Natl. Wildlife Fed., Washington, D. C., 8 pp.

Anonymous (1993). Intercrops that encourage beneficial insects in cotton. IPM Practitioner 15(3):5.

Anthony, K. R. M. and S. G. Willimott (1957). Cotton interplanting experiments in the southwest Sudan. Empire J. Expl. Agric. 25:29-36.

Antunes, I. F. and M. G. Teixeira (1982). Produtividade de genotipos de feijao em monocultivo e no cultivo associado com milho nas epocas das aguas e de seca em Goiania, Co. Proc. 1st Reuniao Nacional de Pesquisa de Feijao (RENAFE), Goiania, Goias, Brazil, pp. 83-88.

Anuebunwa, F. O. (1992). A bio-economic evaluation of intercropping arrangements in a yam-cassava based cropping system in the rain forest belt of Nigeria. Biol. Agric. Hort. Intl. J. 8:251-260. 
Anuebunwa, F. O. (1994). On-farm evaluation of yam staking material alternatives in a yam-cassava based cropping system in the forest-savanna mosaic belt of Nigeria. Biol. Agric. Hort. 10:179-188.

Anwarhan, H., B. B. Habbayad, and A. G. Zandstra (1977). Effects of population density and nitrogen fertilizer application on the growth of corn and soybean planted as monoculture and intercrop. Saturday Seminar, 29 Oct., IRRI, Los Banos, Philippines.

Anyane, S. L. (1963). Ghana Agriculture. Oxford University Press, London.

Apple, J. L. (1972). Intensified pest management needs for developing nations. Bioscience 22:461-464.

Appleby, A. P., P. D. Olson, and D. R. Colbert (1976). Winter wheat yield reduction from interference by Italian ryegrass. Agronomy J. 68:463-466.

Arakeri, H. R., R. S. Patil, and S. V. Patil (1956). Mixed cropping sugarcane in Deccan tract. Proc. $13^{\text {th }}$ Convention, Deccan Sugar Tech. Assoc., Pt.I., pp. 103-116.

Araujo, A. C., F. R. Freirefilho, and V. Q. Ribeiro (1976). Avaliacao tecnico-economica do sistema consorciado milho feijao ( Vigna) no Estado do Piaui. Terezina, EMBRAPA/UEPAE. pp. 15.

Army, T. J. and J. C. Hide (1959). Effects of green manure crops on dryland wheat production in the Great Plains area of Montana. Agronomy J. 59:196-198.

Arne, O. B. (1976). Influence of shade and intercropping on the incidence of cassaca bacterial blight Xanthomonas manihotis. In Cassava Bacterial Blight; Report of an Interdisciplinary Workshop. pp. 28-29.

Arnon, I. (1972). Crop Production in Dry Regions. Vol. 2. Leonard Hill, London.

Aroksaar, R. (1978). Coconut intercropping and coconut by-products: A bibliography of published literature 1966-1978. Noumea: South Paific Commission IV. 51 pp.

Asaduzzaman, S. M., G. Bright, R. M. Brook, and M. A. Hussaim (1995). A novel system of tossa jute (Corchorus olitorius) husbandry for seed, vegetables and fuelwood. Expl. Agric. 31:205-212.

Ashokan, P. K., R. V. Nair, and K. Sudhakara (1985). Studies on cassava-legume intercropping systems for the oxisols of Kerala State, India. Trop. Agric. 62:313-318, 340.

Asoegwu, S. N. and J. C. Obiefuna (1990). Preliminary evaluation of pineapple mixed-cropping systems for protecting reclaimed gulleys in the tropics: an experiment in southeast Nigeria. Land Degradation Rehabil. 2:237-241.

Aspinall, D. (1960). An analysis of competition between barley and white persicaria. Annals Appl. Biol. 48:637-654.

Aspinall, D. and F. L. Milthorpe (1959). An analysis of competition between barley and white persicaria. I. The effects of growth. Annals Appl. Biol. 47:156-172.

Atta-Krah, A. N. (1990). Alley farming with Leucaena: effect of short grazed fallows on soil fertility and crop yields. Expl. Agric. 26:1-10.

Atta-Krah, A. N. and P. A. Francis (1987). The role of on-farm trails in the evaluation of composite technologies: the case of alley farming in southern Nigeria. Agric. Syst. 23:133-152.

Atta-Krah, A. N., J. E. Sumberg, and L. Reynolds (1986). Leguminous fodder trees in the farming system: an overview of research at the humid zone programme of ILCA in southwestern Nigeria. In Potentials of Forage Legumes in Farming Systems of Sub-Saharan Africa (ed: I. Haque et al.). Proc. Workshop ILCA, Addis Ababa, Ethiopia, pp.307-329.

Atu, U. G. and R. O. Ogbuji (1984). Root-knot susceptibility of crops grown with yam in Nigeria. In Tropical Root Crops: Production and Uses in Africa (ed: E.R. Terry. et al.), Proc. $2^{\text {nd }}$ Triennial Symp. Intl. Soc. Trop. Root Crops, Douala, Cameroon, pp. 147-148.

Atwood, S. S. and R. J. Garber (1942). The evaluation of individual plants of white clover for yielding ability in association with bluegrass. J. Amer. Soc. Agron. 34:1-6.

Auld, D. L., B. L. Bettis, M. J. Dial, and G. A. Murray (1982). Austian winter and spring peas as green manure crops in northern Idaho. Agronomy J. 74:1047-1050.

Austin, M. N. and J. N. Marais (1987). Methods of presenting intercropping results and preliminary results with Zea mays and Phaseolus vulgaris. S. Afr. J. Plant Soil 4:1-6.

Austin, M. P., L. F. M. Fresco, A. O. Nicholls, et al. (1988). Competition and relative yield: estimation and interpretation at different densities and under various nutrient concentrations using Silybum marianum and Cirsium vulgare. J. Ecology 76:157-171. 
Aviles, D. P., J. B. Matiello, A. E. Paulini, and M. R. Pinheiro (1983). Infestations of the coffee leaf miner on the coffee cultivars Catuai and Conilon in intercropped and isolated plantings. Cong. Brasileiro Pesquisas Cafeeiras, Pocos de Caldas (MG), pp. 324-325.

AVV (1978). Experimentation agronomique d'accompagnement. Resultats 1977; Ministre du Development Rural, Haute Volta, 154 pp.

Aweto, A. O. and O. O. Ayanniyi (1992). Effects of shifting and continuous cultivation of cassava (Manihot esculenta) intercropped with maize (Zea mays) on a forest alfisol in south-western Nigeria. J. Agric. Sci. 118:195-198.

Ayeni, A. O., W. B. Duke, and I. O. Akobundu (1984). Weed interference in maize, cowpea and maize/cowpea intercrop in a subhumid tropical environment. III. Influence of land preparation. Weed Res. 24:439-448.

Ayisi, K. K., D. H. Putnam, C. P. Vance, M. P. Russelle, and D. L. Allan (1997). Strip intercropping and nitrogen effects on seed, oil, and protein yields of canola and soybean. Agronomy J. 89:23-29.

Ayres, W. E. (1925). Soybeans: Delta Branch Station. Mississippi Agric. Expt. Sta. Bull. 227. 39 pp.

Ayuk, T. J. A. and H. R. Chhedda (1985). Grain yield potential of some diverse maize (Zea mays L.) morphotypes intercropped with cocoyam (Xanthosoma sagittifolium). Expl. Agric. 21:145-152.

Ayyangar, G. N. R. and M. A. S. Ayyar (1942). Mixed cropping: A review. Madras Agric. J. Coimbatore 30:3-14.

Azam, A. S. N., R. B. Matthews, J. H. Williams, and J. M. Peacock (1990). Light use, water uptake and performance of individual components of a sorghum/groundnut intercrop. Expl. Agric. 26:413-427.

Badaruddin, M. and D. W. Meyer (1986). Herbage and nitrogen yield potential of several forage legumes. In Progress Report: Clovers and Special Purpose Legume Research (ed: R. R. Smith), Vol. 19, Univ. Wisconsin, Madison, WI, pp. 79-83.

Badaruddin, M. and D. W. Myer (1989). Forage legume effects on soil nitrogen and grain yield, and nitrogen nutrition of wheat. Agronomy J. 81:419-424.

Badji, M. and R. Peterson 1990. Analysis of farmer's food production strategy in response to changing environmental conditions. In Agricultural Alternatives and Nutritional Self-sufficiency for a Sustainable Agricultural System That Respects Man and His Environment. Proc. IFOAM Seventh Int Sci. Conf., pp. 135-145.

Baeumer, K. and C. T. de Wit (1968). Competitive interference of plant species in monocultures and mixed stands. Neth. J. Agric. Sci. 16:103-122.

Bagayoko, M., S. C. Mason, and R. J. Sabata (1992). Effects of previous cropping systems on soil nitrogen and grain sorghum yield. Agronomy J. 84:862-868.

Baghel, P. P. S. and D. C. Gupta (1986). Effect of intercropping on root-knot nematode (Meloidogyne javanica) infesting grapevine (var. Perlette). Indian J. Nematol. 16:283-284.

Bagyaraj, D. J. and K. Chalapathy (1970). Studies on the rhizosphere microflora of sorghum as influenced by mixed cropping with four other plant species. Mysore J. Agric. Sci. 4(4):415-425.

Baiamonte, S. (1989). Intercropping alfalfa with citrus in southern California. Calif. Grow. 13:20, 22.

Bailey, C. H. (1914). The composition and quality of wheat grown in mixtures with oats. Agronomy J. 6:204-210.

Bailey, L. D., V. O. Biederbeck, W. A. Rice, and A. E. Slinkard (1989). Annual legumes in wheat rotations improve soil quality and productivity. Proc. Int. Conf., Saskatchewan Inst. Pedology, Univ. Saskatchewan, Saskatoon, pp.50-58.

Bailey, L. H. (1921). The Principles of Vegetable Gardening. Macmillan Co., New York.

Bains, S. S. (1968). Pulses are popular for mixed cropping. Indian Farm. 27:19-22

Baker, C. M. and F. P. C. Blamey (1985). Nitrogen fertilizer effcts on yield and nitrogen uptake of sorghum and soybean, grown in sole cropping and intercropping systems. Field Crop Res. 12:233240.

Baker, E. F. I. (1974). Research into intercropping aspects of farming systems in Nigeria: A system for improvement. In Farming Systems Workshop, ICRISAT, Hyderbad, India, pp. 287-301.

Baker, E. F. I. (1975). Cropping systems and intercropping programme. Cropping Scheme Mtg, Inst. Agric. Res., Ahmadu Bello Univ., Zaria, pp. 4-7.

Baker, E. F. I. (1975). Notes on the experimental cropping systems improvement programme. Cropping Scheme Mtg., Inst. Agric. Res., Ahmadu Bello Univ., Zaria. 
Baker, E. F. I. (1978). Mixed cropping in northern Nigeria. I. Cereals and groundnuts. Expl. Agric. 14:293-298.

Baker, E. F. I. (1979). Mixed cropping in northern Nigeria. II. Cereals and cotton. Expl. Agric. 15:33-40.

Baker, E. F. I. (1979). Mixed cropping in northern Nigeria. III. Mixtures of cereals. Expl. Agric. 15:4148.

Baker, E. F. I. (1980). Mixed cropping in northern Nigeria. IV. Extended trial with cereals and groundnuts. Expl. Agric. 16:361-369.

Baker, E. F. I. (1981). Population, time, and crop mixtures. In Intl. Workshop on Intercropping (ed: R. W. Willey). ICRISAT, Patancheru, India, pp. 52-60.

Baker, E. F. I. and D. W. Norman (1975). Cropping systems in northern Nigeria. Proc. Cropping Systems Workshop, IRRI, Los Banos, Philippines, pp. 334-361.

Baker, E. F. I. and Y. Yusuf (1976). Research with mixed crops at the Institute for Agricultural Research, Samaru, Nigeria. Samaru Conference Paper 10. 28 pp.

Baker, S. H. (1987). Effects of tillage practices on cotton double cropped with wheat. Agronomy J. 79:513-516.

Bakhuis, J. A. and H. J. Kleter (1965). Some effects of associated growth on grass and clover under field conditions. Neth. J. Agric. Sci. 13:200-310.

Balasubramanian, A. and O. Thangevelu (1982). Studies on the intercropping of forage legumes in sorghum. Sorghum Improvement Conf. North America. Sorghum Newsl. 25:44.

Balasubramanian, A., K. V. Selvaraj, M. N. Prasad, and O. Thangevelu (1982). Studies on the intercropping of forage legumes in sorghum (India). Sorghum Newsl. 25:44.

Balasubramanian, V. and L. Sekayange (1990). Area harvests equivalency ratio for measuring efficiency in multiseason intercropping. Agronomy J. 82:519-522.

Balasubramanian, V. and L. Sekayange (1991). Effects of tree legumes in hedgerows on soil fertility changes and crop performance in the semi-arid highlands of Rwanda. Biol. Agric. Hort. Intl. J. 8:17-32.

Baldock, J. O. and R. B. Musgrave (1980). The Aurora rotation study. A statistical and agronomic analysis of the crop yields and their variability. Search Agric. 8:1-15.

Baldock, J. O., R. L. Higgs, W. H. Paulson et al. (1981). Legume and mineral N effects on crop yields in several crop sequences in the upper Mississippi Valley. Agronomy J. 73:885-890.

Baldy, C. (1963). Cultures associees et productivite del'Eau. Ann. Agronomiques 14:489-534.

Balyan, J. S. and J. Seth (1985). Effect of planting geometry and nitrogen fertilization on the intercropping of pearlmillet and clusterbean. Indian J. Agron. 30:522-523.

Balyan, J. S. and J. Seth (1985). Effect of pure and intercropped stands of maize and cowpea on succeeding wheat. Indian J. Agron. 30:177-180.

Balyan, R. S., R. K. Malik, R. S. Panwar, and S. Singh (1991). Competitive ability of winter wheat cultivars with wild oat (Avena ludoviciana). Weed Sci. 39:154-158.

Bandyopadhyay, S. K. and R. De (1986). Nitrogen relationships and residual effects of intercropping sorghum with legumes. J. Agric. Sci. 107:629-632.

Bandyopadhyay, S. K. and R. De (1986). Plant growth and seed yield of sorghum when intercropped with legumes. J. Agric. Sci. 107:621-627.

Bandyopadhyay, S. K. and R. De (1986). Relationship in a legume nonlegume association grown in an intercropping system. Fert. Res. 10:73-82.

Banks, P. A. and S. A. Bundschuh (1989). Johnsongrass control in conventionally tilled and no-tilled soybean with foliar-applied herbicides. Agronomy J. 81:757-760.

Banta, G. R. and R. R. Harwood (1973). The multiple cropping program of IRRI. Seminar on Multi-crop Diversification in Taiwan and Its Relevance to Southeast Asian Countries, Taipei, Taiwan, $20 \mathrm{pp}$.

Banta, G. R. and R. R. Harwood (1975). The multiple cropping program at IRRI. Philippine Econ. J. 24(1 $\& 2)$.

Bantilan, R. T. and R. R. Harwood. (1973). Weed management in intensive cropping systems. Saturday Seminar IRRI, Los Banos, Laguna, Philippines, $7 \mathrm{pp}$.

Bantilan, R. T. M. C. Palada, and R. R. Harwood (1974). Integrated weed management. I. Key factors effecting (sic) crop-weed balance. Philippine Weed Sci. Bull. 1(2):14-36. 
Barber, S. A. (1972). Relation of weather to the influence of hay crops on subsequent corn yields on a Chalmers silt loam. Agronomy J. 64:8-10.

Barnakov, N. V. (1963). Aspects of introducing an inter-row cropping system in the Buriat A.S.S.R. Buriatskoe knizhnoe izd-vo, Ulan-Ude, 298 pp.

Barnes, J. P. and A. R. Putman (1983). Rye residues contribute to weed suppression in no-tillage cropping systems. J. Chem. Ecol. 9:1045-1057.

Barnes, J. P. and A. R. Putman (1986). Evidence for allelopathy by residues and aqueous extracts of rye (Secale cereale). Weed Sci. 34:384-390.

Barnett, F. L. and G. L. Posler (1983). Performance of cool-season perennial grasses in pure stands and in mixtures with legumes. Agronomy J. 75:582-586.

Barnett, V. and J. Riley (1995). Statistics for environmental change. Expl. Agric. 31:117-130.

Barnhart, S. K. (1983). Interseeding and no-till pasture renovation. Iowa State Coop. Ext. Service Pamphlet, PM-1097, Iowa State Univ., Ames, Iowa.

Baron, V. S., H. G. Najda, D. F. Salmon, and A. C. Dick (1992). Post-flowering forage potential of spring and winter cereal mixtures. Can. J. Plant Sci. 72:137-145.

Baron, V. S., H. G. Najda, D. F. Salmon, et al. (1993). Cropping systems for spring and winter cereals under simulated pasture: Sward structure. Can. J. Plant Sci. 73:947-959.

Barrentine, W. L. (1974). Common cocklebur competition in soybeans. Weed Sci. 22:600-603.

Bartholomew, W. V., W. D. Shrader, and A. J. Englehorn (1957). Nitrogen changes attending various crop rotations on Clarion-Webster soils in Iowa. Agronomy J. 49:415-418.

Basak, R. K., R. R. Halder, and N. C. Debnath (1987). Efficiency of biosuper as fertilizer in sesame-rice cropping sequence in non-acid soil. Environ. Ecol. 5:537-540.

Basilio, F. A., M. Benincasa, and M. M. P. Benincasa (1975). Estudo preliminar das culturas de sorgo (Sorghum bicolor L. Moench) e feijao (Phaseolus vulgaris L.) em condicoes de consorcio. Cientifica, Jaboticabal:3(1):16-25.

Basu, A. K. (1985). Research achievements of all-India coordinated cotton improvement project with particular reference to achievements in fertiliser use research. Fert. News 30:35-42.

Batra, H. N. (1962). Mixed cropping and pest attack. Indian Farmer 11(11):17-19. 25, 11(12):23-40.

Battese, G. E. and W. A. Fuller (1972). Determination of economic optima from crop-rotation experiments. Biometrics 28:781-792.

Battese, G. E., W. A. Fuller, and W. D. Shrader (1972). Analysis of crop-rotation experiments, with application to the Iowa Carrington-Clye rotation-fertility experiments. Iowa Agric. Expt. Sta. Bull. 574:579-595.

Bautista, B. R. (1918). The production of grain and stalks by maize as affected by intercropping with legumes. Philippine Agric. 7:36-43.

Bavale, B. L. and G. R. Vyahalkar (1981). Studies on planting pattern, intercropping and nitrogen economy in NHH-1 ( Godvarai) hybrid cotton under rainfed condition. Cotton Dev. 11(1):1-3.

Bavappa, K. V. A. and V. J. Jacob (1981). A model for mixed cropping, Kandian Forest Gardens, Sri Lanka. Ceres. Rome, FAO, United Nations 14(3):44-46.

Bawell, A. G. (1974). Irrigation on a mixed cropping farm. Proc. Lincoln College Farmers Conf., $24^{\text {th }}$, pp. 97-102.

Baylor, J. E. (1974). Satisfying the nutritional requirements of grass/legume mixtures. In Forage Fertilization (ed: D. A. Mays). ASA, CSSA, and SSSA, Madison WI, pp. 171-188.

Bazan, R, J. Soria, G. Paez, et al. (1975). Desarollo de sistemas de produccion agricola, una necessidad para el tropico. Fitotecnia Latinoamericana 11(1):53-57.

Beale, O. W. and G. W. Langdale (1967). Tillage and residue management practices for soybean production in a soybean-small grain rotation. Agronomy J. 59:31-33.

Beatty, K. D. and I. L. Eldridge (1979). Results from crop rotation study, Keiser. Arkansas Farm Res. 29:6.

Beaty, E. R. and J. Giddens (1962). Effects of various mthods on seedbed preparation and cultivation of corn grown folling rye. Agronomy J. 54:431-432.

Bebawi, F. F. and R. E. L. Naylor (1981). Performance of pure and mixed stands of forage grasses at the establishment phase. 1, 2 and 3 species mixtures. New Phytol. 89(2):347-356. 
Becker, M., K. H. Diekmann, J. K. Ladha, S.K. Da Datta, and J. C. G. Ottow (1991). Effect of NPK on growth and nitogen fixation of Sesbonia rosttrata as green manure for lowland rice. Plant Soil 132:149-158.

Beets, W. C. (1975). Multiple cropping practices in Asia and the Far East. Agric. Environ. 2:219-228.

Beets, W. C. (1977). Multiple cropping of maize and soybeans under a high level of crop management. Neth. J. Agric. Sci. 25(2):95-102.

Beets, W. C. (1982). Multiple Cropping and Tropical Farming Systems. Gower Publ. Co., Aldershot, UK.

Begonia, G. B. and B. L. Mercado (1974). Evaluation of herbicides for weed control in cabbage-tomato intercropping system. Weed Sci. Rep. 1973-74, Dept. Agronomy, Univ. Philippines. pp. 38-40.

Belcher, C. R. and J. L. Ragland (1972). Phosphorus absorption by sod-planted corn from surface applied phosphorus. Agronomy J. 64:754-756.

Belesky, D. P., S. R. Wilkinson, R. N. Dawson, and J. E. Eisner (1981). Forage production of a tall fescue sod intercropped with sorghum $\times$ sudangrass and rye. Agronomy J. 73:657-660.

Bell, D. T. and D. E. Koeppe (1972). Noncompetitive effects of giant foxtail on the growth of corn. Agronomy J. 64:321-325.

Belleville, B. (1981). Florida polyculture operation cultures, markets prawns for livestock purposes. Aquaculture Mag. 7(5):4-5.

Belzile, L., H. Pelletier, M. Auger, and R. Desjardins (1983). Productivity of alfalfa and timothy grown in pure and mixed stands at La Pocatiere. Canadex Rep., Agric. Canada, Ottawa.

Benites, J. R. (1981). Nitrogen response and cultural practices for corn-based cropping systems in the Peruvian Amazon. Ph.D. Thesis, North Carolina State Univ., Raleigh.

Benneh, G. (1972). Systems of agriculture in tropical agriculture. Econ. Geogr. 48(3):245-257.

Bennett, J. P. and V. C. Runeckles (1977). Effects of low levels of ozone on plant competition. J. Appl. Ecol. 14(3):877-880.

Bennett, O. L., E. L. Mathias, and C. B. Sperow (1976). Double cropping for hay and no-tillage corn production as affected by sod species with rates of atrazine and nitrogen. Agronomy J. 68:250-254.

Berendse, F. (1983). An alternative approach to the analysis of mixed cropping experiments. 1. Estimation of competition effects. Neth. J. Agric. Sci. 31(1):1-12 .

Berendse. F. (1979). Competition between plant populations with different rooting depths. 1. Theoretical considerations. Oecologia. 43(1):19-26.

Berger, A. (1994). Larval migration and pest management of the spotted stem-borer Chilo partellus (Swinhoe) (Lepidoptera; Pyralidae). Intl. J. Pest Mgt. 40:6-12.

Berger, D. A. and D. M. Dabney (1985). Retardation of germination and early growth of corn planted notill in sub cover crop. Proc. Southern Regional No-Till Conf., GA Agric. Expt. Sta., Griffin, GA.

Bergersen, F. J. and G. L. Turner (1972). An evaluation of ${ }^{15} \mathrm{~N}$ methods for estimating nitrogen fixation in a subterranean clover-perennial ryegrass sward. Aust. J. Agric. Res. 34:391-401.

Bergerson, F. J. and G. L. Turner (1983). An evaluation of ${ }^{15} \mathrm{~N}$ methods for estimating nitrogen fixation in a subterranean clover-perennial ryegrass sward. Aust. J. Agric. Res. 34:391-401.

Berkowitz, A. R. (1988). Competition for resources in weed-crop mixtures In Weed Managemment In Agroecosystems: Ecological Approaches (ed: M. A. Altieri and M. Liebman). CRC Press, Boca Raton, FL, pp. 90-119.

Berrentine, W. L. and L. R. Oliver (1977). Competition threshold levels, and control of cocklebur in soybeans. Mississippi Agric. For. Expt. Sta. and Arkansas Agric. Agric. Expt. Sta. Bull. 83.

Best, L. B. (1991). Wildlife use of experimental strip intercropping systems. Sustainable Agric. Res. Educ. (SARE) or Agric. in Concert with the Environ. (ACE) res. proj., 7 pp.

Best, L. B. (1992). Wildlife use of experimental strip intercropping systems. Sustainable Agric. Res. Educ. (SARE) or Agric. in Concert with the Environ. (ACE) res. proj., 9 pp.

Beste, C. E. (1976). Co-cropping sweet corn and soybeans. Hort. Sci. 11:236-238.

Beuerlein, J. E. and H. N. Lafever (1989). Row spacing and seeding rate effects on soft red winter wheat yield, its components and agronomic characteristics. Appl. Agric. Res. 4:106-110.

Bhan, B. M. and M. Singh (1972). Chemical control of weeds in maize + cowpea mixture. Annual Report, Res. Progress, G. B. Pant, Univ. Agric. Technology, Pantnagar, U. P., India. 191 pp. 
Bharambe, D. T. (1983). A note on an index of utility of mixed cropping and allocation of such areas under separate crops: a comment. J. Indian Soc. Agric. Stat. 35(2):154-156.

Bhat, K. S. and K. B. Abdul Khader (1970). Inter- and mixed cropping in arecanut gardens. Indian Farm. $29(3): 35,43$.

Bhat, K. S. and K. B. Abdul Khader (1970). Intercropping of legumes in hybrid maize. Allahabad Farmer 44(1/2):49-53.

Bhat, K. S. and N. M. Nayar (1976). Maximise income from arecanut gardens. Indian Farm. 25(11):2729.

Bhat, T. V. (1973). Mixed cropping: A boon to areca growers. Inten. Agric. 10(3):5-7.

Bhatnagar, V. S. and J. C. Davies (1978). Factors affecting populations of gram pod borer, Heliothis armigera (Hubner) in the period 1974-77 at Patancheru (Andhra Pradesh). Oriental Entomology Workshop on Population Ecology in Relation to Insects of Economic Importance, Bangalore, India.

Bhatnagar, V. S. and J. C. Davies (1978). ICRISAT Cropping Entomology 1977-78 Progress Report 1. Hyderabad, India.

Bhatt, B. S. and U. M. Damor (1985). Relative performance of intercrops at graded levels of fertilizers in maize. Indian J. Agron. 30:514-515.

Bhoj, R. L. and P. C. Kapoor (1970). Intercropping of maize on spring planted sugarcane gives high profits with adequate nitrogen use. Indian J. Agron. 15: 242-246.

Bhola, A. L., O. P. Mehta, H. S. Malik, and T. P. Yadava (1989). Studies on intercropping of Indian mustard with potato. $7^{\text {th }}$ Intl. Rapeseed Congress, pp. 935-939.

Bhowmik, P. C. and J. D. Doll (1982). Corn and soybean response to allelopathic effects of weeds and crop residues. Agron. J. 74:601-606.

Bhowmik, P. C. and J. D. Doll (1984). Allelopathic effects of annual weed residues on growth and nutrient uptake of corn and soybeans. Agronomy J. 76:383-388.

Bhutada, J. C. and K. A. Parashar (1981). Studies on the effect of intercropping and N fertilization on the yield and quality of sugarcane first ratoon. Indian Sugar 31(4):273-279.

Bhuva, H. P., J. S. Katrodia, G. L. Patel, and B. S. Chundawat (1989). Response of intercropping on economics and effects on main crop of mango under South Gujarat conditions. Acta Hort. 231:316320.

Biederbeck, V. O., O. T. Bouman, J. Looman, et al. (1993). Productivity of four annual legumes as green manure in dryland cropping systems. Agronomy J. 85:1035-1043.

Biederdeck, 'V. O., C. A. Campbell, and R. P. Zentner (1984). Effect of crop rotation and fertilization on some biological properties of a loam in southwestern Saskatchewan. Can. J. Soil Sci. 64:355-367.

Biemond, T. (1989). A tomato growth model as part of a bio-economic model. Acta Hort. 260:285-293.

Bin, J. (1983). Utilization of green manure for raising soil fertility in China. Soil Sci. 135:65-69.

Bin-Mohamed, A. and N. S. bin M. Nor (1986). Intercropping of rotan manau (Calamus manan), with rubber (Hevea brasiliensis). Pertanika, Univ. Pertanian Malaysia 9:161-165.

Bingham, S. W. (1983). Annual bluegrass control during overseeding of bermudagrass. Proc. South. Weed Sci. Soc. 36:123-127.

Bingham, S. W., R. E. Schmidt, and C. K. Curry (1969). Annual bluegrass control in overseeded bermudagrass putting green turf. Agronomy J. 61:908-911.

Black, A. L. (1973). Soil property changes associated with crop residue management in a wheat-fallow rotation. Soil Sci Soc. Amer. Proc. 37:943-946.

Black, J. N. (1958). Competition between plants of different initial seed sizes in swards of subterranean clover (Trifolium subterraneum) with particular reference to leaf area and the light microclimate. Aust. J. Agric. Res. 9:299-318.

Black, J. N. (1960). An assessment of the role of planting density in competition of red clover and lucerne in the early vegetative stage. Oikos 11:26-42.

Blackshaw, R. E. (1994). Differential competitive ability of winter wheat cultivars against downy brome. Agonomy J. 86:649-654.

Blackshaw, R. E., E. H. Stobbe, and A. R. W. Sturko (1981). Effects of seeding date and densities of green foxtail (Setaria viridis) on the growth and productivity of spring wheat (Triticum aestivum). Weed Sci. 29:212-217. 
Blaine, M. A., N. W. Buehring, J. G. Hamill, and D. B. Reginelli (1988). Soybean-wheat intercropping response and effect on estimated net returns. Mississippi State Agric. For. Expt. Sta.. Spec. Bull. 88-1, pp. 79-82.

Blanchet, K. M., J. R. George, K. M. Gettle, D. R. Buxton, and K. J. Moore. (1995). Establishment and persistence of legumes interseeded with switchgrass. Agronomy J. 87:935-941.

Bland, B. F. (1967). The effect of cutting frequency and root segregation on the yield of perennial ryegrass-white clover associations. J. Agric. Sci. 69:391-397.

Blaser, R. E. and N. C. Brady (1950). Nutrient competition in plant associations. Agronomy J. 42:128135.

Blaser, R. E., T. Taylor, W. Griffeth, and W. Skrdla (1956). Seedling competition in establishing forage plants. Agronomy J. 48:1-6.

Bleasdale, J. K. A. (1967). Systematic designs for spacing experiments. Expl. Agric. 3:73-85.

Bledsoe, R. P. and S. J. Hadden (1936). Rate of seeding small grains and winter legumes for hay. Georgia Agric. Expt. Sta. Bull. 194.

Blevins, R. L. , J. H. Herbek, and W. W. Frye (1990). Legume cover crops as a nitrogen source for no-till corn and grain sorghum. Agronomy J. 82:769-772.

Blijenburg, J. G. and J. Sneep (1975). Natural selection in a mixture of eight barley varieties, grown in six successive years. 1. Competiton between the varieties. Euphytica 24:305-315.

Bloomberg, J. R., B. L. Kirkpatrick, and L. M. Wax (1982). Competition of common cocklebur (Xanthium pensylvanicum) with soybean (Glycine max). Weed Sci. 30:507-513.

Blum, A. and M. Naveh (1976). Improved water use efficiency in dryland grain sorghum by promoted plant competition. Agronomy J. 68:111-116.

Boateng, M., C. B. Ratchford, and M. Blase (1987). Profitability analysis of a farming system in Africa. Agric. Syst. 24:81-93.

Bodade, V. N. (1964). Mixed cropping of groundnut and jowar. Indian Oilseeds J. 8:227-301.

Boerboom, J. R. (1991). Integrated crop management for cereal/legume production in the Palouse. Dept. Soil Sci. Tech. rept. 91-3, Washington State Univ., Pullman.

Boerma, H. R. (1979). Breeding soybeans for double cropping. Proc. 8th Soybean Seed Res. Conf, Amer. Seed Trade Assoc., Washington, D. C., pp. 57-62.

Bogart, J. E. and J. B. Beard (1973). Cutting height effects on the competitive ability of annual bluegrass (Poa annua L.) Agronomy J. 65:513-514.

Boller, B. C. and J. Nosberger (1987). Symbiotically fixed nitrogen from field-grown white clover and red clover mixed with ryegrass at low levels of ${ }^{15} \mathrm{~N}$ fertilization. Plant Soil 104:219-226.

Boller, B. C. and J. Nosberger (1988). Influence of dissimilarities in temporal and spatial N-uptake on ${ }^{15} \mathrm{~N}$-based estimates of fixation and transfer of $\mathrm{N}$ in ryegrass-clover mixtures. Plant Soil 112:167175.

Bollero, G. A. and D. G. Bullock (1994). Cover cropping systems for the central Corn Belt. J. Prod. Agric.7:55-58.

Bolton, E. F., V. A. Dirks, and J. W. Aylesworth (1976). Some effects of alfalfa, fertilizer, and lime in corn yield on rotations on clay soil during a range of seasonal moisture conditions. Can. J. Soil Sci. $56: 21-25$.

Bolton, E. F., V. A. Dirks, and M. M. McDonnell (1982). The effect of drainage, rotation, and fertilizer on corn yield, plant height, leaf nutrient composition and physical properties of Brookston clay soil in Southwestern Ontario. Can. J. Soil Sci. 62: 297-309.

Bolton, E. V., V. A. Dirks, and W. I. Findlay (1979). Some relationships between soil porosity, leaf nutrient composition and yield for certain crop rotations at two fertility levels on Brookston clay. Can. J. Soil Sci. 59:1-9.

Bookman, P. A. and R. N. Mack (1983). Competition between Bromus tectorum L. and Poa pratensis L.: The role of light. Oecologia 57:406-411.

Boquet, D. J. and C. C. Johnson (1987). Fertilizer effects on yields, grain composition, and foliar disease of doublecrop soft red wheat. Agronomy J. 79:135-141.

Boquet, D. J. and D. M. Walker (1984). Wheat-soybean double-cropping; stubble management, tillage, row spacing, and irrigation. Louisiana Agric Expt. Sta. Bull. 597. 
Boquet, D. J. and S. M. Dabney (1991). Reseeding, biomass, and nitrogen content of selected winter legumes on grain sorghum culture. Agronomy J. 83:144-148.

Boquet, D. J., A. B. Coco, and D. E. Summers (1986). Cropping systems for higher yield. La. Agric. 30:4$5,7$.

Bordovsky, J. P., W. M. Lyle, and J. W. Keeling (1994). Crop rotation and tillage effects on soil water and cotton yield. Agronomy J. 86:1-6.

Borse, R. H. and R. K. Rathod (1983). Studies on planting patterns and intercropping systems in pearl millet. J. Maharashtra Agric. Univ. Pune. 8(3):254-256.

Borse, R. H., G. Harinarayana, and R. K. Rathod (1983). Studies on planting patterns and intercropping systems in pearl millet (Pennisetum americanum, India). J. Maharashtra Agric. Univ. 8:254-256.

Borst, H. L. and J. B. Park (1932). Experiments with growing corn and soybeans in combination. Ohio Agric. Expt. Sta. Bull. 513.

Boster, J. (1983). A comparison of the diversity of Jivaroan gardens with that of the tropical forest (Intercropping). Hum. Ecol. 11:47-68.

Boster, J. (1983). A comparison of the diversity of Jivaroan gardens with that of the tropical forest intercropping. Human Ecol. 11(1):47-68.

Boudreau, M. A. and C. C. Mundt (1992). Mechanisms of alteration in bean rust epidemiology due to intercropping with maize. Phytopathology 82:1051-1060.

Boudreau, M. A. and C. C. Mundt (1994). Mechanisms of alteration in bean rust development due to intercropping, in computer-simulated epidemics. Ecological Applications 4:729-740.

Bourke, O. O. D. (1963). The West African millet crop. Afr. Soils VIII (1):121-132.

Bourke, R. M. (1976). Food crop farming systems used on the Gazelle Peninsula of New Britain. Proc. Papula New Guinea Food Crops Conf. (ed: K. Wilson and R. M. Bourke), Dept. Primary Industry, Port Moresby, Papula New Guinea: pp. 81-101.

Bouton, J. H., F. C. Whitehead, and J. P. De Battista (1989). Tall fescue rhizome production as influenced by bromegrass competition and cutting frequency. Agronomy J. 81:220-223.

Bovey, R. W., V. L. Hauser, and R. E. Meyer (1990). Establishment of kleingrass with annual ryegrass and other cultural treatments. Agronomy J. 82:216-221.

Bowlen, B. and E. O. Heady (1955). Optimum combinations of competitive crops at particular locations. Iowa Agric. Expt. Sta. Res. Bull. 426:376-399.

Bradfield, R. (1972). Maximising food production through multiple cropping systems centered on rice. In Rice, Science snd Man, IRRI, Los Banos, Philippines, pp. 143-163.

Brandt, A. E. (1945). Principles of experimental design applied to long-term rotations. Soil Sci. Soc. Amer. Proc. 10:306-315.

Brasil, S. (1975). II. Plano Nacional de Desenvolvimento: programa de acao do governo para o Nordeste 1975-79. Recife, Sudene, $171 \mathrm{pp}$.

Brasil, S. (1977). Projeto Sertanejo: programa especial de apoio ao desenvolvimento regional da Regiao Semi-Arido. Programa anual de trabalho, Recife, Sudene.

Braun, H. (1973). Shifting cultivation in developing agriculture. FAO/SIDA Regional Seminar on Shifting Cultivation and Soil Conservation in Africa, Ibadan.

Brawand, H. and L. R. Hossner (1976). Nutrient content of sorghum leaves and grain as influenced by long-term crop rotation and fertilzer treatment. Agronomy J. 68:277-280.

Brede, A. D. (1982). Interaction of three turfgrass species. Ph.D. Thesis, Pennsylvania State Univ., College Station.

Brede, A. D. (1992). Cultural factors for minimizing bermudagrass invasion into tall fescue turf. Agronomy J. 84:919-922.

Brede, A. D. and J. L. Brede (1988). Establishment clipping of tall fescue and companion annual ryegrass. Agronomy J. 80:27-30.

Brede, A. D. and J. M. Duich (1984). Establishment characteristics of Kentucky bluegrass-perennial ryegrass turf mixtures as affected by seeding rate and ratio. Agronomy J. 76:875-879.

Brede, A. D. and J. M. Duich (1984). Initial mowing of Kentucky bluegrass-perennial ryegrass seedling turf mixtures. Agronomy J. 76:711-714.

Brede, A. D. and J. M. Duich (1986). Plant interaction among Poa annua, Poa pratensis and Lolium perenne turfgrasses. Agronomy J. 78:179-184. 
Breese, E. L and J. Hill (1973). Regression analysis of interaction between competing species. Heredity 31:181-200.

Bremer, E. (1991). Influence of lentil and wheat on nitrogen availability to a subsequent crop. Ph.D. Thesis, Univ. Saskatchewan.

Brewbacker, J. L. (1993). Tree improvement for agroforestry systems. In Crop Improvement for Sustainable Agriculture (ed: M. B. Callaway and C. A. Francis), Univ. Nebraska Press, Lincoln and London, pp. 132-156.

Briant, A. R. and R. Johns (1940). Cassava investigations in Zanzibar. W. Afr. Agric. 5:404-412.

Brim, C. A. and W. M. Schutz (1968). Inter-genotypic competition in soybeans: II. Predicted and observed performance of multiline mixtures. Crop Sci. 8:735-739.

Brink, G. E. and D. E. Rowe (1993). Growth of white clover clones in monoculture and contrasting bermudagrass swards. Crop Sci. 33:1091-1094.

Brinsfield, R. B. and K. W. Staver (1989). Cover crops: A paragon for nitrogen management. In Ground Water Issues and Solutions in the Potomac River Basin.Chesapeake Bay Region. Natl. Well Water Assoc., Dublin, Ohio, pp. 271- 285.

Brodie, D. A. (1916). The influence of relative area in intertilled and other classes of crops on crop yield. USDA, Washington, D.C, 8 pages.

Brookman, A. J. (1984). The taungya system in south-west Ghana. Soils Bull. FAO, The Organization Issue 53, pp. 183-185.

Brophy, L. S., G. H. Heichel, and M. P. Russelle (1987). Nitrogen transfer from forage legumes to grass in a systematic planting design. Crop Sci. 27:753-758.

Brougham, R. W. (1965). The effect of red clover on the leaf growth of white clover under long spelling during the summer. N. Z. J. Agric. Res.8:859-864.

Brown, B. A., A. M. Decker, N. A. Sprague, et al. (1960). Band and broadcast seeding of alfalfabromegrass in the notheast. Northeast Reg. Publ. 41, Univ. Maryland Agric. Expt. Sta. Bull. A108.

Brown, C. M. (1982). Relay intercropping: planting soybeans in growing wheat has little risk, good payoff. Crops Soils Mag. 34(8):7-8.

Brown, C. M. and D. W. Graffia (1976). Intercropping soybeans and sorghum in oats. Ill. Res. 18(2):3-4.

Brown, H. B. (1935). Effect of soybeans on corn yields. Louisiana Agric. Expt. Sta. Bull. 265, 31 pp.

Brown, J. E., G. A. Lewis, and H. M. Bryce (1986). Influence of black plastic mulch and row covers on the growth and performance of okra intercropped with turnip greens. Proc. Natl. Plast. Congr., Issue 19, pp. 148-157.

Brown, J. E.; G. A. Lewis, E. L. Carden, and R. N. McDaniel (1986). Effects of black plastic mulch and row covers on the growth and performance of eggplant intercropped with mustard greens. Proc. Natl. Plast. Congr., Issue 19, pp. 384-395.

Brown, J. E., W. E. Splittstoesser, and J. M. Gerber (1985). Production and economic returns of vegetable intercropping systems. J. Amer. Soc. Hort. Sci. 110:350-353.

Brown, P. L. (1964). Legumes and grasses in dryland cropping sytems in the northern and central Great Plains: A review. USDA Misc. Publ. 962, Gov. Print. Office, Washington, D. C.

Browning, J. A. and K. J. Frey (1969). Multiline cultivars as a means of disease control. Ann. Rev. Phytopathology 7:355-382.

Brusko, M. (1987). \$10 weed control in no-till beans. New Farm. 9:10-11.

Brust, G. E., B. R. Stinner, and D. A. McCartney (1986). Predation by soil inhabiting arthropods in intercropped and monoculture agroecosystems. Agric. Ecosyst. Environ. 18:145-154.

Bruulsema, T. W. and B. R. Christie (1987). Nitrogen contribution to succeeding corn from alfalfa and red clover. Agronomy J. 79:96-100.

Bryan, W. B. (1985). Effects of sod-seeding legumes on hill land pasture productivity and composition. Agronomy J. 77:901-905.

Bryan, W. B. and M. B. Materu (1987). Intercropping maize with climbing beans, cowpeas and velvet beans. Z. Acker Pflanzenbau 159:245-250.

Bryan, W. B. and S. A. Peprah (1988). Effect of planting sequence and time, and nitrogen on maize legume intercrop yield. Z. Acker Pflanzenbau 161:17-22. 
Buering, N. W., D. B. Regnielli, and M. A. Blaine (1990). Long term wheat and soybean response to an intercropping system. In Conservation Tillage For Agriculture in the 1990's. Proc. 1990 Southern Regional Conserv. Tillage Conf., N. C. State Univ. Spec. Bull. 90-1, Raleigh, pp. 65-68.

Bueselinck, P. R., D. A. Sleper, S. S. Bughrara, and C. A. Roberts (1992). Effect of mono and mixed culture of tall fescue and birdsfoot trefoil on yield and quality. Agronomy J. 84:133-137.

Bugg, R. L., F. L. Wackers, K. E. Brunson, et al. (1991). Cool-season cover crops relay intercropped with cantaloupe: influence on a generalist predator, Geocoris punctipes (Hemiptera: Lygaeidae). J. Econ. Entomol. 84:408-416.

Buhler, D. D. and J. C. Mercurio (1988). Vegetation management and corn growth and yield in untilled mixed-species perennial sod. Agronomy J. 80:454-462.

Bulder, J. M. (1972). Some annotations in relation to intercropping policies. Proc. Conf. Cocoa and Coconuts, Kuala Lumpur, pp. 269-272.

Bulson, H. A. J., R. W. Snaydon, and C. E. Stopes (1990). Intercropping autumn-sown field beans and wheat: effects on weeds under organic farming conditions. The Council 45: 55-62.

Bundy, L. G. and T. W. Andraski (1993). Soil and plant nitrogen availability tests for corn following alfalfa. J. Prod. Agric. 6:200-206.

Bundy, L. G., T. W. Andraski, and R. P. Wolkowski (1993). Nitrogen credits in soybean-corn crop sequences on three soils. Agronomy J. 85:1061-1067.

Bunpromma, K. and B. B. Mabbayad (1978). Effects of plant population density and N fertilization on sorghum-soybean intercrop. Philippines J. Crop Sci. 3:221-227.

Burdon, J. J., R. H. Groves, and J. M. Cullen (1981). Impact of biological control on the distribution and abundance of Chondrilla-Juncea in Southeastern Australia. J. App1. Ecol. 18(3):957-966.

Buresh, R. J. and S. K. Da Datta (1991). Nitrogen dynamics and management in rice-legume cropping systems. Adv. Agron. 45:1-59.

Buresh, R. J., T. T. Chua, E. G. Castillo, S. P. Liboon, and D. P. Garrity (1993). Fallow and Sesbania effects on soil nitrogen dynamics in lowland rice-based cropping systems. Agronomy J. 85:316-321.

Buresh, R. J., T. Woodhead, K. D. Shepard, E. Flordelis, and R. C. Cabangon (1989). Nitrogen accumulation and loss in a mungbean/lowland rice cropping system. Soil Sci. Soc. Amer. J. $53: 477-482$.

Burleigh, J. H. (1973). Strip cropping effect on beneficial insects and spiders associated with cotton in Oklahoma. Environ. Ento. 2:281-285.

Burns, J. C. and J. E. Standeart (1978). Productivity and economics of legume-based vs. nitrogenfertilized grass-based pasture in the United States. In Forage Legumes for Energy-Efficient Animal Production (ed: R. F. Barnes et al.). Proc. Trilateral Workshop, USDA-ARS Natl. Tech. Info. Serv., Springfield, VA, pp. 56-71.

Burns, J. C., L. Goode, H. D. Gross, and A. C. Linnerud (1973). Cow and calf gains on ladino clover-tall fescue and tall fescue grazed alone and with coastal bermudagrass. Agronomy J. 65:877-880.

Burnside, O. C. (1972). Tolerance of soybean cultivars to weed competitiona and herbicides. Weed Sci. 20:294-297.

Burnside, O. C. and R. S. Moomaw (1984). Influence of weed control treatments on soybean cultivars in an oat-soybean rotation. Agronomy J. 76:887-890.

Burnside, O. C. and R. S. Moomaw (1985). Narrow row soybean production in untilled oat stubble. Agronomy J. 77:36-40.

Burnside, O. C., G. A. Wicks, and D. R. Carlson (1980). Control of weeds in oat (Avena sativa)-soybean (Glycine max) ecofarming rotation. Weed Sci. 28:46-50.

Burril, L. C. (1973). Pest control and multiple cropping. Agric. Mechanization in Asia.

Burton, G. W. (1976). Legume nitrogen versus fertilizer nitrogen for warm-season grasses. In Biological N Fixation in Forage-Livestock Systems (ed: C. S. Hoveland). Spec. Publ. 28, ASA, Madison, WI, pp. 55-81.

Burton, J. W., C. A. Brim, and J. O. Rawlings (1983). Performance of non-nodulating and nodulating soybean isolines in mixed culture with nodulating cultivars. Crop Sci. 23:469-473.

Bussell, F. P. (1937). Oats and barley on New York farms. Cornell Ext. Bull. 376.

But, V. P. and T. I. Malykhina (1980). Uzb Biol Zh. Tashkent, "Fan". No. 6. pp. 44-46. 
Butler, G. W. and N. O. Bathurst (1956). The underground transfer of $\mathrm{N}$ from clover to associated grass. Proc. Intl. Grassl. Congr., 7th, 7:168-175.

Buznitskii, A. G. and A. S. Kuzmenko (1975). Uplotnennye posevy kukuruzy: opyt ordena Lenina kolkhoz a im. Zhadanova Mironovskogo raiona Kievskoi oblasti. Moskva: Kolos. 45 pp.

Byerlee, D., M. Iqbal, and K. S. Fischer (1989). Quantifying and valuing the joint production of grain and fodder from maize fields: evidence from northern Pakistan. Expl. Agric. 25:435-445.

Byers, F. A. and W. C. Templeton, Jr. (1988). Effects of sowing date, placement of seed, vegetation supression, slugs and insects upon establishment of no-till alfalfa in orchardgrass sod. Grass Forage Sci. 43:279-289.

Byers, M. E., G. F. Antonious, D. Hilborne, and K. Bishop (1994). Sustainable vegetable culture on erodible lands. Environmentally Sound Agric. Proc. Second Conf., pp. 513-516.

Byers, R. A., W. C. Templeton, Jr., R. L. Mangan, et al. (1985). Establishment of legumes in grass swards: Effects of pesticides on slugs, insects, legume seedling numbers and forage yield and quality. Grass Forage Sci. 40:41-48.

Cable, W. J., J. A. Breen, A. B. Cahusac, et al. (1982). Preliminary results of intercropping Leucaena with taro (Colocasia esculenta) in Western Samoa. Leucaena Res. Rep., Taipei, Taiwan, 3:102-103.

Cadima, Z. A. and D. E. P. Lobao (1982). Alteracoes edaficas provocadas por um sistema de agricultura itinerante em solos de Tabuleiro do Sul da Bahia. Rev. Theobroma. Ilheus 12(4):267-272.

Cady, F. B. (1991). Experimental design and data management of rotation experiments. Agronomy J. 83:50-56.

Cady, F. B. and D. D. Mason (1964). Comparison of fertility treatments in a crop rotation experiment. Agronomy-J. 56:476-479.

Calavan, K. M. and R. R. Weil (1988). Peanut-corn intercrop performance as affected by within-row corn spacing at a constant row spacing. Agronomy J. 80:635-642.

Caldwell, W. D., J. L. Rabb, B. B. Haloubek, and J. S. Frazier (1984). Double cropping irrigated cotton and soybeans with wheat. LA. Agric. 27(3):20-21.

Callaway, M. B. and F. Forcella (1993). Crop tolerance to weeds. In Crop Improvement for Sustainable Agriculture (ed: M. B. Callaway and C. A. Francis), Univ. Nebraska Press, Lincoln and London, pp. 100-131.

Callaway, M. B. and C. A. Francis (1993). Crop Improvement for Sustainable Agriculture. Univ. Nebraska Press, Lincoln.

Cameron, M. M., C. R. Davies, J. Monje, et al. (1994). Comparative activity of phlebotomine sandflies (Diptera: Psychodidae) in different crops in the Peruvian Andes. Bull. Entomological Res. 84:461467.

Camlin, M. S. (1981). Comparative effects between ten cultivars of perennial ryegrass and three cultivars of white clover grown in association. Grass Forage Sci. 36:169-178.

Campbell, C. A., R. P. Zentner, F. Selles, V. O. Biederbeck, and A. J. Leyshon (1992). Comparative effects of grain lentil-wheat and monoculture on crop production, $\mathrm{N}$ economy and $\mathrm{N}$ fertility in a brown chernozem. Can J. Plant Sci. 72:1091-1107.

Campbell, M. (1979). Intercropping with cassava: Proc. Intl. Workshop, Trivandrum, India, Intl. Dev. Res. Centre Ottawa, 142 pp.

Camper, Jr., H. M., C. F. Genter, and K. E. Loope (1972). Double cropping following winter barley harvest in eastern Virginia. Agronomy J. 64:1-3.

Candal-Neto, J. F., C. Vieira, A. A. Cardoso, et al. (1986). Performance of maize varieties at different population densities with three bean varieties in associated cropping, in the state of Espirito Santo. Rev. Ceres 33:51-67.

Capinera, J. L., T. J. Weissling, and E. E. Schweizer (1985). Compatibility of intercropping with mechanized agriculture: effects of strip intercropping of pinto beans and sweet corn on insect abundance in Colorado. J. Econ. Entomol. 78:354-357.

Caradus, J. R., A. C. McKay, J. Van Den Bosch, and D. R. Woodfield (1989). Comparative evaluation of white clover cultivars in spaced plant and small mixed species plot trials. N. Z. J. Agric. Res. 32:433-436.

Carangal, V. R., M. V. Rao, and B. Siwi (1987). Limits imposed by management in irrigated farming systems. Australian Centre Intl. Agric. Res. (ACIAR), pp. 64-71. 
Carberry, P. S., R. L. McCown, R. C. Muchow, et al. (1996). Simulation of a legume ley farming system in northern Australia using the Agricultural Production Systems Simulator. Aust. J. Expl. Agric. 36:1037-1048.

Carcamo, H. A. and J. R. Spence (1994). Crop type effects on the activity and distribution of ground beetles (Coleoptera: Carabidae). Environ. Entomology 23:684-692.

Carew, R. and K. Buckmire-K. (1982). A case study of a small farm system in Grenada. In Case Studies for a Workshop: Res. Crop-Animal Syst., Caribbean Agric. Res. Dev. Inst., pp. 87-104.

Carlson, G. A. and M. C. Marra (1986). Double-cropping wheat and soybeans in the southeast. Input use and patterns of adoption. USDA Agric. Econ. Rep. No. 552, U. S. Gov. Print. Office, Washington, D. C.

Carr, P. M., B. G. Schatz, J. C. Gardner, and S. F. Zwinger (1992). Intercropping sorghum and pinto bean in a cool semiarid region. Agronomy J. 84:810-812.

Carr, P. M., B. G. Schatz, J. C. Gardner, and S. F. Zwinger (1993). Grain yield and returns from intercropping wheat and flax. J. Prod. Agric. 6:67-72.

Carr, P. M., J. C. Gardner, B. G. Schatz, S. W. Zwinger, and S. J. Guldan (1995). Grain yield and weed biomass of a wheat-lentil intercrop. Agronomy J. 87:574-579.

Carsky, R. J., L. Singh, and R. Ndikawa (1994). Suppression of Striga hermonthica on sorghum using a cowpea intercrop. Expl. Agric. 30:349-358.

Carson, A. G. (1976). Weed competition and control in groundnuts (Arachis hypogaea L.). Ghana J. Agric. Sci. 9:169-173.

Carter, Jr., T. E. and H. R. Boerma (1979). Implications of genotype $\times$ planting date and row spacing interactions in double-cropped soybean cultivar development. Crop Sci. 19:606-610.

Casler, M. D. (1988). Performance of orchardgrass, smooth bromegrass, and ryegrass in binary mixtures with alfalfa. Agronomy J. 80:509-514.

Casler, M. D. and P. N. Drolsom (1984). Yield testing cool-season forage grasses in pure stands vs. binary mixtures with alfalfa. Crop Sci. 24:453-456.

Casler, M. D., M. Collins, and J. M. Reich (1987). Location, year, maturity, and alfalfa competition effects on mineral element concentrations in smooth bromegrass. Agronomy J. 79:774-778.

Castellanos, A. E. and D. Martinez (1992). Ecophysiological observations within the Phaseolus coccineus complex. Annul Rep. Bean Improv. Coop., Colorado State Univ., 35:209-210.

Castin, E. M., S. San Antonio, and R. Moody (1976). The effect of different weed control practices on crop yield and weed weight in sole cropped and intercropped corn and mung beans. $7^{\text {th }}$ Annual Conf? Pest Control Council, Philippines, Cagayan de Oro City, Philippines.

Castro, M., H. Pitre, and D. Meckenstock (1988). Potential for using maize as a trap crop for the fall armyworm, Spodoptera frugiperda (Lepidoptera: Noctuidae), where sorghum and maize are intercropped on subsistence farms. Fla. Entomol. 71:273-278.

Catherinet, M. (1965). Note surla culture du macabo et du taro an Cameroun." Agronomie Tropicale 20(8):717-724.

Caviness, C. E. and F. C. Collins (1985). Double cropping. World Soybean Conf. III, Westview Press, Boulder and London.

Caviness, C. E. and K. O'Kelley (1985). Evaluation of soybean cultivars for double cropping with wheat. Arkansas Farm Res. 34(5):3.

Cecilia, F. C. S., M. A. P. Ramalho, and J. C. Garcia (1982). Adubacao nitrogenada e fosfatada na consorciacao milhofejao. Pesqui Agropecu Bras. Brasilia. Agropecuaria 17(9):1285-1291.

Cecilia, F. C. S. and M. A. P. Ramalho (1982). Behavior of dry bean cultivars: monocropping and intercropping with corn (Brazil). Cienc. Prat., Lavras, 6:45-54.

Cenpukdee, U. and S. Fukai (1991). Effects of nitrogen supply on cassava/pigeonpea intercropping with three contrasting cassava cultivars. J. Fert. Use Tech. 29:275-280.

Cervancia, C. R. (1985). Soybean insect diversity in different cropping combinations. Philip. J. Sci. 114:87-100.

Chalk, P. M. and C. J. Smith (1994). 15N isotope dilution methodology for evaluating the dynamics of biologically fixed $\mathrm{N}$ in legume-non-legume associations. Biol. Fertility Soils 17:80-84. 
Challaiah, R. E., O. C. Burnside, G. A. Wicks, and V. A. Johnson (1986). Competition between winter wheat (Triticum aestivum) cultivars and downy brome (Bromus tectorum). Weed Sci. 34:689-693.

Chamberlin, R. J., D. C. I. Peake, R. L. McCown, et al. (1986). Competition for nitrogen between a maize crop and forage legume intercrops in a wet-dry tropical environment. In Potentials of Forage Legumes in Farming Systems of Sub-Saharan Africa (ed: I. Haque et al.). Proc. Workshop ILCA, Addis Ababa, Ethiopia, pp. 82-99.

Chamblee, D. S. (1958). Some above- and below-ground relationships of an alfalfa-orchardgrass mix. Agronomy J. 50:434-437.

Chamblee, D. S. (1972). Relationships with other species in a mixture. In Alfalfa Science and Technology (ed: C. H. Hanson). ASA, Madison, WI, pp. 211-228.

Chamblee, D. S. and M. Collins (1988). Relationships with other species in a mixture. In Alfalfa and Alfalfa Improvement (ed: A. A. Hanson et al.). Agron. Monogr. 29, ASA, CSSA, and SSSA, Madison, WI, pp. 439-457.

Chamblee, D. S. and R. J. Lovvorn (1953). The effect of rate and method of seeding on the yield and botanical composition of alfalfa-orchardgrass and alfalfa-tall fescue. Agronomy J. 45:192-196.

Chan, L. M., R. R. Johnson, and C. M. Brown (1980). Relay intercropping soybeans into winter wheat and spring oats. Agronomy J. 72:35-39.

Chandel, A. S., K. N. Pandey, and S. C. Saxena (1989). Symbiotic nitrogen fixation and nitrogen benefits by nodulated soybean (Glycine max (L.) Merrill) to interplanted crops in northern India. Trop. Agric. 66:73-77.

Chandini, S., G. R. Pillai, and C. Sreedharan (1982). Crude protein and crude fibre content of fodder grasses as influenced by legume intercropping and phosphorus application. Agric. Res. J. Kerala 20:68-71.

Chandler, P. (1994). Adaptive ecology of traditionally derived agroforestry in China. Human Ecol. 22:415-442.

Chandra, S. (1978). Monoculture, mixed cropping and rotations: implications for Fiji agriculture field crops, root crops. Fiji Agric. J. 40(2):63-70.

Chandrapanya, D. and G. Banta (1982). Cropping systems research in Thailand multiple cropping, intercropping systems. Rep. Workshop Crop. Syst., IRRI, pp. 295-316.

Chandrapanya, D., T. Charoenwatana, A. Pookpakdi, and G. Banta (1982). Cropping systems research in Thailand (Multiple cropping, intercropping systems). Rep. Workshop Cropping Sys. Res. Asia, IRRI, pp. 295-316.

Chandrasekharan, N. R., S. V. Muhammad, P. Sivasubramanian, et al. (1974). Mixed cropping with sesamum. Madras Agric. J. 61(8):510-515

Chandravanshi, B. R. (1975). Study on intercropping sorghum (Sorghum bicolor (L) Moench) under uniform and paired row planting system. Jawaharlal Nehru Krishi Viswa Vidyalaya Res. J. 9:2426.

Chandravanshi, B. R. (1978). Intercropping in sorghum in Malwa Plateau. Indian Farmer 28(1):13, 22.

Chang, H. I. (1981). Lin Yeh Ko Chi Tung Hsun For Sci Technol. Peiking, Chung-kuo Li n Yeh. K'o Hs'ueh Yen Chiu Y'uen, K'o chi ch'ing Pao Yen Chin So. No. 5, pp. 9-12.

Chang, H., C. H. Chang, and F. W. Ho (1969). Competition between sugarcane and intercrops for fertilizer tagged $\mathrm{p}^{32}$ and $\mathrm{Rb}^{86}$. J. Agric. Assoc. China 63:43-49.

Chang, J. F. and R. M. Shibles (1985). An analysis of competition between intercropped cowpea and maize. II. The effect of fertilization and population density. Field Crops Res. 12:145-152.

Chang, J. F. and R. M. Shibles (1985. An analysis of competition between intercropped cowpea and maize. I. Soil $\mathrm{N}$ and $\mathrm{P}$ levels and their relationships with dry matter and seed productivity. Field Crops Res. 12:133-143.

Chang, X. C. and N. G. Juma (1996). Impact of crop rotations on microbial biomass, faunal populations, and plant $\mathrm{C}$ and $\mathrm{N}$ in a Gray Luvisol (Typic cryoboralf). Biol. Fertility Soils 22:31-39.

Chao, C-K. (1975). Improvements for increasing the cropping intensity of paddy fields in Taiwan in the past five years. In Proc. Cropping Systems Workshop, IRRI, Los Banos, Philippines. pp. 219-230.

Chao, C. C. and T. C. Chuang (1979). Taipei, Chung-kuo nung yeh hua hsueh hui. J. Chin. Agric. Chem. Soc. 17(1/2):10-22. 
Chaparro, C. J., L. E. Sollenberger, and C. S. Jones, Jr. (1992). Limpograss sod management and aeschynomene seed reserve effects on legume reestablishment. Agronomy J. 84:195-200.

Chapman, A. L. and R. J. K. Myers (1987). Nitrogen contributed by legumes to rice grown rotation on the Cununurra soils of the Ord irrigation area, Western Australia. Aust. J. Expt. Agric. 27:155-163.

Chapman, S. R., R. W. Allard, and J. Adams (1969). Effect of planting rate and genotypic frequency on yield and seed size in mixtures of two wheat varieties. Crop Sci. 9:575-576.

Charles, A. H. (1965). Interactions of grass, clover and nurse crop in the seeding year. J. Br. Grassl. Soc. 20:241-247.

Charoen, S. U. (1985). Effects of crop proportion, nitrogen, plant density, cowpea cultivars and water in intercropped rice and cowpeas. M. S. Thesis, Univ. Philippines, Los Banos.

Charreau, C. (1974). Systems of cropping in the dry tropical zone of West Africa with special reference to Senegal. In Proc. Farming Systems Workshop. ICRISAT, Hyderabad, India. pp. 443-468.

Chatterjee, B. N. and B. K. Mandal (1992). Present trends in research on intercropping. Indian J. Agric. Sci. 62:507-518.

Chatterjee, B. N. and D. C. Ghosh (1978). Fertilier application in intercropping of sugarcane and wheat with potato under West Bengal conditions. Fert. News. 23(10):36-37.

Chatterjee, B. N. and K. K. Bhattacharyya (1987). Food legumes under cropping systems in India. Australian Centre Intl. Agric. Res. (ACIAR), pp. 232-233.

Chatterjee, B. N. and M. A. Roquib (1976). Soybean in multiple and intercropping. Indian J. Genet Plant Breed. 35(2):264-268.

Chauhan, D. S. and A. S. Faroda (1979). Studies on intercropping of pasture legumes with Cenchrus ciliaris grass. Forage Res. 5(1):79-80.

Chauhan, D. S. and V. P. S. Tomar (1981). Effect of intercropping of cowpea on the forage production and quality of anjan grass, Cenchrus ciliaris, for sheep rearing. Forage Res. 7(1):77-81.

Chauhan, R. (1987). Management of insect pests in chickpea. Australian Centre Intl. Agric. Res. (ACIAR), pp. 288-289.

Chee, J. K. and C. C. Wong (1986). Forages in Malaysia. Australian Centre Intl. Agric. Res. (ACIAR), pp. 84-88..

Chee, Y. K. (1974). Intercropping with groundnuts and maize in rubber small holdings. Proc. Prim. Planters Conf. Rubber Res. Inst., Malaya, pp. 93-101.

Chellamuthu, V. and S. Purushothaman (1983). Relative planting time of onion (CO 2) as intercrop in cotton (MCU 9) under two systems of planting. Madras Agric. J. Coimbatore 70:775-780.

Chen, Y. S., B. T. Kang, and F. E. Caveness (1989). Alley cropping vegetable crops with Leucaena in southern Nigeria. HortSci. 24:839-840,

Cheng, C. (1972). Multiple cropping practices on paddy fields in Taiwan. Food \& Fert. Tech. Gent., Ext. Bull. 15.

Chengappa, P. G. and N. S. P. Rebello (19??). An economic analaysis of intercropping in coffee estates of Coorg. J. Indian Hortic. 25(4): 154-157.

Chenna Rayudu, K. C. and P. B. Parthasarathy (1972). Mixed cropping in rainfed groundnut in Cuddapah district of Andhra Pradesh. Farm. Fact. 7(1):26-30.

Chestnutt, D. M. B. (1970). Interactions of grass species grown in mixtures to the presence of white clover at various levels of applied nitrogen. Record Agric. Res., Northern Ireland 18:43-54.

Chetty, C. K. R. (1983). Research on intercropping systems in drylands. A review of decade's work (1971-72 to 1980-81). All India Coordinated Res. Proj. Dryland Agric., Hyderabad, 124 pp.

Chetty, C. K. R. and M. N. Reddy (1984). Analysis of intercrop experiment in dryland agriculture. Expl. Agric. 20:31-40.

Chetty, C. K. R. and U. M. Rao (1979). Experimental design for intercropping systems and analysis of data. Proc. Intl. Workshop on Intercropping, ICRISAT, Hyderabad, India, pp. 277-281.

Chevrette, J. E., L. P. Folkins, F. M. Gauthier, and J. E. R. Greenshields (1960). Evaluation of birdsfoot trefoil. I. Compatability of Lotus corniculatus L. with other legumes and grasses. Can. J. Plant Sci. 40:259-266.

Childs, P. C. and R. E. Breen, Jr. (1980). Jojoba intercropping systems costs and returns. Jojoba Happenings. Tucson, Office Arid Lands Studies, Univ. Arizona. p. 8-10. 
Chingaipe, T. M. (1985). Early growth of Eucalyptus camaldulensis under agroforestry conditions at Mafiga, Morogoro, Tanzania. For. Ecol. Mgt. 11:241-244.

Choomuang, M. (1988). A method of analysis of intercropping experiments. Ph.D. Thesis, Univ. Western Australia.

Chopra, C. L. and N. S. Subba Rao (1967). Mutual relationship among bacteroids, leghaemoglobin and nitrogen content of Egyptian clover (Trifolium alexandrinum) and gram (Cicer arietinum). Archives Microbiology 58:71-76.

Chou, C. H. (1988). Effects of pasture-forest interaction in Taiwan. In Global Perspectives on Agroecology and Sustainable Agricultural Systems. Proc. Sixth Intl. Sci. Conf. Intl. Fed. Organic Agric. Movements, Univ. California, pp. 327-336.

Chowdhury, M. K. and E. L. Rosario (1992). Phosphorus utilization efficiency as affected by component population, rhizobial inoculation and applied nitrogen in maize/mungbean intercropping. Expl. Agric. 28:255-263.

Chowdhury, M. K. and E. L. Rosario (1993). Nitrogen utilization efficiency as affected by component populations in maize-mungbean intercropping. Trop. Agric. 70:199-204.

Chowdhury, M. K. and E. L. Rosario (1994). Comparison of nitrogen, phosphorus and potassium utilization efficiency in maize/mungbean intercropping. J. Agric. Sci. 122:193-199.

Chowdhury, M. S. (1981). Nodulation and symbiotic nitrogen fixation in legumes under mixed cropping systems. Intl. Symp. Nitrogen Fixation. Curr. Perspect. Nitrogen Fix., Canberra, Australia, p. 469.

Chowdhury, P. C. and R. Bose (1983). Intercropping soybean with pre-kharif maize in the rainy season and feasibilty of a rabi crop in winter on rainfed subtemperate region in the hills of West Bengal (Grain yields, soil moisture, soybeans, India). Indian Agric. 27:229-239. -

Christie, E. K. and J. K. Detling (1982). Analysis of interference between 3 carbon pathway and 4 carbon pathway grasses in relation to temperature and soil nitrogen supply. Ecology 63(5):1277-1284.

$\mathrm{Chu}, \mathrm{H}$. T. (1984). Contributory applied research in growing soybean in the Mekong Delta-Socialist Republic of Vietnam. Soybean Genet. Newsl. 11:169-170.

Chuang, T. C. and M. P. Kuo (1978). Nung Hsueh Yuan, Kuo-li Chung Hsing Ta hsueh. J. Agric. For. 27:173-184.

Chui, J. A. N. and R. Shibles (1983). Influence of spatial arrangement of maize on performance of an associated soybean intercrop. Field Crops Res. 8:187-198.

Chujo, H. and H. Daimon (1984). Plant growth and fate of nitrogen in mixed cropping, intercropping and crop rotation. I. Growth acceleration of some temperate grasses in early stage of mixed cropping with red clover, Trifolium pratense, orchardgrass, Dactylis glomerata, Italian ryegrass, Lolium multiflorum, tall fescue, Festuca arundinacea. Jap. J. Crop Sci. 53:213-221.

Chuo, S. K. and P. C. Leong (1980). A study of the possibility of intercropping chyesim (Brassica chinensis) Chinese cabbage with tomato (Lycopersicum esculentum) and the seasonal effect on their yields in Singapore. J. Primary Ind. 8(2):91-102.

Churchill, B. R. (1947). Productiveness of bromegrass strains from different regions when grown in pure stands and in mixture with alfalfa in Michigan. J. Amer. Soc. Agron. 39:750-761.

Churchill, H. (1993). Forestry with Populus deltoides. South African For. J. 167:63-66.

CIAT (1978-1982). Cassava production systems. Annual Report, Centro Internacional de Agricultura Tropical, Cali, Columbia

CIMMYT (1974). The Puebla project: Seven years of experiments 1967-1973. El Batan, Mexico. $116 \mathrm{pp}$.

Ciotti, A. and A. Cavallero (1980). Haymaking losses in cocksfoot, lucerne and a cocksfoot-lucerne mixture in relation to conditioning and degree of drying at harvest. In Forage Conservation in the 80 's (ed: C. Thomas). Occasional Symp. no. 11, Br. Grassl. Soc., London, UK. pp. 214-220.

Claassen, M. M. and D. E. Kissel (1984). Rotation with soybeans increases corn and grain sorghum yields. Better Crops Plant Food 68:28-30.

Clapp, Jr., J. G. (1974). Overseeding small grain in standing soybeans vs. conventional planting. Agronomy J. 66:463-465.

Clark, A. J. (1993). Managing hairy vetch/rye cover crop mixtures for nitrogen and water in no-tillage corn. Ph.D. Thesis, Univ. Maryland, College Park.

Clark, A. J., A. M. Decker, and J. J. Meisinger (1994). Seeding rate and date kill effects on hairy vetchcereal rye cover crop mixtures for corn production. Agronomy J. 86:1065-1070. 
Clark, A. J., A. M. Decker, J. J. Meisinger, and M. S. McIntosh (1997). Kill date of vetch, rye, and a vetch-rye mixture: I. Cover crop and corn nitrogen. Agronomy J. 89:427-434.

Clark, A. J., A. M. Decker, J. J. Meisinger, and M. S. McIntosh (1997). Kill date of vetch, rye, and a vetch-rye mixture: II. Soil moisture and corn yield. Agronomy J. 89:434-441.

Clark, A. J., A. M. Decker, J. J. Meisinger, F. R. Mulford and M. S. McIntosh (1995). Hairy vetch kill date effects on soil water and corn production. Agronomy J. 87:579-585.

Clark, E. A. (1979). Corn and bean interactions in mixed culture. Final Report AID Grant No. AID/ta-G1435, PIO/T no. 3177757.

Clark, E. A. and C. A. Francis (1985). Bean maize intercrops: a comparison of bush and climbing bean growth habits. Field Crops Res. 10:151-166.

Clark, E. A. and C. A. Francis (1985). Transgressive yielding in bean:maize intercrops; interference in time and space. Field Crops Res. 11:37-53.

Clark, J. D. (1971). The Prehistory of Africa. Praeger Publ., New York.

Clark, K. M., W. C. Bailey, and R. L. Myers (1995). Alfalfa as a companion crop for control of Lygus lineolaris (Hemiptera: Miridae) in amaranth. J. Kansas Entomological Soc. 68:143-148.

Clark, M. S. and S. H. Gage (1996). Effects of free-range chickens and geese on insect pests and weeds in an agroecosystem. Amer. J. Alternative Agric. 11:39-47.

Clason, T. (1996). Timber-pasture management enhances productivity of loblolly pine plantations. Louisiana Agric. 39(2):14-16.

Clason, T. R. (1994). Forage intercropping enhances productivity of loblolly pine plantations. Proc. Soc. Amer. Foresters Natl. Convention, pp. 245-248.

Claude, P. P. A. F. MacKenzie, B. E. Coulman, and G. R. Mehuys (1993). Effet du labour printanier et des cultures intercalaires de trefle rouge sur le rendement du mais-grain. Can. J. Plant Sci. 73:3746.

Clegg, M. D. (1982). Effect of soybean on yield and nitrogen response of subsequent sorghum crops in eastern Nebraska. Field Crops Res. 5:233-239.

Clement, A., F. P. Chalifour, M. P. Bharati, and G. Gendron (1992). Effects of nitrogen supply and spatial arrangement on the grain yield of a maize/soybean intercrop in a humid subtropical climate. Can. J. Plant Sci. 72:57-67.

Clement, A., F. P. Chalifour, M. P.Bharati, and G. Gendron 1992). Nitrogen and light partitioning in a maize/soybean intercropping system under a humid subtropical climate. Can. J. Plant Sci. 72:6972.

Coaker, T. H. (1990). Intercropping for pest control. The Council 45: 71-76.

Coale, F. J. and J. H. Greene (1990). Root distribution and shoot development in no-till full-season and double-crop soybean. Agronomy J. 82:606-612.

Coble, H. D. and R. L. Ritter (1978). Pennsylvania smartweed (Polygonum pensylvanicum L.) interference in soybeans (Glycine max). Weed Sci. 26:556-559.

Coble, H. D., F. M. Williams, and R. L. Ritter (1981). Common ragweed (Ambrosia artemisiifolia) interference in soybeans (Glycine max). Weed Sci. 29:339-342.

Cochran, V. L. and S. F. Schlentner (1995). Intercropped oat and fababean in Alaska: Dry matter production, dinitrogen fixation, nitrogen transfer, and nitrogen fertilizer response. Agronomy J. 87:420-424.

Cochran, W. G. (1939). Long term agricultural experiments. J. Royal Statistical Soc., Ser. B, 6:104-148.

Coffman, C. B. and J. R. Frank (1992). Corn-weed interactions with long-term conservation tillage management. Agronomy J. 84:17-21.

Coffman, W. R. (1977). Rice varietal development for cropping systems at IRRI. Symp. Cropping Systems Res. Dev. Asian Rice Farmer. IRRI, Los Banos, Philippines, pp. 359-371.

Cohen, D. and Z. Raanan (1983). The production of the freshwater prawn Macrobrachium rosenbergii in Israel. III. Density effect of all-male Tilapia hybrids on prawn yield characters in polyculture. Aquaculture 35(1):57-71.

Coll, M. and D. G. Bottrell (1994). Effects of nonhost plants on an insect herbivore in diverse habitats. Ecology 75:723-731.

Coll, M. and D. G. Bottrell (1996). Movement of an insect parasitoid in simple and diverse plant assemblages. Ecol. Entomology 21:141-149. 
Collins, M. (1985). Wetting effects on the yield and quality of legume and legume-grass hays. Agronomy J. 77:936-941.

Conn, J. S. (1987). Effects of tillage and cropping sequence on Alaskan weed vegetation: Studies on land under cultivation for eleven years. Soil Tillage Res. 9:265-274.

Connell, J. H. (1983). On the prevalence and relative importance of interspecific competition: Evidence from field experiments. Amer. Nat. 122:661-696.

Connell, J. H. (1990). Apparent versus "real"competition in plants. In Perspectives on Plant Competition (ed. J. B. Grace and D. Tilman), Academic Press, Dan Diego, CA, pp. 9-25.

Connell, M. J., R. J. Raison, and P. K. Khanna (1995). Nitrogen mineralization in relation to site history and soil properties for a range of Australian forest soils. Biol. Fertility Soils 20:213-220.

Conniff, K., C. J. De-Mooy, and D. W. Burke (1986). Effects of genotype, plant spacing and intercropping with sorghum on ashy stem blight of cowpeas. Annu. Rep. Bean Improv. Coop., Geneva, N.Y, 29:97.

Connolly, J. (1986). On difficulties with replacement-series methodology in mixture experiments. J. Appl. Ecol. 23:125-137.

Connolly, J. (1987). On the use of response models in mixture experiments. Oecologia 72:95-103.

Connolly, J. (1988). What is wrong with replacement series? Trends Ecol. Evol. 3:24-26.

Connolly, J., P. Wayne, and R. Murray (1990). Time course of plant-plant interactions in experimental mixtures of annuals: Density, frequency and nutrient effects. Oecologia 82:513-526.

Coolman, R. M. and G. D. Hoyt (1993). Increasing sustainability by intercropping. HortTech. 3:309-312.

Cooper, J. (1968). A statistical analysis for data from an experiment involving all possible pairs of $p$ varieties applied to mixtures of 8 bean varieties. M. S. Thesis, Cornell Univ., Ithaca.

Copeland, P. J. and R. K. Crookston (1992). Crop sequence affects nutrient composition of corn and soybean grown under high fertility. Agronomy J. 84:503-509.

Copeland, P. J., R. R. Allmaras, R. K. Crookston, and W. W. Nelson (1993). Corn-soybean rotation effects on soil water depletion. Agronomy J. 85:203-210.

Cordero, A. (1977). Principles of intercropping: Effects of nitrogen fertilization and row arrangement on growth, nitrogen accumulation and yields of corn and interplanted understory annuals. Ph.D. Thesis, North Carolina State Univ., Raleigh.

Cordero, A. and R. E. McCollum (1978). Intercropping research in North Carolina. Agronomic-Economic Res. on Soils in the Tropics, Annual Report, 1976-77, North Carolina State Univ., Raleigh, pp. 181-200.

Cordero, A. and R. E. McCollum (1979). Yield potential of interplanted food crops in southeastern U. S. Agronomy J. 71:834-842.

Costello, M. J. (1994). Broccoli growth, yield and level of aphid infestation in leguminous living mulches. Biol. Agric. Hort. 10:207-222.

Costello, M. J. (1995). Spectral reflectance from a broccoli crop with vegetation or soil as background: influence on immigration by Brevicoryne brassicae and Myzus persicae. Entomologia Expt. Appl. 75:109-118.

Coultas, C. L., T. J. Post, J. B. Jones, Jr., and Y. P. Hsieh (1996). Use of velvet bean to improve soil fertility and weed control in corn production in northern Belize. Comm. Soil Sci. Plant Analysis 27:2171-2196.

Cousens, R. (1985). An empirical model relating crop yield to weed and crop density and statistical comparison with other models. J. Agric. Sci. (Camb.) 105:513-521.

Cousens, R. (1991). Aspects of the design and interpretation of competition (interference) experiments. Weed Tech. 5:664-673.

Cousens, R., P. Brain, J. T. O'Donovan, and P. A. O'Sullivan (1987). The use of biologically realistic equations to describe the effects of weed density and relative time of emergence on crop yield. Weed Sci. 35:720-725.

Couto, L., J. M. Gomes, D. Binkley, et al. (1995). Intercropping eucalypts with beans in Minas Gerais, Brazil. Intl. Tree Crops J. 8:83-93.

Cowell, L. E., E. Bremer, and C. Van Kessel (1989). Yield and $\mathrm{N}_{2}$ fixation of pea and lentil as affected by intercropping and N application. Can. J. Soil Sci. 69:243-251. 
Cowling, D. W. and D. R. Lockyer (1967). A comparison of the reaction of different grass species to fertilizer nitrogen and to growth in association with white clover: II. Yield of nitrogen. J. Br. Grassl. Soc. 22:53-61.

Cox, F. R. and E. Uribe (1992). Management and dynamics of potassium in a humid tropical ultisol under a rice-cowpea rotation. Agronomy J. 84:655-660.

Cox, F. R. and E. Uribe (1992). Potassium in two humid tropical ultisols under a corn and soybean cropping system: I. Management. Agronomy J. 84: 480-484.

Crabtree, R. J. and G. A. Makonnen (1980). Double and mono-cropped wheat and grain sorghum under different tillage and row spacings. Soil Sci. 132:213-219.

Crabtree, R. J. and R. N. Rupp (1980). Double and monocropped wheat and soybeans under different tillage and row spacings. Agronomy J. 72:445-449.

Crabtree, R. J., J. D. Prater, and P. Mbolda (1990). Long term wheat, soybean, and grain sorghum doublecropping under rainfed conditions. Agronomy J. 82:683-686.

Crabtree, R. J., R. G. Greenland, J. D. Prater et al. (1987). Mono- and double-cropped wheat and soybeans under rain-fed and irrigated conditions Soil Sci. 144:53-60.

Crabtree, R. J., R. G. Greenland, S. O. Mehdawi, and P. L. Claypool (1986). Mono- and double-cropped wheat and grain sorghum under rainfed and irrigated conditions. Agronomy J. 78:986-990.

Craig, L. A., W. J. Wiebold, and M. S. McIntosh (1981). Nitrogen fixation rates of alfalfa and red clover in mixture with grasses. Agronomy J. 73:996-998.

Cramer, C. and K. Cicero (1992). 2 crops for the price of 1: intercropping grosses up to \$332/A. New Farm. 14(2):14-17.

Creerria, R. P. (1979). Intercropping coconut with cacao. Philippine J. Coconut Studies 4(4):29-35.

Crocioni, A. (1951). Rilievi sulla consociazione della patata con girassole e granoturco e sulle reciproche influenze fra le plante consociate. Annali della Sperimentazione Agraria 5:441-451.

Crookston, R. K. (1976). Intercropping-- a new version of an old idea. Crop Sci. 28:7-9.

Crookston, R. K. (1982). Field studies on the yield effect of corn and soybeans in rotation - are plant growth regulators involved? Proc. Plant Growth Regul. Soc. Amer. 9:137-143.

Crookston, R. K. and D. S. Hill (1979). Grain yields and land equivalent ratios from intercropping corn and soybeans in Minnesota. Agronomy J. 71:41-44.

Crookston, R. K. and J. E. Kurle (1989). Corn residue effect on the yield of corn and soybean grown in rotation. Agronomy J. 81:229-232.

Crookston, R. K., J. E. Kurle, P. J. Copeland, et al. (1991). Rotational cropping sequence affects yield of corn and soybean. Agronomy J. 83:108-113.

Crowther, F. and W. G. Cochran (1942). Rotation experiments with cotton in the Sudan Gezira. J. Agric. Sci. 32:390-405.

Cruse, M. C., I. C. Anderson, and F. B. Ames, Jr. (1984). Residual effects of corn and soybeans on subsequent corn crop. Proc. World Soybean Res. Conf. III, Westview Press, Inc., Boulder, CO, pp. 1061-1065.

Cruse, R. M. (1991). Strip intercropping rotations. The Service 1417:59-62.

Cruse, R. M. (1992). Strip intercropping rotations. Iowa State Univ. Coop. Ext. Serv., The Service, 1467:39-44.

Cruse, R. M., M. Ghaffarzadeh, and J. B. Swan (1995). Strip intercropping. Clean water, clean environment, $21^{\text {st }}$ century: team agriculture, working to protect water resources. Conf. Proc. Kansas City, pp. 73-75.

Cudney, D. W., L. S. Jordan, and A. E. Hall (1991). Effect of wild oat (Avena fatua) infestations on light interception and growth rate of wheat (Triticum aestivum). Weed Sci. 39:175-179.

Cullen, N. A. (1964). Species competition in establishing swards: Suppression effects of ryegrass establishment and production of associated grasses and clovers. N. Z. J. Agric. Res. 7:678-693.

Cullen, N. A. (1967). Lucerne-grass establishment and management. In The Lucerne Crop (ed: R. H. M. Langer), A. H. and A. W. Reed Publ., Wellington, New Zealand, pp. 186-190.

Cummins, D. G. (1973). Interplanting corn, sorghum, and soybeans for silage. Georgia Expt. Sta. Res. Bull. 150., Experiment, GA.

Cunningham, R. K. and J. C. Burridge (1960). The growth of cacao (Theobroma cacao) with and without shade. Ann. Bot. 24:458-462. 
Curl, E. A. (1963). Control of plant diseases by plant rotation. Bot. Rev. 29:413-479.

Curran, B. S., K. D. Kephart, and E. K. Twidwell (1993). Oat companion crop management in alfalfa establishment. Agronomy J. 85:998-1003.

Dabholkar, A. R. and G. S. Lal (1983). Maximise your profits by intercropping jowar (Gross income, Madhya Pradesh, India). Indian Farming 33:41, 43-44.

Dabney, S. M., E. C. McGawley, D. J. Boethel, and D. A. Berger (1988). Short-term rotation systems for soybean production. Agronomy J. 80:197-204.

Dabney, S. M., G. A. Breitenbeck, J. L. Griffin, and B. J. Hoff (1989). Subterranean clover cover crop used to increase rice yield. Agronomy J. 81:483-487.

Dabney, S. M., J. D. Schreiber, C. S. Rothrock, and J. R. Johnson (1996). Cover crops affect sorghum seedling growth. Agronomy J. 88:961-970.

Dagg, M. (1965). A rational approach to the selection of crops for areas of marginal rainfall. E. Afr. Agric. For. J. 30(3):292-300.

Dahlan, M. M. (1981). Evaluation of corn (Zea mays L.) genotypes in monoculture and intercropped with a cereal and a legume. Ph.D. Thesis, Cornell Univ.

Dahniya, M. T., A. Jalloh, and H. C. Ezumah (1994). Intercrop yields of cassava and rice as influenced by cassava variety and population. Acta Hort. 380:194-199.

Dai, C. Y. and X. Y. Huang (1982). Chiang Su Nung Yeh Hseuh Jiangsu Nongye Kexue Jiangsu. Agric. Sci. 11:30-34.

Daimon, H. and H. Chujo (1986). Plant growth and fate of nitrogen in mixed cropping, intercropping and crop rotation. IV. Residual effect of some legumes on nitrogen content of suceeding crops. Jap. J. Crop Sci. 55:299-305.

Daimon, $H$. and $H$. Chujo (1986). Plant growth and fate of nitrogen in mixed cropping, intercropping and crop rotation. II. Nitrogen content of wheat in association with pea or broad bean. Jap. J. Crop Sci. 55:162-170.

Daimon, H. and H. Chujo (1986). Plant growth and fate of nitrogen in mixed cropping, intercropping and crop rotation. III. Nitrogen content of corn in association with soybean, cowpea or kidney bean. Jap. J. Crop Sci. 55:171-178.

Dakore, M. G. and A. M. Mungikar (1988). Spatial arrangement in maize-cowpea intercropping for fodder. Geobios 15:38-40.

Dakshindas, D. G. (1975). Intercropping of potato in sugarcane. Proc. Golden Jubilee 1925-75 of the Sugar Technologistics Assoc. of India. $5^{\text {th }}$ : Ag-57-Ag-61.

Dalal, R. C. (1974). Effects of intercropping maize with pigeon pea on grain yield and nutrient uptake. Expl. Agric. 10:219-224.

Dalal, R. C. (1974). Effects of intercropping maize with pigeon peas on grain yield and nutrient uptake. Expl. Agric. 10:219-224.

Dalal, R. C. (1977). Effect of intercropping maize with soya bean on grain yield. Trop. Agric. 54(2):189191.

Dale, J. E. and J. M. Chandler (1979). Herbicide-crop rotation for johnsongrass (Sorghum halpense) control. Weed Sci. 27:479-485.

Dalrymple, D. F. (1971). Survey of Multiple Cropping in Less Developed Nations. Foreign Econ. Dev. Serv., USDA, USAID, Washington, D. C.

Damodaran, A. and S. Sankaran (1974). A note on evaluation of herbicides in cereal-legume mixtures. Madras Agric. J. Coimbatore 61:924-925.

Dangler, J. M., S. J. Locascio, and S. K. Ohair (1985). Biomass production by cassava as affected by fertilizer rate and cowpea intercrop. Proc. Soil Crop Sci. Soc. Fla., The Society 44:116-118.

Daniels, M. B. and H. D. Scott (1991). Water use efficiency of double-cropped wheat and soybeans. Agronomy J. 83:564-570.

Danso, A. A. and P. Morgan (1993). Alley cropping maize with cassia in Gambia: Crop production and soil fertiluty. Agrofor. Syst. 21:133-147.

Danso, S. K. A., F. Palmason, and G. Hardarson ( 1993). Is nitrogen transferred between field crops? Examining the question through a sweet-blue lupine (Lupinus angustifolius L.)-oats (Avena sativa) intercrop. Soil Biol. Biochem. 25:1135-1137. 
Danso, S. K. A., F. Palmason, and G. Hardarson (1993). Is nitrogen transferred between field crops? Examining the question through a sweet-blue lupin (Lupinus angustifolius L.) oats (Avena sativa) intercrop. Soil Biol. Biochem. 25:1135-1137.

Danso, S. K. A., F. Zapata, G. Hardarson, and M. Fried (1987). Nitrogen fixation in fababeans as affected by plant population density in sole or intercropped systems with barley. Soil Biol. Biochem. 19:411415.

Dao, T. H. (1987). Crop residues and management of annual weeds in continuous no-till wheat (Triticum aestivum). Weed Sci. 35:395-400.

Dar, H. U. and V. Kaul (1986). Agroforestry: a possible way out to the increasing human predicament. J. Trop. For. 2:177-182.

Dart, P. J., R. Islam, and A. Eaglesham (1975). The root nodule symbiosis of chickpea and pigeonpea. Proc. Intl. Workshop on Grain Legumes, ICRISAT, Hyderabad, India, pp. 63-83.

Das, P. K. and B. N. Chatterjee (1977). Nitrogen economy in forage production through grass and legume mixed cropping maize and deenanath grass (Pennisetam pedicellatum Trin.) with cowpea (Vigna sinensis Eindlicher) and rice bean (Vigna umbellate Thunb.) . Indian J. Agron. 22(4):240-246.

Das, R. B. and N. Venkat Reddy (1982). Intercropping of Leucaena with grain crops. Leucaena Res. Rep. Taipei, Taiwan. 3:23-24.

Dash, A. N., H. Mahapatra, A. C. Pradhan, and N. C. Patnaik (1987). Effect of mixed and intercropping on the occurrence of some pests in Orissa. Environ. Ecol. 5:526-530.

Daulay, H. S. (1980). Intercropping system for drylands. Symp. Arid Zone Res. Dev., Scientific Publishers, Jodhpur, India, pp. 229-237.

Daulay, H. S., A. K. Chakravarty, and G. N. Bhati (1972). Intercropping of rainy-season legumes in Cenchrus ciliaris L. and Lasiurus sindicus henr. pastures in the arid zone of Rajasthan. Indian J. Agric. Sci. 42(2):148-151.

Dauro, D. and M. A. Mohamed-Saleem (1995). Shoot and root interactions in intercropped wheat and clover. Trop. Agric. 72:170-172.

Davis, F. L. (1949). The Old Rotation at Auburn. Alabama Reprint DD-8-49. Amer. Potash Inst., Inc., Washington, D. C.

Davis, J. F. (1942). The effect of sweet clover green manure on crop yields on heavy soils in Michigan. Soil Sci. Soc. Amer. Proc. 6:290-293.

Davis, J. G., A. Manu, L. R. Hossner, and N. Persaud (1994). Phosphorus management of a millet/cowpea intercrop system on sandy dunal soils of western Niger. J. Plant Nutrition 17:899-910.

Davis, J. H.C. (1979). Interacciones de genotipos por sistema de cultivo en frijol y maiz. Curso de Frijol, CIAT, Cali, Colombia.

Davis, J. H. C. and S. Garcia (1983). Competitive ability and growth habit of indeterminate beans and maize for intercropping. Field Crops Res. 6:59-75..

Davis, J. H. C., L. van Beuningen, M. V. Ortiz, and C. Pino (1984). Effect of growth habit of beans on tolerance to competition from maize when intercropped. Crop Sci. 24:751-755.

Davis, J. H. C., M. C. Amesquita, and J. E. Munoz (1981). Border effects and optimum plot sizes for climbing beans (Phaseolus vulgaris) and maize in association and in monoculture. Exp. Agric. 17:127-135.

Davis, R. I. and J. F. Brown (1996). Epidemiology and management of kava dieback caused by cucumber mosaic cucumovirus. Plant Dis. 80:917-921.

Davis, R. R. (1958). The effect of other species and mowing height on the persistence of lawn grasses. Agronomy J. 50:671-673.

Day, B. E. (1978). The status and future of chemical weed control. In Pest Control Strategies (ed: E.H. Smith and D. Pimenter). Academic Press, New York, pp. 203-213.

Daynard, T. B., M. Tollenaar, T. J. Vyn, et al. (1985). Rye-corn sequences for biomass production. First Rep. Eng. Stat. Inst., Contract File \#23SU-01916-ER23, Agric. Canada, Ottawa.

Ddungu, J. C. M. (1987). Regional needs for banana and plantain improvement in Eastern Africa. Australian Centre Intl. Agric. Res. (ACIAR), pp. 36-38.

De R. and S. Singh (1981). Management practices for intercropping systems. Workshop on Intercropping, ICRISAT, Hyderabad, India. 
De Sapir, O. L. (1969). Agriculture and Diola society. In African Food Production Systems: Cases and Theory (ed. P. F. M. McLoughlin). Johns Hopkins Univ. Press, Baltimore, pp. 192-227.

De Silva, N. T. M. H. and M. de S. Liyange (1978). An appraisal of linear programming in planning intercropping. Agric. Agroind. J. 11(4):3-7.

de Wit, C. T. (1961). Space relationships within poplations of one or more species. In Symposium of Society for Experimental Biology. XV. Mechanisms in Biological Competition. Academic Press, New York, pp. 314-329.

de Wit, C. T. (1960). On competition. Vers. Landbouw. Ondezoekingen. 665 Wageningen, 82 pp.

de Wit, C. T. (1961). Space relationships within populations of one or more species. In Symposium of Society for Experimental Biology. XV. Mechanisms in Biological Competition. Academic Press, New York, pp. 314-329.

de Wit, C. T. (1965). Photosynthesis of crop canopies. Agric. Res. Rep. No. 663. Univ. Wageningen, Pudoc, Wageningen, The Netherlands.

De Wit, C. T. (1970). On the modelling of competitive phenomena. Proc. Adv. Study Inst. Dynamics Numbers Popul., PUDOC, Wageningen, Netherlands, pp. 269-281.

de Wit, C. T. and J. P. van den Bergh (1965). Competition among herbage plants. Neth. J. Agric. Sci. 13:212-221.

de Wit, C. T., P. G. Two, and G. L. Ennik (1966). Competition between legumes and grasses. Verslages Landbou.

De, R. (1974). Prospects for crop intensification and diversification in rainfed areas in Southeast Asia. FAO/UNDP Intl. Expert Consultation on the Use of Improved Technology for Food Production in Rainfed Areas of Tropical Asia, Khon Kaen, Thailand.

De, R. and R. C. Gautam (1987). Management practices to increase and stabilize pearl millet production in India. Proc. Intl. Pearl Millet Workshop, ICRISAT, pp. 247-253.

De, R., R. S. Gupta, S. P. Singh, et al. (1978). Interplanting maize, sorghum and pearl millet with short duration grain legumes. Indian J. Agric. Sci. 48(3):132-140.

De-Mastro, G., V. Marzi, and A. Ventrelli (1993). Influence of temporary intercropping on the productivity of liquorice (Glycyrrhiza glabra L.). Acta Hort. 344:523-528.

Dear, K. B. G. and R. Mead (1984). Testing assumptions and other topics in bivariate analysis. Statistics in Intercropping Tech. Rep. No. 2, Dept. Applied Statistics, Reading Univ.

Dear, K. G. B. and R. Mead (1983). Statistics in intercropping: The use of bivariate analysis techniques for the presentation, analysis and interpretation of data. Tech. Rep. 1, Dept. Applied Statistics, Univ.'Reading, England.

Deat, M., G. Sement, and P. Fontenay (1977). Influence de deux precedents culturaux sur l'enherbament de la culture cotonuiere subsequente. Cotton et Fibres Tropical 32:229-232.

Deat, M., G. Sement, and P. Fontenay (1978). Role of the preceding crops on weed infestation of the cotton plot of a crop rotation. Paper, Intl. Weed Sci. Conf., Ibadan, Nigeria.

Debuck, J. (1978). In which locations may we renounce intercropping? Dlg Mitt Dtsch Landwirtsch Ges. 93(13):774, 776, 778.

Decker, A, M., H. J. Retzer, and F. R. Dudley (1974). Cool-season perennials vs. cool-season annuals sodseeded into a bermudagrass sward. Agronomy J. 66:381-383.

Decker, A. M. and R. F. Dudley (1976). Minimum tillage establishment of five forage species using five sod-seeding units and two herbicides. Proc. Intl. Symp. Morgantown, W. Va., pp. 140-145.

Decker, A. M., A. J. Clark, J. J. Meisinger, F. R. Mulford, and M. S. McIntosh (1994). Legume cover crop contributions to no-tillage corn production. Agronomy J. 86:126-135.

Defelice, M. S., W. W. Witt, and J. R. Martin (1987). Johnsongrass (Sorghum halepense) control and soil moisture relationships in no-tillage, doublecropped soybean (Glycine max). Weed Sci. 35:108-114.

DeLoach, C. J. (1970). The effect of habitat diversity on predation. Proc. Tall Timbers Conf. Ecology, Animal Control by Habitat Management 2. pp. 223-241.

Dempster, J. P. and T. H. Coaker (1974). Diversification of crop ecosystems as a means of controlling pests. In Biology in Pest and Disease Control (ed: Price Jones). Wiley, New York.

Denamany, G. and N. B. B. Hamid (1979). Coconut intercropping systems in Peninsular Malaysia. Oleagineux Rev. Int. Corps. Gras. Paris, SETCO. 34(1):7-13. 
Denver, C. E. (1984). Effects of intensive green manure cropping on restoring soil productivity for cotton. Proc. Beltwide Cotton Prod. Res. Conf., Natl. Cotton Council Amer., Memphis, TN.

Depuis, G. (1983). Influence of nitrogen fertilizer and row spacing of companion crop harvested as forage on the establishment of alfalfa. Can. J. Plant Sci. 63:443-452.

Desai, N. D. and S. N. Goyal (1980). Intercropping of sesame with other oilseed crops. Indian J. Agric. Sci. 50(8):603-605.

Desai, S. N. and P. G. Bhoi (1982). Assessment of production potential of food and forage under agroforestry system intercropping. J. Maharashtra Agric. Univ. Pune. 7(1):33-36.

Deshmukh, R. B. and D. G. Bhapkar (1982). Constraints and the opportunities in pulse production in western Maharashtra. In Pulse Production, Constraints and Opportunities: Proc. Symp. on Increasing Pulse Production in India - (ed: H.C. Srivastava. et al.), New Delhi, pp. 185-192.

Deshpande, P. M. and J. T. Nankar (1977). Effect of intercropping on yield of seasonal sugarcane and on net returns in Marathwada region. Indian Sugar 27(5):261-263.

Devos, P. and G. F. Wilson (1979). Intercropping of plantains with food crops: maize, cassava and cocoyams. Paris: Inst. de Recherches sur les Fruits et Agrumes. 34(3):169-174.

Devos, P. and G. F. Wilson (1983). Associations du plantain a k'autres plantes vivrieres. II. Autres combinaisons avec le mais, le taro et le manioc. Paris: Inst. de Recherches sur les Fruits et Agrumes. 38(4):293-299.

Devotta, A. D. and S. R. Chowdappan (1975). A note on mixed cropping in dryland cotton. Madras Agric. J. Coimbatore 62(4):234-236.

Devotta, A. D. and S. R. Chowdappan (1976). Mixed cropping of cotton with legumes and non-legumes in black cotton soils of Tamil Nadu. Madras Agric . J. Coimbatore 63(4):249-250.

Dey, N. R., A. K. Ghosh, and M. Joshi (1958). Intercropping of sorghum with legumes. Allahabad Farmer 32:240-241.

Dhileepan, K. (1991). Insect pests of intercrops and their potential to infest oil palm in an oil-palm-based agroforestry system in India. Trop. Pest Mgt. 37:57-58.

Dhillon, G. S. and A. S. Walia (1980). Studies on groundnut-clusterbean association intercropping. J. Res. Punjab Agric. Univ. Ludhiana 17(1):34-37.

Dhillon, G. S. and D. S. Kler (1981). Sugarcane summer pulses association studies. Indian J. Ecol. 8(1):55-59.

Dhoble, M. V. and V. S. Khuspe (1983). Studies on intercropping in sugarcane. Indian Sugar 33(4):255258.

Dhuri, A. V., K. M. Singh, and R. N. Singh (1986). Effect of intercropping on population dynamics of insect pests of black gram, Vigna mungo (L.) Hepper. Indian J. Entomol. 48:329-338.

Di Prima, G., B. Lo Cascio, and R. Sarno (1975). Relationship between plant population and lay to yield of forage corn and Vigna sinensis cowpeas intercropping. Riv. Agron. 9(2/3):111-116.

Diaz, A. C., B. M. Jose-Rios, and J. R. Antonio (1983). Evaluation of different systems of corn-beans arrangements in the east part of Antioquia State (Intercropping, Colombia). Rev. Inst. Colomb. Agropecu. 18:251-259.

Dick, W. A. (1984). Influence of long-term tillage and crop rotation combinations on soil enzyme activities. Soil Sci. Soc. Amer. J. 48:569-574.

Dick, W. A. and D. M. Van Doren, Jr. (1985). Continuous tillage and rotation combination effects on corn, soybean, and oat yields. Agronomy J. 77:459-465.

Dick, W. A., D. M. Van Doren, Jr., G. B. Triplett, Jr., and J. E. Henry (1986). Influence of long-term tillage and rotation combinations on crop yields and selected soil parameters: I. Results obtained for a Mollic Ochraqualf soil. II. Results obtained for a Fragiudalf soil. Res. Bull. 1180 and 1181, Ohio Agric. Res. Dev. Ctr., Ohio State Univ., Wooster.

Dick, W. A., E. L. McVoy, W. M. Edwards, and R. Lal (1991). Continuous application of no-tillage to Ohio soils. Agronomy J. 83:65-73.

Dickens, R. (1979). Control of annual bluegrass (Poa annua) in overseeded bermudagrass (Cynodon spp.) golf greens. Weed Sci. 27:642-644.

Dickey, E. C., T. R. Peterson, J. R. Gilley, and L. N. Miekle (1983). Yield comparisons between continuous no-till and tillage rotations. Trans. ASAE 26:1682-1686. 
Dickinson, J. C. (1972). Alternatives to monoculture in the humid tropics of Latin America. Trop. Georgr. $24: 217-222$

Dijkstra, J. and A. L. F. de Vos (1972). The evaluation of selections of white clover (Trifolium repens L.) in monoculture and in mixture with grass. Euphytica 21:432-439.

Dillon, J. E. and McKibben, G. E., (1972). Double crop and play summer roulette. Illinois Res. 14(1):6-7.

Dillon, J., D. L. Plucknett, and G. Vallaeys (1978). The review of farming systems research at the International Agricultural Research Centers CIAT, IITA, ICRISAT and IRRI. Rome: FA0. 57 pp.

Dissanayake, S. N. and U. P. de S. Waidyanatha (1987). The performance of some tropical forage grasses interplanted with young Hevea trees and their effect on growth of the rubber. Trop. Agric. 64:119121.

Ditsch, D. C. and M. M. Alley (1991). Non luguminous cover crop management for residual N recovery and subsequent crop yields J. Fert. Issues 8:6-13.

Divekar, C. B. (1960). Behavior of Jayadhar cotton when grown as intercrop with groundnut. Mysore Agric. J. 35:202-215.

Dobbs, S. H. and C. Borthick (1995). Cultural control practices. Oklahoma State University, OSU Ext. Facts, 4 pp.

Dobson, J. W., C. D. Fisher, and E. R. Beaty (1976). Yield and persistence of several legumes growing in tall fescue. Agronomy J. 68:123-125.

Doll, E. C. and L. A. Link (1957). Influence of various legumes on the yields of succeeding corn and wheat and nitrogen content of the soil. Agronomy J. 49:307-309.

Donald, C. M. (1951). Competition amongst pasture plants at increasing density. Aust. J. Agric. Res. 2:355-376.

Donald, C. M. (1958). The interaction of competition for light and for nutrients. Aust. J. Agric. Res. 9:421-435.

Donald, C. M. (1961). Competition for light in crops and pastures. Symp. Soc. Expl. Biol. 15:282-313.

Donald, C. M. (1963). Competition among crop and pasture plants. Adv. Agron. 15-1-118..

Donald, L. (1970). Food production by the Yalunka household Sierra Leone. In African Food Production Systems Cases and Theory (ed. P. F. M. McLoughlin). John Hopkins Univ. Press, Baltimore, pp. 165-191.

Dorais, M., A. Gosselin, and M. J. Trudel (1988). Growing systems for greenhouse tomato production under high photosynthetic photon flux density supplemental lighting. Acta Hort. issue 230:405412.

Doran, J. W. and W. S. Smith (1991). Role of cover crops in nitrogen recycling. In Cover Crops For Clean Water (ed: W. L. Hargrove). Soil Water Conserv. Soc., Ankney, Iowa, pp. 85-90.

Dovel, R. L., M. A. Hussey, and E. C. Holt (1990). Establishment and survival of Illinois bundleflower interseeded into an established kleingrass pasture. J. Range Mgt. 43:153-156.

Dover, J. W. (1986). The effect of labiate herbs and white clover on Plutella xylostella oviposition. Entomol. Expl. Appl. 42:243-247.

Doyle, C. J., J. Evans, and J. Rossiter (1986). Agroforestry: an economic appraisal of the benefits of intercropping trees with grassland in lowland Britain. Agric. Syst. 21:1-32.

Drolsom, P. N. and D. Smith (1976). Adapting species for forage mixtures. In Multiple Cropping (ed: R. I. Papendick et al.). ASA, Madison, WI, pp. 223-232.

Drury, C. F., J. A. Stone, and W. I. Findlay (1991). Microbial biomass and soil structure associated with corn, grasses, and legumes. Soil Sci. Soc. Amer. J. 55:805-811.

Dubbs, A. L. (1971). Competition between grass and legume species on dryland. Agronomy J. 63:359362.

Dubbs, A. L. (1975). Performance of grasses, legumes, and mixtures on dryland in central Montana as measured by species competition, yield, and quality. Montana Agric. Expt. Sta. Bull. 683.

Duckham, A. N. and G. B. Masefield (1911). Farming Systems of the World. Chatto and Windus, London.

Duffield, S. J. (1994). Trichogramma egg parasitism of Helicoverpa armigera on short-duration pigeonpea intercultured with sorghum. Entomologia Expt Applicata 72:289-296.

Duguma, B., B. T. Kang, and D. U. U. Okali (1988). Effect of pruning intensities of three woody leguminous species grown in alley cropping with maize and cowpea on an Alfisol. Agrofor. Syst. 6:19-36. 
Dumont, R. (1970). Types of Rural Economy: Studies in World Agriculture. Methuen and Co, Ltd, London.

Dunavin, Jr., L. S. (1987). Comparison of turnip-cabbage hybrid, rape, and rye, alone and in combination with annual ryegrass and crimson clover. Agronomy J. 79:591-594.

Dunavin, L. S. (1982). Vetch and clover overseeded on a bahiagrass sod. Agronomy J. 74:793-796.

Dunavin, L. S. (1990). Cool-season forage crops seeded over with dormant rhizoma peanut. J. Prod. Agric. 3:112-114.

Dunavin, L. S. (1992). Florigraze rhizoma peanut in association with warm-season perennial grasses. Agronomy J. 84:148-151.

Duncan, S. R. and W. T. Schapaugh, Jr. (1993). Row orientation and planting pattern of relay intercropped soybean and wheat. J. Prod. Agric. 6:360-364.

Duncan, S. R., W. T. Schapaugh, Jr., and J. P. Shroyer (1990). Relay intercropping soybeans into wheat in Kansas. J. Prod. Agric. 3:576-581.

Dunleavy, J. M. and C. R. Weber (1967). Control of brown stem rot of soybeans with corn-soybean rotations. Phytopathology 57:114-117.

Dunn, J. H., D. D. Minner, B. F. Fresenberg, and S. S. Bughrara (1994). Bermudagrass and cool-season turfgrass mixtures: Response to simulated traffic. Agronomy J. 86:10-16.

Dusad, L. R. and D. K. Morey (1980). Effect of intercropping sorghum with legumes on yield, economics and nitrogen economy. J. Maharashtra Agric. Univ. Pune. 4(3):314-316.

Dwivedi, G. K. (1985). Evaluation of Setaria varieties at different levels of nitrogen under intercropping systems. Indian J. Agron. 30:231-234.

- Dwivedi, G. K., K. C. Kanodia, and N. C. Sinha (1991). Significance of intercropped range legumes in nitrogen economy, biomass potential and protein enrichment of Chrysopogon fulvus. Trop. Agric. 68:255-258.

Dwivedi, G. K., N. C. Sinha, P. S. Tomer, and O. P. Dixit (1988). Nitrogen economy, biomass production and seed production potential of Chrysopogon fulvus by intercropping of pasture legumes. Z. Acker Pflanzenbau 161:129-134.

Dyke, G. V. (1988). Changes with time of crop yield in a long-term experiment. J. Agric. Sci. (Camb.) 111:317-332.

Eadie, A. G., C. J. Swanton, J. E. Shaw, and G. W. Anderson (1992). Integration of cereal cover crops in ridge-tillage corn (Zea mays) production. Weed Tech. 6(3):553-560.

Eagles, C. F. (1972). Competition for light and nutrients between natural populations of Dactylisis glomerata. J. Appl. Ecol.7:141-151.

Eaglesham, A. R. J. and D. L. Eskew (1981). Improving the nitrogen nutrition of maize by intercropping with cowpea. Soil Biol. Biochem. 13(2):169-171.

Eaglesham, A. R. J., A. Ayanaba, V. R. Rao, and D. L. Eskew (1981). Improving the nitrogen nutrition of maize by intercropping with cowpea. Soil Biol. Biochem. 13:169-171.

Eagleton, G. E. (1991). A comparison of moisture-conserving practices for the traditional sorghum-based cropping system of the Bay Region, in Somalia. Agric. Ecosyst. Environ. 36:87-99.

Eason, W. R., H. F. Tomlinson, and C. Hainsworth (1992). Effect of ground vegetation on root distribution of ash trees. Aspects Appl. Biol. 29:225-231.

Eaton, B. J., K. C. Feltner, and O. G. Russ (1973). Venice mallow competition in soybeans. Weed Sci. 21:89-94.

Eaton, B. J., O. G. Russ, and K. C. Feltner (1976). Competition of velvetleaf, prickly sida, and Venice mallow in soybeans. Weed Sci. 24:224-228.

Ebelhar, S. A., W. W. Frye, and R. L. Blevins (1984). Nitrogen from legume cover crops for no-tillage corn. Agronomy J. 76:51-55.

Eberhart, S. A., L. H. Penny, and G. F. Sprague (1964). Intra-plot competition among maize single crosses. Crop Sci. 4:467-471.

Eckert, D. J. (1988). Rye cover crops for no-tillage corn and sorghum production. J. Prod. Agric. 1:207210.

Edje, O. T. (1981). Response of sorghum Sorghum bicolor and beans Phaseolus vulgaris cultivar 253-1 in monoculture and in association. Luso J. Sci. Technol. 2(1):3-13. 
Edje, O. T. and L. K. Mughogho (1979). Seed, energy and protein yield in maize and bean association. Mixed cropping. Malawi Annu. Rep. Bean Improv. Coop. 2(2):28-30.

Edje, O. T., L: K. Mughogho, and Y. P. Rao (1976). Effects of mixed cropping of maize and beans on seed yield. Annu. Rep. Bean Improv. Coop. 19:31-34.

Edwards, C. A., G. E. Brust, B. R. Stinner, and D. A. McCartney (1992). Work in the United States on the use of cropping patterns to promote natural enemies of pests. Aspects Applied Biol. 31:139-148.

Edwards, D. C. (1941). Possibility of establishment of grass under maize. E. Afr. Agric. For. J. 6:233-235.

Edwards, D. G., H. A. H. Sharifuddin, M. N. M. Yusoff-M-N-M., et al. (1991). The management of soil acidity for sustainable crop production. Dev. Plant Soil Sci. 45:383-396.

Edwards, J. H., D. L. Thurlow, and J. T. Eason (1988). Influence of tillage and crop rotation on yields of corn, soybean, and wheat. Agronomy J. 80:76-80.

Edwards, L. M. and J. M. Sadler (1992). Relationships between cover performance and date of fallseeding where winter rye was broadcast into a standing potato crop. Can. J. Plant Sci. 72:269-274.

Effendi, S. (1979). Cassava intercropping patterns and management practices in Indonesia. Rice or corn. Ottawa, Intl. Dev. Res. Centre, pp. 35-36.

Effendi, S. (1985). Improvement of smallholder rubber farming productivity in Indonesia. Australian Centre Intl. Agric. Res. (ACIAR), pp. 108-113.

Egger, K. and B. Martens (1987). Theory and methods of ecofarming and their realization in Rwanda, East Africa. In The Green Revolution Revisited: Critique and Alternatives (ed: B. Glaeser), pp. 150-175.

Egunjobi, O. A. (1984). Effects of intercropping maize with grain legumes and fertilizer treatment on populations of Pratylenchus brachyurus Godfrey (Nematoda) and on the yield of maize (Zea mays L.). Prot. Ecol. 6:153-167.

Einhellig, F. A. and J. A. Rasmussen (1989). Prior cropping with grain sorghum inhibits weeds. J. Chem. Ecol. 19:369-375.

Ekpete, D. M. (1976). Fertilizer response under mixed cropping in Nsukka. Nigeria. E. Afr. Agric. For. J. 42(1):18-27.

Ekshinge, B. S., V. B. Shelke, and V. G. Musande (1983). Correlation and path coefficient analysis in sorghum and pigeon pea grown in intercropping system (Sorghum bicolor, Cajanus cajun, genetics). J. Maharashtra Agric. Univ. 8:45-47.

El-Hout, N. M. and A. M. Blackmer (1990). Nitrogen status of corn after alfalfa in 29 Iowa corn fields. J. Soil Water Conserv. 45:115-117.

El-Swaify, S. A., A. Lo, R. Joy, et al. (1988). Achieving conservation-effectiveness in the tropics using legume intercrops. Soil Technol. 1:1-12.

El-Tobgy, H. E. (1974). Contemporary Egyptian Agriculture. Beirut, Lebanon.

Elabbadi, K., M. Ismaili, and L. A. Materon (1996). Competition between Medicago truncatula and wheat for 15N labeled soil nitrogen and influence of phosphorus. Soil Biol. Biochem. 28:83-88.

Eldani, A. and J. H. Primavera (1981). Effect of different stocking combinations on growth, production and survival of milkfish (Chanos chanos Forskal) and prawn (Penaeus monodon Fabricius) in polyculture in brackishwater ponds. Aquaculture 23(114):59-72.

Ellern, S. J., J. L. Herpes, and G. K. Segar (1970). A comparative study of the distribution of roots of Avena fatua and $A$. strigosa in mixed stands using a C14-labelling technique. J. Ecol. 58:865-868.

Ellet, W. B., H. H. Hill, and W. G. Harris (1915). The effect of the association of legumes and nonlegumes. Virginia Agric. Expt. Sta. Tech. Bull. 1:28-36.

Elmore, C. D., M. A. Brown, and E. P. Flint (1983). Early interference between cotton Gossypium hirsutum and 4 weed species. Weed Sci. 31(2):200-207.

Elmore, R. W. and J. A. Jackobs (1984). Yield and yield components of sorghum and soybeans of varying plant heights when intercropped. Agronomy J. 76:561-564.

Elmore, R. W. and J. A. Jackobs (1986). Yield and nitrogen yield of sorghum intercropped with nodulating and nonnodulating soybeans. Agronomy J. 78:780-782.

EMBRAPA (1976). Sistemes de producao para milho e feijo. Parana-Regiao de Oeste e Sudaese, ENCARSE, SE, Circular no. 119.

EMBRAPA (1977). Sistemes de producao para milho e feijao. Parana-Regiao de Norte Pioneiro, ACARPA, PR, Beletim no. 20. 
Emebiri, L. C. and J. C. Obiefuna (1992). Effects of leaf removal and intercropping on the incidence and severity of black Sigatoka disease at the establisment phase of plantains (Musa spp. AAB). Agric. Ecosyst. Environ. 39:213-219.

Emmond, G. S. and R. J. Ledingham (1972). Effects of crop rotation on some soil-borne pathogens of potato. Can. J. Plant Sci. 52:605-611.

Endersby, N. M. and W. C. Morgan (1991). Alternatives to synthetic chemical insecticides for use in crucifer crops. Biol. Agric. Hort. Intl. J. 8:33-52.

England, F. (1968). Competition in mixtures of herbage grasses. J. Appl. Ecol. 5:227-242.

Engle, R. E. (1973). Influence of nitrogen fertilization on species dominance in turfgrass mixtures. Proc. Int. Turfgrass Res. Conf., ASA and CSSA, Madison, WI, pp.104-111.

Ennik, G. C. (1960). Competition between white clover and perennial ryegrass with differences in light intensity and moisture supply. Jaarbook Inst. Biologisch Scheitundig Onderzuck Handbouwnwigewiesson, Wageningen. pp. 37-50.

Enyi, B. A. C. (1973). Effects of intercropping maize or sorghum with cowpeas, pigeon peas and beans. Expl. Agric. 9:83-90.

Erbach, D. C. and W. G. Lovely (1976). Machinery adaptions for multiple cropping. In Multiple Cropping (ed. R. I. Papendick et al.), ASA Spec. Publ. 27, ASA, Madison, WI, pp. 337-346.

Erney, D. (1996). Long live the three sisters. Organic Gardening 43:37-40.

ERS. (1965). Agriculture of Northern Africa. Washington D.C. Economic Res. Serv., U.S.D.A.

Esmail, S. H. M. (1991). Benefits of intercrops as feed sources for livestock. Rangelands 13:193-195.

Etheridge, W. C, and C. A. Helm (1924). Corn and soybeans. Missouri Agric. Sta. Bull. 220. 23 pp.

Ethirajan, A. S., A. Misra, and M. Lal (1981). Intercropping Bengalgram with sugarcane (Chickpeas). Indian Sugar 31:525-527.

Eussen, J. H. H. (1979). Some competition experiments with Alang alang Imperata cylindrica in replacement series. Oecologia 40(3):351-356.

Evangelio, L. A. and E. L. Rosario (1981). Effect of different cropping systems on the growth and yield of sweet corn and sweet-potato. Ann. Trop. Res. 3(4):289-300.

Evans, A. C. (1960). Studies of intercropping. Part I. Maize or sorghum with groundnuts. E. Afr. Agric. For. J. 26:1-10.

Evans, A. C. (1962). Soil fertility studies in Tanganyika. III: On the Kikuyu and Lusoni soil types of the lake and western regions. E. Afr. Agric. For. J. 28:231-239.

Evans, A. C. and A. Sreedharan (1962). Studies of intercropping. Part II. Castorbean with groundnuts or soybeans. E. Afr. Agric. For. J. 28:7-8.

Evans, D. R., J. Hill, T. A. Williams, and I. Rhodes (1985). Effects of coexistence on the performance of white clover-perennial ryegrass mixtures. Oecologia 66:536-539.

Evans, E. M. and D. G. Sturkie (1974). Winter legumes can help supply nitrogen needs, Highlights Agric. Res. 21(2). AL Agric. Expt. Sta., Auburn Univ.

Evans, P. T. and J. S. Rombold (1984). Paraiso (Melia azedarach var. "Gigante") woodlots: an agroforestry alternative for the small farmer in Paraguay. Agroforestry Syst. 2:199-124.

Evans, T. R. (1986). Management of forages to optimise animal production. CSIRO-Div.-Tropical-CropsPastures- St-Lucia-Qld-Australia. Australian Centre Intl. Agric. Res. (ACIAR), pp. 147-151.

Evanylo, G. K. (1991). Rye nitrogen recycling for corn and potato production. In Cover Crops for Clean Water (ed:W. L. Hargrove). Soil Water Conserv. Soc., Ankeny, Iowa, pp. 101-103.

Evenson, J. P., D. L. Plucknett, and I. Horton (1973). A proposed classification for agricultural systems. Proc. Second Intl. Symp. Tropical Root and Tuber Crops, pp. 63-69.

Evers, G. W. (1985). Forage and nitrogen contributions of arrowleaf and subterranean clovers overseeded on bermudagrass and bahiagrass. Agronomy J. 77:960-963.

Ewing, R. P. (1988). Subsoiling and cover crop effects on corn growth and yield. M. S. Thesis, North Carolina State Univ., Raleigh, NC.

Ewing, R. P., M. G. Wagger, and H. P. Denton (1991). Tillage and cover crop management effects on soil water and corn yield. Soil Sci Soc Amer. J. 55:1081-1085.

Exner, D. N. (1992). On-farm research and demonstration of ridge tillage for sustainable agriculture. Sustainable Agric. Res. Educ. (SARE) or Agric. in Concert with the Environ. (ACE) res. proj., 34 pp. 
Ezueh, M. I. and A. T. Taylor (1984). Effects of time of intercropping with maize on cowpea susceptibility to three major pests (Maruca testulalis, Cydia ptychora, Megalurothrips sjostedti). Trop. Agric. 61:82-86, 156.

Ezumah, H. C., N. K. Nam, and P. Walker (1987). Maize-cowpea intercropping as affected by nitrogen fertilization. Agronmy J. 79:275-280.

F.A.O (1966). Production Yearbook, FAO, Rome. 763 pp.

F.A.O (1973). World census of agriculture. 1960. V. Analysis and international comparison of results. $240 \mathrm{pp}$.

F.A.O (1974). Production Yearbook. 327 pp.F.A.O. Rome (1957). Shifting cultivation. Tropical Agric. $34: 159-164$

F.A.O. Rome (1971). 1970 Food Production Year Book. FAO, Rome.

F.A.O. Rome (1972). Improvement and production of maize, sorghum and millett. First FAO/SIDA Training Centre.

Fagbamiye, A. I. (1977). Investigations of traditional mixed cropping and intercropping systems in the tropics. Ph.D. Thesis Univ. Ibadan.

Fahad, A. A., L. N. Mielke, A. D. Flowerday, and D. Swartzendruber (1982). Soil physical properties as affected by soybean and other cropping sequences. Soil Sci. Soc. Amer. J. 46:377-381.

Fairey, D. T. and L. P. Lefkovitch (1991). Establishing perennial legume seed stands with annual companion crops. J. Appl. Seed Prod. 9:49-54.

Faleiros, R. R. S., W. J. Melo, M. A. B. Kanesiro, and E. P. Gasparin (1977). Effects of intercropping of Sorghum bicolor (L.) Moench and Dolichos lablab and of the date of dolichos planting on the contents of soluble proteins. Cientifica. 5(1):26-30.

Fales, S. L. and R. J. Hoover (1990). Chemical regulation of alfalfa/grass mixtures with imazethapyr. Agronomy J. 82:5-9.

Fargette, D. and C. Fauquet (1988). A preliminary study on the influence of intercropping maize and cassava on the spread of African cassava mosaic virus by whiteflies. Aspects Appl. Biol. Issue 17, pp. 195-202.

Faris, M. A. and A. S. S. Arcovere (1983). Yield stability in intercropping studies of sorghum or maize with cowpea or common bean under different fertility levels in northeastern Brazil, Can. J. Plant Sci. 63(4):789-799.

Faris, M. A., H. A. Burioty, O. V. D. Reis, and R. C. Mafra (1983). Intercropping of sorghum Sorghum bicolor or maize Zea mays with cowpeas Vigna unguiculata or common beans Phaseolus vulgaris under two fertility regimes in Northeastern Brazil. Expl. Agric. 19(3):251-262.

Faris, M. A., M. R. A. de Araujo, M. D. A., Lira, and A. S. S. Arcovere (1983). Yield stability in intercropping studies of sorghum Sorghum bicolor or maize Zea mays with cowpea Vigna unguiculata or common bean Phaseolus vulgaris under different fertility levels in Northeastern Brazil. Can. J. Plant Sci. 63(4):789-800.

Faris, M. A., R. C. Mafra, C. A. Ventura, and M. R. Araujo (1976). Estudos preliminares de consorcio de milho e sorgo, com duas leguminosas do Nordeste do Brasil. In SPA-Programs de sorgo e milheto. Boletim 3, Recife, Brazil. pp. 153-161.

Faris, M. A., R. C. Mafra, M. de A. Lira, et al. (1978). Estudos preliminares de consorciacao de milho e sorgo com duas leguminosas no Nordeste do Brasil. II. Contribuicao da consorciacao na produtividade da terra. Anais de XI Reuniao Brasileirs de Milho e Sorgo, Escola Superior de Agricultura "Luiz de Queiroz." Dept. Genetica, Piracicaba, pp. 753-766.

Faris, M. A., R. C. Mafra, M. de A. Lira, L. Ferraz, and G. R. de Lima (1977). A. Consorciacao de sorgo e milho con os feijoes de Arranca (Phaseolus vulgaris) e Macassar (Vigna unguiculata) (Walp). In Projeto Feijao Relatorio Anual de Pesquisas, Convenio SUDENE/IPA e Acordo UFRPE-IPA, Recife. pp. 88-97.

Fasoula, D. A. (1990). Correlations between auto-, allo- and nil-competiton and their implications in plant breeding. Euphytica 50:57-60.

Faulkner, O. J. and J. R. Mackie (1933). West African Agriculture. Cambridge Univ. Press, London. 
Fawusi, M. O. A. (1985). Influence of spatial arrangements on the growth, fruit and grain yields and yield components of intercropped maize and okra (Abelmoschus esculentus). Field Crops Res. 11:345352.

Federal Office of Statistics (1972). Nigeria rural economic survey consolidated report of crop estimation $1968 / 69$ to 1970/71. Agric. Statistics Unit, FOS, Lagos.

Federer, W. T. (1979). Statistical designs and response models for mixtures of cultivars. Agronomy J. 71:701-706.

Federer, W. T. (1979). Statistical design for mixtures of crops and other applications. Annais de Reuniao de Biometria, pp. 110-130.

Federer, W. T. (1982). Delineamento e Analise Estatistica de Experimentos de Consorciacao de Culturas. Dept. Metodos Quantitativos, EMBRAPA, Brasilia, D.F., Brasil, 195 pp.

Federer, W. T. (1987). Statistical analyses for intercropping experiments. Proc. 32nd Conf. Design of Experiments in Army Res. Dev. Testing, ARO Report 87-2, pp. 1-29.

Federer, W. T. (1989). Intercropping, developing countries, and tropical agriculture. Biometrics Bulletin 6:22-24.

Federer, W. T. (1991). Statistics and Society - Data Collection and Interpretation, 2nd edition. Marcel Dekker, Inc., New York, Basel, and Hong Kong, Chapters 5 and 6.

Federer, W. T. (1993). Statistical Design and Analysis for Intercropping Experiments. Volume I: Two Crops. Springer-Verlag, New York, Berlin, Heidelberg, London, Paris, Tokyo, Hong Kong, Barcelona, Budapest, $298+\mathrm{xx}$ pp.

Federer, W. T. (1993). Statistical design and analysis for intercropping experiments. In Crop Improvement for Sustainable Agriculture (ed: M. B. Callaway and C. A. Francis). Univ. NebraskaPress, Lincoln, Ch. 11, pp. 234-249.

Federer, W. T. (1994). Pooling and other procedures for analyzing laboratory samples more efficiently. The Statistician 43:413-422.

Federer, W. T. and B. R. Murty (1987). Uses, limitations and requirements of multivariate analyses for intercropping experiments. In Biomathematics (ed: I. B. MacNeill and G. J. Umphrey). D. Reidel Publ. Co., Dordrecht, pp. 269-283.

Federer, W. T. and D. Raghavarao (1987). Response models and minimal designs for mixtures of $\mathbf{n}$ of $\mathbf{m}$ items useful for intercropping and other investigations. Biometrika 74:571-577.

Federer, W. T. and L. N. Balaam (1972). Bibliography on Experiment and Treatment Design Pre-1968. Published for the International Statistical Inst. by Oliver \& Boyd, Ltd, Edinburg, 770 pp.

Federer, W.-T., A. Hedayat, C. C. Lowe, and D. Raghavarao (1976). Applications of statistical design theory to crop estimation, with special reference to legumes and mixtures of cultivars. Agronomy J. 69:914-919.

Federer, W. T., J. C. Connigale, J. N. Rutger, and A. Wijesinha (1982). Statistical analyses of yields from uniblends and biblends of eight dry bean cultivars. Crop Sci. 22:111-115.

Federer, W. T. and B. R. Murty (1987). Uses, limitations, and requirements of multivariate analyses for intercropping exsperiments. In Biostatistics (ed: I. B. MacNeill and G. J. Umphrey), D. Reidel Publ. Co., Dordrecht, pp. 269-283.

Federer, W. T. and S. J. Schwager (1982). On the distribution of land equivalent ratios. Tech. Rep. BU777-M, Biometrics Unit, Cornell Univ., Ithaca.

Federer, W. T. and A. Wijesinha (1979). Statistical definitions, designs, and response equations for experiments on fixed-ratio mixtures in agriculture. In Contributed Papers, 42nd Session, Intl. Statistical Inst., pp. 167-170.

Ferdinandez, D. E. F. (1979). Report of the intercropping division 1978. Miscellaneous crops and cattle husbandry in connection with coconut production. Ceylon Coconut Q. Lunuwila, Coconut Res. Inst. Ceylon 30(1/2):35-40.

Fernandez, Q. C. (1981). Desarrollo de sistemas de cultivo associado temporal cereal-soja. An Inst. Nac. Invest. Agrar. Ser. Agric. 15:23-32.

Fiebig, W. W., D. G. Schilling, and D. A. Knauft (1991). Peanut genotype response to interference from common cocklebur. Crop Sci. 31:1289-1292.

Fievet, G. (1979). Un pulverisateur adapte a l'exploitation de polyculture. Fermes Mod. No. 73. pp. 27-28. 
Filho, B. F. de S. (1986). Technical and economic aspects of the intercropping system of beans and sugar cane. Empresa Pesquisa Agrapecuaria Estado do Rio de Janeiro, 20 pp.

Finch, S. (1987). Horticultural crops. In Integrated Pest Management (ed: A.J. Burn, T.H. Coaker, and P.C. Jepson). Academic Press, London, pp. 257-293.

Fininsa, C. (1996). Effect of intercropping bean with maize on bean common bacterial blight and rust diseases. Intl. J.Pest Mgt. 42: 51-54.

Finlay, R. C. (1974). Intercropping with cereals. Reg. Soybean Conf., Addis-ababa, Univ. Dar es Salaam, Morogoro, Tansania. pp. 20.

Finlay, R. C. (1975). Intercropping soybeans with cereals. In Soybean Production, Protection and Utilization (ed: D. K. Wigham). INTSOY Series No. 6. Univ. Illinois at Urbana-Champaign. pp. 77-85.

Finlay, R. C. (1976). Cereal-legume breeding for intercropping. In Intercropping in Semi-Arid Areas (ed: J. H. Monyo, A. D. R. Ker, and M. Campbell). Univ. Dar es Salaam, Morogoro, Tanzania, and IDRC, Ottawa, Canada. p. 31.

Finlay, R. C. (1976). Crop production practices in intercropping systems. In Intercropping in Semi-Arid Areas (ed: J. H. Monyo, A. D. R. Ker, and M. Campbell). Univ. Dar es Salaam, Morogoro, Tanzania, and IDRC, Ottawa, Canada. p. 18.

Finlay, R. C., H. Y. Kayumbo, J. H. Monyo, and A. N. Mohuru (1974). The Morogoro intercropping research project. Proc. Fifth Eastern African Cereals Res. Conf. (ed: D. R. B. Manda). 311-315 pp.

Finney, D. J. (1990). Intercropping experiments, statistical analysis, and agricultural practice. Expl. Agric. 26:73-81.

Firbank, L. G. and A. R. Watkinson (1985). On the analsis of competition within two-species mixtures of plants. J. Applied Ecol. 22:503-507.

Fischer, R. A. (1979). Are your results confounded by intergenotypic competition? Proc. 5th Intl. Wheat Genetics Symp., pp. 767-777.

Fischer, R. A. and R. E. Miles (1973). The role of spatial pattern in the competition between crop plants and weeds. A theoretical analysis. Math. Biosci. 18:335-350.

Fisher, H. M. (1977). Studies in mixed cropping. I. Seasonal differences in relative productivity of crop mixtures and pure stands in the Kenya highlands. Expl. Agric. 13:177-184.

Fisher, H. M. (1977). Studies in mixed cropping. II. Population pressures in maize-bean mixtures. Expl. Agric. 13:185-191.

Fisher, L. J.; S. Bittman, Z. Mir, et al. (1993). Nutritional evaluation of ensilage made from intercropped corn and sunflowers. Can. J. Animal Sci. 73:539-545.

Fisher, N. M. (1975). Investigations into the competitive relations of maize and beans in mixed crops. Tech. Comm. 14, Dept. Crop Sci., Univ. Nairobi, Kenya.

Fisher, N. M. (1975). Seasonal differences in the relative productivity of crop mixtures and pure stands at Robete. Tech. Comm. No. 14, Univ. Nairobi, Kenya.

Fisher, N. M. (1976). A limited objective approach to the design of agronomic experiments with mixed crops. In Intercropping in Semi-Arid Areas (ed: J. H. Monyo, A. D. R. Ker, and M. Campbell). Univ. Dar es Salaam, Morogoro, Tanzania, and IDRC, Ottawa, Canada. p. 47.

Fisher, N. M. (1977). Studies in mixed cropping. I. Seasonal differences in relative productivity of crop mixtures and pure stands in the Kenya highlands. Expl. Agric. 13:177-184.

Fisher, N. M. (1977). Studies in mixed cropping. II. Population pressures in maze-bean mixtures. Expl. Agric. 13:185-191.

Fisher, N. M. (1979). Studies in mixed cropping. III. Further results with maze-bean mixtures. Expl. Agric. 15:49-58.

Flannery, H. L. (1981). Hairy vetch vs. rye cover crops for corn sileage productiion using no-till. Better Crops Plant Food 65(3):3-6.

Flannery, R. L. (1981). Hairy vetch vs. rye cover crops for corn silage production using no-till. Better Crops Plant Food 66:22-25.

Fleming, A. A., J. E. Giddens, and E. R. Beaty (1981). Corn yields as related to legumes and inorganic nitrogen. Crop Sci. 21:977-980. 
Flinn, J. C. (1978). Agro-economic considerations in cassava intercropping research. Los Banos, Philippines: International Rice Research Institute. $37 \mathrm{pp}$.

Flinn, J. C. (1979). Agro-economic considerations in cassava intercropping research. Ottawa, Intl. Dev. Res. Centre. pp. 37-41, 87-101.

Flint, E. P., D. T. Patterson, and J. L. Beyers (1983). Interference and temperature effects on growth of cotton Gossypium hirsutum cultivar Stoneville-213, Spurred Anoda Anoda cristata and Velvetleaf Abutilon theophrasti. Weed Sci. 31(6):892-898.

Flint, M. L. and P. A. Roberts (1988). Using crop diversity to manage pest problems: some California examples. Amer. J. Alternative Agric. 3:163-167.

Flora, C. B. (1988). Farming systems approaches to international technical cooperation in agriculture and rural life. Humanities Agric. 5:24-34.

Florez, O. G., A. R. Munoz. and F. J. Aries (1984). Evaulation of several cassava (Manihot esculenta Crantz) maize (Zea mays L.) and beans (Phaseolus vulgaris L.) intercropping middle temperature climate. Rev. Inst. Colomb. Agropecu. 19:301-306.

Flowers, N. M. and D. W. Werner (1982). Variation in swidden practices in four central Brazilian Indian societies ethnic groups. Hum. Ecol. 10(2): 203-217.

Floyd, B. (1969). Eastern Nigeria. A Geographical Review. MacMillan, London.

Follett, R. F. (1989). Nitrogen Management and Groundwater Protection. Elsevier Science Publ, Co., New York.

Fonseca, D. (1981). Effect of population and spatial arrangements of cowpea (Vigna unguiculata) and peanut (Arachis hypogaea) grown in association with cassava (Manihot esculenta Crantz) on production and intensity of land use (in Spanish). Teses de Grado, Facultad de Ciencias Agropecuaries, Universad Nacional, Palmira, Columbia.

Fonseca, P. D. and D. E. Leihner (1983). Effects of plant densities and spatial arrangements of cowpeas (Vigna unguiculata) and peanuts (Arachis hypogea) in association with cassava (Manihot esculenta) on the production and intensity of use of the soil (Intercropping, yields, Colombia). Acta. Agron. 33(2):17-27.

Fontes, L. A. N., J. D. Glavao, and W. S. Couto (1976). Estudo de sistemas culturais milho-feijao no municipio de Vicosa, Minas Gerais. Rev. Ceres 23(130):484-496.

Fordham, R. (1983). Intercropping what are the advantages? Outlook Agric. 12:142-146.

Forney, D. R., C. L. Foy, and D. D. Wolf (1985). Weed suppression in no-till alfalfa (Medicago sativa) by prior cropping of summer annual forage grasses. Weed, Sci. 33:490-497.

Fortin, M.-C. and M. Edwards (1995). Leaf area of strip-intercropped corn in dry and normal growing seasons. Agronomy J. 87:569-574.

Fortin, M.-C., J. Culley, and M. Edwards (1994). Soil water, plant growth and yield of strip-intercropped corn. J. Prod. Agric. 7:63-69.

Forwood, J. R., P. Stypinski, and J. A. Paterson (1989). Forage selection by cattle grazing orchardgrasslegume pastures. Agronomy J. 81:409-414.

Foster, R. K. (1990). Effect of tillage implement and date of sweet-clover incorporation on available soil N and succeeding spring wheat yields. Can. J. Plant Sci. 70:269-277.

Fox, F. M. and M. M. Caldwell (1978). Competitive interaction in plant populations exposed to supplementary UV-B radiation. Oecologia 36(2):173-190.

Fox, R. H. and W. P. Piekielek (1988). Fertilizer N equivalence of alfalfa, birdsfoot trefoil, and red clover for succeeding corn crops. J. Prod. Agric. 1:313-317.

Frame, J. and R. D. Harkess (1987). The productivity of four forage legumes sown alone and with each of five companion grasses. Grass Forage Sci. 42:213-223.

Francis, C. (1993). Contour strip intercropping and rotations to reduce soil erosion and energy costs in production systems. Sustainable Agric. Res. Educ. (SARE) or Agric. in Concert with the Environ. (ACE) res. proj., $11 \mathrm{pp}$.

Francis, C. A. (1978). Multiple cropping potentials of beans and maize. Hort. Sci. 13:12-17.

Francis, C. A. (1980), Development of plant genotypes for multiple cropping systems. In Plant Breeding Symp. II (ed: K. J. Frey), Iowa State Univ. Press, Ames, ch. 7.

Francis, C. A. (1985). Intercropping competition and yield advantage. In World Soybean Research Conference III: Proc. (ed: R. Shibles). pp. 1017-1024. 
Francis, C. A. (1985). Variety development for multiple cropping systems. Crit. Rev. Plant Sci. 3:133168.

Francis, C. A. (1986). Future perspectives of multiple cropping. In Multiple Cropping Systems (ed: C. A. Francis), Macmillan, New York, pp. 351-.

Francis, C. A. (1986). Multiple Cropping Systems. Macmillan, New York.

Francis, C. A. (1988). Internal resources for sustainable agriculture. Intl. Inst. Environ. Dev., Sustainable Agric. Prog., 15 pp.

Francis, C. A. (1990). Biological efficiencies in multiple cropping systems. Adv. Agron. 42:1-42.

Francis, C. A. and M. B. Callaway (1993). Crop improvement for future farming systems. In Crop Improvement for Sustainable Agriculture (ed; M. B. Callaway and C. A. Francis), Univ. Nebraska Press, Lincoln and London, pp. 1-18.

Francis, C. A. and J. H. Sanders (1978). Economic analysis of bean and maize systems: monoculture versus associated cropping. Field Crops Res. 1(4):319-335.

Francis, C. A. et al. (1990). Sustainable Agriculture in Temperate Zones. John Wiley \& Sons, Inc., New York.

Francis, C. A., A. Jones, R. K. Crookston, et al. (1986). Strip cropping corn and grain legumes. A review. Amer. J. Altern. Agric. 1:159-164.

Francis, C. A., C. A. Flor, and M. Prager (1976). Contrastes agroeconomicos entre el monocultivo de maiz y la associacion maiz-frijol. Cali, Colombia: CIAT. $26 \mathrm{pp.}$

Francis, C. A., C. A. Flor, and S. R. Temple (1976). Adapting varieties for intercropping systems in the tropics. Multiple Cropping (ed: R. I. Papendick et al.). ASA Spec. Publ. No. 27, ASA, Madison, WI, pp. 235-253.

Francis, C. A., C. A. Flor, M. Prager, and J. H. Sanders (1978). Density response of climbing beans in two cropping systems. Field Crops Res. 1:255-267.

Francis, C. A., M. Prager, and D. R. Liang (1978). Genotype $\times$ environment interactions in climbing bean cultivars in momoculture and associated with maize. Crop Sci. 18:242-247.

Francis, C. A., M. Prager, and G. Tejada (1982). Density interactions in tropical intercropping. II. Maize (Zea mays L.) and bush beans (Phaseolus vulgaris). Field Crops Res. 5:253-264.

Francis, C. A., M. Prager, and G. Tejada (1982). Density interactions in tropical intercropping. I. Maize (Zea mays L.) and climbing bean (Phaseolus vulgaris L.). Field Crops Res. 5:163-176.

Francis, C. A., M. Prager, and G. Tejada (1982). Effects of relative planting dates in bean Phaseolus vulgaris and maize Zea mays intercropping patterns. Field Crops Res. 5(1):45-54.

Francis, C. A., M. Prager, C. A. Flor, and R. Hudgens (1977). Experimental associated cropping of beans and maize in Colombia. Annu. Rep. Bean Improv. Coop. 20:17-18.

Francis, C. A., M. Prager, C. A. Flor, and R. Hudgens (1978). Effects of bean association on yields and yield components of maize. Crop Sci. 18:760-764.

Francis, C. A., M. Prager, D. R. Liang, and C. A. Flor (1978). Genotype $\times$ environment interactions in bush bean cultivars in monoculture and associated with maize. Crop Sci. 18:237-242.

Francis, C. A., M. Prager, G. Tejada, and D. R. Liang (1983). Maize genotype by cropping pattern interactions: Monoculture vs. intercropping. Crop Sci. 23:302-306.

Francis, C. A., S. R. Temple, C. A. Flor, and C. O. Grogan (1978). Effects of competition on yield and dry matter distribution in maize. Field Crops Res. 1:51-63.

Francis, R. and D. R. Decoteau (1993). Developing an effective southernpea and sweet corn intercrop system. Hort. Tech. 3:178-184.

Frankow-Lindberg, B. E. (1986). Competition in field-sown swards of lucerne or red clover and timothy. Swed. J. Agric. Res. 16:119-128.

Fred, E. B., I. L. Baldwin, and E. M. Coy (1932). Root nodule bacteria and leguminous plants. Univ. Wisconsin Studies in Sci. 5, $343 \mathrm{pp}$.

Fredshavn, J. R., G. S. Poulsen, I. Huybrechts, and P. Rudelsheim (1995). Competitiveness of transgenic oilseed rape. Transgenic Res. pp. 142-148.

Freyman, S. and G. B. Schaalje (1983). Harmful effects of worked-down winter wheat on spring seeded wheat and rapeseed. Can. J. Plant Sci. 63:299-301.. 
Freyman, S. and J. Venkateswarlu (1977). Intercropping on the rainfed red soils of the Deccan Plateau, India. Can. J. Plant Sci. 57:697-705.

Fribourg, H, A. and W. V. Bartholomew (1956). Availability of nitrogen from crop residues during first and second seasons after application. Soil Sci. Soc. Amer. Proc. 20:505-508.

Fribourg, H. A. and J. R. Overton (1979). Persistence and productivity of tall fesue in bermudagrass sods subjected to different management systems. Agronomy J. 71:620-624.

Fribourg, H. A., A. B. Chestnut, R. W. Thompson, et al. (1991). Steer performance in fescue-clover pastures with different levels of endophyte infestation. Agronomy J. 83:777-781.

Fribourg, H. A., J. B. McLaren, K. M. Barth, et al. (1979). Productivity and quality of bermudagrass and orchardgrass-ladino clover pastures for beef steers. Agronomy J. 71:315-320.

Fribourg, H. A., L. S. Jeffery, J. R. Evans, et al. (1978). Clover establishment in fescue sods following renovation with disking and herbicides. Tennessee Farm Home Sci Prog. Rep 105, Univ. Tennessee, Knoxville.

Fribourg, H. A., R. J. Carlisle, and J. B. McLaren (1984). Bermudagrass, tall fescue, and orchardgrass pasture combinations with clover or $\mathrm{N}$ fertilization for grazing steersl II. The species combination index and variability in forage growth and consumption, and animal performance. Agronomy J. 76:615-619.

Friedrichs, K. (1928). Waldkastastrophen in biozinotischer Betrachtung. Anzeiger Fuer Schaedlingskunde 4:139-142.

Frye, W. W. and R. L. Blevins (1989). Economically sustainable crop production with legume cover crops and conservation tillage. Soil Water Conserv. 44:57-60.

Frye, W. W., J-J. Varco, R. L. Blevins, et al. (1988). Role of annual legume cover crops in efficient use of water and nitrogen. In Cropping Strategies for Efficient Use of Water and Nitrogen (ed: W. L. Hargrove and B. G. Ellis). ASA Spec. Publ. 51, Madison, WI, pp.129-154.

Frye, W. W., W. G. Smith, and R. J. Williams (1985). Economics of winter cover crops as a source of nitrogen for no-till corn. J. Soil Water Conserv. 40:246-249.

Fuentes, O. A. (1954). Efecto de 15 leguminosas en un experimiento de siembras intercaladas con maiz. In Proyecto Cooperative Centroamericano, Mejoramieonto del Maiz. I Reunion Centroamericano, Turrialba, Costa Rica. pp. 398-403.

Fuerst, E. P. and A. R. Putnam (1983). Separating the competitive and allelopathic components of interference: Theoretical principles. J. Chem. Ecol. 9:937-944.

Fujita, K., K. G. Ofosu-Budu, and S. Ogata (1992). Biological nitrogen fixation in mixed legume-cereal cropping systems. Dev. Plant Soil Sci. 49:155-175.

Fukai, S. and B. R. Trenbath (1993). Processes determining intercrop productivity and yields of component crops. Field Crops Res. 34:247-271.

Fuller, P. A., D. P. Coyne, J. R. Steadman, and R. F. Mumm (1984). Inter- and intra-row inter-genotypic competition influences selection for avoidance of white mold disease in dry edible beans. J. Amer. Hort. Sci. 48:659-665.

Fuller, W. A. and F. B. Cady (1965). Estimation of asymptotic rotation and nitrogen effects. Agronomy J. 57:299-302.

Furoc, R. C., D. Z. Magpantay, and E. Q. Javier (1977). Intercropping of fodder soybean ( Glycine max (L.)Merr.) with green corn. $8^{\text {th }}$ Annual Meeting Crop Sci. Soc. Philippines, La Trinidad, Benquet, Philippines. 8 pp.

Fussell, L. K. and P. G. Serafini (1985). Crop association in the semi-arid tropics of West Africa. Research strategies, past and future. In Appropriate Technology for Farmers in the Semi-Arid West Africa (ed: W. Ohm and J. C. Nagy). Purdue Univ.

Fye, R. E. (1972). The interchange of insect parasites and predators between crops. Pest Articles and News Summaries 18:143-146.

Fyfe, J. L. and H. H. Rogers (1965). Effects of varying variety and spacing on yields and composition of mixtures of lucerne and tall fescue. J. Agric. Sci. (Camb.) 64:351-359.

Gage, S. (1993). Development of methods toward sustainable apple and poultry production. Sustainable Agric. Res. Educ. (SARE) or Agric. in Concert with the Environ. (ACE) res. proj., 44 pp.

Gahlot, K. N. S., R. Vishal, and S. J. Vishwakarma (1978). Urd 'T.9' as intercrop with arhar 'T.21'. Indian Farming 27(10):7-8. 
Gajaseni, J. and C. F. Jordan (1992). Theoretical basis for Taungya and its improvement. Sustainable Rural Dev. Ser. 1:68-81.

Gakale, L. P. and M. D. Clegg (1987). Nitrogen from soybean for dryland sorghum. Agronomy J. 79:1057-1061.

Galal, Jr., S. (1981). Intercropping corn with soybean in Egypt, in the battle against food crisis. Addis Ababa, Ethiopia. pp. 29-42.

Galal, Jr., S., L. H. Hindi, A. F. Ibrahim, and H. H. Elhinnawy (1974). Intercropping tolerance of soybean in different local corn stocks. (Zea mays L.). Z. Acker Pflanzenbau. 139(2):135-145.

Galal, Jr., S., L. H. Hindi, A. F. Ibrahim, and H. H. Elhinnawy (1974). Intercropping corn with soybean as a bio-assaying method for screening shade-tolerant corn stocks ( Zea mays L.). Z. Pflanzenzucht. 71(2):185-186.

Galal, Jr.. S. and A. A. Metwally (1982). The variability in intercropping-tolerance of 18 soybean varieties when grown with a newly developed corn stock "Cairo 1". Ain Shams Univ. Fac. Agric. Issue $2102,15 \mathrm{pp}$.

Gallaher, R. N. (1977). Soil moisture conservation and yield of crops no-till planted in rye. Soil Sci. Soc. Amer. J. 41:145-147.

Gallasch, H. (1976). Integration of cash and food cropping in the lowlands of Papula New Guinea. In Proc. Papula New Guinea Food Crops Conf. (ed: K. Wilson and R. M. Bourke). Dept. Primary Industry, Port Moresby, Papula New Guinea. pp. 101-115.

Gallasch, H. (1977). Grow food crops under your coconuts. Lowlands Agric. Expl. Sta., Keravat, Papula New Guinea, Information Bull. 12. pp. 1-5.

Galwey, M. A., M. A. De Querioz, and R. Willey (1986). Genotypic-variation in the response of sorghum to intercropping with cowpea, and in the effect on the associated legume. Field Crops Res. 14:263-290.

Ganapathy, S., V. Balakrishnan, and P. Selvaraj (1972). Mixed cropping in rainfed ragimillet. - A case study in Talavadi Block of Coimbatore District. India. Farm Fact. 6(11):17-19.

Gangasaran, G. and G. Giri (1985). Intercropping of mustard with chickpea, lentil and barley in drylands. Indian J. Agric. 30:244-250.

Gangwar, B. (1977). All about inter- and mixed cropping. Farmer Parliament 12(4):7-8.

Gangwar, B. (1977). Mixed cropping of maize - a review. Farmer Parliment 12(12):13-14, 24.

Gangwar, B. and G. S. Kalra (1979). Studies on mixed cropping of legumes with maize under rainfed conditions. Madras Agric. J. Coimbatore 66(7):425-429.

Gangwar, B. and G. S. Kalra (1982). Intercropping of rainfed maize with different legumes. Indian J. Agric. Sci. 52(2):113-116.

Gantzer, C. J., S. H. Anderson, A. L. Thompson, and J. R. Brown (1991). Evaluation of soil loss after 100 years of soil and crop management. Agronomy J. 83:74-77.

Gardiner, T. R. and L. E. Craker (1981). Bean growth and light interception in a bean-maize intercrop. Field Crops Res. 4:313-320.

Gardner, F. P. and J. Kisakye (1990). Productivity of bean/maize intercrops as influenced by bean type and planting date and maize density. Proc. Soil Crop Sci. Soc. Fla. 49:139-146.

Garrett, H. E., J. E. Jones, W. B. Kurtz, and.J. P. Slusher (1991). Black walnut (Juglans nigra L.) agroforestry is design and potential as a land-use alternative. For. Chron. 67:213-218.

Garver, C. (1979). Proceedings of the International Workshop on Intercropping. ICRISAT, Hyderabad, India..

Gates, D. J. (1980). Competition between 2 types of plants located at random on a lattice. Math Biosci. 20(3):183-192.

Gautam, O. P., V. H. Shah, and K. P. M. Nair (1964). Agronomic investigations with hybrid maize. II. Study of intercropping, row spacing and method of phosphorus application with hybrid maize. Indian J. Agron. 9:247-254.

Gautam, R. C. and S. K. Kaushik (1980). Studies on planting dates and productivity of intercropping system of pearlmillet with short duration grain legumes. Indian J. Agron. 25(3):441-446.

Gedge, D. L., W. R. Fehr, and A. K. Walker (1977). Intergenotypic competition between rows and within blends of soybeans. Crop Sci. 17:787-790. 
Genest, J. and H. Steppler (1973). Effects of companion crops and their management on the undersown forage seedling environment. Can. J. Plant Sci. 53:285-290.

George, T., J. K. Ladha, D. P. Garrity, and R. J. Buresh (1994). Legumes as nitrogen catch crops during the dry-to-wet transition in lowland rice cropping systems. Agronomy J. 86:267-273.

George, T., J. K. Ladha, R. J. Buresh, and D. P. Garrity (1992). Managing native and legume-fixed nitrogen in lowland rice-based cropping systems. Plant Soil 141:69-91.

George, T., J. K. Ladha, R. J. Buresh, and D. P. Garrity (1993). Nitrate dynamics during the aerobic soil phase in lowland rice-based cropping systems. Soil Sci. Soc. Amer. J. 57:1526-1532.

Gerber, J. M., J. E. Brown, and W. E. Splittstoesser (1983). Intercropping vegetables with plastic mulch and row tunnels. Proc. Natl. Plast. Congr., pp. 24-27.

Gersper, P. L., C. S. Rodriguez-Barbosa, and L. F. Orlando (1993). Soil conservation in Cuba: a key to the new model for agriculture. Agric. Human Values 10(3):16-23.

Gethi, M. and B. M. Khaemba (1991). Damage by pod-sucking bugs on cowpea when intercropped with maize. Trop. Pest Mgt. 37:236-239.

Gettle, R. M., J. R. George, K. M. Blanchet, D. R. Buxton, K. J. Moore (1996). Frost-seeding legumes into established switchgrass: Forage yield and botanical composition of the stratified canopy. Agronomy J. 88:555-560.

Geyer, W., W. Lamont, and C. Long (1996). Intercropping walnut and pine with crops. Proc. Amer. Foresters Natl. Convention, pp. 417-418.

Ghafar, Z. and A. K. Watson (1983). Effect of corn (Zea mays L.) seeding rate on growth of yellow nutsedge (Cyperus Esculentus). Weed Sci. 31:572-575.

Ghaffarzadeh, M., F. Garcia-Prechac, R. M. Cruse 1994). Grain yield response of corn, soybean, and oat grown in a strip intercropping system. Amer. J. Alternative Agric. 9:171-177.

Ghewande, M. P., A. K. Shukla, and R. N. Pandey (1986). Management of foliar diseases of groundnut through agronomic practices. Indian Bot Rep. 5:179-181.

Ghewande, M. P., S. Desai, P. Narayan, and A. P. Ingle (1993). Integrated management of foliar diseases of groundnut (Arachis hypogaea L.) in India. Intl. J. Pest Mgt. 39:375-378.

Ghodake, R. D. (1995). Intercropping of coffee in the highlands of Papua New Guinea. Agric. Res. Div., Konedohu, Papua New Guines, 46 pp.

Ghosh, S. P. and S. Chand (1984). Nutrient status of peach leaf affected by intercrops. Indian J. Agric. Sci. 54:450-451.

Ghosh, S. P., G. M. Nair, N. G. Pillai, et al. (1987). Growth, productivity and nutrient uptake by cassava in association with four perennial species. Trop. Agric. 64:233-236.

Ghuman, B. S. and R. Lal (1991). Comparative evaluation of some inter-cropping systems in the humid tropics of southern Nigeria. J. Sustainable Agric. 2:59-73.

Giacomelli, G., I. Grasgreen, and H. Janes (1987). Lettuce and tomato intercropping system with supplemental lighting. Soil Cult. 3:39-50.

Gibberd, V. (1995). A farmer-friendly research project in semi-arid Kenya. Trop. Sci. 35:308-320.

Gibberd, V. (1995). Yield responses of food crops to animal manure in semi-arid Kenya. Trop. Sci. 35:418-426.

Gibberd, V. (1996). Concentrating rainfall to enhance soil moisture in Kenya's semi-arid areas. Trop. Sci. 36:143-153.

Gibbon, D. (1974). Dryland crop production systems in semi-arid Botswana: Their limitations and potential for improvement. Proc. Intl. Workshop on Farming Systems. ICRISAT, Hyderabad, India. pp. 351-360.

Gichuru, M. P. (1991). Residual effects of natural bush, Cajanus cajan and Tephrosia candida on the productivity of an acid soil in southeastern Nigeria. Dev. Plant Soil Sci. 45: 417-422.

Giddens, J., S. Arsjad, and T. H. Rogers. (1965). Effect of nitrogen and green manures on corn yield and properties of a Cecil soil. Agronomy J. 57:466-469.

Gill, A. S. and B. D. Patil (1985). Subabul for forage production under intercropping: a new approach. Indian Farming 35:37, 39-40.

Gill, A. S., and Patil, B. D. (1983). Intercropping pays in rabi fodder crops yields. Indian Farming 32(12):32. 
Gill, A. S., B. D. Patil, and C. L. Yadav (1982). Intercropping studies in Leucaena. Leucaena Res. Rep. Taipei, Taiwan 3:30.

Gill, D. W. and E. J. Kamprath (1990). Potassium uptake and recovery by an upland rice-soybean rotation in an oxisol. Agronomy J. 82:329-333.

Gillard, P. and W. H. Elberse (1982). The effect of nitrogen and phosphorus supply on the competition between Cenchrus biflorus and A]sicarpus ovalifolius. Neth. J. Agric. Sci. 30(3):161-172.

Gillespie, T. J. and G. E. Kidd (1980). Field tests of an electronic apple scab alarm. Can. J. Plant Sci. 60(1):213-220.

Gilliver, B. and S. C. Pearce (1983). A graphical assessment of data from intercropping factorial experiments. Expl. Agric. 19:23-31.

Giri, A. N. and U. C. Upadhyay (1980). Correlation and regression studies in 'H 4' upland cotton under different planting patterns and intercropping systems. Indian J. Agric. Sci. 50(11):907-910.

Giri, A. N. and U. C. Upadhyay (1980). Pattern of dry-matter accumulation, N nitrogen concentration and uptake in hybrid cotton under different planting pattern and intercropping system. Indian J. Agron. 25(4):614-623.

Giri, A. N. and U. C. Upadhyay (1980). Studies on planting pattern, intercropping and nitrogen economy of H-4 cotton under rainfed conditions. Indian J. Agron. 25(1):71-76.

Giri, G. and R. De (1978). Intercropping of pigeonpea with other grain legumes under semi-arid rainfed conditions. Indian J. Agric. Sci. 48:659-665.

Gizlice, Z., T. E. Carter, Jr., and J. W. Burton (1988). Identification of a desirable blend combination in southern soybeans. Soybean Genet. Newsl. 15:173-176.

Gizlice, Z., T. E. Carter, Jr., and J. W. Burton (1989). The impact of maturity and genotype on blend performance in group V and group VII soybean cultivars. Agronomy J. 81:559-562.

Glazer, G. (1975). Food production and the 'Green Revoluation' in developing counties. Appl. Sci. Dev. 5:124-133.

Gleave, M. B. and White, H. P. (1972). Agricultural Systems and Pastorialism in Tropical Africa. Hicks Smith \& Sons, Wellington.

Gleeson, A. C. and C. A. McGilchrist (1978). Analysis of plant competition data from an incomplete mixture diallel experiment. J. Agric. Sci. 91(2):419-426.

Gliemeroth, G. (1950). Untersuchungen uber die Einspritzung von Speiserbsen. Zeitschrift fur Acker-undPflanzenbau 91:519-544.

Gliessman, S. R. (1985). Economic and ecological factors in designing and managing sustainable agroecosystems. In Sustainable Agriculture \& Integrated Farming Systems Proc. (ed: T. C. Edens, C. Fridgen, and S L. Battenfield), pp. 56-63.

Gliessman, S. R. and M. A. Altieri (1982). Polyculture cropping has advantages. Weed and insect control. California Agric. Expt. Sta., Berkeley, Calif. Agric. 36(7):14-16.

Godfrey, L. D. and T. F. Leigh (1994). Alfalfa harvest strategy effect on lygus bug (Hemiptera: Miridae) and insect predator population density: implications for use as trap crop in cotton. Environ. Entomology 23:1106-1118.

Godoy, R. and C. P. A. Bennett (1991). The economics of monocropping and intercropping by smallholders: the case of coconuts in Indonesia. Hum Ecol. 19:83-98.

Gold, C. S. and J. A. Wightman (1991). Effects of intercropping groundnut with sunhemp on termite incidence and damage in India. Insect Sci. Appl. 12:177-182.

Gold, C. S., M. A. Altieri, and A. C. Bellotti (1989). Cassava intercropping and pest incidence: a review illustrated with a case study from Colombia. Trop. Pest Mgt. 35:339-344.

Gold, C. S., M. A. Altieri, and A. C. Bellotti (1989). The effects of intercropping and mixed varieties of predators and parasitoids of cassava whiteflies (Hemiptera: Aleyrodidae) in Colombia. Bull. Entomol. Res. 79:115-121.

Gold, C. S., M. A. Altieri, and A. C. Bellotti (1990). Effects of intercropping and varietal mixtures on the cassava hornworm, Erinnyis ello L. (Lepidoptera: Sphingidae), and the stemborer, Chilomima clarkei (Amsel) (Lepidoptera: Pyralidae), in Colombia. Trop.Pest Mgt. 36:362-367.

Gold, C. S., M. A. Altieri, and A. C. Bellotti (1991). Survivorship of the cassava whiteflies Aleurotrachelus socialis and Trialeurodes variabilis (Homoptera: Aleyrodidae) under different cropping systems in Colombia. Crop Prot. 10:305-309. 
Goldberg, D. E. and P. A. Werner (1983). Equivalence of competitors in plant communities: A null hypothesis and a field experimental approach. Amer. J. Botany 70:1098-1104.

Goldstein, W. (1992). Improving the ecology of corn production and testing perennial alternatives to silage corn. Sustainable Agric. Res. Educ. (SARE) or Agric. in Concert with the Environ. (ACE) res. proj., $24 \mathrm{pp}$.

Gomes, D. T. Establishment methods and comparative performance of five tropical legumes in grass sods. Ph.D. Thesis, Univ. Florida, Gainesville..

Gomez, A. A. and K. A. Gomez (1983). Multiple Cropping In the Humid Tropics of Asia. Intl. Dev. Res. Centre, Ottawa, $248 \mathrm{p}$.

Gomm, F. B., F. A. Sneva, and R. J. Lorenz (1976). Multiple cropping in the Western United States. In Multiple Cropping (ed: R. I. Papendick et al.), ASA Spec. Publ. 27, ASA, Madison, WI, pp. 103116.

Gooding, H. G. (1963). The agronomlc aspects of pigeon peas. Indian J. Agron. 7:331-340.

Goodman, P. J. (1988). Nitrogen fixation, transfer, and turnover in upland and lowland grass-clover swards, using ${ }^{15} \mathrm{~N}$ isotope dilution. Plant Soil 112:247-254.

Gopalakrishnan, R. (1975). Pulses production and research and the scope for multiple and intercropping of pulses in Kerala. Indian J. Genet. Plant Breed. 35(2):300-302.

Gopikrishna, P. and V. S. Shanmuga-Sundaram (1988). Effect of population levels of soybean on physiological growth parameters of sorghum $\mathrm{CO} 24$ in sole and intercropped stand. Z. Acker Pflanzenbau 161:45-49.

Gordon, A. M. and P. A. Williams (1988). Intercropping valuable hardwood tree species and agricultural crops. Agrologist 17:12-14.

Gordon, A. M. and P. A. Williams (1991). Intercropping valuable hardwood tree species and agricultural crops in southern Ontario. For. Chron. 67:200-208.

Gore, A. J. P., R. Cox, and T. M. Davies (1979). Wear tolerance of turfgrass mixtures. J. Sports Turf Res. Inst. 55:45-68.

Gotoh, K. and T. T. Chang (1979). Adaptation to production systems. In Plant Breeding Perspectives (ed: J. Sneep and A. J. T. Hendriksen). PUDOC Centre Agric. Publ. Doc., Wageningen, pp. 253-261.

Gouveia, G. A., N. Ahmad, and S. M. Griffith (1995). Urea-N uptake by dasheen (Colocasia esculenta L. Schott) in relation to the fertilizer placement method. Fertilizer Res.. 42:205-214.

Govindarajan, M., M. R. Rao, M. N. Mathuva, and P. K. Ramachandran Nair (1996). Soil-water and root dynamics under hedgerow intercropping in semiarid Kenya. Agronomy J. 88:513-520.

Goyal, R. S. (1984). A cropping system for saline water irrigation. Indian Farming 34:16-18.

Grabau, L. J. and T. W. Pfeiffer (1990). Management effects on harvest losses and yield of double-crop soybean. Agronomy J. 82:715-718.

Grace, J. B. , J. Keough, and G. R. Guntenspergen (1992). Size bias in traditional analyses of substitutive competition experiments. Oecologia 90:429-434.

Grafius, J. E. (1966). Rate of change of lodging resistance, yield, and test weight in varietal mixtures of oats, Avena sativa L. Crop Sci. 6:369-370.

Graham, P. L., J. L. Steiner, and A. F. Wiese (1988). Light absorption and competition in mixed sorghum-pigweed communities. Agronomy J. 80:415-418.

Grasgreen, I., H. Janes, and G. Giacomelli (1986). The growth of hydroponic lettuce under tomatoes with supplemental lighting. Proc. Natl. Plast Congr., Issue 19, pp. 193-202.

Graves, C. R., T. McCutchen, L. S. Jeffery, et al. (1980). Soybean-wheat cropping systems. Evaluation of planting methods, varieties, row spacings, and weed control. Tennessee Agric. Expt. Sta. Bull. 597.

Graves. C. R. and T. McCutchen (1978). Wheat following corn or soybeans Tenn. Farm Home Sci. 106:19-20.

Gray, S. (1994). Raised bed gardening. Coop. Ext. Serv., Oklahoma State Univ., OSU Ext. Facts, 4 pp.

Grecu, S. J., M. B. Kirkham, E. T. Kanemasu, et al. (1988). Root growth in a claypan with a perennialannual rotation. Soil Sci Soc, Amer. J. 52:488-494.

Griffin, J. L. and R. W. Taylor (1986). Alternative establishment methods for wheat following soybean. Agronomy J. 78:487-490. 
Griffin, J. L., R. W. Taylor, and R. J. Habetz (1984). Conservation tillage for double-cropped soybeans in southwestern Louisiana. J. Soil Water Conserv. 39:78-80.

Griffin, T. S. and O. B. Hesterman (1989). Effect of forage legume species and harvest management on nitrogen contributions in legume-potato rotations. Proc. Amer. Forage Grassl. Council, Belleville, PA., pp. 68-72.

Griffin, T. S. and O. B. Hesterman (1991). Potato response to legume and fertilizer nitrogen sources. Agronomy J. 83:1004-1012.

Griffith, D. R., E. J. Kladivko, J. V. Mannering, et al. (1988). Long-term tillage and rotation effects on corn growth and yield on high and low organic matter, poorly drained soils. Agronomy J. 80:599605.

Grigg, D. B. (1974). The Agricultural Systems of the World: An Evolutionary Approach. Cambridge Univ. Press, London.

Griggs, T. C. and A. G. Matches (1991). Productivity and consumption of wheatgrasses and wheatgrasssainfoin mixtures grazed by sheep. Crop Sci. 31:1267-1273.

Grimes, R. C. (1962). Intercropping and alternate row cropping of cotton and maize. E. Afr. Agric. For. J. 28:161-163.

Grisley, W. (1994). Farmer-to-farmer transfer of new crop varieties: an empirical analysis on small farms in Uganda. Agric. Economics 11:43-49.

Grissco, R., C. Johnson, and W. Dumas (1984). Experiences in planting cotton in various cover crops. Proc. 7th Annual Southeast No-Tillage System Conf., Alabama Agric. Expt. Sta., pp. 58-61.

Groffman, P. M., P. E. Hendrix, and D. A. Crossley, Jr. (1987). Nitrogen dynamics in conventional and no-tillage agroecosystems with inorganic fertilizer or legume nitrogen inputs. Plant Soil 97:315332.

Grossman, J. (1993). Botanical pesticides in Africa. IPM Practitioner 15(1):1-9.

Grossman, J. (1993). Fighting insects with living mulches. IPM Practitioner 15(10):1-8.

Grossman, J. and W. Quarles (1993). Strip intercropping for biological control. IPM Practitioner 15(4):111.

Grove, A. T. (1970). Africa South of the Sahara. Oxford Univ. Press, London.

Groya, F. L. and C. C. Sheaffer (1981). Establishment of sod-seeded alfalfa at various levels of soil moisture and grass competition. Agronomy J. 73:560-565.

Grubinger, V. P. and P. L. Minotti (1990). Managing white clover living mulch for sweet corn production with partial rototilling. Amer. J. Alternative Agric. 5:4-5.

Guazzelli, R. J. and S. Miyasaka (1972). Sistema de cultivo e rotacao de culturas. In Anais do I Symposio Brasileiro de Feijao. Vicosa, U. F. V., pp. 255-261.

Guevera, J. C. (1962). Effecto de las practicas de siembra y de cultivos sobre plagas en maiz y frijol. Fitotecnia Latinoamericana (Costa Rica) 1(1):15-26.

Guinard, A. (1961). Le Systeme Cultural de la region de Man (Cote d'Ivoire). Agronomie Tropicale XVI (2):148-178.

Guldan. S. J., C. A. Martin, J. C. Wong, and R. L. Steiner (1996). Dry-matter and nitrogen yields of legumes interseeded into sweet corn. Amer. Soc. Hort. Sci. 31:206-208.

Gunasena, H. P. M., R. Sangakkara, and P. Wickremasinghe (1979). Studies on cereal legume intercrop systems. J. Natl. Sci. Counc. Sri Lanka 7(2):85-94.

Gunsolus, J. L. (1986). Reciprocal interference effects between weeds and soybeans (Glycine max) measured by area of influence methodology. Ph.D. Thesis, N. C. State Univ., Raleigh.

Gupta, B. K. and M. Taiyab (1984). Cultural practices for rainfed wheat. Indian Farming 34:15-16.

Gupta, G. P. and B. P. Mathur (1964). Mixed cropping in oilseeds. Indian Oilseeds J. 8:206-213

Gupta, M. L. and O. L. Sharma (1984). Studies on sorghum/pigeonpea intercropping under rainfed conditions. Indian J. Agron. 29:213-217.

Gupta, T. R. (1983). Studies in the border effect in experiments with Indian mustard (Brassica juncea (L.) Czern \& Coss). Madras Agric. J. 70:206-208.

Gupta, U. and P. S. Ramakrishnan (1977). The effect of added salt on competition between 2 ecotypes of Cynodon-Dactylon. Proc. Indian Acad. Sci., Sect. 3, 86(5):275-280.

Gura, S. (1986). A note on traditional food plants in East Africa: their value for nutrition and agriculture. Food Nutr. (FAO) 12:18-26. 
Gutbrod, K. G. (1986). Effect of Azolla on irrigated rice in Brazil. J Agron Crop Sci Z Acker Pflanzenbau 156:37-44.

Gutierrez, V., M. Infante, and A. Pinchinot (1975). Situacion del cultivo de frijol en America Latina. Centro Intl. de Agric. Tropical, Cali, Colombia.

Gutteridge, R. C. (1988). Alley cropping kenaf (Hibiscus cannabinus) with leucaena (Leucaena leucocephala) in south-eastern Queensland. Aust. J. Expl. Agric. 28:481-484.

Gworgwor, N. A. and S. T. O. Lagoke (1992). Weed control in sorghum-groundnut mixture in the simultaneous system of farming in Northern Guinea savanna zone of Nigeria. Trop. Pest Mgt. 38:131-135.

Gysi, C. and F. Keller (1983). Green manure in the greenhouse: a three-year trial with intercropping Trifolium repens, white clover. Plant Soil 74(2):283-286.

Hackett, N. M., D. S. Murray, and D. L. Weeks (1987). Interference of silverleaf nightshade (Solanum elaeagnifolium) on spanish peanuts (Arachis hypogaea L.). Peanut Sci. 14:39-41.

Hackett, N. M., D. S. Murray, and D. L. Weeks (1987). Interference of horsenettle (Solanum carolinense) with peanut (Arachis hypogaea L.). Weed Sci. 35:780-784.

Hackleman, J. C., O. H. Sears, and W. L. Burlison (1928). Soybean production in Illinois. Univ. Illinois Agric. Expt. Sta. Bull. 310:465-531.

Hagood, Jr., E. S., T. T. Bauman, J. L. Williams, Jr., amd M. M. Schreiber (1980). Growth analysis of soybeans (Glycine max) in competition with velvetleaf (Abutilon theophrasti). Weed Sci. 28:729734.

Hagood, Jr., E. S., T. T. Bauman, J. L. Williams, Jr., amd M. M. Schreiber (1981). Growth analysis of soybeans (Glycine max) in competition with jimsonweed (Batura stramonium). Weed Sci. 29:500504.

Hairston, J. E., J. O. Sanford, D. F. Pope, and D. A. Horneck (1987). Soybean-wheat doublecropping: Implications from straw management and supplemental nitrogen. Agronomy J. 79:281-286.

Haizel, K. A. (1972). The productivity of mixtures of two and three species. J. Appl. Ecology 9:601-608.

Haizel, K. A. (1974). The agronomic significance of mixed cropping, 1. Maize interplanted with cowpea. Ghana J. Agric. Sci. 7:169-178.

Haizel, R. A. (1973). Competitive relationship between maize (Zea mays L.) and the weed Rohboellis exaltata Linn. F. Ghana J. Agric. Sci. 6:25-31 (1973).

Hajyiev, O. (1964). Companion cropping of corn. Baky, Azarbaijan dovlat nashriiiaty, $38 \mathrm{pp}$.

Halbrendt, J. M. (1996). Allelopathy in the management of plant-parasitic nematodes. J. Nematology 28:8-14.

Hale, G. A. (1936). A comparison of winter legume green manure amd nitrate of soda for fertilizing cotton. Agronomy J. 28:156-159.

Hall, D. B. (1976). Mixing designs: A general model, simplifications, and some minimal designs. M.S. Thesis, Biometrics Unit, Cornell Univ.

Hall, J. R. (1980). Effect of cultural factors on fescue-Kentucky bluegrass and quality and botanical composition. Proc. 4th Intl. Turfgrass Res. Conf., Ontario, Canada, pp. 367-377.

Hall, M. R., C. J. Swanton, and G. W. Anddrson (1992). The critical period of weed control in grain corn. Weed Sci. 40:441-447.

Hall, R. L. (1974). Analysis of the nature of interference between plants of different species. 1. Concepts and extension of de Wit analysis to examine effects. Aust. J. Agric. Res. 25:739-747.

Hall, R. L. (1974). Analysis of the nature of interference between plants of different species. 2. Nutrient relations in a Nandi Setaria and Greenleaf Desmodium association with particular reference to potassium. Aust. J. Agric. Res. 25:749-756.

Halvorson, G. A. and A. Bauer (1984). Yield and botanical composition of a grass-legume mixture on reclaimed land as affected by $\mathrm{N}$ and $\mathrm{P}$ fertilizer. Agronomy J. 76:355-358.

Hamblin, J. (1975). Effects of environment, seed size and competitive ability on yield and survival of Phaseolus vulgaris genotypes in mixtures. Euphytica 24:435-445.

Hamblin, J. and M. J. de O. Zimmermann (1986). Breeding common bean for yield in mixtures. Plant Breeding Rev. 4:245-272.

Hamblin, J., J. G. Rowell, and R. Redden (1976). Selection for mixed cropping. Euphytica 25:97-106. 
Hamel, C. and D. Smith (1992). Mycorrhizae-mediated 15N transfer from soybean to corn in field-grown intercrops: effect of component crop spatial relationships. Soil Biol. Biochem. 24:499-501.

Hames, R. (1983). Monoculture, polyculture, and polyvariety in tropical forest swidden cultivation Ye'kwana and Yanomamo Gardening, Venezuela. Hum. Ecol. 11(1):13-34.

Hamilton, R. E. (1974). One plus one - double cropping grows in the corn belt. Soil Conserv. 39(7):14:15.

Hamilton, R. I., J. M. Scholl, and A. C. Pope (1969). Performance of three grass species grown alone and with alfalfa under intensive pasture management: Animal and plant responses. Agronomy J. 61:357-361.

Hammel J. E. (1995). Long-term tillage and crop rotation effects on winter wheat production in northern Idaho. Agronomy J. 87:16-22.

Hammond, R. B. and D. L. Jeffers (1990). Potato leafhopper (Homoptera: Cicadellidae) populations on soybean relay intercropped into winter wheat. Environ. Entomol. 19:1810-1819.

Handel, S. N. (1978). The competitive relationship of 3 woodland sedges and its bearing on the evolution of ant dispersal of Carex pedunculata. Evolution 32(1):151-163.

Hanna, M. R., G. C. Kozub, and S. Smoliak (1977). Forage production of sainfoin and alfalfa on dryland in mixed- and alternate-row seedings with three grasses. Can. J. Plant Sci. 57:61-70.

Hanson, R. G., J. A. Stecker, and S. R. Maledy (1988). Effect of soil rotation on the response of sorghum to fertilizer nitrogen. J. Prod. Agric.1:318-321.

Hanson, W. D., C. A. Brim, and K. Hinson (1961). Design and analysis of competition studies with an application to field plot competition in soybean. Crop Sci. 1:255-258.

Haque, F., A. K. Gupta, and Z. Abedin (1987). The logic of intercropping pulse in rainfed Bangladesh: a preliminary assessmentof farmers' views. Australian Centre Intl. Agric. Res. (ACIAR), p. 212.

Hardcastle, J. E. Y. (1959). Development of rice production and research in Nigeria. Trop. Agric. Trin. 36(2):79-178.

Hardin, B. (1996). Intercropping, for more forage and less erosion. Agric. Res. 44(3):1-15.

Hardter, R. (1989). Utilization of nitrogen and phosphorus by intercropping and sole cropping systems of maize (Zea mays L.) and cowpea (Vigna unguiculata L.) on an alfisol in Northern Ghana. Margraf, Weikersheim, FR Germany, 201, xviii pages,

Hardter, R. and W. J. Horst (1991). Nitrogen and phosphorus use in maize sole cropping and maize/cowpea mixed cropping systems on an Alfisol in the northern Guinea Savanna of Ghana. Biol. Fert. Soils 10:267-275.

Hargrove, W. L. (1988). Cropping Strategies for Efficient Use of Water and Nitrogen. ASA Spec. Publ. 51, ASA, CSSA, and SSSA, Madison WI.

Hargrove, W. L. (1991). Cover Crops For Clean Water. Soil Water Conserv. Soc., Ankney, Iowa.

Hargrove, W. L. and W. W. Frye (1987). The need for legume cover crops in conservation tillage production. In The Role of Legumes In Conservation Tillage Systems (ed: J. F. Power). Proc. Natl. Conf. Soil Conserv. Soc., Ankeny, Iowa, pp.1-5.

Hargrove, W. L., J. T. Reid, J. T. Touchton, and R. N. Gallaher (1982). Influence of tillage practices on the fertility status of acid soil double-cropped to wheat and soybeans. Agronomy J. 74:684-687.

Hargrove, W. L., J. T. Touchton, and J. W. Johnson (1983). Previous crop influence on fertilizer nitrogen requirements for double-cropped wheat. Agronomy J. 75:855-859.

Harinikumar, K. M. and D. J. Bagyaraj (1988). Effect of crop rotation on native vesicular mycorrhizel propagules in soil. Plant Soil 110:77-80.

Harinikumar, K. M., D. J. Bagyaraj, and B. C. Mallesha (1990). Effect of intercropping and organic soil amendments on native VA mycorrhizal fungi in an oxisol. Arid Soil Res. Rehabil. 4:193-197.

Harkess, R. D. (1970). Competition between tall fescue and perennial ryegrass in pure and mixed swards under simulated field condition. J. Appl. Ecol. 7:497-506.

Harper, J. L. (1961). Approaches to the study of plant competition. Symp. Soc. Expl. Biol. 15:1-36.

Harper, J. L. (1968). The regulation of numbers and mass in plant populations. In Population Biology and Evolution (ed: E.C. Lewontin). Syracuse Univ. Press, Syracuse, New York, pp 139-158.

Harper, L. A., S. R. Wilkinson, and J. E. Box. Jr. (1980). Row-plant spacing and broiler litter effects on intercropping corn in tall fescue. Agronomy J. 72:5-10.

Harries, J. H., J. Norrington-Davies, and K. R. Howse (1974). Competition for phosphate between a diploid and a tetraploid perennial ryegrass. J. British Grassland Soc. 29:9-16. 
Harrington, L. W. (1993). Wheat and rice in Karnal and Kurukshetra Districts, Haryana, India : Farmers' Practices, Problems, and an Agenda for Action.

Harris, W. (1970). The prospects for mixing varieties of the Lolium multiflorum Lam. I. Perenne I. comples. Proc. XI Intl. Grassland Congress, Univ. Queensland Press, St. Lucia, pp. 651-654.

Harris, W. and A. Lazenby (1974). Competitive interaction of grasses with contrasting temperature responses and stress tolerances. J. Agric. Res. 25:227.

Harris, W. and V. J. Thomas (1973). Competition among pasture plants: III. Effects of frequency and height of cutting on competition between white clover and two ryegrass cultivars. N. Z. J. Agric. Res. 16:49-58.

Hart, R. D. (1974). The design and evaluation of a bean, corn and manioc polyculture cropping system for the humid tropics. Ph.D. Thesis, Univ. Florida, Gainesville.

Hart, R. D. (1975). A bean, corn and manioc polyculture cropping system. I. The effect of interspecific competition on yield. II. A comparison between the yield and economic return from monoculture and polyculture cropping systems. Turrialba 25:294-301 and 377-384.

Harwood, R. R. (1974). The application of science and technology to long range solutions: multiple cropping potentials. Paper, Intl. Conf. Nutrition Agric. Economic Dev. Tropics. INCAP, Guatemala, $29 \mathrm{pp}$.

Harwood, R. R. (1975). Farmer oriented research aimed at crop intensification. Proc. Crops Systems Workshop, IRRI, Los Banos, Philippines. pp. 12-21.

Harwood, R. R. and E. C. Price (1976). Multiple cropping in tropical Asia. In Mulitple Cropping (ed: R. I. Papendick et al.). ASA Spec. Publ. 27, ASA, Madison, WI, pp. 11-40.

Harwood, R. R. and G. R. Banta (1973). The direction and scope of IRRI's multiple cropping program. IRRI, Los Banos, $44 \mathrm{pp}$.

Hasnam and E. Sulistyowati (1989). Performance of cotton varieties under intercropping with mungbean. Indonesian J. Crop Sci. 4:15-25.

Hatfield, J. L. and B. A. Stewart (1994). Crop Residue Management Advances in Soil Science. Lewis Publ., CRC Press, Boca Raton, FL.

Hati, N. and A. K. Ray (1984). Legume-cereal association in pigeon pea-finger millet intercropping system (nitrogen in soil). J. Indian Soc. Soil Sci. 32:183-185.

Hauser, E. W., G. A. Buchanan, and W. J. Ethredge (1975). Competition of Florida beggarweed and sicklepod with peanuts: I. Effects of periods of weed-free maintenance on weed competition. Weed Sci. 23:368-372.

Hawkins, R.(1984). Intercropping maize with sorghum in Central America: A cropping system case study (Farming systems, commodity research). Agric. Syst. 15:79-99.

Hayes, R. M., J. R. Evans, and L. S. Jeffery (1982). Integrated systems for johnsongrass control in soybeans. Proc. South Weed Sci. Soc.. 35:33.

Haylett, D. G. (1961). Green manuring and soil fertility. S. Africa J. Agric. Sci. 4:363-378.

Haynes, R. J. (1980). Competitive aspects of grass-legume association. Adv. Agron. 33:227-261.

Hays, W. M. (1892). Oats sown with field peas. Univ. Minnesota, Agric. Expt. Sta., pp. 36-64.

Haystead, H. and C. Marriott (1978). Fixation and transfer of nitrogen in a white clover-grass sward under hill conditions. Ann. Appl. Biol. 88:453-457.

Haystead, H. and C. Marriott (1979). Transfer of legume nitrogen to associated grass. Soil Biol. Biochem. 11:99-104.

Heady, E. O., R. McAlexander, and W. D. Shrader (1956). Combinations of rotations and fertilization to maximize crop profit in north-central Iowa. Iowa Agric. Expt. Sta. Res. Bull. 439:755-775.

Hedge, D. M. (1977). Phosphorus management in intercropping with pigeonpea (Cajanus cajan (L.) Millsp.) under dryland conditions. Ph.D. Thesis, Indian Agric. Res. Inst., New Delhi.

Hedge, D. M. (1981). Intercropping in medicinal yam with short-duration cowpeas, clusterbean amd kidney-bean Dioscorea floribunda, Vigna cyamopsis, Phaseolus. Indian J. Agric. Sci. 51(4):262265.

Hedge, G. M. and C. S. Saraf (1978). Effect of intercropping and phosphorus fertilation of pigeonpea on fertility status of the soil. Indian J. Agron. 23(4):372-373.

Hedge, G. M. and C. S. Saraf (1978). Light relations in pigeonpea as affected by intercropping and phosphorus fertilization. Indian J. Agron. 23(4):379-380. 
Hedge, G. M. and C. S. Saraf (1979). Economics of phosphorus fertilization of intercropped systems in pigeonpea under dryland conditions. Fert. News 24(3):28-30.

Hedge, G. M. and C. S. Saraf (1979). Effect of intercropping and phosporus fertilization of pigeonpea on soil temperature and soil moisture extraction. Indian J. Agron. 24(2):217-220.

Hedge, G. M. and C. S. Saraf (1982). Effect of intercropping and phosphorus fertilization on nitrogen, phosphorus and potassium concentration and uptake and productivity of pigeonpea (Cajanus cajan (L.) Huth.). Z. Acke. Pflanzenbau J. Agron. Crop Sci. 151(4):302-314.

Heichel, G. (1985). Nitrogen recovery by crops that follow legumes. In Forage Legumes For Energy Efficient Animal Production (ed: R. F. Barnes et al.). Proc. Trilateral Workshop, Palmerston North, N. Z., U. S. Gov. Printing Office, Washington, D. C.

Heichel, G. H. (1978). Stabilizing agricultural energy needs: role of forages, rotations, and nitrogen fixation. J. Soil Water Conserv. 33:279-282.

Heinen, D. A. (1985). The influence of cultivation technique of crucifer intercropping on the population of the sugar beet nematode Heterodera schachtii (Schmidt) as well as on the yield and quality of the sugar beet. Bonn 141, 3 pp..

Helenius, J. (1988). Choice of crop species assemblages as a tool in management. An example of intercropping oats and field beans. Ecol. Bull. 39:97-98.

Helenius, J. (1991). Insect numbers and pest damage in intercrops vs. monocrops: concepts and evidence from a system of faba bean, oats and Rhopalosiphum padi (Homoptera, Aphididae). J. Sustainable Agric. 1:57-80.

Helenius, J. and P. Ronni (1989). Yield, its components and pest incidence in mixed intercropping of oats (Avena sativa) and field beans (Vicia faba). J. Agric. Sci. 61:15-31.

Helsel, Z. R. and W. F. Wedin (1980). Harvested dry matter from single and double-cropping systems. Crop Sci. 21:895-900.

Henderson, J. L. and R. O. Davies (1955). The yield and composition of mixed cereal-legume crops at different stages of growth. Part I. Empire J. Expl. Agric. 23:131-144.

Henry, W. T. (1988). Interference between soybeans, common cocklebur and jimsonweed under Indiana field conditions. Ph.D. Thesis, Purdue Univ., Lafayette.

Henzell, E. F. (1962). Nitrogen fixation and transfer by some tropical and temperate pasture legumes in sand culture. Aust. J. Expl. Agric. Animal Husb. 2:132-140.

Henzell, E. F. (1970). Problems in comparing the economics of legume-based and nitrogen fertilized pasture systems. Proc. Intl. Grassl. Congr. 11:A112-A120.

Herath, H. M. G. (1987). Some socioeconomic constraints of legume cultivation in Sri Lanka. Australian Centre Intl. Agric. Res. (ACIAR), pp. 212-213.

Herbek, J. H. and M. J. Bitzer (1988). Soybean production in Kentucky. Part 3: Planting practices and double cropping. Kentucky Agric. Expt. Sta. Bull. AGR-130.

Herbert, S. J., D. H. Putman, M. I. Poos-Floyd, et al. (1984). Forage yield of intercropped corn and soybean in various planting patterns. Agronomy J. 76:507-510.

Hernandez S., R. (1975). La asociacion papa-maiz-frijol una forma de use intensive y economico de los recursos de la agricultura de minifundio. Fitotecnia Latinoamericans 11(1):67-71.

Herrera, W. T. and R. R. Harwood. (1973). Crop interrelationships in intensive cropping systems. IRRI Saturday Seminar, IRRI, Los Banos, Philippines.

Herridge, D. F. (1982). Crop rotations involving legumes. In Nitrogen Fixation in Legumes (ed: J. M. Vincent). Academic Press, Sydney, pp.253-261.

Hess, T. M. and A. K. Grema (1994). The impact of changing rainfall patterns on the efficiency of rainfall utilisation in pearl millet-cowpea intercropping systems in North-East Nigeria. Aspects Applied Biol. 38:231-238.

Hesterman, O. B. (1988). Exploiting legumes for nitrogen contribution in cropping systems. In Cropping Systems For Eficient Use of Water and Nitrogen (ed: W. L. Hargrove). ASA Spec. Publ. 51, ASA, CSSA, and SSSA, Madison, WI., pp. 155-166.

Hesterman, O. B., C. C. Sheaffer, and E. I. Fuller (1986). Economic comparisons of crop rotations including alfalfa, soybean, and corn. Agronomy J. 78:24-28.

Hesterman, O. B., C. C. Sheaffer, D. K. Barnes, et al. (1986). Alfalfa dry matter and nitrogen production and fertilizer nitrogen response in legume-corn rotations. Agronomy J. 78:19-23. 
Hesterman, O. B., M. P. Russelle, C. C. Sheaffer, and G. H. Heichel (1987). Nitrogen utilization from fertilizer and legume residues in legume-corn rotations. Agronomy J. 79:726-731.

Hesterman, O. B., T. S. Griffin, P. T. Williams, et al. (1992). Forage legume-small grain intercrops: Nitrogen production and response of subsequent crop. J. Prod. Agric. 5:340-348.

Hewitt, G. B., A. C. Wilton, and R. J. Lorenz (1982). The suitability of legumes for rangeland interseeding and as grasshopper food plants. J. Range Mgt. 35:653-656.

Hewstone M., C. and O. Inostroza U. (1979). Los cambios en la respuesta del rendimiento del trigo producidos por diferentes rotaciones de cultivo. In Analisis del Rendimiento de Variedades Comerciales de Trigo y de Algunos Factores del Medio Ambiente que lo Afectan en el Sur de Chile (ed: C. Hewstone M.). Inst. Investl Agrop. Estacion Expl. Carrillanca, Temuco, Chile, pp. 72-78.

Hickisch, B., G. Muller, Jr., and W. Heisig (1984). Influence of weather conditions and crops on soil biological efficiency. 4. Comparison of the order of precedence made between cultivated plants in the second year of growing with 16 test-factors considered. Zentralbl. Mikrobiol. 139:511-517.

Hicks, D. R. and R. H. Peterson (1981). Effect of corn variety and soybean rotation on corn yield. Proc.36th Annual Corn Sorghum Res. Conf., Amer. Seed Trade Assoc., Washington, D. C., pp. 8994.

Hiebsch, C. (1978). Comparing intercrops with monocultures. Agronomic Economic Res. Soils Tropics, 1976-1977 Annual Report, North Carolina State Univ., Raleigh, pp.187-200.

Hiebsch, C. K. and R. E. McCollum (1980). Effects of removing corn from a corn-soybean intercrop upon sōybean yields and yield equivalency ratios. Agronomic-Economic Res. on Soils in the Tropics, Annual Report 1978-79, North Carolina State Univ., Raleigh, pp. 224-263.

Hiebsch, C. K. and R. E. McCollum (1987). Area-x-time equivalency ratio: A method for evaluating the productivity of intercrops. Agronomy J. 79:15-22.

Hiebsch, C. K., F. Tetio-Kagho, A, M. Chirembo, and F. P. Gardner (1995). Plant density and soybean maturity in a soybean-maize intercrop. Agronomy J. 87:965-969.

Higgins, J. M., T. Whitwell, and J. E. Toler (1988). Herbicide efficacy for various application times in doublecrop wheat and soybean. Agronomy J. 80:475-478.

Higgs, R. L., A. E. Peterson, and W. H. Paulson (1990). Crop rotations: Sustainable and profitable. J. Soil Water Conservation 45:68-70.

Higgs, R. L., W. H. Paulson, J. W. Pendleton, et al. (1976). Crop rotation and nitrogen. Wisc. Agric. Expt. Sta. Bull. R2761.

High, Jr., J. W., L. M. Safley, O. H. Long, et al. (1965). Combinations of orchardgrass, fescue and ladino clover pastures for producing yearling steers. Tennessee Agric. Expt. Sta. Bull. 388.

Higley, L. G. amd L. P. Pedigo (1991). Soybean yield responses and intraspecific competition from simulated seedcorn maggot injury. Agronomy J. 83:135-139.

Hikam, S., C. T. MacKown, C. G. Poneleit, and D. F. Hildebrand (1991). Growth and N accumulation in maize and winged bean as affected by $\mathrm{N}$ level and intercropping. Ann. Bot. (London) 68:17-22.

Hildebrand, P. E. (1976). Multiple cropping systems and dollars and "sense". In Multiple Cropping (ed: R. I. Papendick et al.). Spec. Publ. 27, ASA, Madison, WI, pp. 347-372.

Hildebrand, P. E. and E. C. French (1974). Un sistema Salvadoreno de multicultivos: su potencial y su problemas. Min. de Agric. y Granad. CENTA, San Tecla, El Salvador. 29 p.

Hill, J. and Y. Shimamoto (1973). Methods of analyzing competition with special reference to herbage plants. I. Establishment. J. Agric. Sci. (Camb.) 81:77-89.

Hill, L. V. and P. W. Santelmann (1969). Competitive effects of annual weeds on spanish peanuts. Weed Sci. 17:1-2.

Hinson, K. and W. D. Hanson (1962). Competition studies in soybean. Crop Sci. 2:117-123.

Hobbs, J. A. (1971). Yields and protein content of crops in various rotations. Agronomy J. 63:832-836.

Hocking, D. )1986). Some principles of crop complementarity in agroforestry systems. In Agroforestry Systems, A New Challenge (ed: P.K. Khosla, S. Puri, and D.K. Khurana). Indian Soc. Tree Sci., pp. 39-42.

Hodgson, G. L. and G. E. Blackman (1956). An analysis of the influence of plant density on the growth of Vicia faba. I. The influence of density on the pattern of development. J. Expl. Bot. 7:147-165. 
Hodgson, J., W. G. Souter, G. F. Davies, and S. Jones (1983). Diet composition and herbage intake in sheep grazing mixed grass-clover swards. Grass Forage Sci. 38:151-152.

Hoefer, R. H., G. A. Wicks, and O. C. Burnside (1981). Grain yields, soil water storage, and weed growth in a winter wheat-corn fallow rotation. Agronomy J. 73:1066-1071.

Hoekstra, G. J., L. W. Kannenberg, and B. R. Christie (1985). Grain yield comparison of pure stands and equal proportion of seven hybrids of maize. Can. J. Plant Sci. 65:471-479.

Hoffman, F. L., E. E. Regnier, and J. Cardina (1993). Weed and corn (Zea mays L.) responses to a hairy vetch (Vicia villosa) cover crop. Weed Technol. 7:594-599.

Hoffman, M. P., H. D. Thurston, and M. E. Smith (1993). Breeding for resistance to insects and plant pathogens. In Crop Improvement for Sustainable Agriculture (ed: M. B. Callaway and C. A. Francis), Univ. Nebraska Press, Lincoln and London, pp. 79-99.

Holderbaum, J. F., A. M. Decker, J. J. Meisinger, et al. (1990). Harvest management of a crimson clover cover crop for no-tillage corn production. Agronomy J. 82:918-923.

Holderbaum, J. F., A. M. Decker, J.J. Meisinger, et al. (1990). Fall-seeded legume cover crops for notillage corn in the humid east. Agronomy J. 82:117-124.

Holdridge, L. R. (1959). Ecological indications of the need for a new approach to tropical land use. Econ. Bot. 13:271-280.

Holt, N. W. and T. Lawrence (1994). Pasture production of Russian wild ryegrass alone or in mixtures with Dahurian wild ryegrass or slender wheatgrass. Can. J. Plant Sci. 74:103-107.

Hong, C. K., S. Y. Lee, H. K. Min, et al. (1985). Effect of intercropping with corn on yield of potato, wild garlic and wild lettuce. Nongsa Sihom Yon'gu Pogo Nongki Nongka Nongkyong Res. Rep. Rural Dev. Admin. 27:140-147.

Hood, C. E., A. Khalilian, J. H. Palmer, et al. (1990). Doublecropping interseeding system for wheat, soybean, and cotton. ASAE paper no. 90-1527, ASAE, St. Joseph, MI.

Hood, C. E., A. Khalilian, J. H. Palmer, et al. (1991). Double-cropping interseeding system for wheat, soybeans, and cotton. Appl. Eng. Agric. 7:530-536.

Hook, J. E. and G. J. Gascho (1988). Multiple cropping for efficient use of water and nitrogen. ASA Spec. Publ. 51, Madison, WI, pp. 7-20.

Hoopper III, J. R., V. E. Ross, and D. E. McCloud (1975). Double cropping rice under natural rainfall in central Luzon, Philippines. Proc. Soil and Crop Sci. 34:162-167.

Horiuchi, T. (1985). Growth and yields of field crops in intercropping culture. Jap. Agric. Res. Q. 19:1-6.

Horwith, B. (1985). A role for intercropping in modern agriculture. BioScience 35:286-291

Hou, C. T. and P. C. Lo (1978). Chung-kuo Nung Yeh K'o Hsueh. Peking, Nung yeh ch'u panshe. No. 3. pp. 29-35.

Houser, E. W., C. C. Dowler, M. D. Jellum, and S. R. Cecil (1974). Effects of herbicide crop rotation on nutsedge, annual weeds and crops. Weed Sci. 22:172-176.

Hoveland, C. S. and M. D. Richardson (1992). Nirogen fertilization of tall fescue-birdsfoot trefoil mixtures. Agronomy J. 84:621-627.

Hoveland, C. S., M. W. Alison, Jr., G. V. Calvert, et al. (1986). Perennial cool-season grass-legume mixtures in north Georgia. Georgia Agric. Expt. Sta. Res. Bull. 339.

Hoveland, C. S., M. W. Allison, R. F. McCormick, Jr. et al. (1981). Seeding legumes into tall fesue sod. Ala. Agric. Expt. Sta. Bull. 531.

Hoveland, C. S., R. F. McCormick, E. L. Carden, et al. (1978). Maintaining tall fescue stands in association with bahiagrass. Agronomy J. 70:649-652.

Hoveland, C. S., R. G. Durham, and J. H. Bouton (1997). Tall fescue response to clipping and competition with no-till seeded alfalfa as affected by fungal endophyte. Agronomy J. 89:119-125.

Hovermale, C. H. (1983). The effect of cover crop, tillage method, and residue management on soybean yield in South Mississippi. Mississippi State Univ. Res. Rep. Vol 8, no. 13, MS State Univ., State College.

Howard, D. D. and G. Lessman (1991). Nitrogen fertilization of wheat double-cropped following grain sorghum in a no-tillage system. Agronomy J. 83:208-211.

Hoyt, P. B. and R. H. Leitch (1983). Effects of forage legume species on soil moisture, nitrogen and yield of succeeding barley crops. Can. J. Soil Sci. 63:125-136. 
Huang, H. Y. and F. Ao (1982). Lin Yeh Hsueh Sci. Silvae Sin. Peking. K'o hsueh chu panshe 18(3):335339.

Huber, D. M. and T. S. Abney (1986). Soybean allelopathy and subsequent cropping. J. Agric. Crop Sci. 157:73-78.

Hulet, H. and P. Gosseye (1986). Effect of intercropping cowpea on dry-matter and grain yield of millet in the semi-arid zone of Mali. In Potentials of Forage Legumes in Farming Systems of Sub-Saharan Africa (ed: I. Haque et al.). Proc. Workshop ILCA, Addis Ababa, Ethiopia, pp. 379-396.

Hulugalle, N. R. and H. C. Ezumah (1989). Effect of cassava-based cropping system and rotation on soil physical properties of an Alfisol in Southwestern Nigeria. Proc. $6^{\text {th }}$ Intl. Conserv. Conf., Addis Ababa.

Hulugalle, N. R. and H. C. Ezumah (1991). Effects of cassava-based cropping systems on physicochemical properties of soil and earthworm casts in a tropical Alfisol. Agric. Ecosyst. Environ. 35:55-63.

Hulugalle, N. R. and R. Lal (1986). Soil water balance of intercropped maize and cowpea grown in a tropical hydromorphic soil in western Nigeria. Agronomy J. 78:86-90.

Hulugalle, N. R. and S. T. Willatt (1987). Seasonal variation in the water uptake and leaf water potential of intercropped and monocropped chillies. Expl. Agric. 23:273-282.

Hunt, K. L. and J. H. Dunn (1993). Compatibility of Kentucky bluegrass and perennial ryegrass with tall fescue in transition zone turfgrass mixtures. Agronomy J. 85:211-215.

Hunter, J. V. and J. W. Avault, Jr. (1980). Polyculture of prawns, Macrobrachium rosenbergii, and channel catfish fingerlings, Ictalurus punctatus, in Louisiana. Proc. La. Acad. Sci. 43:95-103.

Huntington, T. G., J. H. Grove, and W. W. Frye (1985). Release and recovery of nitrogen from winter anual cover crops in no-till corn production. Commun. Soil Sci. Plant Anal. 16:193-211.

Hussein, M. Y. and N. A. Samad (1993). Intercropping chilli with maize or brinjal to suppress populations of Aphis gossypii Glov., and transmission of chilli viruses. Intl. J. Pest Mgt. 39:216222.

Huxley, P. A. (1986). Rationalising research on hedgerow intercropping. an overview. $1^{\text {st }}$ revision. Nairobi, ICRAF 148, 3 pp.

Huxley, P. A. and Z. Maingu (1978). Use of a systematic spacing design as an aid to the study of intercropping: some general considerations. Expl. Agric. 14:49-56.

Hyder, D. N. and F. A. Sneva (1963). Studies of six grasses seeded on sagebrush-bunchgrass range. Oregon Agric. Expt. Sta. Tech. Bull. 71.

IBGE. (1956). Recenseamento geral de Brasil VI - 1950, Censo Agricola: serie Nacional 2. Servico national de recenseamento. Inst. Brasileira Geografia Estatistica (IBGE). Rio de Janeiro, Brazil, $135 \mathrm{pp}$.

IBGE. (1970). Sinopse preliminar do censo agropecuario. VIII Recenseamento geral: Brasil e unidades da federacao. Brasilia, Brazil, 599 pp.

Ibrahim, A. E. S. (1995). Summer forage yield of irrigated Sudan grass (Sorghum sudanese (Piper) Stapf)) and phillipesera (Vigna trilobata Verd.) in monoculture and mixtures. Trop. Sci. 35:1-8.

Ibrahim, A. F., K. M. Alrawi, and A. A. Salman (1977). Performance of corn (Zea mays L.) and soybean (Glycine $\max$ L.) Merr.) under intercropping in alternative rows and at different plant population densities. Z. Acker Pflanzenbau. 145(3):224-237.

ICRISAT (Intl. Crops Res. Inst. for the Semi-Arid Tropics) (1976). Annual Report for 1976. IRRI, Los Banos, Philippines, $352 \mathrm{pp}$.

Idowu, A. A. (1989). Assessing advantages of intercropping in nematode management. Agroforestry practices of Gujarat state. Intl. Nematol. Network Newsl. 6:31-33.

Ifenkwe, O. P., S. O. Odurukwe, J. C. Okonkwo, and H. N. Nwokocha (1989). Effects of maize and potato populations on tuber and grain yields, net income and land equivalent ratios in potato/maize intercropping. Trop. Agric. 66:329-333.

Igbokwe, M. C. A. O. B., T. C. Ndubuizu, and E. E. Umana (1984). Intercropping cocoyams with plantain: effects on the yield and disease of cocoyams. In Tropical Root Crops: Production and Uses in Africa (ed: E.R. Terry. et al.), Proc. $2^{\text {nd }}$ Triennial Symp. Intl. Soc. Trop. Root Crops, Douala, Cameroon, pp. 182-184.

Igbozurike, M. V. (1971). Ecological balance in tropical agriculture. Geog. Rev. 61:519-527. 
IITA (International Institute of Tropical Agriculture). (1974-1977). Farming Systems Program. IITA 1974-1977 Annual Reports, Ibadan, Nigeria.

IITA Annual Report $(1981,1983)$. International Inst. Tropical Agric., Ibadan, Nigeria.

Ikeorgu, J. E. G. and S. O. Odurukwe (1992). Increasing the productivity of cassava/maize intercrops with groundnuts (Arachis hypogaea L.). Trop. Agric. 67:164-168.

Ikeorgu, J. E. G. and S. O. Odurukwe (1994). Productivity of Nigeria's elite cassava cultivars grown in mixture with contrasting maize genotypes. Acta Hort. Nov., 380:211-213.

Ikeorgu, J. E. G., T. A. T. Wahua, and H. C. Ezumah (1984). Crop performance in complex mixtures: melon and okra in cassava maize mixture. In Tropical Root Crops: Production and Uses in Africa (ed: E.R. Terry. et al.), Proc. $2^{\text {nd }}$ Triennial Symp. Intl. Soc. Trop. Root Crops, Douala, Cameroon, pp. 63-66.

Ikeorgu, J. E. G., T. A. T. Wahua, and H. C. Ezumah (1989). Effects of melon (Citrullus lanatus Thunb.) and okra (Abelmoschus esculentus (L.) Moench) on the soil moisture and leaf water status of intercropped cassava/maize in Nigeria. Trop. Agric. 66:78-82.

Imbamba, S. K. and E. M. W. Akunda (1985). Diurnal course of light interception by a groundnut crop grown in association with maize. J. Appl. Microbiol. Biotechnol. 1:45-54.

Innis, D. Q. (1976). What can we learn about intercropping vegetables and field crops from tropical farmers? Org. Gard. Farm. 23(2): 92-93.

Innis, D. Q. (1983). Aspects of Jamaican post-industrial agriculture. J. Geogr. 82:222-226.

International Rice Research Institute (1982). Cropping Systems in Asia. IRRI, Los Banos, Philippines.

Intl. Rice Res. Inst. (1985, 1986, 1987) Annual Reports for 1984, 1985, and 1986. IRRI, Los Banos, Philippines.

IRA, IRZ (1987). Collaborative study into maize based crop associations in farming systems of Ndop Plain. Cameroon, MIDENO, $32 \mathrm{pp}$.

Iragavarapu, T. K. and G. W. Randall (1996). Border effects on yields in a strip-intercropped soybean, corn, and wheat production system. J. Production Agric. 9:101-107.

IRRI (Intl. Rice Res. Inst.). (1972-1975). Multiple cropping. IRRI Annual Reports for 1972-1975. IRRI, Los Banos, Philippines.

IRRI-IDRC-UPLB. (1976). Varietal screening for intensive cropping. Progress Report II, IRRI-IDRCUPLB project. IRRI, Laguna, Philippines.

Irvine, F. R. (1953). West African Agriculture, $2^{\text {nd }}$ Edition, Oxford Univ. Press, London. 260 pp.

Irvine, F. R. (1959). A Textbook of West African Agriculture, Soil and Crops. Oxford Univ. Press, London.

Irvine, F. R. (1969). West African Agriculture. Vol. 2. Oxford Univ. Press, London.

Isfan, D. (1986). Sharing the available fertilizer rate between two crops in a linited-capital situation. Agronomy J. 78:346-347.

Iso, Eikichi. (1954). Rice and Crops in its Rotation in Subtropical Zones. Japan FAO Assoc., Tokyo, 611 pp.

Ivens, G.W. and F. Mlowe (1980). A study of competition between seedlings of gorse Ulex europaeus and perennial rye grass Lolium perenne cultivar Grasslands-Nui by means of a replacement series experiment. Weed Res. 20(3):183-192.

Izaurralde, R. C., D. S. Chanasyk, and N. G. Juma (1994). Soil water under conventional and alternative cropping systems in cryoboreal subhumid central Alberta. Can. J. Soil Sci. 74:85-92.

Izaurralde, R. C., M. Choudhary, N. G. Juma, et al. (1995). Crop and nitrogen yield in legume-based rotations practiced with zero tillage and low-input methods. Agronomy J. 87:958-964.

Izaurralde, R. C., N. G. Juma, and W. B. McGill (1990). Plant and nitrogen yield of barley-field pea intercrop in Cryoboreal-subhumid Central Alberta. Agronomy J. 82:295-301.

Izaurralde, R. C., N. G. Juma, W. B. McGill, et al. (1993). Performance of conventional and alternative cropping systems in cryoboreal subhumid central Alberta. J. Agric. Sci. 120:33-41.

Izaurralde, R. C., W. B. McGill, and N. G. Juma (1992). Nitrogen fixation efficiency, interspecies N transfer and root growth in barley-field pea intercrop on a Black Chernozemic soil. Biol. Fert. Soils 13: 11-16.

Izaurralde, R. C., Y. Feng, J. A. Robertson, et al. (1995). Long-term influence of cropping systems, tillage methods, and $\mathrm{N}$ sources on nitrate leaching. Can. J. Soil Sci 75:(in press). 
Jackman, R. H. and M. C. H. Mount (1972). Competition between grass and clover for phosphate I \& II. N. Z. J. Agric. Res. 15:653-675.

Jackobs, J. A. (1966). The role of short-lived species in seeding mixtures for grasslands. Proc. 9th Intl. Grassland Congress, Alarico Limitada, Sao Paulo, pp. 413-416.

Jackobs, J. A. (1967). One hundred forage seeding mixtures. Agronomy J. 59:435-438.

Jackson, L. E., L. J. Wyland, amd L. J. Stivers (1993). Winter cover crops to minimize nitrate losses in intensive lettuce production. J. Agric. Sci. 121:55-62.

Jadhav, A. S. and P. N. Kalbhor (1983). Intercropping of safflower and gram in ratoon sorghum with different planting patterns under protective irrigations. II. Cicer arietinum, Carthamus tinctarius J. Maharashtra Agric. Univ. Pune 8(1):66-68.

Jadhav, A. S. and S. V. Deshpande (1983). Intercropping of moong and groundnut in sorghum with different planting patterns under rainfed conditions. I. Phaseolus aureus, peanut, Arachis hypogaea. J. Maharashtra Agric. Univ. Pune 8(1):63-65.

Jafri, S. M. H. and S. N. Pandit (1986). An appraisal of potassium contribution from exchangeable and non-exchangeable sources to sugarcane with cowpea as intercrop. J. Potassium Res. 2:108-111.

Jagannath, M. K. and N. Sunderaraj (1987). Productivity equivalent ratio and statistical testing of its advantage in intercropping. J. Indian Soc. Agric. Statistics 39:289-300.

Jain, K. C. and D. G. Faris (1987). The potential of medium-duration pigeonpea. Australian Centre Intl. Agric. Res. (ACIAR), p. 238.

Jain, K. C. and M. R. Bajpai (1971). Economics of the common mixture of mixed cropping in the semiarid tract of central Rajasthan. Ann. Arid-Zone 10(4):251-254.

Jain, S. C., K. - S. Yadav, and V. N. Shroff (1982). Yield and economic parameters of hybrid cotton in mixed biomass and manoeuvred geometrical systems (Intercropping). Cotton Dev. 12(1/2):17-21.

Jain, T. C. (1978). Barley or wheat as intercrop with potato. Indian Farming 28(3):7-9.

Jain, T. C. and C. Nageswara Rao (1980). Note on a new approach to analysis of yield data in intercropping system. Indian J. Agric. Sci. 50(1/2):970-972.

Jalloh, A., M. T. Dahniya, and H. C. Ezumah (1994). Production of cassava-rice intercrop as influenced by cassava variety and time of introducing rice into cassava. Acta Hort. 380:200-204.

Jama, B., B. Macklin, K. Reshid, and A. Getahun (1989). Intercropping experiments with Casuarina equisetifolia in Kenya. Nitrogen Fixing Tree Res. Rep. 7:83-85.

James, K. I. and R. R. Nair (1977). A novel strategy of intercropping in traditional lowland rice fields to maximize food production. Int. Rice Res. Inst. Newsl. 2( 5):26.

Jameson, J.-D. (Ed.) (1970). Agriculture in Uganda. Uganda Government Ministry Agric. For., Oxford Univ. Press, London.

Jana, B. B. and S. K. Roy (1983). Estimates of microbial populations involved in the $\mathrm{N}$ nitrogen cycle and their activity in water and sediments of fish farming ponds under mono- and polyculture systems in India. Int. Rev. Gesamten Hydrobiol. 68(4):581-590.

Jana, B. B. and S. K. Roy (1983). Growth of fishes in polyculture ponds as a function of numbers of bacteria involved in the nitrogen cycle. Hydrobiol J. 19(2):90-92.

Jana, B. B. and U. K. De (1983). Primary productivity of phytoplankton, environmental covariates and fish growth in West Bengal ponds under a polyculture system. Int. Rev. Gesamten Hydrobiol. 68(1):45-58.

Jana, B. B., and Patel, G. N. (1983). Relationship between the nitrification and denitrification rates and the fish growth in fish ponds under polyculture system. Pol. Arch. Hydrobiol. Warszawa. Panstowowe Wydawn. Naukowe. 30(1):65-68.

Janardhanan, K. V. (1982). Intercropping in cotton with three rows of blackgram. Cotton Dev. 12(1/2):39-32.

Jannink, J-L, M. Liebman, and L. C. Merrick (1996). Biomass production and nitrogen accumulation in pea, oat, and vetch green manure mixtures. Agronomy J. 88:231-240.

Janson, C. G. and T. L. Knight (1973). Establishment of lucerne with cover crops under different soil moisture conditions. J. Expl. Agric. 1:243-251.

Janzen, H. H. (1987). Effect of fertilizer on soil productivity in long-term spring wheat rotations. Can. J. Soil Sci. 67:165-174. 
Janzen, H. H. (1987). Soil organic characteristics after long-term cropping to various spring wheat rotations. Can. J. Soil Sci. 67:845-856.

Jawandas J. S. Intercropping the orchards. Prog. Farm. 14(9):4-5.

Jayaraj, S. (1986). Pest and disease management rop ecosystem approach. In Pest and Disease Management: Oilseeds, Pulses, Millets and Cotton (ed: S. Jayaraj). Tamil Nadu Agric. Univ., pp. 208-216.

Jaynes, D. B. and T. S. Colvin (1997). Spatiotemporal variability of corn and soybean yield. Agronomy J. 89:30-37.

Jedel, P. E. and D. F. Salmon (1995). Forage potential of spring and winter cereal mixtures in a shortseason growing area. Agronomy J. 87:731-736.

Jeffers, D. L. (1982). Use of a growth retardant for soybeans intercropped in winter wheat. Proc. Plant Growth Regul. Soc. Amer. 9:131-136.

Jeffers, D. L. (1984). A growth retardant improves performance of soybeans relay intercropped with winter wheat. Crop Sci. 24:695-698.

Jeffers, D. L. (1986). Evaluation of four growth retardants for soybeans relay intercropped with winter wheat. Proc. Annu. Meet. Plant Growth Regul. Soc. Amer., The Society, Issue 13, pp. 36-40.

Jeffers, D. L. and G. B. Triplett, Jr. (1979). Management needed for relay intercropping soybeans and wheat. Ohio Rep. Res. Dev. Agric. Home Econ. Nat. Resource Wooster, The Center 64(5):67-70.

Jeffers, D. L. and G. B. Triplett, Jr.(1979). Management needed for relay intercropping soybeans and wheat. Ohio Rep. 64:67-70.

Jeffers, D. L., G. B. Triplett, and J. E. Beuerlein (1973). Management is the key to success--doublecropped soybeans. Ohio Rep. Res. Dev. 58:67-69.

Jellum, E. J. and S. Kuo (1990). Effects of corn row pattern and intercropping with legumes on silage corn. J. Prod. Agric. 3:545-551.

Jena, D. and C. Misra (1988). Effect of crop geometry (row proportions) on the water balance of the root zone of a pigeonpea and rice intercropping system. Expl. Agric. 24:385-391.

Jennings, P. R. and J. De Jesus (1968). Studies on competition in rice. I. Competition in mixtures of varieties. Evolution 22:119-124.

Jensen, E S. (1996). Barley uptake of N deposited in the rhizosphere of associated field pea. Soil Biol. Biochem. 28:159-168.

Jensen, E. H., S. R. Lewis, E. R. Chouinard, and L. D. Massman (1989). Oat performance in western and central Nevada. Fact Sheet Coll. Agric. Univ. Nev-Reno, The College, 89-01, 4 pages.

Jensen, E. S. (1986). Intercropping faba bean with maize in Denmark. FABIS (Faba Bean Inf. Serv.) Newsl. Issue 16, pp. 25-28.

Jensen, H. E. et al.(1994). Proc. Int. Soil Tillage Res. Org. (ISTRO), 13th., Aalborg, Denmark.

Jensen, N. F. (1952). Intervarietal diversification in oat breeding. Agronomy J. 44:30-34.

Jensen, N. F. (1965). Multiline superiority in cereals. Crop Sci . 5:566-568.

Jensen, N. F. and W. T. Federer (1964). Adjacent row competition in wheat. Crop Sci. 4:641-645.

Jensen, N. F. and W. T. Federer (1965). Competing ability in wheat. Crop Sci . 5:449-452.

Jereza, H. C. and S. K. De Datta (1976). Weed shifts and weeding management in lowland rice. Saturday Seminar, IRRI, Los Banos, Laguna, Philippines.

Jodha, N. S. (1979). Intercropping in traditional farming systems. Proc. Intl. Workshop on Intercropping, ICRISAT, Hyderabad, India, pp. 282-291.

Johansen, C. and P. C. Kerridge (1979). Nitrogen fixation and transfer in tropical legume-grass swards in southeastern Queensland. Trop. Grassl. 13:165-170.

John, P. S. (1987). Nitrogen economy in rice-based cropping systems through cowpea green manure, crop residue, and fertilizer nitrogen management. Ph.D. Thesis, Indian Agric. Res. Inst., New Delhi, India.

John, P. S., R. K. Pandey, R. J. Buresh, and R. Prasad (1989). Lowland rice response to urea following three cowpea cropping systems. Agronomy J. 81:853-857.

Johnson, B. J. (1986). Response to vertical mowing and ethofumesate treatments for annual bluegrass control in burmudagrass turf. Agronomy J. 78:495-498. 
Johnson, J. R. and J. T. Nichols (1969). Production, crude protein and use of 11 irrigated grasses and alfalfa-grass combinations on clay soils in western South Dakota. South Dakota Agric. Expt. Sta. Bull. 555.

Johnson, K. D., V. L. Lechtenberg, J. J. Vorst, and K. S. Hendrix (1982). Indirect estimation of grasslegume ratios in mixed swards. Agronomy J. 74:1089-1091.

Johnson, M. W. and R. F. L. Mau (1986). Effects of intercropping beans and onions on populations of Liriomyza spp. and associated parasitic Hymenoptera. Proc. Hawaii Entomol. Soc. 27:95-103.

Johnson, N. C., F. L. Pfleger, R. K. Crookston, et al. (1991). Vesicular-arbuscular mycorrhizae respond to corn-soybean cropping history. New Phytol. 117:657-663.

Johnson, W. C. and H. D. Coble (1986). Crop rotation and herbicide effects on the population dynamics of two annual grasses. Weed Sci. 34:452-456.

Johnston, B. F. (1958). The Staple Food Economics of Western Tropical Africa. Stanford Univ. Press, Stanford.

Jones, O. R. and T. W. Popham (1997). Cropping and tillage systems for dryland production in the Southern High Plains. Agronomy J. 89:222-232.

Jones, T. A. (1986). Compatibility of reed canarygrass with alfalfa and birdsfoot trefoil. Ph.D. Thesis, Iowa State Univ., Ames.

Jones, T. A., I. T. Carlson, and D. R. Buxton (1988). Persistence of reed canarygrass clones in binary mixtures with alfalfa and birdsfoot trefoil. Agronomy J. 80:967-970.

Jones, T. A., I. T. Carlson, and D. R. Buxton (1988). Reed canarygrass binary mixtures with alfalfa and birdsfoot trefoil in comparison to monocultures. Agronomy J. 80:49-55.

Jones, W. O. (1959). Manioc in Africa. Stanford Univ. Press, Stanford.

Jones, W. O. (1965). Environment, technical knowledge and economic development in Tropical Africa. In Ecology And Economic Development in Tropical Africa (ed: D. Brokensha). Inst. Intl Studies. Res. Series No. 9, Univ. California, Berkeley, pp. 29-48.

Jordan, D., C. W. Rice, and J. M. Tiedje (1993). The effect of suppression treatments on the uptake of $15 \mathrm{~N}$ by intercropped corn from labeled alfalfa (Medicago sativa). Biol. Fertility Soils 16:221-226.

Jordan, H. D., et al. (1966). Annual Report of the west African Rice Research Station, Rokupr, Sierra Leone.

Joseph, N. S. (1987). An ex-ante economic appraisal of mono-cropping, mixed cropping and intercropping of annual and perennial crops. Agric. Syst. 24:67-80.

Joshi, R. C., D. D. Haokip, and K. N. Singh (1994). Effect of green manuring on the physical properties of soil under a rice-wheat cropping system. J. Agric. Sci. 122:107-113.

Joshi, S. M. and H. V. Joshi (1965). Mixed cropping of groundnut-cotton under irrigated conditions in Saurashtra. Indian Oilseed J. 9:244-248.

Jung, G. A. and J. A. Shaffer (1993). Component yields and quality of binary mixtures of lucerne and perennial , Italian or short rotation hybrid ryegrass. Grass Forage Sci. 48:118-125.

Jung, G. A., J. A. Shaffer, and J. L. Rosenberger (1991). Sward dynamics and herbage nutritional value of alfalfa-ryegrass mixtures. Agronomy J. 83:786-794.

Jung, G. A., J. A. Shaffer, and J. R. Everhart (1996). Harvest frequency and cultivar influence on yield and protein of alfalfa-ryegrass mixtures. Agronomy J. 88:817-822.

Jung, G. A., J. L. Griffin, R. E. Kocher, et al. (1985). Performance of switchgrass and bluestem cultivars mixed with cool-season species. Agronomy J. 77:846-850.

Jung, G. A., L. L. Wilson, P. J. Le Van, et al. (1982). Herbage and beef production from ryegrass-alfalfa and orchädgrass-alfalfa pastures. Agronomy J. 74:937-942.

Juo, A. S. R. and H. C. Ezumah (1990). Mixed root crop ecosystems in the western regions of SubSaharan Africa. In Food Crop Ecosystems of the World (ed: C. J. Pearson), Elsevier, Amsterdam.

Just, R. E. and W. Candler (1983). Production functions and rationality of mixed cropping: the Nigerian case. Work pap Giannini Found. Agric. Econ. Berkeley No. 247. 25 p.

Justus, M. and U. Kopke (1995). Strategies to reduce nitrogen losses via leaching and to increase precrop effects when growing faba beans. Biol. Agric. Hort. 11:145-155.

Kachapur, M. D. and V. B. Nadagouda (1980). Studies on intercropping with niger (Guizotia abyssinica Cass). Mysore J. Agric. Sci. 14:31-33. 
Kahlon, A. S. and D. D. Gupta (1972). Economics of intercropping in young orchards of South-East districts of the Punjab. Punjab Agric. Univ. J. Res. 9(2):354-360.

Kahurananga, J. (1991). Intercropping Ethiopian Trifolium species with wheat. Expl. Agric. 27:385-390.

Kairon, M. S. and A. Singh (1972). Intercropping of cotton with legumes and its residual effect on wheat. Cotton Dev. 2(1):1-5.

Kairon, M. S. and D. S. Nandal (1971). Economics of intercropping of mung and cowpeas in cotton. Allahabad Farmer 45(2):240-241.

Kairon, M. S., A. Singh, and N. D. Arora (1975). Pulses around cotton for enrichment of soil with biological nitrogen intercropping. Indian J. Genet. Plant Breed. 35(2):257-261.

Kaith, D. S. (1980). Intercropping and its after-effect on the yield of Kala Zira Carum bulbocastanum. Indian Cocoa Arecanut Spices J. 4(2):39-41.

Kaitpraneet, W. (1977). Soil improvement of teak plantation by agricultural intercropping. Faculty of Forestry, Kasetsart Univ., Bangkok, Thailand.

Kalmbacher, R. S., D. R. Minnick, and F. G. Martin (1979). Destruction of sod-seeded legume seedlings by the snail (Polygyra cereollus). Agronomy J. 71:365-368.

Kalmbacher, R. S., P. Mislevy, F. G. Martin, et al. (1988). Establishment of aeschynomene in bahiagrass sod. Fla. Agric. Expt. Sta. Circ. S-355.

Kalra, G. S. and B. Gangwar (1980). Economics of intercropping of different legumes with maize at different levels of nitrogen under rainfed conditions. Indian J. Agron. 25(2):181-185.

Kamara, C. S. and I. Haque (1991). Intercropping maize and forage type cowpeas in the Ethiopian highland: I. Growth and dry matter yields. II. Soil moisture soil temperature, solar radiation regimes and water use efficiency. Work, Doc. B14, ILCA, Addis Ababa.

Kamel, M. S. and R. B. Bayoumi (1983). Response of corn and soybean to some intercropping systems and chemical herbicides under Egyptian conditions Zea màys, Glycine max. Ann. Agric. Sci. 19(1):27-44.

Kamel, M. S., M. S. Abdel-Raouf, E. A. Mahmoud, and R. B. Bayoumi (1983). Response of corn and soybean to some intercropping systems and chemical herbicides under Egyptian conditions (Zea mays, Glycine max). Ann. Agric. Sci. Moshtohor 19:27-44.

Kamprath, E. J., W. V. Chandler, and B. A. Krantz (1958). Winter cover crops: Their effects on crop yields and soil properties. North Carolina Agric. Expt. Sta. Bull. 129.

Kang, B. T. and A. S. R. Juo (1984). Review of soil fertility management and cropping systems for wetland rice production in West Africa. In An Overview of Upland Rice Research. Proc., IRRI, Los Banos; Philippines, pp. 493-501.

Kang, B. T., L. Reynolds, and A. N. Atta-Krah (1990). Alley farming. Adv. Agronomy 43:315-359.

Kang, B. T., G. F. Wilson, and T. L. Lawson (1984). Alley cropping, a stable alternative to shifting cultivation. IITA, Ibadan, $22 \mathrm{pp}$.

Kannan, K. and K. P. P. Nambiar (1976). Studies on intercropping coconut garden with annual crops. Coconut Bull. 6(9):1-3.

Kanwar, R. S. (1975). Scope of intercropping in sugarcane in North India. Indian Sugar 25(3):187-189.

Kaplan, K. (1987). ARS sows new crops in Oklahoma. Agric. Res. USDA, The Administration, 35(9):68.

Kaplan, S. L. and M. A. Brinkman (1984). Multiple cropping soybean with oats and barley. Agronomy J. 76:851-854.

Kar, K., R. L. Bhoj, and P. C. Kapoor, (1972). Intercropping in sugarcane with onion for higher production and better economic returns. Indian Sugar 22(4):321-323, 325-326.

Kar, K., R. S. Dixit, and J. S. Saroj (1975). Intercropping with autumn planted sugarcane in the Tarai Tract of Uttar Pradesh. Indian Sugar 25(1):27-30.

Karel, A. K. (1990). Influence of plant populations on insect pests of common beans intercropped with maize. Annul Rep. Bean Improv. Coop., Colorado State Univ., 33:156-157.

Karel, A. K. (1991). Effects of plant populations and intercropping on the population patterns of bean flies on common beans. Environ.Entomol. 20:354-357.

Karel, A. K. (1993). Effects of intercropping with maize on the incidence and damage caused by pod borers of common beans. Environ. Entomology 22:1076-1083. 
Karel, A. K. and B. J. Ndunguru (1982). Intercropping of maize and cowpea: effect of plant populations on insect pests and seed yield. Intercrop. pp. 102-109.

Karikari, S. K. (1984). Plantain in root-crop farming systems. In Tropical Root Crops: Production and Uses in Africa (ed: E.R. Terry. et al.), Proc. $2^{\text {nd }}$ Triennial Symp. Intl. Soc. Trop. Root Crops, Douala, Cameroon, pp. 206-208.

Karnezos, T. P. and A. G. Matches (1992). Modeling lamb weight changes on wheatgrass and wheatgrass-sainfoin mixtures. Agronomy J. 84:5-10.

Kartono, S. dan N. I. (1979). Pengaruh intercrop tomat dan bawang merah terhadap populasi ulat. Bull. Penelitian Hortik. 7(4):3-5.

Kaserer, H. (1911). Beobachtungen uber die Berwurzelung der Kulturpflanzen bei Reinsaat und bei Mischsaat. Zeitschrift fur das Landwirtschaftlichen Versuchswesen in Oesterreich 14:1022-1030.

Kashirad, A. and H. Marschnar (1974). Iron nutrition of sunflower and corn plants in mono and mixed culture. Plant Soil. 41:91-101.

Kass, D. C. (1976). Simultaneous polyculture of tropical food crops with special reference to the management of sandy soils of the Brazilian Amazon. Ph.D. Thesis, Cornell Univ. Ithaca, N. Y.

Kass, D. C. (1977). Models of analysis for polyculture enterprises - cattle raising. Commission des Communautes Europeennes, Bruxelles, 98 pp.

Kass, D. C. (1978). Polyculture cropping systems: review and analysis. N. Y. State College Agric., Cornell Intl. Agric. Bull. 32, 69 pp.

Kass, D. C. (1979). Simultaneous polyculture of tropical food crops with special reference to the management of sandy soils of the Brazilian Amazon. Ann Arbor, Mich. 265 pp.

Kass, D. C. L. (1982). Vegetables suitable for association with subsistence maize and beans in the highlands of Guatemala (Crop yields, intercropping). Proc. Trop. Reg. Amer. Soc. Hort. Sci. Annu. Meet., The Society 25:219-228.

Kassam, A. H. (1973). In search for greater yields with mixed cropping in Northern Nigeria - a report on agronomic work. Inst. Agric. Res., Samaru, Nigeria.

Kassam, A. H. and K. R, Stockinger (1973). Growth and nitrogen uptake of sorghum and millet in mixed cropping. Samara Agric. Newsl. 15(1):28-32.

Kassam, A. H., J. Kowal, M. Stagg and M. N. Harrison (1975). Maize in West Africa, and its potential in Savanna areas. Samara Res. Bull. 250, IAR Samaru, Nigeria.

Kasture, M. N. and A. M. Mungikar (1984). Intercropping short duration crops for leaf protein production. In Progress in Leaf Protein Research: Proc. (ed: N. Singh), Aurangabad, pp. 49-53.

Kasture, M. N. and A. M. Mungikar (1986). Intercropping maize with cowpea and dolichos. Ann. Arid Zone 25:177-179.

Kasture, M. N., H. G. Dakore, and A. M. Mungikar (1987). Intercropping cowpea and dolichos with sorghum for fodder. Geobios 14:12-16.

Katayama, K., O. Ito, R. Matsunaga, et al. (1995). Nitrogen balance and root behavior in four pigeonpeabased intercropping systems. Fertilizer Res. 42:315-319.

Kaul, J. N. and H. S. Sekhon (1974). Intercropping studies with arhar (Cajanus cajun) pigeonpeas. J. Res. Punjab Agric. Univ. 11(2):158-163.

Kaul, J. N., H. S. Sekhon, and B. S. Dahiya (1975). Intercropping studies with pigeonpea Cajanus cajun. Indian J. Genet Plant Breed. 35(2):242-247.

Kaurov, I. A. and T. A. Budkevitch (1973). Kinetics of mineral nutrients in oats and peas in pure and mixed stands during growth and development. Vestsi Akademii Navak BSSR Biyagichnykh Navak (1973) 5. Field Crop Abstracts 27(4). Abst. 1662, 1974.

Kaushik, R. D. (1951). Mixed cropping in the Delhi state. Allahabad Farmer 25:142-149.

Kaushik, S. K. and R. C. Gautam (1987). Effect of nitrogen and phosphorus on the production potential of pearl millet-cow pea or green gram intercropping systems under rainfed conditions. J. Agric. Sci. 108:361-364.

Kavamahanga, F., U. R. Bishnoi, K. Aman (1995). Influence of different N rates and intercropping methods on grain sorghum, common bean, and soya bean yields. Trop. Agric. 72:257-260.

Kawano, H., H. Gonzalez, and M. Lucena (1974). Interspecific competitionn, competition with weeds, and spacing response in rice. Crop Sci. 14:841-845. 
Kawano, K. and M. Thung (1982). Intergenotypic competition and competition with associated crops in cassava. Crop Sci. 22:59-63.

Kawano, K., H. Gonzalez, and M. Lucena (1974). Intraspecific competition, competition with weeds, and spacing response in rice. Crop Sci. 14:841-845.

Kayumbo, H. Y. (1975). Ecological background to pest control in mixed-crop ecosystem in East Africa. Paper, AAAS/Ford Foundation Workshop on Cropping Systems in Africa, Morogoro, Tanzania.

Kayumbo, H. Y. (1976). Pest control in mixed cropping systems. In Intercropping in Semi-Arid Areas (ed: J. H. Monyo, A. D. R. Ker, and M. Campbell). Univ. Dar es Salaam, Morogoro, Tanzania and IDRC, Ottawa, Canada. p. 39.

Keating, B. A. and P. S. Carberry (1993). Resource capture and use in intercropping: Solar radiation. Field Crops Res. 34:273-301.

Keeling, J. W., A. G. Matches, C. P. Brown, and T. P. Karnezos (1996). Comparison of interseeded legumes and small grains for cover crop establishment of cotton. Agronomy J. 88:219-222.

Kellerman, K. and R. C. Wright (1914). Mutual influence of certain crops in relation to nitrogen. Agronomy J. 6:204-210.

Kempanna, C. (1985). Prospects of horizontal growth of oilseeds production in the eighties and nineties. In Oilseed Production: Constraints and Opportunities (ed: H. C. Strivastava et al.). Proc. Symp. Oilseed Production Utilisation-Constraints and Opportunities, pp. 73-87.

Kempton, R. A. (1982). Adjustment for competition between varieties in plant breeding trials. J. Agric. Res. (Camb) 98:599-611.

Kennedy, F. J. S., R. Balaguranathan, A. Christopher, and K. Rajamanickam (1994). Insect pest management in peanut: a cropping system approach. Trop. Agric. 71:116-118.

Kerkam, R. K. (1941). A note on wheat cultivation in Uganda. E. Afr. Agric. For: J. 6:167-168.

Kerr, H. D., A. M. Bagegni, and D. A. Sleper (1987). Interim legume crops and herbicides for replacing endophytic tall fescue with new cultivars. In The Role of Legumes in Conservation Tillage Systems (ed: J.F. Power). Ankeny, Iowa, pp. 124-125.

Keswani, C. L, T. H. M. Kibani and M. A. Chowdhury (1977). Effect of intercropping on rhizosphere population in maize (Zea mays L. ) and soybean (Glycine max Merill.). Agric. Envir.3:363-368.

Keswani, C. L. and R. A. D. Mreta (1982). Effect of intercropping on the severity of powdery mildew on green-gram Vigna radiata, sorghum, millet, Erysiphae polygoni, Tanzania. Intercrop. pp. 110-114.

Khader, K. B. A. (1982). Inter and mixed cropping in areca gardens. Indian Farm. 32(9):21-23.

Khader, K. B. A. and K. J. Anthony (1968). Intercropping: a paying proposition for areca growers. Indian Farmer 18:14-15.

Khalifa, M. A. and C. O. Qualset (1974). Intergenotypic competition between tall and dwarf wheats. I. In mechanical mixtures. Crop Sci. 14:795-799.

Khalilian, A., C. E. Hood, J. H. Palmer, et al. (1990). Conservation tillage interseeding soybeans into standing wheat. In Consevation Tillage For the 1990's. Proc. Southern Region Conserv. Tillage Conf., North Carolina State Univ. Spec. Bull. 90-1, pp. 72-76.

Khalilian, A., C. E. Hood, J. H. Palmer, et al. (1991). Soil compaction and crop response to wheat/soybean interseeding. Trans. ASAE 34:2299-2303.

Khalilian, A., T. H. Garner, C. E. Hood, and M. J. Sullivan (1991). A progress report on cotton production systems for soil and energy conservation. Proc Beltwide Cotton Conf. 1:449-452.

Khehra, A. S. and R. K. Sharma (1979). Studies on intercropping of maize (Zea mays L.) with black gram (Phaseolus mungo Roxb.) . Indian J. Agric. Res. 13:23-26.

Khekhar, K. S. and S. S. Singh (1979). Economic feasibility of intercropping of potato with wheat, barley, maize, mustard and sunflower in relation to row direction. Allahabad Farmer 50(4):373.

Kidd, T. J. and T. Taogaga (1984). Survival and herbage yield of six nitrogen-fixing trees intercropped with taro in Western Samoa. Nitrogen Fixing Tree Res. Rep. 2:22-23.

Kilby, M. W. (1979). Orchard floor management for young pecan trees in the El Paso Valley. Proc Annu Conf. Texas Pecan Grow. Assoc., The Association 57:40-41.

Kilby, M. W. (1979). Orchard floor management for young pecan trees in the E1 Paso Valley. Pecan South. 6(1):26-27.

Kilcher, M. R. and D. H. Heinrichs (1966). Persistence of alfalfas in mixture with grasses in a semiarid region. Can. J. Plant Sci. 46:163-167. 
Kilcher, M. R. and D. H. Heinrichs (1971). Stand patterns for alfalfa-grass hay production in a dry climate. Can. J. Plant Sci. 51:317-322.

Kim, J. H. and D. M. Park (1979). Res. Rep. Off. Rural Dev. Hortic. Agric. Eng. Korea (Repub.) Nongeh' on Jin Heung Chung. 21:29-36.

King, F. H. (1911). Farmers of Forty Centuries. Harcourt, Brace \& Co., New York, 441 pp.

King, J. (1971). Competition between established amd newly sown grass species. J. Br. Grassl. Soc. 26:221-229.

Kinney, E. J. and G. Roberts (1921). Soybeans. Kentucky Agric. Expt. Sta. Bull. 232. 57 pp.

Kirby, E. M. (1986). Soil moisture depletion and wheat yield response from annual legumes in the Pacific Northwest. M. S. Thesis, Washington State Univ., Pullman, WA.

Kireev, V. M. (1981). Catch cropping of forage crops. Moskva, Kolos, 84, 1 p.

Kireev, V. M. (1981). Promezhutochnye posevy kormovykh kul'tur. Moskva: Kolos 84. 1 p.

Kirkland, K. J. and J. H. Hunter (1991). Competiveness of Canada praire spring wheats with wild oat (Avena fatua L.). Can. J. Plant Sci. 71:1089-1092.

Kirkpatrick, B. L., L. M. Wax, and E. W. Stoller (1983). Competition of jimsonweed with soybean. Agronomy J. 75:833-836.

Kitamura, Y. and S. Nishimura (1979). Studies on mixed cultivation of tropical legumes and grasses. VIII. Growth and N fixation in the cowpea/corn intercropping as affected by plant competition for light and soil nutrients. J. Japan Grassl. Sci. 25:35-42.

Klages, K. H. W. (1936). Changes in proportion of components of seeded and harvested cereal mixtures. Agronomy. J. 28:935-940.

Klaij, M. C., C. Renard, and K. C. Reddy (1994). Low input technology options for millet-based cropping systems in the Sahel. Expl. Agric. 30:77-82.

Klebesadel, L. J. and D. Smith (1959). Light and moisture beneath several companion crops as related to establishment of alfalfa and red clover. Bot. Gaz. 121:39-46.

Klebesadel, L. J. and D. Smith (1960). Effects of harvesting an oat companion crop at four stages of maturity on the yield of oats, on light near the soil surface, on soil moisture, and on the establishment of alfalfa. Agronomy J. 52:627-630.

Kline, C. K., D. A. G. Green, R. L. Donahue, and B. A. Stout (1969). Agricultural mechanization in equatorial Africa. Inst. Intl. Agric. Res. Rep. No. 6, Michigan State Univ., East Lansing.

Klocke, N. L., J. T. Nichols, P. H. Grabouski, and R. Todd (1989). Intercropping corn in perennial coolseason grass on irrigated sandy soil. J. Prod. Agric. 2:42-46.

Kloen, H. and M. A. Altieri (1990). Effect of mustard (Brassica hirta) as a non-crop plant on competition and insect pests in broccoli (Brassica oleracea). Crop Protection 9:90-96.

Kluson, R. A. (1995). Intercropping allelopathic crops with nitrogen-fixing legume crops: a tripartite symbiosis perspective. In Allelopathy : Organisms, Processes, and Applications. Amer. Chem. Soc., Washington, D.C., pp. 193-210.

Knake, E. L. (1984). Control of established alfalfa and associated quackgrass for no-till planting of corn. Res. Rep. North Central Weed Control Conf. 41:119.

Knake, E. L. and F. W. Slife (1965). Giant foxtail seeded at various times in corn and soybean. Weeds 13:331-334.

Knauft, D. A. (1983). Genotype $\times$ cropping system interactions of peanuts grown as a sole crop and in association with maize. Trop. Agric. (Trinidad) 61:12-16.

Knight, W. E. (1970). Productivity of crimson and arrowleaf clover grown in a coastal bermudagrass sod. Agronomy J. 62:773-775.

Knight, W. E. (1971). Influence of spring mowing on reseeding and productivity of selected annual clovers in a grass sod. Agronomy J. 63:418-420.

Kobat, R. B. S., I. Ibrahim, and T. E. Lee (1986). RRMM integrated agricultural development strategy for rubber smallholdings. Intl. Rubber Conf. Proc., Kuala Lumpur, Malaysia, 3:747-761.

Koli, S. E. (1975). Pure cropping and mixed cropping of maize and groundnut in Ghana. Ghana J. Agric. Sci. 8:23-30. 
Kolo, M. G. M. (1995). Effects of intercropping melon (Citrullus lanatus) with yam (Dioscorea rotundata) under different staking methods on weed control and crop production. Trop. Agric. 72:102-104.

Kong, B. T. and L. Reynolds (1989). Alley farming in the humid and subhumid tropics. Proc. Intl. Workshop, Ibadan, Nigeria, $251 \mathrm{pp}$.

Korac, M., S. Cerovic, and B. Golosin (1993). Results of walnut/apricot interplanting. Acta Hort. 311:266-272.

Koregave, B. A. (1964). Effect of mixed cropping on growth and yield of suran (Elephant Yam) Amorphophallus campanulatus Blume. Indian J. Agron. 9: 255-260.

Kortenhorst, L. F. (1986). The existing farming system: a neglected criterion for irrigation project design? Annu. Rep. Int. Inst Land Reclam. Improv., The Institute, Wageningen, pp. 8-24.

Koscelny, J. A., T. F. Peeper, J. B. Solie, and S. G. Solomon (1990). Effect of wheat (Triticum aestivum) row spacing, seeding rate, and cultivar on yield loss from cheat (Bromus secalinus). Weed Technol. 4:487-492.

Kouame, C. N., J. M. Powell, C. A. Renard, and K. H. Quesenberry (1993). Plant yields and fodder quality related characteristics of millet-style intercropping systems in the Sahel 85:601-605.

Kouame, C. N., S. Hoefs, M. Powell et al. (1992). Intercrop Stylosanthes effect on pearl millet yields and animal performance in the Sahel. Proc. Workshop Complementarity Feed Resources Animal Prod. Africa, Addis Ababa, Ethiopia, pp. 137-146.

Krantz, B. A. (1974). Cropping patterns for increasing and stabilizing agricultural production in the semiarid tropics. Proc. Intl. Workshop on Farming Systems. ICRISAT, Hyderabad, India. pp. 217248.

Krantz, B. A., et al. (1975). Cropping patterns for increasing and stabilizing agricultural production in the semi-arid tropics. Proc. Intl. Workshop on Farming Systems. ICRISAT, Hyderabad, India, pp. 217-248.

Krantz, B. A., S. M. Virmani, Sardar Singh, and M. R. Rao (1976). Intercropping for increased and more stable agricultural production in the semi-arid tropics. In Intercropping in Semi-Arid Areas (ed: J. H. Monyo, A. D. R. Ker and M. Campbell). Univ. Dar es Salaam, Morogoro, Tanzania and IDRC, Ottawa, Canada. p. 15.

Krause, M. A., R. R. Deuson, T. G. Baker, et al. (1990). Risk sharing versus low-cost credit systems for international development. Amer. J. Agric. Econ. 72:911-922.

Kretzschman, A. G. (1978). Short-lived perennial rye grass help to increase the success of farming intercropping. Dlg Mitt Dtsch Landwirtsch Ges. 93(13): 778-779.

Kreuger, C. P. and J. M. Scholl (1970). Performance of bromegrass, orchardgrass and reed canarygrass grown at five nitrogen levels and with alfalfa. Wisconsin Agric. Expt. Sta. Res. Rep. 69.

Kriakou, D. T. and A. C. Fasoulas (1985). Effects of competition and selection pressure on yield response in winter rye (Secale cereale L.). Euphytica 34:883-895.

Krishnamurthy, Ch., S. L. Choudhury and D. T. Anderson (1978). Intercrop systems with particular reference to pigeonpea/sorghum present practices and new recommendations. Paper, Natl. Seminar on Intercropping of Pulse Crops in India, Indian Agric. Res. Inst., New Delhi.

Krishnamurthy, R. (1972). Studies on mixed cropping of groundnut and hybrid sorghum. Indian J. Agron. 17(1):27-29.

Krishnaraj, P. and V. K. Sasidhar (1979). Economics of intercropping in guineagrass (Panicum maximum L.). Agric. Res. J. Kerala 17 (2):267-269.

Krishnasamy, M. and S. P. Palaniappan (1979). Complimentary and competitive effect of associated crops in a groundnut based intercropping system. Madras Agric. J. Coimbatore 66(11):757-759.

Kroontje, W. and W. R. Kehr (1956). Legume top and root yields in the year of seeding and subsequent barley yields. Agronomy J. 48:127-131.

Kropff, M. J. (1988). Modelling the effects of weeds on crop production. Weed Res. 28:465-471.

Kropff, M. J., F. J. H. Vossen, C. J. T. Spitters, and W. De Groot (1984). Competition between a maize crop and a natural population of Echinochloa crus-galle (L.). Neth. J. Agric. Sci. 32:324-327.

Krueger, C. R. and J. M. Scholl (1970). Performance of bromegrass, orchardgrass and reed canarygrass grown at five nitrogen levels and with alfalfa. Wisconsin Agric. Expt. Sta. Res. Rep. 69:1-24. 
Krutman, S. (1968). Cultura concorciada cana $\times$ feijoeiro. Premeiros resultados. Pesquisa Agropecuaria Brasileira 3:127-134.

Kuan, C. Y. and T. G. Kok (1982). Pre-treatment of legume cover crop seeds Calopogonium caeruleum, Calopogonium mucunoides, Centrosema pubescens, Pueraria phaseoloides, intercropping with Hevea. Planters Bull. Kuala Lumpur, No. 170. pp. 10-13.

Kuan, C. Y., C. T. Voon, and A. Rashid-bin-Shariff (1982). Testing of legume cover crop seeds (Calopogonium caeruleum, Calopogonium mucunoides, Centrosema pubescens, Mucuna cochinchinensis and Pueraria phaseoloides, intercropping with Hevea, quality and viability, Malaysia). Kuala Lumpur, Planters Bull. Issue 170, pp. 3-9.

Kukal, S. S., K. L. Khera, and M. S. Hadda (1993). Soil erosion management on arable lands of submontane Punjab India: a review. Arid Soil Res. Rehabilitation 7:369-375.

Kulkarni, K. R. and R. K. Pandey (1988). Annual legumes for food and as green manure in a rice-based cropping system. In Sustainable Agriculture-Green Manure in Rice Farming. Intl. Rice Res. Inst., Los Banos, Philippines, pp. 289-299.

Kumar, C. R. M., and N. Hrishi (1979). Intercropping systems with cassava in Kerala State, India. Ottawa, International Development Research Centre, pp. 31-34.

Kunasekaran, V. and U. S. Sree Ramulu (1980). Intercropping in rainfed sorghum legumes, India. Tamil Nadu Agric. Univ. Madras Agric. J. Coimbatore 67(12):816-818.

Kundu, A. L. and B. N. Chatterjee, (1982). Growth analysis of Turmeric curcuma-longa as a sole crop in mixtures with other crops. Indian J. Agric. Sci. 52(9):584-589.

Kunelius, H. T. and P. Narasimhalu (1983). Yield and quality of Italian and Westerwolds ryegrasses, red clover, alfalfa, birdsfoot trefoil, and persian clover grown in monocultures and ryegrass-legume mixtures. Can J. Plant Sci. 63:437-442.

Kung, P. (1969). Multiple cropping in Taiwan. World Crops 21:128-130.

Kung, P. (1975). Farm crops of China. 3. Multiple cropping. World Crops 27:228-236.

Kupkanchanakul, T., D. W. Puckridge, K. Petchrit, et al. 1986. Production from deepwater rice and early maturing rice intercrops with different row combinations. Field Crops Res. 14:53-62.

Kurle, J. E. and F. L. Pfleger (1994). Arbuscular mycorrhizal fungus spore populations respond to conversions between low-input and conventional management practices in a corn-soybean rotation. Agronomy J. 86:467-475.

Kurtz, L. T., L. V. Boone, T. R. Peck, and R. G. Hoeft (1984). Crop rotations for efficient nitrogen use. In Nitrogen in Crop Production (ed: R. D. Hauck). ASA, CSSA, and SSSA, Madison, WI, pp. 295306.

Kurtz, T., S. W. Melstead, R. H. Bray, and H. L. Breland (1952). Further trials with intercropping of corn in established soils. Soil Sci. Proc. 16:282-285.

Kurtz, T., S. W. Melsted, and R. H. Bray (1952). The importance of nitrogen and water reducing competition between intercrops and corn. Agronomy J. 44:13-17.

Kushwaha, B. L. (1985). Effect of fertilizers on the yields of mustard and lentil in intercropping systems. Indian J. Agron. 30:154-157.

Kushwaha, B. L. and R. De (1987). Studies of resource use and yield of mustard and chickpea grown in intercropping systems. J. Agric. Sci. 108:487-495.

Labandera, C., S. K. A. Danso, D. Pastorini, et al. (1988). Nitrogen fixation in a white clover-fescue pasture using three methods of nitrogen-15 application and residual nitrogen-15 uptake. Agronomy J. 80:265-268.

Ladd, J. N., A. Amato, R. B. Jackson, and J. H. A. Butler (1983). Utilization by wheat crops of N from legume residue decomposing in soils in the field. Soil Biol. Biochem. 15:231.

Ladd, J. N., J. M. Oades, amd M. Amato (1981). Distribution and recovery of nitrogen from legume residues decomposing in soils sown to winter wheat in the field. Soil Biol. Biochem. 13:251-256.

Lagemann, J. (1977). Traditional African Farming Systems in Eastern Nigeria. Afrika-Studien No. 98. Weltform Verlag, Munich, $269 \mathrm{pp}$.

Lahiri, A. K. (1972). Intercropping trials with turmeric in North Bengal. Indian For. 98(2):109-115.

Laidlaw, A. S. and J. M. McBratney (1980). The effect of companion perennial ryegrass cultivars on red clover productivity when timing of the first cut is varied. Grass Forage Sci. 35:257-265. 
Lakhani, D. A. )1976). A crop physiological study of mixtures of sunflowers and fodder radish. Ph. D. Thesis, Univ. Reading, UK.

Lal, D. N. (1979). A note on an index of utility of mixed cropping and allocation of such areas under separate crops. Indian J. Agric. Stat. XXXI(3): 59-64.

Lal, L. (1991). Effect of inter-cropping on the incidence of potato tuber moth, Phthorimaea operculella (Zeller). Agric. Ecosyst. Environ. 36:185-190.

Lal, R. (1973). Soil erosion and shifting cultivation. FAO/SIDA Regional Seminar on Shifting Cultivation and Soil Conservation in Africa, Ibadan.

Lall, M. (1977). Weed management can raise yields of sugarcane. Indian Farming 26(12):25-33, 37.

Lambert, J. D. H., J. T. Arnason, A. Serratos, et al. (1987). Role of intercropped red clover in inhibiting European corn borer (Lepidoptera: Pyralidae) damage to corn in eastern Ontario. J. Econ. Entomol. 80:1192-1196.

Lamberts, M. (1985). Three faces of intercropping in Dade County, Florida. Proc. Ann. Meet. Fla. State Hort. Soc. 97:366-371.

Lamberts, M. L. (1980). Intercropping with potatoes. M. S. Thesis, Cornell Univ.

Lamberts, M. L. (1983). Relay intercropping peas and sweet corn - A study of experimentation on intercropping. Ph.D. Thesis, Cornell Univ.

Lamont, W. J., D. L. Hensley, S. Wiest, and R. E. Gaussoin (1993). Relay-intercropping muskmelons with Scotch pine Christmas trees using plastic mulch and drip irrigation. Hort. Sci. 28:177-178.

Lamp, W. O. (1991). Reduced Empoasca fabae (Homoptera: Cicadellidae) density in oat-alfalfa intercrop systems. Environ. Entomol. 20:118-126.

Langdale, G. W., W. L. Hargrove, and J. Giddens (1984). Residue management in double-crop conservation tillage systems. Agronomy J. 76:689-694.

Lanini, W. T., S. B. Orloff, R. N. Vargas, et al. (1991). Oat companion crop seeding rate effect on alfalfa establishment, yield, and weed control. Agronomy J. 83:330-333.

Laosuwan, P., P. Sripana, P. Sirisongkram, and A. Tongsomsri (1987). Potential of food legumes as intercrops with young rubber. Australian Centre Intl. Agric. Res. (ACIAR), p. 240.

Larios, J., J. Arze, and R. Arias (1982). The animal component in maize-sorghum farming systems in Central America. Case Studies for a Workshop: Res. Crop-Animal Syst., Caribbean Agric. Res. Dev. Inst., pp. 250-277.

Larkcom, J. (1978). Productivity in the vegetable garden intercropping yields. Garden 103(4):135-140.

Laskey, B. C. and R. C. Wakefield (1978). Competitive effects of several grass species and weeds on the establishment of birdsfoot trefoil. Agronomy J. 70:146-148.

Latheef, M. A., J. H. Ortiz, and A. Q. Sheikh (1984). Influence of intercropping on Phylloterta cruciferae (Coleoptera:Chrysomelidae) populations on collard plants. J. Econ. Entomol. 77:1180-1184.

Laurent, F. and B. Mary (1992). Management of nitrogen in farming systems and the prevention of nitrate leaching. From research conclusions to practical advice: the situation in France. Aspects Applied Biol. 30:45-61.

Lazarus, W. F., L. D. Hoffman, and E. J. Partheimer (1980). Economic comparisons of selected cropping systems on Pennsylvania cash crop and dairy farms with highly productive land. Pennsylvania Agric. Expt. Sta. Bull. 828.

Leach, J. R., R. Shepherd, and P. D. Turner (1971). Underplanting coconuts with cocoa in West Malaysia. I. Planting. Cocoa Growers' Bull. 17:5-10.

Leasure, J. K. (1949). Determining the species composition of swards. Agronomy J. 41:204-206.

Leciezio, M. F.A., J. D. Lea, and P. K. Moberly (1985). Intercropping of beans (Phaseolus vulgaris L.) and sugar-cane: the effect of inter-specific competition on the growth of plant cane. S. Afr. J. Plant Soil 2:59-66.

Leclezio, M. F. A., J. D. Lea, and P. K. Moberly (1984). Intercropping of beans (Phaseolus vulgaris L.) and sugarcane (Saccharum spp): the effect of inter-specific competition during the early growth stage of plant cane. South African Society of Crop Production, vol. 13, pp. 15.

Ledesma, F. I., and Villarico, E. S. ( 1977) . Intercropping sugarcane with mungbean, peanut, soybean, rice and corn in Philippines. Victorias Agric. Res. Rep. 14. 33 pp.

Ledgard, S. F., J. R. Freney, and J. R. Simpson (1985). Assessing nitrogen transfer from legumes to associated grasses. Soil Biol. Biochem. 17:575-577. 
Ledgard, S. F., J. R. Simpson, J. R. Freney, and F. J. Bergersen (1985). Field evaluation of ${ }^{15} \mathrm{~N}$ techniques for estimating nitrogen fixation in evaluation of legume-grass associations. Aust. J. Agric. Res. 36:247-258.

Lee, C. K. J. (1986). The use of trees in Chinese land husbandry. Commonw. For. Rev. 65:23-31.

Lee, E. W., J. O. Pae, K. H. Kang, and Y. K. Kang (1975). Studies on the mixed cropping possibility of sunflowers. I. Productive responses of mixed cropping of soybean (Glycine max M.) and sunflower (Helianthus annula L.). II. Productive responses of mixed cropping of sweetpotato (Ipomoea batatas P.) and sunflower. Soul Taehakkyo Nonmunjip, B Shang Nong Ge. 25:1-26.

Lee, H. C., M. P. Berry, V. C. de Toledo, et al. (1994). Non-chemical weed management in major UK arable crops. Aspects Applied Biol. 40:317-324.

Lee, H. S. (1985). Effects of mixed intercropping on growth and yield of peanut and sesame. Nongsa Sihom Yon'gu Pogo Nongki Nongka Nongkyong Res. Rep. Rural Dev. Admin. 27:185-190.

Lee, S. A. (1972). Agro-economic studies on intercropping in pineapple. Malay Pineapple Ind. Board. Malays Pineapple. 2:23-32.

Lefrancois, M. P. and T. W. Scott (1988). Phosphorus response of forage legumes intercropped in corn. Appl. Agric. Res. 3:105-109.

Leihner, D. E. ( 1979) . Agronomic implications of cassava-legume intercropping systems, Colombia. Ottawa, Intl. Dev. Res. Centre, pp. 103-112.

Leihner, D. E. (1983). Management and evaluation of intercropping systems with cassava. CIAT, Cali, Columbia.

Leihner, D. E., M. Ruppenthal, T. H. Hilger, and F. J. A. Castillo (1996). Soil conservation effectiveness and crop productivity of forage legume intercropping, contour grass barriers and contour ridging in Cassava on Andean hillsides. Expl. Agric. 32:327-338.

Lepiz, I. R. ( 1971 ) . Asociacion de cultivos maiz-frijol. Agricultura tecnia en Mexico. 3(3):98-101.

Lepiz, I. R. (1978). La asociacion maiz-frijol y el aprovechamiento de la luz solar. Chapingo, Mexico: Secretaria de Agricultura y Recursos Hidraulicos, Colegio de Postgraduados, Rams de Genetica. $304 \mathrm{pp}$.

Letourneau, D. K. (1987). The enemies hypothesis: tritrophic interactions and vegetational diversity in tropical agroecosystems. Ecology Publ. Ecol. Soc. Amer. 68:1616-1622.

Letourneau, D. K. (1990). Mechanisms of predator accumulation in a mixed crop system. Ecol. Entomol. 15:63-69.

Letourneau, D. K. (1990). Two examples of natural enemy augmentation: a consequence of crop diversification. Ecol. Stud. Anal. Synth. 78:11-29.

Letourneau, D. K. (1995). Associational susceptibility: effects of cropping pattern and fertilizer on Malawian bean fly levels. Ecol. Applications 5:823-829.

Leung, W. (1973). Food Composition Table for Use in East Asia. Washington, D.C.: U.S. Govt. Printing Office.

Levin, A., D. B. Beegle, and R. H. Fox (1987). Effect of tillage on residue nitrogen availability from alfalfa to succeeding corn crops. Agronomy J. 79:34-38.

Levin, F. I., V. S. Divachenko, and S. M. Belozerov (1985). Increase in productivity of sod-podzol soils upon introduction of intercropping. Mosc. Univ. Soil Sci. Bull. 40:34-39.

Lewandowski, S. (1987). Diohe'ko, The Three Sisters in Seneca life: implications for a native agriculture in the Finger Lakes region of New York State. Agric. Hum. Val. 4:76-93.

Lewis, W. M. (1972). No tillage production systems for double-cropping, for cotton and other crops. Proc. No Tillage System Symp., Columbus, Ohio, pp. 146-152.

Lewis, W. M. and J. A. Phillips (1976). Double cropping in the eastern United States. Spec. Bull. 27, ASA, CSSA, and SSSA, Madison, WI, pp. 41-50.

Liboon, S. P. and R. R. Harwood ( 1975) . Nitrogen response in corn/soybean intercropping. Paper, $6^{\text {th }}$ Annual Scientific Meeting Crop Sci. Soc. Philippines, Bacolod City.

Liebman, M. (1988). Ecologocal supprression of weeds in intercropping systems: A review. In Weed Management in Agroecosystems (ed: M. A. Alteiri and M. Liebman). CRC Press, Boca Raton, FL, pp. 197-211.

Liebman, M. (1989). Effects of nitrogen fertilizer, irrigation, and crop genotype on canopy relations and yields of an intercrop/weed mixture. Field Crops Res. 22:83-100. 
Liebman, M. and E. A. Dyck (1993). Crop rotation and intercropping strategies for weed management. Ecol. Appl. 3:92-122.

Lightfoot, C. W. F. and R. S. Tayler (1987). Intercropping sorghum with cowpea in dryland farming systems in Botswana. I. Field experiments and relative advantages of intercropping. Expl. Agric. 23:425-434.

Lightfoot, C. W. F., K. B. G. Dear, and R. Mead (1987). Intercropping sorghum with cowpea in dryland farming systems in Botswana. II. Comparative stability of alternative cropping systems. Expl. Agric. 23:435-442.

Lima, R. N. de and N. E. de M. Beltrao (1983). Effects of fertilizer application in perennial cotton grown in association with maize and beans, and subjected to different cultivation methods (Intercropping, tillage, yields, Paraiba State, Brazil). Bol. Pesqui.Cent. Nac. Pesqui. Algodao, EMBRAPA, Issue 3, pp. 49-59.

Lin, C. C. and J. H. Torrie (1971). Alternate row multistrain culture in soybeans. Crop Sci. 11:331-334.

Lin, C. S. and J. H. Torrie (1968). Effect of plant spacing within a row on the competitive ability of soybean genotypes. Crop Sci. 8:585-588.

Lingegouda, B. K., S. M. Shanthaveeraigh, S. Indamar, and K. Rrishnamarthy (1972). Studies on mixed cropping of groundnut and hybrid sorghum. Indian J. Agron. 47:21-29.

Lipman, J. G. (1912). The associative growth of legumes and non-legumes. New Jersey Agric. Expt. Sta. Bull. 253, 48 pp.

Lira, M. de A. (1978). Consorciacao de sorgo, milho, algodao e feijao macassar. Trabalho, XII Reuniao Brasileira de Milho e Sorgo. Goiania.

Litav, M. and D. Isti (1974). Root competition between two strains of Spinacia oleracea I. J. Appl. Ecol. 11:1007-1016.

Litsinger, J. A. and K. Moody (1976). Integrated pest management in multiple cropping systems. In Multiple Cropping (ed: R. I. Papendick et al.), ASA, CSSA, and SSSA, Madison, WI, pp. 293-316.

Litsinger, J. A., V. Hasse, A. T. Barrion, and H. Schmutterer (1991). Response of Ostrinia furnacalis (Guenee) (Lepidoptera: Pyralidae) to intercropping. Environ. Entomol. 20:988-1004.

Liyanage, M. de, S., K. G. Tejwani, and P. K. R. Nair (1984). Intercropping under coconuts in Sri Lanka. Agroforestry Syst. 2:215-228.

Lloveras, V. J. (1987). Traditional cropping systems in northwestern Spain (Galicia). Agric. Syst. 23:259275.

Lloyd, M. P. J. (1989). A family of agronomic production functions with economies of scope. Aust. J. Agric. Econ. 33:108-122.

Lodha, S. and M. Singh (1984). Quantitative determination of Macrophomina phaseolina (Tassi) Goid. in grass-legume intercropping systems. Ann. Arid Zone 23:259-261.

Lohnis, F. (1926). Nitrogen availability of green manures. Soil Sci. 22:253-290.

Lohry, R. D. (1987). Nitrogen uptake, yield, and fertilizer use efficiency in a sorghum-soybean rotation. M. S. Thesis, Univ. Nebraska, Lincoln.

Lolas, P. C. and H. D. Coble (1982). Non-competitive effects of johnsongrass (Sorghum halepense) on soybeans (Glycine max). Weed Sci. 30:56-79.

Lolas, P. C. and H. D. Coble (1982). Noncompetitive effects of johnsongrass (Sorghum halepense) on soybean (Glycine max.). Weed Sci. 30:589-593.

Lomte, M. H. and R. S. Dabhade (1982). Response of redgram genotypes to population in intercropping pigeonpea, India. Sorghum Improvement Conf. North America, Sorghum Newsl. 5:50-51.

Loomis, R. S. and D. J. Connor (1992). Crop Ecology: Productivity and Management of Agricultural Systems. Cambridge Univ. Press, New York.

Lopes, L. H. O., V. Naspolini Filho, and M. A. de Queiroz (1976). Avaliacao preliminar do consorcio milho $\mathrm{x}$ feijao macassar (Vigna unguiculata L.). Walp em area de baixa precipitacao. Petrolina, EMBRAPA/CPATSA, $12 \mathrm{pp}$.

Lopez-Bellido, L. (1992). Mediterranean cropping systems. In Field Crop Ecosystems: Ecosystems of the World 18 (ed: C. J. Pearson). Elsevier, Amsterdam, pp. 311-356.

Lopez-Bellido, L., M. Fuentes, J. E. Castillo, et al. (1996). Long-term tillage, crop rotation, and nitrogen fertilizer effects on wheat yield under rainfed Mediterranean conditions. Agronomy J. 88:783-791. 
Lorenz, R. J., and G. A. Rogler (1973). Growth rate of mixed prairie in response to nitrogen and phosphorous fertilization. J. Range Management 26:365-368.

Lory, J. A., G. W. Randall, and M. P. Russelle (1995). Crop sequence effects and response of corn and soil inorganic nitrogen to fertilizer and manure nitrogen. Agronomy J. 87:876-883.

Loshakov, V. G. (1980). Catch crops in nonchernozem crop rotations. Moskva, Rossel'khozizdat, 131 pp.

Loshakov, V. G. (1980). Promezhutochnye kul 'tury $v$ sevooborotakh nechernozemnoizony. Rossel'khozizdat, Moskova, $131 \mathrm{pp}$.

Lowenberg, D. J., M. Krause, R. Deuson, and K. C. Reddy (1991). Simulation of yield distributions in millet-cowpea intercropping. Agric. Syst. 36:471-487.

Lu, B. Z. (1982). Chiang Su Nung Yeh Hseuh Jiangsu Nongye Kexue Chiang Su Agric Sci. Nan-ching, China, Chiang-su nung yeh k'o hsueh yaun, No. 2. pp. 28-32.

Ludwig, H. D. (1968). Permanent cropping on Ukara: The impact of land shortage on husbandry practices. In Smallholder Farming and Smallholder Development in Tanzania (ed.: H. Ruthenberg). IFO Inst. Economic Studies, African Studies No. 24, Munich, pp. 87-135

Luedders, V. D. (1979). Effect of maturity on competitive ability in soybean. Euphytica 28:509-513.

Lugo-Lopez, M. A., B. G. Capo, F. Arostegui, and A. Riollano (1953). Intercropping sugarcane with food crops. J. Agric. Univ. Puerto Rico 37:171-182.

Luna-Orea, P. and M. G. Wagger (1996). Management of legume cover crops in the Bolivian Amazon to sustain crop yields and soil productivity. Agonomy J. 88:765-776.

Luna-Orea, P., M. G. Wagger, and M. L. Gumpertz (1996). Decomposition and nitrogen release dynamics of two tropical legume cover crops. Agronomy J. 88:758-764.

Lund, M. G., P. R. Carter, and E. S. Oplinger (1993). Tillage and crop rotation affect corn, soybean, and winter wheat yields. J. Prod. Agric. 6:207-213.

Lutwick, L. E. and A. D. Smith (1977). Yield and composition of alfalfa and crested wheatgrass grown singly and in mixture as affected by $\mathrm{N}$ and $\mathrm{P}$ fertilizer. Can. J. Plant Sci. 57:1077-1083.

Lutz, J. F. (1954). Influence of cover crops on certain physical properties of soils. In Winter Cover Crops in North Carolina. N. Carolina State Univ. Res. Rep. 12, pp. 6-9.

Lynd, J. Q., E. A. Hanlon, Jr., and G. V. Odell, Jr. (1984). Soil fertility and defoliation effects with arrowleaf clover and nitrogen fertilizer equivalence of crimson-arrowleaf clover combinations. Agronomy J. 76:13-16.

Lyon, T. L. (1925). The effect of some legumes on the yields of succeeding crops. Cornell Univ. Agric. Expt. Sta. Bull. 447. 20 pp.

Lyon, T. L. and J. A. Bizzell (1911). A heretofore unnoted benefit from the growth of legumes. Cornell Univ. Agric. Expt. Sta. Bull. 294, 20 pp.

Mabagala, R. B. and A. W. Saettler (1992). Pseudomonas syringae pv. phaseolicola populations and halo blight severity in beans grown alone or intercropping with maize in northern Tanzania. Plant Dis. 76:687-692.

Machet, J. M. and B. Mary (1989). Impact of agricultural practices on the residual nitrogen in soil and nitrate losses. In Management Systems To Reduce Impact of Nitrates (ed: J. C. Germon and S. Dupain). Elsevier Applied Sci., New York, pp. 126-146.

MacLauchlan, R. S. and A. L. Hafenrichter (1961). Alternate-row grass-legume seedings. J. Soil Water Conserv.16:61-64.

MacLean, J. T. (1986). Double cropping and interplanting, 1984-March 1986. The Library Issue 86-78, $23 \mathrm{pp}$.

Maclean, J. T. (1987). Double cropping and interplanting 1984-March 1987. USDA, The Library Issue 87-66, 24 pages.

Maclean, J. T. (1988). Agroforestry: 1979-March 1988. USDA, The Library Issue 88-70, 32 pages.

Maclean, J. T. (1989). Double cropping and interplanting June 1986-August 1988. USDA, The Library, Issue $89-14,28$ pages.

MacLean, J. T. (1990). Agroforestry systems, January 1986-November 1989. USDA, The Library, 90-27, $33 \mathrm{pp}$.

Madany, M. H. (1992). Intercropping fodder trees: a case study from Somalia. Rangelands 14(4):208-213. 
Madhavan, M., V. S. Shanmugasundaram, and S. Palaniappan (1986). Effects of population on physiological growth parameters of pigeonpea genotypes in sole and intercropped stand with sorghum CO 22. J. Agron. Crop Sci. Z. Acker Pflanzenbau 157:43-51.

Madhok, R. M. (1940). Associations of legumes and nonlegumes. Soil Sci. 49:419-429.

Maghembe, J. A. and J. F. Redhead (1982). Agroforestry: Preliminary results of intercropping acadia, eucalyptus, and leucaena with maize and beans Zea mays, Phaseolus, Tanzania. Intercrop. Ottawa. pp. 43-49.

Maghembe, J. A., A. R. S. Kaoneka, and L. L. L. Lulandala (1986). Intercropping, weeding and spacing effects on growth and nutrient content in Leucaena leucocephala at Morogoro, Tanzania. For. Ecol. Mgt. 16:269-279.

Mahadevan, N. R. and S. Chelliah (1986). Influence of intercropping legumes with sorghum on the infestation of the stem borer, Chilo partellus (Swinhoe) in Tamil Nadu, India. Trop. Pest Mgt. 32:162-163, 191, 195.

Mahapatra, I. C., D. M. Leeuwrik, and K. N. Singh (1973). Green revolution through multiple cropping in India. Agric. Mech. Asia, 4:37-42.

Mahler, R. L. and D. L. Auld (1989). Evaluation of green manure potential of Austrian winter peas in northern Idaho. Agronomy J. 81:258-264.

Mahyuddin, S., A. Azirin, and S. Ponidi (1976). Land equivalent ratio (LER) of corn and mungbean intercropped under varying weed management practices. Paper, $2^{\text {nd }}$ Workshop on Cropping Systems, Central Res. Inst. Agric., Bogor, Indonesia, 10 pp..

Majisu, L. and R. Labelle (1982). A selected bibliography of agroforestry. ICRAF, Nairobi, $60 \mathrm{pp}$.

Makasheva, R. K. H. (1983). Mixed cropping. In The Pea. U. S. Dept. Commerce, Natl. Tech. Information Ser., Springfield, VA, pp. 157-162.

Makena, M. M. and A. L. Doto (1982). Soybean-cereal intercropping and its implications in soybean breeding. Tanzania. Intercrop. Ottawa, pp. 84-90.

Malecha, S. R. and D. R. Onizuka (1981). Polyculture of the freshwater prawn, Macrobrachium rosenbergii, Chinese and common carps in ponds enriched with swine manure. I. Initial trials. Aquaculture 25(2/3):101-116.

Malhotra, O. P. (1980). National demonstrations in Punjab show the way to increased food production. Food Farm. Agric. 13(2):37-39.

Maliwal, P. L. and L. L. Somani (1979). Intercropping with cotton pays dividends. Farmer Parliament. 14(6):21, 28.

Mallarino, A. P. and W. F. Wedin (1990). Nitrigen fertilization effects on dinitrogen fixation as influenced by legume species and proportion in legume-grass mixtures in Uruguay. Plant Soil 124:127-135.

Mallarino, A. P. and W. F. Wedin (1990). Seasonal distribution of topsoil ammonium and nitrate under legume-grass and grass swards. Plant Soil 124:137-140.

Mallarino, A. P., W. F. Wedin, C. H. Perdomo, et al. (1990). Nirogen transfer from white clover, red clover, and birdsfoot trefoil to associated grass. Agronomy J. 82:790-795.

Mallarino, A. P., W. F. Wedin, R. D. Voss, and C. P. West (1983). Phosphorus requiremments of alfalfasmooth bromegrass-orchardgrass and reed canarygrass pastures under two grazing pressures. Agronomy J. 75:291-294.

Mallarino, A. P., W. F. Wedin, R. S. Goyenola, et al. (1990). Legume species and proportion effects on symbiotic dinitrogen fixation in legume-grass mixtures. Agronomy J. 82:785-789.

Malm, N. R. C. E. Barnes, and W. J. Russell (1970). Forage production from bermudagrass alone and mixed with alfalfa in the Pecos Valley. New Mexico State Univ. Agric Expt. Sta. Res. Rep. 182.

Malvi, G. C., C. S. Saraf, and S. L. Pandey (1988). Effect of intercropping on yield attributes of chickpea and safflower under different soil moisture regimes and population densities. Z. Acker Pflanzenbau 160:224-227.

Mamun, A. B. and M. M. Rahman (1986). Fodder production in the existing cropping system in Bangladesh. Bangladesh J. Anim Sci. 15:19-77.

Mancini M., S. and M. A. Castillo D. (1960). Observaciones sobre ensayos preliminares en el cultivo asociado de feijol de enredadera y mais. Agric. Tropical 16:161-166. 
Mandal, B. K., M. C. Dhara, B. B. Mandal, et al. (1989). Effect of intercropping on the yield components of rice, mungbean, soybean, peanut and blackgram. Z. Acker Pflanzenbau 162:30-34.

Mandal, B. K., R. K. Ghosh, N. C. Das, and A. K. Som-Choudhury (1987). Studies on cotton-based multiple cropping. Expl. Agric. 23:443-449.

Mandal, B. K., S. Dasgupta, and P. K. Ray (1985). Effect of intercropping on yield components of wheat, chick pea and mustard under different moisture regimes. Z. Acker Pflanzenbau J. Agron. Crop Sci. 155:261-267.

Mandimba, G. R. (1995). Contribution of nodulated legumes on the growth of Zea mays L. under various cropping systems. Symbiosis 19:213-222.

Mandimba, G. R., C. Galandzou, and N. Guenguie (1993). Effect of plant population densities on the growth of Zea mays L. and Arachis hypogaea L. in intercropping systems. Biol. Agric. Hort. 10:141-154.

Mani, A. (1989). Effect of interculture of marigold and mustard with acidlime on citrus nematode, Tylenchulus semipenetrans. Crop Nematode Res. Control Proj. 5(4):14-15.

Maniania, N. K. (1991). Potential of some fungal pathogens for the control of pests in the tropics. Insect Sci. Appl. 12:63-76.

Mannering, J. V. and D. R. Griffith (1981). Value of crop rotation under various tillage systems. Agronomy Guide AY-230, Coop. Ext. Serv., Purdue Univ. West Lafayette, IN.

Manrique, E. R., A. R. Rosales, and W. O. Martinez (1983). Response of the sugar cane to the nitrogen, phosphorus and potasium nutrients. I Intercropping sugar cane/maize/beans (Colombia). Rev. Inst. Colomb. Agropecu. 18:167-176.

Mapa, R. B. (1995). Effect of intercropping coconut lands on soil water retention. Biological Agric. Hort. 12:173-183.

Marcovitch, S. (1935). Control of the melon louse by intercropping. Agric. Expt. Sta., Univ. Tennessee, 4 pages.

Marhampatra, I. C., D. M. Leeuwrit, and K. N. Singh (1973). Green Revolution through multiple cropping in Asia. In Multiple Cropping and Mechanization, Agric. Mech, Asia.

Mariga, I. K. and T. W. Katsvairo (1996). Maize/bean intercropping on the Zimbabean highveld. Annual Report (H. F. Schwartz), Colo. State Univ. 39:170-171.

Marking, S. (1987). Straw stubble stunts doublecrop soybeans. Soybean Digest 47(10):8-9.

Marshall, B. and R. W. Willey (1983). Radiation interception and growth in an intercrop of pearl millet/groundnut. Field Crops Res. 7:141-160.

Marshall, D. R. and A. H. D. Brown (1973). Stability of performance of mixtures and multilines. Euphytica 22:405-412.

Marten, G. C. (1964). Visual estimation of botanical composition in simple legume-grass mixtures. Agronomy J. 56:549-552.

Marten, G. C. and R. M. Jordan (1979). Substitution value of birdsfoot trefoil for alfalfa-grass in pasture systems. Agronomy J. 71:55-59.

Martin, C. C. (1996). Weed control in tropical ley farming systems: a review. Aust. J. Expl. Agric. 36:1013-1023.

Martin, G. W. and J. T. Touchton (1983). Legumes as a cover crop and source of nitrogen. J. Soil Water Conserv. 38:214-216.

Martin, M. M. and J. Harding (1981). Evidence for the evolution of competition between 2 species of annual plants. Evolution $35(5): 975-987$.

Martin, M. P. L. D. and R. W. Snaydon (1982). Intercropping barley Hordeum sativum and beans Vicia faba. 1. Effects of planting pattern. Expl. Agric. 18(2)139-148.

Martin, M. P. L. D. and R. W. Snaydon (1982). Root and shoot interactions between barley Hordeum sativum and field beans Vicia faba when intercropped. J. Appl. Ecol. 19(1):263-272.

Martin, N. P., C. C. Sheaffer, D. L. Wyse, and D. A. Schriever (1983). Herbicide and planting date influence establishment of sod-seeded alfalfa. Agronomy J. 75:951-955.

Martin, R. C., H. C. Voldeng, and D. L. Smith (1990). Intercropping corn and soybean for silage in a cool-temperate region: yield, protein, and economic effects. Field Crops Res. 23:295-310. 
Martin, R. C., J. T. Arnason, J. D. H. Lambert, et al. (1989). Reduction of European corn borer (Lepidoptera: Pyralidae) damage by intercropping corn with soybean. J. Econ. Entomol. 82:14551459.

Martinez, J. and G. Guiraud (1990). A lysimeter study of the effects of a ryegrass catch crop, during a winter wheat/maize rotation, on nitrate leaching and on the following crop. J. Soil Sci. 41:5-16.

Marzi, V., A. Ventrelli, and G. De-Mastro (1993). Influence of intercropping and irrigation on productivity of licorice (Glycyrrhiza glabra L.). Acta Hort. 331:71-78.

Mascagni, Jr., H. J. and D. J. Bouquet (1996). Starter fertilizer and planting date effects on corn rotated with cotton. Agronomy J. 88:975-982.

Masiunas, J. B., L. A. Weston, and S. C. Weller (1995). The impact of rye cover crops on weed populations in a tomato cropping system. Weed Sci. 43:318-325.

Mason, S. C., D. E. Leihner, and J. J. Vorst (1986). Cassava-cowpea and cassava-peanut intercropping. III. Nutrient concentrations and removal. Agronomy J. 78:441-444.

Mason, S. C., D. E. Leihner, and J. J. Vorst (1986). Cassava-cowpea and cassava-peanut intercropping. I. Yield and land use efficiency. Agronomy J. 78:43-46.

Mason, S. C., D. E. Leihner, J. J. Vorst, and E. Salazar (1986). Cassava-cowpea and cassava-peanut intercropping. II. Leaf area index and dry matter accumulation. Agronomy J. 78:47-53.

Mathan, K. K. (1989). Changes in soil physical properties after intercropping as against sole cropping. Z. Acker Pflanzenbau 163:248-251.

Mather, K. (1961). Competition and cooperation. Symp. Soc. Expl. Biol. 15:264-281.

Mather, K., J. Hill, and P. D. S. Caligari (1982). Analysis of competitive ability among genotypes of perennial rye grass Lolium perenne. Heredity 48(3):421-434.

Mathur, B. N., V. S. Singh, and N. K. Agrawal (1972). Mixed cropping of cotton with groundnut in irrigated areas of Rajasthan. Indian Agric. 16(1):27-31.

Mathur, B. S. (1975). Intercropping of autumn planted sugarcane with wheat. Indian Sugar. 25(5):405408, 411-413.

Mati, B. M. (1995). The effect of rainfall characteristics on splash erosion under crop covers. Trop. Agric. 72:18-21.

Matondang, H. and A. R. Rangkuti (1978). Padi gogo sebagai tanaman sela di proyek perkebunan rakyat. Bull. Balai Penelitian Perkebunan 9(3):115-124.

Mattei, F. (1967). Coltivazione consociata di mais e fagiolo. Ital. Agric. 104:869-874.

Matteson, P. C. (1982). The effects of intercropping with cereals and minimal permethrin applications on insect pests of cowpea and their natural enemies in Nigeria Vigna unguiculata. Trop. Pest Manage. 28(4):372-380.

Maun, M. A. (1977). Suppressing effect of soybean on barnyardgrass. Can. J. Plant Sci. 57:485-490.

May, K. W. (1982). Effects of planting schedule and intercropping on green gram (Phaseolus aureus) and bulrush millet ( Pennisetum americanum) in Tanzania. Expl. Agric. 18(2):149-156.

May, K. W. and R. Misangu (1982). Genotype evaluations and implications for adapting plant material for intercropping Sesamum, Helianthus, Zea mays, Pennisetum americanum, sorghum. Tanzania. Intercrop. Ottawa. pp. 79-83.

May, K. W. and R. Misangu (1982). Some observations on the effects of plant arrangements for intercropping. Zea mays, Glycine max, soybean, corn, cowpea, Vigna. Intercrop. Ottawa. pp. 37-42.

Mays, D. A. and J. B. Washko (1960). The feasibility of stockpiling legume-grass pasturage. Agronomy J. 52:190-192.

Mazaheri, D. (1979). Intercropping studies with maize and kale. Ph.D. Thesis. Univ. Reading, England.

McArthur, A. T. G. (1970). Influence of diversification on risk in mixed cropping. New Zeal. Agric. Sci. 5(1):9-13.

McBratney, J. M. (1984). Productivity of red clover grown alone and with companion grasses. Grass Forage Sci. 39:167-175.

McBroom, R. L., C. M. Brown, and H. H. Hadley (1981). Double cropping and intercropping. Ill. Res. 23:6-7.

McBroom, R. L., H. H. Hadley, and C. M. Brown (1981). Performance of isogenic soybean lines in monoculture and relay intercropping environments. Crop Sci. 21:669-672. 
McBroom, R. L., H. H. Hadley, C. M. Brown, and R. R. Johnson (1981). Evaluation of soybean cultivars in monoculture and relay intercropping systems. Crop Sci. 21:673-676.

McClain, W. R., P. K. Bollich, and D. C. Huffman (1993). Effects of intercropping crawfish in rice fields. Crowley, La., The Station, Annual Res. Rep. pp. 485-488.

McClelland, C. K. (1928). The effect of interplanted legumes on yields of corn. Arkansas Agric. Expt. Sta. Bull. 229. 19 pp

McCreary, N. J., S. R. Carpenter, and J. E. Chaney (1983). Coexistence and interference in 2 submersed fresh water perennial plants. Oecologia 59(2-3):393-396.

McDowell, C. R. and E. J. Moll (1981). Studies of seed germination and seedling competition in Virgilia oroboides, Albizia lophantha and Acacia longifolia. J. S. Afr. Bot. 47(4):653-686.

McGilchrist, C. A. (1965). Analysis of competition experiments. Biometrics 21:975-985.

McGilchrist, C. A. and B. R. Trenbath (1971). A revised analysis of plant competition experiments. Biometrics 27:659-671.

McGill, J. A., Jr. (1983). Dry bean production in Brazil with maize. Mich. Dry Bean Dig. 7(3):10-12.

McGill, W. B., K. R. Cannon, J. A. Robertson, and F. D. Cook (1986). Dynamics of soil microbial biomass and water-soluble organic $\mathrm{C}$ in Breton $\mathrm{L}$ after 50 years of cropping two rotations. Can. J. Soil Sci. 66:1-19.

McGinnies, W. J. and C. E. Townsend (1983). Yield of three range grasses grown alone and in mixtures with legumes. J. Range Mgt. 36:399-401.

McHarvey, M. J. and G. Kapusta (1979). Herbicide application in tillered wheat for doublecrop soybean weed control. Agronomy J. 71:1051-1055.

McIntire, J. (1983). Two aspects of farming in SAT Upper Volta. animal traction and mixed cropping. ICRISAT, $48 \mathrm{pp}$.

McIntire, J. and L. K. Fussell (1989). On-farm experiments with millet in Niger: crop establishment, yield loss factors and economic analysis. Expl. Agric. 25:217-233.

McIntire, J. and L. K. Fussell (1989). On-farm experiments with millet in Niger: crop establishment, yield loss factors and economic analysis. Farm. J. 25:217-233.

McIntosh, J. L., Z. Harahap, and B. H. Siwi (1984). Asian upland rice cropping systems. In An Overview of Upland Rice Research. Intl. Rice Res. Inst., Los Banos, Philippines, pp. 503-509.

McKay, H. C., W. A. Moss, and G. O. Baker (1952). Wheat production in the semiarid Pacific Northwest as influenced by methods and handling of sweet clover as a green manure crop. Agronomy J. 44:247-251.

McKay, K. A., D. E. Radcliffe, and W. L. Hargrove (1989). Winter legume effects on soil properties and nitrogen fertilizer requirements. Soil Sci. Amer. J. 53:1856-1862.

McKee, G. W. (1962). Effects of shading and plant competition on seedling growth and establishment of birdsfoot trefoil. Pennsylvania Agric. Expt. Sta Bull. 689.

McKenzie, H. and M. N. Grant (1980). Survival of common spring wheat cultivars in mixtures in three environments. Can. J. Plant Sci. 60:1309-1313.

McKibben, G. E. and J. W. Pendleton (1968). Double-cropping in Illinois. Ill. Res. 10:6-7.

McKinnon, D. (1982). Intensive mixed cropping with a difference. New Zealand includes sheep farming. N. Z. Farmer 103(17):111-113.

McLaren, J. B., R. J. Carlisle, H. A. Fribourg, and J. M. Bryan (1983). Bermudagrass, tall fescue, and orchardgrass pasture combinations with clover or $\mathrm{N}$ fertilization for grazing steers. I. Forage growth and consumption, and animal performance. Agronomy J. 75:587-592.

McNeel, J. F. and W. B. Stuart (1984). Feasibility of agri-silviculture for pine plantations in the south. Amer. Soc. Agric. Eng., The Society, Issue 84-1609, 14 pp.

McVickar, M. H., E. T. Batten, E. Shulkcum, et al. (1946). The effect of cover crops on certain physical and chemical properties of Onslow fine sandy loam. Soil Sci. Soc. Amer. J. 10:47-49.

McWhorter, C. G. and E. E. Hartwig (1972). Competition of johnsongrass and cocklebur with six soybean varieties. Weed Sci. 20:56-59.

McWhorter, C. G. and J. M. Anderson (1979). Hemp sesbania (Sesbania exaltata) competition in soybeans (Glycine max). Weed Sci. 27:58-64.

McWhorter, C. G. and W. L. Berrentine (1975). Cocklebur control in soybeans as affected by cultivar, seeding rates, and method of weed control. Weed Sci. 23:386-390. 
Mead, R. (1979). Competition experiments. Biometrics 35:41-54.

Mead, R. (1986). Statistical methods for intecropping. In Multiple Cropping Systems (ed: C. A. Francis), Macmillan, New York, pp. 317-350.

Mead, R. and J. Riley (1981). A review of statistical ideas relevant to intercropping research (with discussion). J. Royal Statistical Soc., Ser. A, 144:462-509.

Mead, R. and R. D. Stern (1976). Statistical considerations in experiments to investigate intercropping. In Proc. Intl. Workshop on Intercropping (ed: R. W. Willey). Intl. Crop Res Inst. Semi-Arid Tropics, Patancheru, Andra Pradesh, India, pp. 263-276.

Mead, R. and R. D. Stern (1980). Designing experiments for intercropping research. Expl. Agric. 16(4):329-342.

Mead, R. and R. W. Willey (1980). The concept of a 'land equivalent ratio' and advantages in yields from intercropping pigeonpeas, sorghum. Expl. Agric. 16(3):217-228.

Mead, R., J. Riley, K. Dear, and S. P. Singh (1984). Stability comparison of intercropping and monocropping systems. Biometrics 42:253-266.

Meckenstock, D. H., M. T. Castro, H. N. Pitre, and F. Gomez (1991). Antibiosis to fall armyworm in Honduran landrace sorghum. Environ. Entomol. 20:1259-1266.

Meenakshi, K., A. K. F. Khan, and R. Appadurai (1974). Studies on intercropping of short duration vegetables with maize. Madras Agric. J. Coimbatore 61(8):398-401.

Meese, B. G., P. R. Carter, E. S. Oplinger, and J. W. Pendelton (1991). Corn/soybean rotation effect as influenced by tillage, nitrogen, and hybrid/cultivar. J. Prod. Agric. 4:74-80.

Mehan, V. K., S. N. Nigam, and D. McDonald (1993). Management of bacterial wilt of groundnut using

- genetic resistance and cultural practices. Australian Centre Intl. Agric. Res. (ACIAR) Proc., Canberra, pp. 211-218.

Mehrotra, O. N. and S. A. Ali (1970). Studies on mixed cropping of barley and gram. Indian J. Agron. 15(3):277-280.

Mehta, H., S. K. Sharma, and N. D. Rana (1986). Genetic variability, interrelationships and path coefficient analysis of seed technological traits in soybean under different cropping systems. Soybean Genet. Newsl., The Service 13:77-83.

Meisinger, J. J., W. L. Hargrove, R. L. Mikkelson, et al. (1991). Effects of cover crops on ground water quality. In Cover Crops for Clean Water (ed: W. L. Hargrove). Soil Water Conserv. Soc., Ankeny, Iowa, pp. 57-68.

Melo, W. J. and M. A. B. Kanesiro (1979). A cultura intercalada Sorghum bicolor L. Moench $x$ Dolichos lablab L. 1. Efeitos sobre o desenvolvimento e a producao. Cientifica. Jaboticabal, Brazil, Faculdade de Ciencias Agrarias e Veterinarias "Campus" de Jaboticabal 7(1):101-107.

Memon, A. M. and M. A. Malik (1980). Effects of mixed cropping on seed cotton yield and other economic characters of Pakistan upland cotton. Lahore, Pakistan Assoc. Advancement Sci. 32(1/2)4:95-98.

Menchaca, L. and J. Connolly (1990). Species interference in white clover-ryegrass mixtures. J. Ecology 78:223-232.

Mendosa, T. C. (1990).. Development of organic faming practices for sugarcane based farms. In Agricultural Alternatives and Nutritional Self-sufficiency for a Sustainable Agricultural System That Respects Man and His Environment. Proc. IFOAM Seventh Intl. Sci. Conf., pp. 189-202.

Mendoza, T. C. and E. L. Rosario (1979). Optimum spatial arrangement in sugarcane legume intercropping. J. Crop Sci. 4(4):166-176.

Menegay, M. R., J. N. Hubbell, and R. D. William (1978). Crop intensity index: A research method of measuring land use in multiple cropping. Hort. Sci. 13:8-11.

Mercado, B. L. (1976). Weed control problems in the rice-based multiple cropping systems. Paper, $7^{\text {th }}$ Annual Conf. Pest Control Council of Philippines, Cagayan de Oro City, Philippines.

Mercurio, J. C. and D. D. Buhler (1985). No-till corn production in mixed alfalfa-perennial grass sod. Proc. North Central Weed Control Conf. 40:47.

Meuku, W. A. B. and O. T. Edje (1982). Effect of mixed cropping of maize and bean on bean diseases. Ann. Rep. Bean Improv. Coop., Geneva, N. Y., 25:16-18. 
Meyer, D. W. (1987). Influence of green-manured, hayed, or grain legumes on grain yield and quality of following barley crop in the northern Great Plains. In The Role of Legumes in Conservation Tillage Systems (ed: J. F. Power). Proc. Natl. Conf., Soil Conserv. Soc. Amer., Ankeny, Iowa, pp.94-95.

Miah, M. N. I. and V. R. Carangal (1980). Evaluation of mung bean cultivars under monoculture and intercropping systems. Int, Rice Res. Newsl. 5(2):21-22.

Michael, A. M. (1973). Increasing water use efficiency in multiple cropping. Agric. Mech. Asia. 4:113$117,105$.

Miller, D. A. (1996). Allelopathy in forage crop systems. Agronomy J. 88:854-859.

Miller, M. F. and F. L. Duley (1921). The rate of accumulation of nitrogen and carbon in soils under different systems of green manuring and cropping. Missouri Agric. Expt. Sta. Bull. 189. Columbus.

Miller, M. F. and H. H. Krusekopf (1932). The influence of system of cropping and methods of culture on surface runoff and soil erosion. Missouri Agric. Expt. Sta. Bull. 177.

Miller, S. F. (1976). Weed control systems for representative farms in developing countries. Tech. Rep., Intl. Plant Production Center, Oregon State Univ., Corvallis, 118 pp.

Mills, N. J. (1990). Biological control, a century of pest management. Bull. Entomol. Res. 80:359-362.

Milne, J. A., J. Hodgson, R. Thompson, et al. (1982). The diet ingested by sheep grazing swards differing in white clover and perennial ryegrass content. Forage Grass Sci. 37:209-218.

Milthorpe, F. L. (1961). The nature and analysis of competition between plants of different species. In Mechanisms in Biological Competition. Symp. Soc. Expl. Biol., No. XV, Academic Press, New York, pp. 330-355.

Mir, Z., P. S. Mir, S. Bittmann, and L. J. Fisher (1992). Ruminal degradation characteristics of corn and

- corn-sunflower intercropped silages prepared at two stages of maturity. Can. J. Animal Sci. 72:881889.

Miracle, M. P. (1967). Agriculture in the Congo Basin. Univ. Wisconsin Press, Madison, WI, 355 pp.

Mirchandi, T. J. and D. K. Misra (1957). Associated growth of cereals and legumes. Indian J. Agron. 1:237-243.

Misbahulmunir, M. Y., D. J. Sammons, and R. R. Weil (1989). Corn-peanut intercrop performance in relation to component crop relative planting dates. Agronomy J. 81:184-189.

Mishra, M. N. and L. Singh (1978). Selection gains in Bengal chickpeas, includes intercropping. Indian J. Genet. Plant Breed. 38:86-89.

Mishra, M. N. and Pramodkumar. (1979). Effect of intercropping on genetic variability in gram (Cicerarietinum L.) chickpeas. Madras Agric. J. Coimbatore 66(2):84-88.

Mitchell, A. R. (1996). Peppermint relay intercropping with rye. J. Sustainable Agric. 7:103-110.

Mitchell, C. C., R. L. Westerman, J. R. Brown, and T. R. Peck (1991). Overview of long-term agronomic research. Agronomy J. 83:24-29.

Mitchell, Jr., C. C. (1988). New information from Old Rotation. Highlights Agric. Res. 35(4), Alabama Agric. Expt. Sta., Auburn Univ.

Mitchell, Jr., C. C. (1989). A look at 75 years of fertilization and cropping. Better Crops Plant Food 73:18-19.

Mitchell, R. L., J. B. McLaren, and H. A. Fribourg (1986). Forage growth, consumption, and performance of steers grazing bermudagrass and fescue mixtures. Agronomy J. 78:675-680.

Mitchell, W. H. and M. R. Teel (1977). Winter annual cover crops for no-tillage corn production. Agronomy J. 69:569-573.

Mmbaga, M. E. T. and O. T. Edje (1992). Effects of distance of bean rows from maize rows on yield of both crops grown in association. Annul Rep. Bean Improv. Coop., Colorado State Univ., 35:173174.

Mmbaga, M. E. T. and O. T. Edje (1992). Effects of maize planting pattern on maize and bean productivity in an intercrop. Annul Rep. Bean Improv. Coop., Colorado State Univ., 35:171-172.

Moav, R., G. Wohlfarth, G. L. Schroeder, G. B. Hulata, and H. Arash (1977). Intensive polyculture of fish in freshwater ponds. I. Substitution of expensive feeds by liquid cow manure. Aquaculture 10:2543.

Mohamed, H. M. H. and M. I. M. Salwau (1994). Effect of intercropping cotton with maize under different nitrogen rate and different hill spacing of maize. Natl. Cotton Council Amer., Proc., Memphis, pp. 1570-1572. 
Mohamed-Saleem, M. A. (1985). Effect of sowing time on grain and fodder potential of sorghum undersown with stylo in the subhumid zone of Nigeria. Trop. Agric. (Trinidad) 62:151-153.

Mohammed, E. S. (1978). Early competition between redroot pigweed and tomato. Ph.D. Thesis. Cornell Univ.

Mohammed, M. S. and M. D. Clegg (1993). Pearl millet-soybean rotation and nitrogen fertilizer effects on millet productivity. Agronomy J. 85:1009-1013.

Mohta, N. K. and R. De (1980). Intercropping maize and soybeans with soya bean. J. Agric. Sci. (Camb.) 95:117-122.

Moncada de la Fuente, J. M. (1965). Influence of leguminous plants on the growth and nitrogen nutrition of associated grasses. Ph.D. Thesis, North Carolina State Univ., Raleigh.

Mongi, H. O., A. P. Uriyo, Y. A . Sudi, and B. R. Singh (1976). An appraisal of some intercropping methods in terms of grain yield, response to applied phosphorus and monetary return from maize and cowpeas. E. Afr. Agric. For. J. 2:66-70.

Monks, D. W. and L. R. Oliver (1988). Interactions between soybean (Glycine max) cultivars and selected weeds. Weed Sci. 36:770-774.

Monsi, M. and T. Saeki (1953). Uber den Lichtfaktor in den Pf lanzengesell-schaften und seine Bedeutung fur die Stoffproduktion. Japanese J. Botany 14:22-52.

Montandon, R. and J. E. Slosser (1996). Relay cropping: effect of predators in cotton. Proc. Natl. cotton Council Amer., pp. 786-788.

Montero, W. R-, D. C. K. Lieber, and P. Onoro (1984). Performance in association of cultivars of cassava (Manihot esculenta Crantz) and cowpea (Vigna unguiculata Walp.) of different growth habits. Proc. Sixth Symp. Intl. Soc. Trop. Root Crops, Intl. Potato Center (CIP), pp. 287-294.

Montgomery, C. R., B. D. Nelson, M. Allen, et al. (1983). Evaluation of Pensacola bahiagrass and Alicia bermudagrass with and without interplanted ryegrass and red clover. Louisiana Agric. Expt. Sta. Bull. 748.

Monyo, J. H., A. D. R. Ker, and M. Campbell (1976). Intercropping in Semi-Arid Areas: Report of a Symposium Held at the Faculty of Agriculture, Forestry and Veterinary Science, Univ. Dar es Salaam, Morogoro, Tanzania, Intl. Dev. Res. Centre, Ottawa.

Moody, K. (1973). Weed control in tropical grain legumes. Proc. First IITA Grain legume Improvement Workshop. IITA, Ibadan, Nigeria, pp. 162-183.

Moody, K. (1977). Weed control in multiple cropping. Proc. Symp. on Cropping Systems Res. Dev. Asian Rice Farmer, IRRI, Los Banos, Laguna, Philippines. pp. 281-294.

Moody, K. (1978). Weed control in intercropping in tropical Asia. Paper, Intl. Weed Sci. Conf., IRRI, Los Banos, Laguna, Philippines.

Moody, K. and S. V. R. Shetty (1978). Weed management in intercropping systems. This Workshop.

Mooers, C. A. (1927). Influence of cowpea crop on yield of corn. Univ. Tennesee Agric. Expt. Sta. Bull . $137,18 \mathrm{pp}$.

Moog, F. A. (1986). Forages in integrated food cropping systems. Australian Centre Intl. Agric. Res. (ACIAR), pp. 152-156.

Moolani, M. K., E. L. Knake, and F. W. Slipe (1964). Competition of smooth pigweed with corn and soybeans. Weeds 12:126-128.

Moomaw, R. S. and A. R. Martin (1990). No-till corn in alfalfa sod. Nebguide G74-131, Univ. Nebraska Coop. Ext. Serv., Lincoln.

Moomaw, R. S. and T. A. Powell (1990). Multiple cropping systems in small grains in northeast Nebraska. J. Prod. Agric. 3:569-576.

Moore, K. J., C. A. Roberts, and J. O. Fritz (1990). Indirect estimation of botanical composition of alfalfasmooth bromegrass mixtures. Agronomy J. 82:287-290.

Moore, K. J., V. L. Lechtenberg, R. P. Lemenager, et al. (1985). In vitro digestion, chemical composition, and fermentation of ammoniated grass and grass-legume silage. Agronomy J. 77:758-763.

Mooso, G. D. and W. F. Wedin (1990). Yield dynamics of canopy components in alfalfa-grass mixtures. Agronomy J. 82:696-701.

Morachan, Y. B. and N. Kamalam (1977). A note on the studies on intercropping in sorghum with pulses. Madras Agric. J. Coimbatore 64(9):607-608. 
Moraes, L. T. (1977). Estudio sobre la competencia de nalezas en la association maiz-frijol. M. S. Thesis. Univ. Nacica, Bogota, Colombia.

Moraghan, J. T. and L. J. Smith (1996). Nitrogen on sugar-beet tops and the growth of a subsequent wheat crop. Agronomy J. 88:521-526.

Morales, M. F. M. (1993). Estimation and design of yield-density models for intercropping experiments. $\mathrm{Ph} . \mathrm{D}$. Thesis, Univ. California, Riverside.

Moreno R., O., A. Turrent F., and R. S. Nunez (1973). Las asociaciones de maiz-frijol, una alternativa en el uso de les recursos de los agricultores del Plan Puebla. Agrociencia 14:103-117.

Moreno, R. A. (1979). Crop protection implication of cassava intercropping. CATIE, Turrialba, $38 \mathrm{pp}$.

Moreno, R. A. (1979). Crop protection implications of cassava intercropping. Intl. Dev. Res. Centre, Ottawa, pp. 113-127.

Moreno, R. A. (1982). Intercropping with sweet potato (Ipomoea batatas) in Central America. Shanhua, Taiwan. pp. 243-254.

Moreno, R. A. and R. D. Hart (1979). Intercropping with cassava in Central America common bean. Intl. Dev. Res. Centre, Ottawa, pp. 17-24.

Morgado, L. B. (1986). Some concepts and experimental methods in intercropping research. EMBRAPA, Centro de Pesquisa Agropecuaria do Tropico Semi-Arido, 79 pp.

Morgado, L. B. and T. M. R. de Souza. (1980). Centro de Pesquisa Agropecuaria do Tropics Semi-Arido. Bibliorafia Sinaletica Sohre Culturas Consorciadas. EMBRAPA, Brasilia, 117 pp.

Morgan, W. B. (1959). Agriculture in Southern Nigeria. Economic Geography 35:138-150.

Morgan, W. B. (1959). The influence of European contact on the southern Nigeria. Geogr. J. 125:48-64.

Morgan, W. B. (1969). Peasant agriculture in tropical Africa. In Environment and Land Use in Africa (ed: M. F. Thomas and G. W. Wittington). Methuen and Co., Ltd., London, pp. 241-272.

Morgan, W. B. and J. C. Pugh (1969). West Africa. Methuen and Co., Ldt, London.

Morishima, H. and Y. Sano (1983). Neighbor effects observed in inter-and intra-specific mixtures of rice: a review and presentation of new data. In Frontiers of Research in Agriculture: Proc. (ed: S.K. Roy), Calcutta, pp. 287-303.

Morris, D. R., R. W. Weaver, G. R. Smith, and F. M. Rouquette (1990). Nitrogen transfer from arrowleaf clover to ryegrass in field plantings. Plant Soil 128:293-297.

Morris, D. R., R. W. Weaver, G. R. Smith, and F. M. Rouquette (1986). Competition for nitrogen-15depleted ammonium nitrate between arrowleaf clover and annual ryegrass sown into bermudagrass sod. Agronomy J. 78:1023-1030.

Morris, H. D: and E. L. Reese (1962). Effect of varying levels of nitrogen on forage yield of several rye varieties and rye mixtures. Agronomy J. 54:155-157.

Morris, R. A., A. N. Villegas, A. Polthance, and H. S. Centeno (1990). Water use by monocropped and intercropped cowpes and sorghum grown after rice. Agronomy J. 82:664 -668.

Morris. R. A., R. E. Furoc, and M. A. Dizon (1986). Rice response to a short duration green manure. I. Grain yield. Agronomy J. 78:409-412.

Morrish, R. H. (1934). Crop mixture trials in Michigan. Michigan State Coll. Agric. Expt. Sta. Special Bull. 256.

Morzadec, H. Le. and A. Pousset (1982). Fertilisation en polyculture associee a l'elevage. Agriculture. Paris. No. 463. pp. 159-160.

Moschler, W. W., G. D. Jones, R. R. Wilmouth, and G. M. Shear (1973). Rotations for no-tillage corn in Virginia. Virginia Polytech. Inst. State Univ., Res. Div. Rep. 147:1-13.

Moschler, W. W., G. M. Shear, D. L. Hallock, et al. (1967). Winter cover crops for sod-planted corn: Their selection and management. Agronomy J. 59:547-551.

Motazedian, I. and S. H. Sharrow (1986). Defoliation effects on forage dry matter production of a perennial ryegrass-subclover pasture. Agronomy J. 78:581-584.

Mott, G. O. and H. L. Lucas (1953). The design, conduct and interpretation of grazing trials on cultivated and improved pastures. Proc. VI Intl. Grassl. Congress, Pennsylvania State College, State College, pp. 1340-1345.

Mount, M. C. H. and T. W. Walker (1959). Competition for nutrients between grasses and white clover. I. Effect of grass species and nitrogen supply. Plant and Soil 11:30-40. 
Mouttapa, F. (1973). Soil aspects of shifting cultivation. FAO/SIDA Regional Seminar on Shifting Cultivation and Soil Conservation in Africa, Ibadan, Nigeria.

Mowers, R. P., W. A. Fuller, and W. D. Shrader (1981). Comparison of meadow-kill treatments on cornoats-meadow-meadow rotation in northwestern Iowa. Iowa Agric. Expt. Sta. Res. Bull. 593.

Moyer, J. R. (1985). Effect of weed control and a companion crop on alfalfa and sainfoin establishment, yields and nutrient composition. Can. J. Plant Sci. 65:107-116.

Muckle, T. B. (1971). Farming in Sierra Leone. Agriculture 78(4):171-174.

Mueller, J. P. and D. S. Chamblee (184). Sod-seeding of ladino clover and alfalfa as influenced by seed placement, seeding date, and grass suppression. Agronomy J. 76:284-289.

Mueller, J. P., W. M. Lewis, J. T. Green, and J. C. Burns (1993). Yield and quality of corn silage corn as altered by johnsongrass infestation. Agronomy J. 85:49-52.

Mueller-Warrant, G. W. and D. W. Koch (1980). Establishment of alfalfa by conventional and minimum tillage seeding techniques in a quackgrass-dominant sward. Agronomy J. 72:884-889.

Mukundan, G. and S. Balakrishnan (1987). Integration of small ruminants and tree cropping in South India. In Small Ruminant Production Systems in South and Southeast Asia (ed: C. Devendra). Proc. Workshop, Bogor, Indonesia, pp. 175-189.

Mumaw, C. R. and C. R. Weber (1957). Competition and natural selection in soybean varietal composites. Agronomy J. 49:154-160.

Munawar, A., R. L. Blevins, W. W. Frye, and M. R. Saul (1990). Tillage and cover crop management for soil water conservation. Agronomy J. 82:773-777.

Murphy, H. J., P. N. Carpenter, and M. J. Goven (1967). Potato fertilization-rotation studies on Aroostock Farm permanent fertility plots. Maine Agric. Expt. Sta. Bull 645 .

Murphy, J. P. and R. J. Frey (1983). Double cropping of soybeans and corn with spring-sown oats. Iowa State J. Res. 57(3):245-258.

Murphy, J. P., L. D. Robertson, and K. J. Frey (1983). Double cropping of soybeans and corn with springsown oats (Zea mays, Glycine max, Avena sativa, No-till planting, intercropping, Iowa). Iowa State J. Res. 57: 245-258.

Murphy, D. P. L., M. H. Dahab, G. C. L. Wyseure, and J. R. O'Callaghan (1994). The simulation of the effects of shading on the growth and yield of winter barley (Hordeum distichum). Computers Electronics Agric. 11:351-365.

Murray, A. (1976). Africa. Collins, London.

Murray, G. A. and J. B. Swensen (1984). Intercropping Austrian winter peas and winter cereals for seed. Idaho Univ. Coop. Ext. Serv., The Service, Issue 749, 4 pp.

Murray, G. A. and J. B. Swensen (1985). Seed yield of Austrian winter field peas intercropped with winter cereals. Agronomy J. 77:913-916.

Murray, G. A., D. L. Auld, and J. B. Swensen (1984). Winter pea-winter cereal mixtures as potential forage crops in northern Idaho. Univ. Idaho Expt. Sta. Bull. 638.

Musande, V. G. and D. N. Borulkar (1981). Developing a cropping system for G. Cot. 10 cotton variety, intercropping and fertiliser levels. J. Maharashtra Agric. Univ. Pune. 6(3):258-260.

Musande, V. G. and D. N. Borulkar (1982). Dry matter accumulation pattern in cotton (var. G. Cot. 10) under different intercropping systems. J. Maharashtra Agric. Univ. Pune. 7(1):92

Musande, V. G. and D. N. Borulkar (1982). Flowering and fruiting behaviour of cotton (var. G. Cot. 10) under different intercropping systems. J. Maharashtra Agric. Univ. Pune. 7(1):93-94.

Musande, V. G. and G. M. Potekar (1981). Path coefficient analysis in cotton grown under intercropping system. Plant genetics and selection. Madras Agric. J. Coimbatore 6(1):10-13.

Musande, V. G. and V. D. Sondge (1981). Consumptive use of water, moisture use efficiency and moisture extraction pattern in cotton intercropping. Madras Agric. J. Coimbatore 6(7):431-435.

Musande, V. G., B. N. Chavan, and V. D. Sondge (1981). Consumptive use of water, moisture use efficiency and moisture extraction pattern in cotton intercropping. Madras Agric J. 68:431-435.

Musande, V. G., B. N. Chavan, V. D. Sondge, and D. N. Borulkar (1982). Dry matter accumulation pattern in cotton (var. G. Cot. 10) under different intercropping systems (Gossypium hirsutum, India). J. Maharashtra Agric. Univ. 7:92. 
Musande, V. G., B. N. Chavan, V. D. Sondge, and D. N. Borulkar (1982). Flowering and fruiting behaviour of cotton (var. G. Cot. 10) under different intercropping systems (India). J. Maharashtra Agric. Univ. 7:93-94.

Musoke, R. (1987). A preliminary Sesbania seed study in Uganda. Rep Swed Univ Agric Sci Dep For Genet Plant Physiol. issue 7, pages 210-215.

Mutsaer, J. A. (1978). Mixed cropping experiments with maize and groundnuts. Neth. J. Agric. Sci. 26:344-353.

Mutsaers, H. J. W. (1978). Mixed cropping experiments with maize and groundnuts in the Yaounde area, Cameroon. Neth. J. Agric. Sci. 26(4):344-353.

Mwaja, V. N., J. B. Masiunas, and L. A. Weston (1995). Effects of fertility on biomass, phytotoxicity, and allelochemical content of cereal rye. J. Chem. Ecology 21:81-96.

Myaka, F. A. (1995). Effect of time of planting and planting pattern of different cowpea cultivars on yield of intercropped cowpea and maize in tropical sub-humid environment. Trop. Sci. 35:274-279.

Myaka, F. A. and J. C. B. Kabissa (1996). Fitting short duration cowpea into a cotton-based cropping system in Tanzania: effect of planting pattern, time of planting cowpea, and insecticide application to the cotton. Expl. Agric. 32:225-230.

Myers, J. L. and M. G. Wagger (1991). Reseeding potential of crimson clover as a cover crop for notillage corn. Agronomy J. 83:985-991.

Myers, R. J. K.(1987). Food legumes in the nitrogen cycle of farming systems. Australian Centre Intl. Agric. Res. (ACIAR), pp. 46-52.

Nabhan, G. P., R. Robichaux, M. Slater, and M. Nelson (1988). Useful desert plants for low-input polycultures. Arid Lands Newsl. 27:11-14.

Nadal, A. M. and V. R. Carangal (1977). Promising varieties of corn, sorghum and soybean evaluated at zero tillage conditions after lowland rice. Paper, $8^{\text {th }}$ Annual Convention Crop Sci. Soc. Philippines, $14 \mathrm{pp}$.

Nadar, H. M. (1982). Intercropping under marginal rainfall conditions in Kenya. Intercrop. Ottawa. pp 50-55.

Nadar, H. M. and G. E. Rodewald (1982). Interaction between agronomic research and agricultural economic analysis to develop successful dryland cropping systems in Kenya. Intercrop. Ottawa. p. 146-154.

Nafus, D. And I. Schreiner (1986). Intercropping maize and sweet potatoes. Effects on parasitization of Ostrinia furnacalis eggs by Trichogramma chilonis. Agric. Ecosyst. Environ. 15:189-200.

Nafziger, E. D., R. L. Mulvaney, D. L. Mulvaney, and L. E. Paul (1984). Effect of previous crop on the response of corn to fertilizer nitrogen. J. Fert. Issues 1:136-138.

Nagaraj, B. (1974). Intercropping in arecanut gardens of 'Maidan' areas of Karnataka. Arecanut Spices Bull. 5( 3):78-79.

Nageswara Reddy, M. and B. N. Chatterjee (1975). Mixed cropping of soybean with maize. Indian J. Agron. 20(4):341-345.

Nageswara Reddy, M. and G. H. Sankara Reddi (1979). Studies on intercropping in pigeonpea. Agric. Agroind. J. 12(1):26-27.

Nageswara-Rao, R. C., K. D. R. Wadia, and J. H. Williams (1990). Intercropping short and long duration groundnut (Arachis hypogaea) genotypes to increase productivity in environments prone to end-ofseason droughts. Expl. Agric. 26:63-72.

Nair, K. P. P. and M. K. Kaushik (1979). Evaluation of legume intercropping in conservation of fertilizer nitrogen in maize culture. J. Agric. Sci. 93(1):189-194.

Nair, K. P. P., U. K. Patel, R. P. Singh, and M. K. Kaushik (1979). Evaluation of legume intercropping in conservation of fertilizer nitrogen in maize culture. J. Agric. Sci. 93:189-194.

Nair, M. G. (1982). Intercropping with pepper betel nut production. Indian Farming 32(9):17-19.

Nair, P. K. R. and P. T. Varghese (1976). Crop diversification in coconut plantations. Indian Farming 25(11):17-19, 21.

Nair, P. K. R., B. T. Kang, and D. C. L. Kass (1995) Nutrient cycling and soil-erosion control in agroforestry systems. In Agriculture and Environment: Bridging Food Production and Environmental Protection in Developing Countries. Proc. Intl. Symp., ASA, Madison, WI, pp. 117-138. 
Nair, P. K. R., E. C. M. Fernandes, and P. N. Wambugu (1984). Multipurpose leguminous trees and shrubs for agroforestry. Agroforestry Syst. 2:145-163.

Nair, P. K. R., R. Varma and E. V. Nelliat (1974). Intercropping for enhanced profits from coconut plantation. Indian Farming 24(4):11-13.

Nair, R. V., N. C. Pillai, and Sahasranaman. (1976). Mixed farming in coconut gardens. Indian Farming 25(11):24-25.

Nair, S. K. and N. S. S. Rao (1977). Distribution and activity of phosphate solubilising microorganisms in the rhizosphere of coconut and cacao under mixed cropping. J. Plant Crops 5(2):67-70.

Nair, S. K. and N. S. Subba Rao (1977). Microbiology of the root region of coconut and cacao under mixed cropping. Plant Soil 46(3):511-519.

Nambiar, E. K. S. and K. H. Nethercott (1987). Nutrient and water availability to and growth of young radiata pine plantations intercropped with lupins. New For. 1:117-134.

Nambiar, P. T. C. and P. J. Dart (1983). Effect of intercropping on nodulation and N2 nitrogen-fixation by groundnut Arachis hypogaea, peanuts. Expl. Agric. 19(1):79-86.

Nambiar, P. T. C., M. R. Rao. M. S. Reddy et al. (1983). Effect of intercropping on nodulation and nitrogen fixation by groundnut. Expl. Agric. 19:79-86.

Nangju, D. (1973). Progress in grain legume agronomic investigations at IITA. Proc. First IITA Grain Legume Improvement Workshop, IITA, Ibadan, pp. 122-136.

Nangju, D. et al. (1974). Performance of the $19741^{\text {st }}$ and $2^{\text {nd }}$ International cowpeas uniform cultivar trials IITA GLIP.

Nanju, D. (1977). The importance of grain legumes in cropping systems in Africa. Workshop Cropping Systems in Africa, Assoc. Adv. Agric. Sci. Afriea, Addis Ababa, Ethiopia, pp. 63-71.

Narain, P. and A. K. Singhal (1980). Nitrogen economies through intercropping of pigeonpeas in rainfed sorghum. Indian J. Agron. 25(2):190-196.

Narang, S. D., J. N. Kaul and G. S.Gill (1969). Intercropping maize with soybean. Indian Farming 19(6):21.

Narwal, S. S. and D. S. Malik (1981). Effect of intercropping on the growth and yield of sugarcane varieties. Indian Sugar 31(3):193-198.

Narwal, S. S. and K. L. Behl (1978). Effect of intercropping of wheat varieties on the growth and yield of sugarcane. Indian Sugar 28(6):323-327.

Narwal, S. S. and K. L. Behl (1978). Effect of intercropping on the yield of spring planted sugarcane. Indian Sugar 28(1):27-29.

Narwal, S. S. D. S. Malik (1985). Influence of intercropping on the yield and food value of rainfed sunflower and companion legumes. Expl. Agric. 21:395-401.

Nasr, H. G. (1976). Multiple cropping in some countries of the Middle East. In Multiple Cropping (ed: R. I. Papendick et. al). ASA/CSSA/SSSA Spec. Publ. No. 27, Madison, WI, pp. 117-126.

Natarajan, M. and D. M. Naik (1992). Competitive effects of a short duration, bush type cowpea when intercropped with cotton in Zimbabwe. Expl. Agric. 28:409-416.

Natarajan, M. and R. W. Willey (1980). Sorghum-pigeonpea intercropping and the effects of population density: I. Growth and yield. J. Agric. Sci. (Camb.) 95:51-58.

Natarajan, M. and R. W. Willey (1980). Sorghum/pigeon intercropping and effects of plant population density. II. Resource use. J. Agric. Sci. 95:59-65.

Natarajan, M. and R. W. Willey (1981). Growth studies in sorghum/pigeon pea intercropping with particular emphasis on canopy development and light interception. Proc. Intl. Workshop Intercropping. ICRISAT, Hyderbad, India, pp.

Natarajan, M. and R. W. Willey (1985). Effect of row arrangement on light interception and yield in sorghum-pigeonpea intercropping. J. Agric. Sci. 104:263-270.

Natarajan, M. and R. W. Willey (1986). The effects of water stress on yield advantages of intercropping systems. Field Crops Res. 13:117-131.

Natarajan, M. and T. M. Vittal (1975). Promising pulse varieties for intercropping and multiple cropping in Tamilnadu. Indian J. Genet. Plant Breed. 35(2):291-294.

Natarajan, M., J. Kannaiyan, R. W. Willey, and Y. L. Nene (1985). Studies on the effects of cropping system on Fusarium wilt of pigeonpea. Field Crops Res. 10:333-346. 
Navarro, L. A.and D. L. Kass (1985). Economics of intercropping. In World Soybean Research Conference III: Proc. (ed: R. Shibles). pp. 1039-1045.

Nayital, S. C. and C. M. Singh (1984). Effect of crop establishment method, seed rates and nitrogen fertilization on yield, quality and economics of linseed in north-western Himalayas. Indian J. Agric. Sci. 54:659-663.

Nazir, M. S., M. Aslam, M. Siddique. and M. Saeed (1985). Autumn ratooning as influenced by geometry of planting and residual effect of berseem intercropped in autumn planted sugarcane. Pak. J. Bot. 17:81-86.

Ndayi, K. (1984). Factors limiting cassava production among peasants in Lukangu, Zaire. In Tropical Root Crops: Production and Uses in Africa (ed: E.R. Terry. et al.), Proc. $2^{\text {nd }}$ Triennial Symp. Intl. Soc. Trop. Root Crops, Douala, Cameroon, pp. 71-72.

Ndegwe, N. A. (1992). Economics returns from yam/maize intercrops with various stake densities in a high-rainfall area. Trop. Agric. 69:171-175.

Ndon, B. A., R, G. Harvey, and J. M. School (1982). Weed control in double cropped corn, grain sorghum, or soybeans minimum-till following canning peas. Agronomy J. 74:266-269.

Ndunguru, B. J. (1980). Intercropping. Proc. Second Symp. Intercropping in Semi-Arid Areas, Morogoro, Tanzania, Intl. Dev. Res. Centre, Ottawa, Canada, 168 pp.

Ndunguru, B. J. and J. H. Williams (1993). The impact of varying levels of competition from pearl millet on the yields of groundnut cultivars. Expl. Agric. 29:29-37.

Neely, C. L., K. A. McVay, and W. L. Hargrove (1987). Nitrogen contribution of winter legumes to no-till corn and grain sorghum. In The Role of Legumes in Conservation Tillage Systems (ed: J. F. Power). Soil Conserv. Soc. Amer., Ankeny, Iowa, pp. 48-49.

Nelliat, E. V., K. V. Bavappa, and P. K. R. Nair (1974). Multi-storyed cropping. A new dimension in multiple cropping for coconut plantations. World Crops. 26:262-266.

Nelson, C. J., K. M. Hassom, D. A. Sleper, and J. R. Forwood (1989). Compatibility of birdsfoot trefoil with tall fescue selected for high and low leaf expansion rate. Proc. Intl. Grassl. Congr., French Grassland Soc., Nice, pp.467-468.

Nelson, L. R., R. N. Gallaher, M. R. Holmes, and R. R. Bruce (1977). Corn forage production in no-till and conventional tillage double-cropping systems. Agronomy J. 69:635-638.

Nelson, L. R., R. N. Gallaher, R. R. Bruce, and M. R. Holmes (1977). Production of corn and sorghum grain in double-cropping systems. Agronomy J. 69:41-45.

Nelson, M. (1944). Effect of the use of winter legumes on yields of cotton, corn and rice. Arkansas Expt. Sta. Bull. 451.

Nesa, A., A. Hamid, M. H. Mondal, and A. F. M. Maniruzzaman (1989). Effect of planting geometry on the growth and yield performance of maize intercropped with rice. Z. Acker Pflanzenbau 162:166171.

NeSmith, D. S., W. L. Hargrove, D. E. Radcliffe, et al. (1987). Tillage and residue management effects on properties of an ultisol and double-cropped soybean production. Agronomy J. 79:570-576.

Netting, R. McC. (1968). Hill Farms of Nigeria. Univ. Washington Press, Seattle.

Neugebauer, B. (1988). Agricultural development in central Yucatan and its implications for the promotion of intensive diversified land-use systems. In Global Perspectives on Agroecology and Sustainable Agricultural Systems. Proc. Sixth Intl. Sci. Conf. Intl. Fed. Organic Agric. Movements, Univ. California, pp. 297-306.

Neumann, I. F. (1983). Use of trees in smallholder agriculture in tropical highlands. In Environmentally Sound Agriculture: Selected Papers (ed: W. Lockeretz). 4th Conf. Intl. Federation Organic Agric. Movements, Cambridge, Mass., pp. 351-374.

Nevorotov, V. P. (1979). Selection of mixtures for sown pastures in northern Omsk province (in Russian). Sib. Vestn. Skh. Nauki 3:98-99.

Newberry, D. M. and E. I. Newman (1978). Competition between grassland plants at different initial sizes Oecologia 33:361-368.

Newman, E. I. and M. H. Miller (1977). Allelopathy among some British grassland species. II. Influence of root exudates on phosphate uptake. J. Ecol. 65:399-411. 
Newman, R. W. and D. Smith (1972). Influence of two seeding patterns, nitrogen fertilization and three alfalfa varieties on dry matter and protein yields and persistence of alfalfa-grass mixtures. Wisconsin Agric. Expt. Sta. Res. Rep. 2377.

Newman, S. M. (1986). A pear and vegetable interculture system: land equivalent ratio, light use efficiency and productivity. Expl. Agric. 22:383-392.

Newnham, R. (1981). Il s'ppele my name is "polyculture" describes mixed farming in southwest France. N. Z. J. Agric. 142(2):52-53.

Ng, K., K. F. Kwong, G. Umrit, and J. Deville (1996). Nitrogen fertilization of sugarcane in an intercropping system with maize and potato in the humid tropical climate of Mauritius. Expl. Agric. 32:213-218.

Ngugi, C. W. and J. M. K. Ikahu (1990). The effect of intercropping pyrethrum with maize on flower yield and pyrethrins content. Pyrethrum Post 4:140-145.

Nichols, A. L. and R. A. Peters (1983). Sod-seeding birdsfoot trefoil into established orchardgrass with overall or banded herbicides. Can. J. Plant Sci. 63:267-276.

Nichols, R. L., R. A. Peters, and B. G. Mullinix, Jr. (1983). Effects of herbicides and treatment dates on the establishment of sod-seeded red clover, birdsfoot trefoil, and alfalfa. Connecticut (Storrs) Agric. Expt. Res. Rep. 78.

Nicholson, A. G. and H. C. Wein (1983). Screening of turfgrasses and clovers for use as living mulches in sweet corn and cabbage soil compaction. J. Amer. Soc. Hortic. Sci. 108(6):1071-1076.

Nickel, J. L. (1973). Pest situation in changing agricultural systems: A review. Bull. Ento. Soc. Amer. 54:76-86.

Nickel, S. E., R. K. Crookston, and M. P. Russelle (1995). Root growth and distribution as affected by corn-soybean cropping sequence. Agronomy J. 87:895-902.

Nickel, S. E., S. R. Simmons, C. C. Sheaffer, and S. R. Radosevich (1990). Addition series approach to assessing competition in a small grain-alfalfa companion crop community. Crop Sci. 30:11391141.

Nicol, H. (1934). The derivation of the nitrogen of crop plants with special reference to associated growth. Biol. Rev. 9:383-410.

Nicol, H. (1935). Mixed cropping in primitive agriculture. Emp. J. Expl. Agric. 3:189-195.

Nicol, H. (1936). The utilization of atmospheric nitrogen by mixed crops. Part I, Int. Rev. Agric., Agric. Sci. 27:201-216.

Niets, J. N. and D. W. Stainiforth (1961). Corn-foxtail competition under various production conditions. Agronomy J. 53:1-5.

Nijjar, G. S. (1975). Vineyard management with special reference to irrigation, mulching and intercropping in North India. Haryana J. Hortic. Sci. 4(1/2):40-45.

Nikam, S. M., V. G. Patil, N. Y. Patil, and A. B. Deokar (1984). Intercropping of linseed and gram in safflower with different planting patterns. Indian J. Agron. 29:299-304.

Nikam, S. M., V. G. Patil, N. Y. Patil, and A. B. Deokar (1984). Intercropping of linseed and gram in safflower with different planting patterns. Indian J. Agron. 29:225-230.

Niqueux, M. (1959). Choic de varietes d'Arachides au Tchad. III. Essais de culture associee d' arachides er de sorghos au Tchad. I'Agronomie Tropicale 14(4):501-502.

Njoku, B. O. and S. O. Odurukwe (1987). Evaluation of nitrogen fertilizer sources and rates for a cassavamaize intercrop. In Tropical Root Crops: Root Crops and the African Food Crisis, Proc. Third Triennial Symp. Intl. Soc. Trop. Root Crops, pp. 30-33.

Njoroge, J. M. and J. K. Kimemia (1993). Current intercropping observations and future trends in arabica coffee, Kenya. Outlook Agric. 22:43-48.

Njoroge, J. M. and J. K. Kimemia (1995). Economic benefits of intercropping young Arabica and Robusta coffee with food crops in Kenya. Outlook Agric. 24:27-34.

Njoroge, J. M. and J. K. Kimemia (1995). Effects on the yield and growth of a young compact Arabica coffee hybrid of intercropping with food crops in three agro- ecozones in Kenya. Expl. Agric. 31:49-55.

Njoroge, J. M., K. Waithaka, and J. A. Chweya (1993). Effects of intercropping young plants of the compact arabica coffee hybrid cultivar Ruiru 11 with potatoes, tomatoes, beans and maize on coffee yields and economic returns in Kenya. Expl. Agric. 29:373-377. 
Nnadi, L. A. and I. Haque (1986). Forage legume-cereal systems: improvement of soil fertility and agricultural production with special reference to sub-Saharan Africa. In Potentials of Forage Legumes in Farming Systems of Sub-Saharan Africa (ed: I. Haque et al.). Proc. Workshop ILCA, Addis Ababa, Ethiopia, pp. 330-362.

Nnko, E. N. and A. L. Doto (1982). Intercropping maize or millet with soybean, with particular reference to planting schedule. Intercrop., Ottawa. pp. 33-36.

Nobbe, F. and L. Richter (1902). Miteilungen aus der Konigl. Pflanzenphysiologischen Versuchs-Station. Therand. 58. Uber den Einfluss des Nitratstickstoffs und der Humussubstanzen auf den Impfungserfolg bet Leguminosen. Landwirtschaftlichen Versuchs-Station 56:441-448.

Noe, J. P. (1988). Theory and practice of the cropping systems approach to reducing nematode problems in the tropics. J. Nematol. 20:204-213.

Noll, C. F. and R. D. Lewis ( 1921). Soybeans. Pennsylvania Agric. Expt. Sta. Bull. 167. 20 pp.

Norberg, O. S., T. E. Fiez, G. D. Jolliff, et al. (1993). Shading and cover-crop effects on meadowfoam oil yield. Agronomy J. 85:183-187.

Nordquist, P. T. and G. A. Wicks (1974). Establishment methods for alfalfa in irrigated corn. Agronomy J. 66:377-380.

Norman, D. W. (1968). Why practice intercropping? Samaru Agric. Newsl.10:107-116.

Norman, D. W. (1971). Intercropping annual crops under indigenous conditions in the northern part of Nigeria. Rural Economy Res. Unit, Ahmadu Bello Univ., Samaru, Zaria, Nigeria.

Norman, D. W. ( 1973). Crop mixtures under indigenous conditions in northern part of Nigeria. In Factors of Agricultural Growth in West Africa (ed: I. M. Ofori). Inst. Social Economic Res., Univ. Ghana, pp. 130-144.

Norman, D. W. ( 1974). Why practise intercropping? J. Dev. Stud. 11:2-21.

Norman, D. W. (1968). Rationalising mixed cropping under indigenous conditions: the example of northern Nigeria. J. Dev. Stud. 5:3-21.

Norman, D. W. (1972). An economic survey of three villages in Zaria province. II. Input-output relationships. Ahmadu Bello Univ., Samaru, Nigeria.

Norman, D. W. (1973). Incorporating the time dimension; the case of crop mixtures in Northern Nigeria. Paper, Multiple Cropping Workshop, IDRC and IRRI, Los Banos, Philippines.

Norman, D. W. (1974). Rationalizing mixed cropping under indigenous conditions. The example of Northern Nigeria. J. Devel. Stud. 11:3-21.

Norman, D. W. (1975). Rationalising mixed cropping under indigenous conditions: The example of Northern Nigeria. Samaru Res. Bull. 232.

Norman, D. W. (1976). Developing mixed cropping systems relevant to the farmers' environment. In Intercropping in Semiarid Areas (Ed: J. H. Monyo, A. D. R. Ker, and M. Campbell). Univ. Dar es Salaam. Morogoro. Tanzania and IDRC. p. 52.

Norman, D. W., B. J. Buntjer, and A. D. Goddard (1970). Intercropping observation plots at the farmers' level. Samaru Agric. Newsl. 12(6):97-101.

Norwal, S. S. and D. S. Malik (1985). Influence of intercropping on the yield and food value of rainfed sunflower and companion legumes. Expl. Agric. 21:395-401.

Nour, H. A., E. E. Ghafaga, A. M. Ibrahim, A. M., et al. (1971). Sugar cane in United Arab Republic with intercropping bean. Sugar J. 33(11):28-29.

Nowotnowna, A. (1937). An investigation of nitrogen uptake in mixed crops not receiving nitrogenous manures. J. Agric. Sci. 27:504-510.

Ntare, B. R. (1989). Evaluation of cowpea cultivars for intercropping with pearl millet in the Sahelian zone of West Africa. Field Crops Res. 20:31-40.

Ntare, B. R. (1990). Intercropping morphologically different cowpeas with pearl millet in a short season environment in the Sahel. Expl. Agric. 26:41-47.

Ntare, B. R. and A. Bationo (1992). Effects of phosphorus on yield of cowpea cultivars intercropped with pearl millet on Psammentic paleustalf in Niger. Fert. Res. 32:143-147.

Ntare, B. R. and J. H. Williams (1992). Response of cowpea cultivars to planting pattern and date of sowing in intercrops with pearl millet in Niger. Expl. Agric. 28:41-48. 
Nugroho, W. H. (1984). The biometrical analyses of intercropping experimments: Some practical aspects with the reference to Indonesian intercropping experimments. Ph.D. Thesis, Waite Agric. Res. Inst., Univ. Adelaide.

Nuttall, W. F., A. D. Cooke, J. Waddington, and J. A. Robertson. (1980). Effect of nitrogen and phosphorous fertilizer on a bromegrass and alfalfa mixture grown under two systems of pasture management. I. Yield, percentage legume in sward, and soil tests. Agronomy J. 72:289-294.

Nwosu, N. A. (1973). Some indigenous cropping systems of Eastern Nigeria. FAO/SIDA Regional Seminar on Shift Cultivation and Soil Conservation in Africa, Ibadan.

Nye, P. H. and D. J. Greenland (1960). Soils under shifting cultivation. Tech. Com. No. 51. Bureax of Soil - England (Harpenden).

O'Connor, K. F. (1967). Lucerne-grass associations under different sowing and defoliation systems. In The Lucerne Crop (ed: R. H. M. Langer)., A. H. and A. W. Reed Publ., Wellington, New Zealand, pp. 163-176.

O'Sullivan, J. O. (1978). Effects of rotation and nitrogen on yield and quality of potatoes. Can. J. Plant Sci. 58:475-483.

Obenshain, S. S. and P. T. Gish (1941). The effect of green manure crops on certain physical properties of Berks silt loam. Virginia Agric. Expt. Sta. Tech. Bull. 73.

Obiagwu, C. J. (1995). Estimated yield and nutrient contributions of legume cover crops intercropped with yam, cassava, and maize in the Benue River Basins of Nigeria. J. Plant Nutrition 18:2775-2782.

Obiagwu, C. J. and O. O. Agbede (1996). Interactive effects of food legume cover crops on the productivity of sandy soils of Benue River Basins. J. Sustainable Agric. 8:11-20.

Odhiambo, T. R. (1990). Assets of an IPM specialist with particular reference to Chilo. Insect Sci. Appl. 11:571-576.

Odland, T. E. (1930). Soybeans for silage and for hay. West Virginia Univ. Agric. Expt. Sta . Bull. 227, $24 \mathrm{pp}$.

Odland, T. E. and J. E. Sheehan (1957). The effect of redtop and red clover on yields of following crops of potatoes. Amer. Potato J. 34:282-284.

Odo, P. E. (1991). Evaluation of short and tall sorghum varieties in mixtures with cowpea in the Sudan Savanna of Nigeria: Land equivalent ratio, grain yield and system productivity index. Expl. Agric. 27:435-441.

Odongo, J. C. W., D. S. Veresoglou, D. Papakosta, and A. G. Sificas (1988). Biomass and nitrogen yields of intercropped maize and soybeans as affected by applied nitrogen, Rhizobium, maize hybrids and population density. Z. Acker Pflanzenbau 160:38-46.

Oduol, P. A. (1986). The Shamba system: an indigenous system of food production from forest areas in Kenya. Agroforestry Syst. 4:365-373.

Odurukwe, S. O. (1986). Yam maize intercropping investigations in Nigeria. Trop. Agric. 63:17-21.

Odurukwe, S. O. and J. E. G. Ikeorgu (1994). Effects of fertilizer and time of introduction of cassava in yam/maize/cassava intercrop on component yields. Acta Hort. 380:72-77.

OECD (Organisation for Econ. Coop. Dev.). (1977). Report of the steering group on pest control under the conditions of small farmer food crop production in developing countries. OECD (France), 86 pp.

Oelsligle, D. D., R. E. McCollum, and B. T. Kang (1975). Soil fertility management in tropical multiple cropping. In Multiple Cropping (ed: R. I. Papendick, P. A. Sanchez, and G. B. Triplett). ASA, Madison, WI.

Oelsligle, D. D., R. Menenses, and R. E. McCollum (1976). Nitrogen response by a corn-cassava intercropped system in the Atlantic coast of Costa Rico. Tropical Soils Res. Program Annual Report 1975, N. C. State Univ., Raleigh, pp. 197-200.

Ofori, C. S. (1973). Shifting Cultivation - Reasons underlying its practice. FAO/SIDA Regional Seminar on Shifting Cultivation and Soil Conservation in Africa. Ibadan.

Ofori, F. (1986). Maize/cowpea intercrop: A case study of the efficiency of cereal/legume intercrop systems. Ph.D. Thesis, Univ. Western Australia.

Ofori, F. and W. R. Stern (1986). Maize/cowpea intercrop system: effect of nitrogen fertilizer on productivity and efficiency. Field Crops Res. 14:247-261. 
Ofori, F. and W. R. Stern (1987). Relative sowing time and density of component crops in maize/cowpea intercrop system. Expl. Agric. 23:41-52.

Ofori, F. and W. R. Stern (1989). Cereal-legume intercropping systems. Adv. Agronomy 41:41-90.

Ofori, F., J. S. Pate, and W. R. Stern (1987). Evaluation of N2 fixation in a maize/cowpea intercrop system using $15 \mathrm{~N}$ methods. Australian Centre Intl. Agric. Res. (ACIAR), pp. 274-275.

Ofuya, T. I. (1991). Observations of insect infestation and damage in cowpea (Vigna unguiculata) intercropped with tomato (Lycopersicon esculentum) in a rain forest area of Nigeria. Expl. Agric. 27:407-412.

Ogbonna, C. K. C. and B. B. Mabbayad (1984). The influence of stylo corn intercrop and the incorporation of stylo herbage as green manure on the yield of corn (Zea mays L.) and on soil properties. Philipp. J. Crop Sci. 9:25-28.

Ogunfowora, D. (1974). An optimization model for evaluating the stability of sole cropping and mixed cropping systems under changing resource and technology levels. Samaru. $11 \mathrm{pp}$.

Ogunfowora, O. and D. W. Norman (1974). An optimization model for evaluating the stability of sole cropping and mixed cropping systems under changing resource and technology levels. Samaru, Nigeria: Inst. Agric. Res. Samaru Res. Bull. 217.

Ogwaro, K. (1983). Intensity levels of stem-borers in maize and sorghum and the effect on yield under different intercropping patterns. Insect Sci. Applica. 4(1/2):33-37.

Ohler, J. H. (1975). Cattle under coconuts intercropping and grazing. J. Agric. Soc. Trinidad Tobago 74(4):352-361.

Ojeifo, I. M. and E. O. Lucas (1987). The growth and development of Corchorus olitorius (L.) grown alone and intercropped with tomato (Lycopersicon esculentum (Mill.)). f. Agric. Sci. 109:39-45.

Okali, C., J. E. Sumberg, and K. C. Reddy (1994). Unpacking a technical package: flexible messages for dynamic situations. Expl. Agric. 30:299-310.

Okeke, J. E. (1984). Cassava productivity in intercropping systems. Proc. Sixth Symp. Intl. Soc. Trop. Root Crops, Intl. Potato Center (CIP), pp. 277-281.

Okeke, J. E. (1996). Effects of spatial arrangement and relative time of planting on intercropped maize and cassava. Trop. Sci. 36:6-10.

Okigbo, B. N. (1973). A preliminary new look at the IITA Farming Systems Program. Mimeo. IITA, Ibadan.

Okigbo, B. N. (1974). Fitting research to farming systems. In Proceedings, $2^{\text {nd }}$ International Seminar on Change in Agriculture, Reading, 11 pp.

Okigbo, B. N. (1974). Maize/melon/cassava intercropping. IITA Annual Report, Ibadan.

Okigbo, B. N. (1975). Erosion hazards and farming systems in West Africa. Soil Conservation and Management Workshop, IITA, Ibadan.

Okigbo, B. N. (1976). Plant technology in today's world and problems of continued widespread adoption in LDCS. IITA, Ibadan.

Okigbo, B. N. (1976). Traditional cropping systems in Africa. IITA, Ibadan.

Okigbo, B. (1979). Evaluation of plant interactions in complex mixtures as a basis for improved cropping systems design. In International Workshop on Intercropping ((ed: R. W. Willey), ICRISAT, pp 155-179.

Okigbo, B. N. (1982). Evaluation of plant interactions and productivity in complex mixtures as a basis for improved cropping systems design. In International Workshop on Intercropping (ed: R. W. Willey and C. Garver). ICRISAT, pp. 155-179.

Okigbo, B. N. (Editor) (1978). Cropping Systems and Related Research in Africa. Assoc. Adv. Agric. Sci. in Africa, (AAASA) Occasional Publ. Series, IITA, Ibadan, Nigeria.

Okigbo, B. N. and D. J. Greenland (1976). Intercropping systems in tropical Africa. In Multiple Cropping (ed: R. I. Papendick et al.) ASA Spec. Publ. 27, Madison, WI, pp.63-101.

Okigbo, B. N. and R. Lal (1982). Residue mulches, intercropping and agri-silviculture potential in tropical Africa. Basic Tech. Ecol. Farm, Birkhauser Verrlag, Basal, Switzerland, pp. 54-69.

Okoli, P. S. O. and G. F. Wilson (1984). Effect of stem cut-back on yield and yield components of intercropped cassava. Proc. Sixth Symp. Intl. Soc. Trop. Root Crops, Intl. Potato Center (CIP), pp. 283-286. 
Okoli, P. S. O. and G. F. Wilson )1986). Response of cassava (Manihot esculenta Crantz) to shade under field conditions. Field Crops Res. 14:349-359.

Okoli, P. S. O., P. L. Drolsom, and J. M. Scholl (1984). Forage production and weed control in a doublecropping program. Agronomy J. 76:363-366.

Oktingati, A., J. A. Maghembe, E. C. M. Fernandes, and G. H. Weaver (1984). Plant species in the Kilimanjaro agroforestry system. Agroforestry Syst. 2:177-186.

Olasantan, F. O. (1985). Effects of intercropping, mulching and staking on growth and yield of tomatoes. Expl. Agric. 21:135-144.

Olasantan, F. O. (1985). Intercropping tomato with cowpea using different planting patterns. Beitr. Trop. Landwirtsch Veterinarmed 23:397-404.

Olasantan, F. O. (1988). The effects on soil temperature and moisture content and crop growth and yield of intercropping maize with melon (Colocynthis vulgaris). Expl. Agric. 24:67-74.

Olasantan, F. O. (1991). Response of tomato and okra to nitrogen fertilizer in sole cropping and intercropping with cowpea. J. Hort. Sci. 66:191-199.

Oliver, L. R. (1979). Influence of soybean (Glycine max) planting date on velvetleaf (Abutilon theophrasti) competition. Weed Sci. 27:183-188.

Oloo, G. W. and K. Ogeda (1990). The incidence of Chilo partellus (Swinh.) (Pyralidae) and the contribution of natural enemies to its mortality under intercropping system in Kenya. Trop. Pest Mgt. 36:244-248.

Olsen, F. J., J. H. Jones, and J. J. Patterson (1981). Sod-seeding forage legumes in a tall fescue swiard. Agronomy J. 73:1032-1036.

Olsen, R. J., R. F. Hensler, O. J. Attoe, et-al. (1970). Fertilizer nitrogen and crop rotation in relation to movement of nitrate nitrogen through soil profiles. Soil Sci. Soc. Amer. Proc. 34:448-452.

Olson, R. A., W. R. Raun, Y. S. Chun, and J. Skopp (1986). Nitrogen management and interseeding effects on irrigated corn and sorghum and on soil strength. Agronomy J. 78:856-862.

Omolo, E. O., B. Nyambo, C. O. J. Simbi, and P. Ollimo (1993). The role of host plant resistance and intercropping in integrated pest management (IPM) with specific reference to the Oyugis project. Intl. J. Pest Mgt. 39:265-272.

Onwueme, I. C. (1984). The place of the edible aroids in tropical farming systems. In Edible Aroids (ed: S. Chandra), pp. 136-139.

Onyeagba, R. A., R. P. A. Unamma, and T. Enyinnia (1988). Effects of duration of weed interference and intercropping on incidence and severity of cassava anthracnose disease (CAD) in cassava/yam/maize intercrop. J. Plant Prot. Trop. 5:51-54.

Orkwor, G. C., O. U. Okereke, F. O. C. Ezedinma, et al. (1994). The response of yam (Dioscorea rotundata Poir.) to various periods of weed interference in an intercropping with maize (Zea mays L.), okra (Abelmoschus esculentus L. Moench), and sweet potato (Ipomoea batatas L. Lam). Acta Hort Nov., 380:349-354.

Ormandzhi, K. S. (1986). Production regulations of powered machines for inter-row crops. Izd. 2-e, perer. i dop. Rossel'khozizdat, Moskva, 303 pp..

Ortega, M. P. F. and J. M. C. Campo (1993). Intercropping rye-grass (Lollium multiflorum) on beans: an alternative production system for small farmers in Sonora, Mexico. Annual Rep. Bean Improvement Coop., Colorado State Univ., p. 113.

Ortiz, R. (1995). Plot techmiques for assessment of bunch weight in banana trials under two systems of crop management. Agronomy J. 87:63-69.

Orwick, P. L. and M. M. Schreiber (1979). Interference of redroot pigweed (Amaranthus retroflexus) and robust foxtail (Setaria viridis var. robusta-alba or var. robusta-purpurea) in soybeans (Glycine max). Weed Sci. 27:665-674.

Osiru, D. S. O. (1974). Physiological studies of some annual crop mixtures. Ph.D. Thesis, Makerere Univ., Kampala, Uganda.

Osiru, D. S. O. (1983). Intercropping: a review of the possible advantages. In Frontiers of Research in Agriculture (ed: S.K. Roy), Calcutta, pp. 304-320.

Osiru, D. S. O. and H. C. Ezumah (1994). Genotype evaluation for intercropping systems. Acta Hort. 380:62-71. 
Osiru, D. S. O. and R. W. Willey (1972). Studies on mixtures of dwarf sorghum and beans ( Phaseolus vulgaris) with particular reference to plant population. J. Agric. Sci. 79:531-540.

Osiru, D. S. O. and R. W. Willey (1976). Studies of mixtures of maize and beans with particular emphasis in the time of planting beans. In Intercropping in Semi-Arid Areas (ed: J. H. Monyo, A. D. R. Ker, and H. Campbell). Univ. Dar es Salaam, Morogoro, Tanzania, and IDRC. Ottawa. Canada.

Osman, A. A. and A. H. Rasmy (1976). Promotion of tetranychidae by intercropping of peanuts in citrus groves and results of chemical control measures. Anz Schadlingskd Pflanzenschutz Umweltschutz, 49(4):53-54.

Osman, M. S. (1981). Intercropping of sugar beet with berseem for higher forage production (Egypt). Ain Shams Univ. Fac. Agric., The Faculty, Issue 1671, 13 pp.

Ott, S. L. (1987). An economic and energy analysis of crimson clover as a nitrogen fertilizer substitute in grain sorghum production. In The Role of Legumes in Conservation Tillage Systems (ed: J. F. Power). Soil Conserv. Soc. Amer., Ankeny, Iowa, pp. 150-151.

Ovalles, O. (1983). Potential of intercropping in the southern part of Monagas State (a statistical approximation) (Theoretical crop yielding performance, Venezuela). Bol. Soc. Venez. Cienc. Nat., La Sociedad 38:5-16.

Owens, L. B., W. M. Edwards, R. W. Van-Keuren (1994). Groundwater nitrate levels under fertilized grass and grass-legume pastures. J. Environ. Qual. 23;752-758.

Oyejola, B. A. (1983). Some statistical considerations in the use of land equivalent ratio to assess yield advantages in intercropping. Ph.D. Thesis, Univ. Reading.

Oyejola, B. A. (1990). Confidence intervals for staple and effective LER values. Expl. Agric. 26:213-220.

Oyejola, B. A. and R. Mead (1982). Statistical assessment of different ways of calculating land equivalent ratios. Expl, Agric. 18(2):125-138.

Oyenuga, V. A. (1959). Nigeria's Feeding Stuffs, Their Composition and Nutritive Value, $2^{\text {nd }}$ Edition. Univ. Press, Ibadan.

Oyer, L. J. and J. T. Touchton (1988). Nitrogen fertilizer requirements for corn with no-tillage and cropping systems. Proc. Southern Conserv. Tillage Conf., Mississippi Agric. and For. Res Sta. Spec. Bull. 88-1, pp. 38-40.

Paden, W. K. (1962). Ladine clover - tall fescue association as affected by soil treatment and grass population variables. Agronomy J. 54:190-192.

Paine, L. K. and H. Harrison (1993). The historical roots of living mulch and related practices. HortTech. 3:137-143.

Pal, M., S. L. Pandy, and B. P. Mathur (1973). Cropping patterns in multiple cropping systems. Agric, Mech. Asia 4:31-36.

Palada, M. C. and R. R. Harwood (1974). The relative return of corn-rice intercropping and monoculture to nitrogen application. Paper, $5^{\text {th }}$ Annual Scientific Meeting Crop Sci. Soc., Philippines.

Palaniappan, S., D. S. Rajan, and R. Sudhakara-Rao (1985). Intercropping of compatible crops in pigeonpea (Cajanus cajan L. Huth) under rainfed conditions. Z. Acker Pflanzenbau J. Agron. Crop Sci. 155:30-33.

Palmer, J. H., C. Hood, S. U. Wallace et al. (1993). Soybeans: relay intercropping with wheat. Coop. Ext. Serv., Clemson Univ., Soybean Leaflet, 4 pp.

Pamplona, P. P. and J. S. Imlan (1976). Prospects and problems of intercropping corn with legumes, mung beans, peanuts, soybeans in Southern Mindanao. Philippines. MTT Res. J. 6(1):1-9.

Panchabhavi, K. S. and K. Jai Rao (1978). Note on the effect of mixed cropping of niger on the activities of insect pollinators and seed-filling of sunflower in Karnataka. Indian J. Agric. Sci. 48(4):254255.

Pandey, R. B. and R. C. Pande (1982). Studies on the pure and mixed cropping of cereals, oil seed, and legumes under rainfed conditions. Intercropping, India. JNKVV Res. J. Jawaharlal Nehru Krishi Vishma Vidyalay a. Jabalpur 16(1):57-59.

Pandey, R. K. and J. W. Pendleton (1986). Soybeans as a green manure in a maize intercropping system. Expl. Agric. 22:179-185.

Paner, Jr., V. E. (1975). Multiple cropping research in the Philippines. Proc. Cropping Systems Workshop, IRRI, Los Banos, Laguna, Philippines, pp. 188-202. 
Paniagua, G. C. V. (1977). Identification and stability analysis of traits important to yield of beans in associated culture. Ph.D. Thesis, Michigan State Univ.

Pantelides, D. (1979). On the analysis of intercropping experiments. M.Sc. Thesis, Reading Univ.

Panter, D. M. and F. L. Allen (1989). Simulated selection for superior yielding soybean lines in conventional vs. double-crop nursery environments. Crop Sci. 29:1341-1347.

Panwar, K. S. and J. P. Rathi (1977). Weed control in pure vs. parallel cropping of greengram and blackgram with early maturing pigeonpea. Proc., Weed Sci. Conf., Andhra Pradesh Agric. Univ., Hyderabad, India.

Paoletti, R. (1990). Performance of lucerne-tall fescue associations established with different methods of sowing. Results of a 4-year trial in north Italy. Ann. Ist. Sper. Colt. Foraggere 8: 65-74.

Papastylianou, I. and S. K. A. Danso (1991). Nitrogen fixation and transfer in vetch and vetch-oat mixtures. Soil Biol. Biochem. 23:447-452.

Papendick, R. I., P. A. Sanchez, and G. B. Triplett (1976). Multiple Cropping. ASA Spec. Publ. 27, Madison, WI.

Parashar, K. S. and R. P. Sharwa (1981). Studies on the comparability of companion cropping in autumn planted sugarcane crop under North Indian condition. Proc. Natl. Symp. Crop Manage. pp. 106111.

Pare, T., F. P. Chalifour, J. Bourassa, and H. Antoun (1992). Forage corn dry-matter yields and N uptake as affected by previous legumes and $\mathrm{N}$ fertilizer. Can. J. Plant Sci. 72:699-712.

Parker, M. L. and K. A. Sorensen (1994). Growing pecans in North Carolina. North Carolina Agric. Ext Serv., 81, 11pp.

Parkhurst, A. M. and C. A. Francis (1986). Research methods for multiple cropping. In Multiple Cropping Systems (ed: C. A. Francis), Macmillan, New York, pp. 285-

Parmar, M. T. (1982). Mixed cropping studies in Gujarat State. Banaskantha: Gujarat Agric. Univ.; 99 pp.

Parrish, J. A. D. and F. A. Bazzaz (1976). Underground niche separation in successional plants. Ecology 57:1281-1288.

Parsons, J. L. (1958). Nitrogen fertilization of alfalfa-grass mixtures. Agronomy J. 50:593-594.

Parsons, J. L. and R. R. Davis (1961). Forage production of birdsfoot trefoil-orchardgrass as affected by cutting schedule. Crop Sci. 1:427-429.

Patel, C. S., R. P. Awasthi, R.P. Singh, and R. D. Singh (1985). Crop production technology for NEH region. Indian Farming 35:17-19, 21-23, 25.

Patel, J. S., M. K. Khistaria, V. J. Paida, et al. (1985). Intercropping of pearlmillet and pigeonpea in rainfed conditions. Indian J. Agron. 30:283-286.

Patel, P. K. and L. D. Vavadia (1979). Intercropping groundnut and soybean with cotton. Gujarat Agric. Univ. Res. J. Ahmedabad 4(2):4-7.

Patil, B. P. and M. Pal (1985). Intercropped legumes cut down nitrogen needs. Indian Farming 35:29, 31.

Patil, B. P. and M. Pal (1985). Investigations on growth, energy output, chemical composition and mineral uptake by legumes intercropped with transplanted pearl millet. Indian J. Agron. 30:181186.

Patil, V. P., V. M. Raut, and G. B. Halwankar (1984). Intercropping of soybean with rainfed cotton in Maharashtra. Indian Farming 34:13.

Patra, D. D., M. S. Sachdev, and B. V. Subbiah (1986). ${ }^{15} \mathrm{~N}$ studies on the transfer of legume-fixed nitrogen to associated cereals in intercropping systems. Biol. Fert. Soils 2:165-171.

Patra, D. D., M. S. Sachdev, and B. V. Subbiah (1987). Forms of fertilizer nitrogen residues in soil after intercropping of maize-cowpea. Biol. Fertil. Soil 4:155-161.

Patra, D. D., M. S. Sachdev, and B. V. Subbiah (1989). Residual value of $15 \mathrm{~N}$-labelled fertilizer applied to a maize-cowpea intercropping system. Biol. Fert. Soils 8:183-188.

Patriquin, D. G., D. Baines, J. Lewis, and A. Macdougall (1988). Aphid infestation of fababeans on an organic farm in relation to weeds, intercrops and added nitrogen. Agric. Ecosyst. Environ. 20:279288.

Patterson, D. T. and E. P. Flint (1983). Comparative water relations, photosynthesis, and growth of soybean (Glycine max) and seven associated weeds. Weed Sci. 31:318-323. 
Patterson, D. T., E. P. Flint and J. L. Beyers (1984). Effects of carbon dioxide enrichment on competition between a 4 carbon pathway weed and 3 carbon pathway crop. Weed Sci. 32(1):101-105.

Patterson, H. D. (1953). The analysis of results of a rotation experiment on the use of straw and fertilizers. J. Agric. Sci. (Camb.) 43:77-88.

Patterson, H. D. (1959). The analysis of a non-replicated experiment involving a single four-course rotation of crops. Biometrics 15:30-59.

Patterson, H. D. (1960). An experiment on the results of a rotation experiment on the use of straw and fertilizers. J. Agric. Sci. (Camb.) 54:222-230.

Patterson, H. D. (1964). Theory of cyclic rotation experiments (with discussion). J. Royal Stat. Soc. B 26:1-45.

Patterson, H. D. (1965). The factorial combination of treatments in rotation experiments. J. Agric. Sci. (Camb.) 65:171-182.

Patterson, H. D. and B. I. Lowe (1970). The errors of long-term experiments. J. Agric. Sci. (Camb.) 74:53-60.

Paul, S. and L. N. Harsh (1981). Effect of management practices and intercropping of forage legumes Dolichos lablab, Clitoria ternatea and Atylosia scarabaeoides in Eenchrus setigerus on forage quality. Forage Res. 7(1):55-59.

Pawar, C. S., V. S. Bhatnagar, and D. R. Jadhav (1985). Heliothis species and their larval parasitoids on sole and intercrop safflower in India. Insect Sci. Appl. 6:701-704.

Pawar, H. K. (1982). Studies on the intensity of intercropping of groundnut in sorghum (Sorghum bicolor, Arachis hypogeae, India). J. Maharashtra Agric. Univ. 7:183-184.

Pawar, H. K. (1982). Studies on the intensity of intercropping of groundnut in sorghum. J. Maharashtra Agric. Univ. Pune 7(2):151-153.

Pawar, H. K. and D. B. Naik (1984). Radiation studies in intercropping of gram in sorghum with planting patterns (Beans, India). J. Maharashtra Agric. Univ. 9:226-227.

Pawar, H. K. and N. K. Umrani (1982). Intercropping of cowpea in sorghum under irrigated conditions. J. Maharashtra Agric. Univ. Pune 7(2):151-153.

Pawar, H. K., V. Y. Gaunkar, and N. K. Umrani (1982). Intercropping of cowpea in sorghum under irrigated conditions (Sorghum bicolor, Vigna sinensis, India). J. Maharashtra Agric. Univ. 7:151153.

Pearce, S. C. (1988). A biometrician in Third World agriculture. Biometrics Bulletin 5(2):8-9.

Pearce, R. C. (1989). Utilization of stored soil moisture by double-cropped soybean. M. S. thesis, Univ. Kentucky, Lexington.

Pearce, R. C., L. J. Grabau, J. H. Gore, and H. Lin (1993). Development of double-crop soybean under different soil water regimes. Agronomy J. 85:576-583.

Pearce, S. C. and B. Gilliver (1978). The statistical analysis of data from intercropping experiments. J. Agric. Sci. (Camb.) 91:625-632.

Pearce, S. C. and B. Gilliver (1979). Graphical assessment of intercropping methods. J. Agric. Sci.(Camb.) 93:51-58

Pearce, S. C. and J. Taylor (1948). The changing of treatments in a long-term trial. J. Agric. Sci. (Camb.) 38:402-410.

Pearce, S. C. and R. N. Edmondson (1984). The Consultant's Forum: Experimenting with intercrops. Biometrics 40:231-237.

Pearce, S. C. and R. N. Edmonton (1982). Historical data as a guide to selecting systems for intercropping two species. Expl. Agric. 18: 353-362.

Pearson, C. J. (1992). Field Crop Ecosystems: Ecosystems of the World 18. Elsevier, Amsterdam.

Pedersen, J. F., K. J. Moore, and E. Van Santen (1991). Interpretive analysis for forage yield trial data. Agronomy J. 83:774-776.

Pedersen, J. F., R. Roderiguez-Kabana, and R. A. Shelby (1988). Ryegrass cultivars and endophyte in tall fescue affect nematodes in grass and succeeding soybean. Agronomy J. 80:811-814.

Pederson, G. A. and G. E. Brink (1988). Compatibility of five white clover and five tall fescue cultivars grown in association. Agronomy J. 80:755-758.

Pederson, G. A. and G. E. Brink (1991). Productivity and quality of annual and perennial clover-tall fescue mixtures. Agronomy J. 83:694-699. 
Peeper, T. F. (1984). Chemical and biological control of downy brome (Bromus tectorum) in wheat and alfalfa in North America. Weed Sci. 32(Suppl. 1):18-25.

Pendleton, J. W. (1957). Fall seed alfalfa with winter wheat? Agonomy J. 49:567-568.

Pendleton, J. W., C. D. Bolen, and R. D. Seif (1963). Alternate strips of corn and soybean vs. solid plantings. Agrononomy J. 55:293-295.

Peng, S. Y and W. B. Sze (1967). Preliminary study on chemical weed control in sugarcane intercropped with soybeans and peanuts. Proc., $1^{\text {st }}$ Asian Pacific Weed Control Interchange, Univ. Hawaii, Honolulu. pp. 85-87.

Peng, S. Y. and L. T. Twu (1980). T"ai-wan T'ang Yeh Yen Chiu so Yen Chiu Hui Pao Rep. Taiwan Sugar Res. Inst., The Institute. No. 88. pp. 1-18.

Peng, S. Y. and L. T. Twu (1981). Further studies on chemical weed control for sugarcane intercropping. T'ai-wan T'ang Yeh Yen Chiu so Yen Chiu Hui Pao Rep. Taiwan Sugar Res. Inst., T'ai-wan t'ang yeh yen chiu so. No. 94. pp. 1-9.

Peralta, F. De (1953). Studies on competition between corn and upland rice plants. Arenata J. Agric. $1(1): 18-27$.

Pereira, J. A. and A. S. Khan (1981). Analyse economica de lavouras isoladas e consorciadas com as culturas de algodao, milho e feijao no Estado do Ceara. Cienc Agron. Fortaleza 12(1/2):201-205.

Perfecto, I., B. Horwith, J. Vandermeer, et al. (1986). Effects of plant diversity and density on the emigration rate of two ground beetles, Harpalus pennsylvanicus and Evarthrus sodalis (Coleoptera: Carabidae), in a system of tomatoes and beans. Environ. Entomol. 15:1028-1031.

Perrin, R. M. (1977). Pest management in multiple cropping systems. Agro-Ecosystems 3:98-118.

Perrin, R. M. and M. L. Phillips (1978). Some effects of mixed cropping Brassica. Entomol. Expl. Appl. 24(3):385-393.

Persaud, N., F. G. Calhoun, M. Gandah, et al. (1993). Evaluation of dryland crop management innovations for subsistence farmers of pearl millet (Pennisetum americanum (L.) K. Schum.) in Niger. European J. Agron. 2:39-50.

Pessoa, S. (1984). Effect of spacing of perennial cotton in double rows on cotton $\times$ cowpea $\times$ sorghum intercropping (Brazil). EMBRAPA Cen. Pesqui. Agropecu. Trop. Semiarid, Issue 22, 17 pp.

Peter, G. and A. Runge-Metzger (1994). Monocropping, intercropping or crop rotation? An economic case study from the West African Guinea Savannah with special reference to risk. Agric. Systems 45:123-143.

Peters, L. N., C. O. Qualset, and F. F. Bell (1971). Soybean varieties for double cropping. Tennessee Farm Home-Sci. 78:12-15.

Peters, R. A. (1961). Legume establishment as related to the presence or absence of an oat companion crop. Agonomy J. 53:195-198.

Peterson, A. E. (1955). Establishing alfalfa in wide row corn. Plant Food Rev. 1(3):16-17, 30-31.

Peterson, M. L. and L. E. Bendixen (1961). Plant competition in relationship to nitrogen economy. Agronomy J. 53:45-49.

Peterson, T. A. and G. E. Varvel (1989). Crop yield as affected by rotation and nitrogen rate. I. Soybean. Agronomy J. 81:727-731

Peterson, T. A. and G. E. Varvel (1989). Crop yield as affected by rotation and nitrogen rate. II. Grain sorghum. Agronomy J. 81:731-734.

Peterson, T. A. and G. E. Varvel (1989). Crop yield as affected by rotation and nitrogen rate. III. Corn. Agronomy J. 81:735-738.

Peterson, T. A., D. G. Westfall, and A. D. Halvorson (1992). Economics of dryland rotations for efficient water and nitrogen use. Great Plains Soil Fertility Conf. Proc., Kansas State Univ., Manhattan, pp. 47-53.

Petrie, C. L. and A. E. Hall (1992). Water relations in cowpea and pearl millet under soil water deficits. I. Contrasting leaf water relations. Australian J. Plant Phys. 19:577-589.

Pfeiffer, T. W. (1987). Variety $\times$ cropping sytem interactions in full season and double crop soybean cropping systems. Appl. Agric. Res. 3:141-145. 
Phillips, J. M., A. H. Brown, Jr., W. C. Loe, et al. (1991). Steer performance as influenced by overseeding annual grasses and clover into tall fescue. Proc. Intl. Symp. Acremonium/Grass Interactions, New Orleans, LA, pp. 244-247.

Phillips, W. M. (1964). A new technique of controlling weeds in sorghum in a wheat-sorghum-fallow rotation in the Great Plains. Weed Sci. 12:42-44.

Piening, L. J. and D. Orr (1988). Effects of crop rotation on common root rot of barley. Can. J. Plant Path. 10:61-65.

Pierce, F. J. and C. W. Rice (1988). Crop rotation and its impact on efficiency of water and nitrogen use. In Cropping Strategies for Efficient Use of Water and Nitrogen (ed: W. L. Hargrove). ASA Spec. Publ. 15, ASA, CSSA, and SSSA, Madison WI, pp. 21-42.

Pierce, W. (1976). Polyculture farming in the cities. In Radical Agriculture, pp. 224-256.

Pierson, C. L. (1973). Agronomic aspects of shifting cultivation. FAO/SIDA Regional Seminar on Shifting Cultivation and Soil Conservation in Africa, Ibadan.

Pieters, A. J. (1917). Green manuring: A review of the American experiment station literature. J. Amer. Soc. Agron. 9:62-74.

Pieters, A. J. (1927). Green Manuring-Principles and Practices. John Wiley \& Sons, Inc.,New York.

Pilbeam, C. J. (1996). Variation in harvest index of maize (Zea mays) and common bean (Phaseolus vulgaris) grown in a marginal rainfall area of Kenya. J. Agric. Sci. 126:1-6.

Pilbeam, C. J., M. Wood, and P. G. Mugane (1995). Nitrogen use in maize-grain legume cropping systems in semi- arid Kenya. Biol. Fert. Soils 20:57-62.

Pillai, G. R., K. Varughese. J. Mathew, G. Santhakumari (1987). Intercropping food legumes with cassava in a rice-based farming system. Australian Centre Intl. Agric. Res. (ACIAR), pp. 240-241.

Pillai, P. N. (1974). Intercropping in rubber, bananas, cassava. Farm. Fact. 8(4):29.

Pillay, A. R. (1982). Intercropping of plant sugarcane with tomato in mauritius cultivars. Rev. Agric. Sucr. Ile Maurice 61(3):149-154..

Pillay, A. R. and J. R. Mamet (1978). Intercroping sugarcane with maize. Expl. Agric. 14:161-165.

Pimentel, D (1976). The ecological basis of insect pest, pathogen and weed problems. In Origin of Pest, Parasite, Disease and Weed Problems (ed: J. M. Cherrett and G. R. Sagar). Blackwell Scientific Publ., London, pp. 1-31.

Pimentel, D. (1961). Species diversity and insect population outbreaks. Annals Ento. Soc. Amer. 19:136142.

Pinchinat, A. M., J. Soria, and R. Bazan (1976). Multiple cropping in tropical America. In Multiple Cropping (ed: R. I. Papendick et al.), ASA Spec. Publ. No. 27, ASA, Madison, WI, pp. 51-61.

Pineda, P., J. A. Kipe-Nolt, and E. Rojas (1994). Rhizobium inoculation increases of bean and maize yields in intercrops on farms in the Peruvian Sierra. Expl. Agric. 30:311-318.

Piper, J.K. (1996). Density of Anomoea flavokansiensis on Desmanthus illinoensis in monoculture and polyculture. Entomologia Experimentalis Applicata 81:105-111.

Pitman, W. D., C. K. Piacitelli, G. E. Aiken, and F. E. Barton II (1991). Botanical composition of tropical grass-legume pastures estimated with near-infrared reflectance spectroscopy. Agronomy J. 83: 103107.

Plett, Jr., G. B. and H. N. Lafever (1977). Relay intercropping wheat and soybeans. Res. Circ. Ohio Agric. Res. Dev. Cent. No. 233. 11 pp.

Pogue, D. E. and B. L. Arnold (1979). Corn-soybean silage compared with corn silage for milk production. Mississippi Agric. For. Expt. Sta. Res. Rep.

Portela, M. C. L. da S., B. V. Defelipo, J. M. Braga, and A. C. Ribeiro (1986). Lime requirements for associated production systems of beans (Phaseolus vulgaris L.) and maize (Zea mays L.) on soils in the microregion of Vicosa, Minas Gerais. II. Field trials. Rev. Ceres 33:23-33.

Porter, L. K., R. F. Follett, and A. D. Halvorson (1996). Fertilizer nitrogen recovery in a no-till wheatsorghum-fallow-wheat sequence. Agronomy J. 88:750-757.

Porter, P. M., J. G. Lauer, W. E. Lueschen, et al. (1997). Environment affects the corn and soybean rotation effect. Agronomy J. 89:441-448.

Porter, P. M., R. K. Crookston, J. H. Ford, et al. (1997). Interrupting yield depression in monoculture corn: Comparative effectiveness of grasses and dicots. Agronomy J. 89:247-250. 
Porter, P. M., R. K. Crookston, W. E. Lueschen, et al. (1996). The corn and soybean rotation effect: Importance of crop rotation. In Field Research in Soil Science. Minn. Agric. Expt.Stn. Misc. Publ. 90-1996. St. Paul, Minn.

Porteres, R. (1962). Primary cradles of agriculture in the African continent. In Papers in African Prehistory, 1970 (ed: J.. D. Fage and R. A. Oliver). Cambridge Univ. Press, London.

Portillo, H. E., H. N. Pitre, K. L. Andrews, and D. H. Meckenstock (1994). The influence of weeds on insect-related mortality of intercropped sorghum and maize in southern Honduras. Trop. Agric. 71:208-214.

Porto, M. C. M. and R. F. Souza (1979). Cassava intercropping in Brazil. Ottawa, Intl. Dev. Res. Centre. pp. 25-30.

Posler, G. L., A. W. Lenssen, and G. L. Fine (1993). Forage yield, quality, compatibility, and persistence of warm-season grass-legume mixtures. Agronomy J. 85:554-560.

Potts, M. J. and N. Gunadi (1991). The influence of intercropping with Allium on some insect populations in potato (Solanum tuberosum). Ann. Appl. Biol. 119:207-213.

Poultney, R., J. Riley, and R. Webster (1997). Optimizing plot size and shape for field experiments on terraces. Expl. Agric. 33:51-64.

Power, J. F. (1990). Legumes and crop rotations. In Sustainable Agriculture in Temperate Zones (ed: C. A. Francis et al.) John Wiley \& Sons, Inc. New York, pp. 178-294.

Power, J. F. (1994). The Role of Legumes in Conservation Tillage Systems. Proc. Natl. Conf. (SCS), Univ. Georgia, Athens, GA.

Power, J. F. and F. E. Broadbent (1989). Proper accounting for $\mathrm{N}$ in cropping systems. In Nitrogen Management and Groundwater Protection (ed: R. F. Follett). Elsevier Science Publ. Co., New York, pp. 160-182.

Power, J. F. and V. O. Biederbeck (1991). Role of cover crops in integrated crop production systems. In Cover Crops For Clean Water (ed: W. L. Hargrove). Soil Water Conserv. Soc., Ankeny, Iowa, pp.167-174.

Power, J. F., J. W. Doran, and P. T. Koemer (1991). Hairy vetch as a winter cover crop for dryland corn production. J. Prod. Agric. 4:62-67.

Powers, L. E., R. McSorley, and R. A. Dunn (1993). Effects of mixed cropping on a soil nematode community in Honduras. J. Nematology 25:666-673.

Prabhakar, A. S. and T. K. P. Setty (1973). Economics of intercropping hybrid sorghm and soyabean, India. Agric. Agro-Ind. J. 6(2):17-18.

Prabhakar, B. S., V. Shukla, and K. Srinivas (1985). Nutritional potential of vegetable inter-cropping systems. Indian J. Hort. 42:258-262.

Prabhakar, M. and G. M. Nair (1984). Intercropping in cassava. Indian Farming 34:9-10.

Pradhan, S. (1971). Revolution in pest control. World Sci. News 8:41-47.

Prajapati, R. K., P. K. Khosla, and S. Puri (1995). Some agroforestry models for Chhattisgarh area of Madhya Pradesh, India. New Zealand For. Res. Inst. FRI Bull. 192:292-294.

Prakasa-Rao, E. V. S., M. Singh, and R. S. Ganesha-Rao (1984). Intercropping studies in geranium (Pelargonium graveolens L. Her. ex Ait) (Yields, India). J. Agric. Sci. 102:499-500.

Prasad, J. S., M. S. Panwar, and Y. S. Rao (1987). The influence of intercropping greengram and redgram with rice on the build-up of the root-lesion nematode, Pratylenchus indicus. Biol. Agric. Hort. Int. J. 5:61-69.

Prasad, K., R. C. Gautam, and N. K. Mohta (1985). Effect of planting patterns and weed control methods on growth characters, yield and yield attributes of arhar intercropped with soybean. Indian J. Agron. 30:429-433.

Prasad, K., R. C. Gautam, and N. K. Mohta (1985). Studies on weed control in arhar and soybean as influenced by planting patterns, intercropping and weed control methods. Indian J. Agron. 30:434439.

Prasad, M. V. R. (1975). Suitable plant type of green gram mung beans for intercropping with cenchrus on dry lands. Forage Res. 1(2):151-153.

Prasad, S. and B. D. Patil (1982). Pigeonpea (Cajanus cajan) based forage intercropping systems light relations and growth performance. Z. Acker Pflanzenbau J. Agron. Crop Sci. 151(6):417-429. 
Prasad, S., C. R. Hazra, and B. D. Patil (1982). Pigeonpea (Cajanus cajan) based forage intercropping systems light relations and growth performance (Catch cropping). Z. Acker Pflanzenbau J. Agron. Crop Sci. 151:417-429.

Prawoto, A. (1982). Observations on some problems in intercropping and the possibility of its application in cocoa plantations (Indonesia). Menara Perkebunan, Bogor, 50:49-56.

Prawoto, A. (1982). Tinjauan beberapa masalah dalam tumpangsari dan kemungkinan penerapannya pada pertanaman cokelat. Menara Perkebunan. Bogor. Balai Penelitian Perkebunan 50(2):49-56.

Preece, D. A. (1986). Some general principles of crop rotation experiments. Expl. Agric. 22:187-198.

Preston, S, R., B. R. Taylor, and J. H. Simons (1986). The choice of groundnut (Arachis hypogaea) varieties by smallholders in south-east Tanzania. II. Variety $\times$ spacing and variety $\times$ sowing date interactions. Expl. Agric. 22:279-287.

Prince, P. W. and G. P. Waldbauert (1975). Ecological aspects of insect pest management. In. Introduction to Insect Pest Managewent (ed R. L. Metcalf and W. H. Luckmann). Wiley, New York, pp. 36-73.

Prine, G. M. (1961). Light, a factor to be considered in growing corn. Soil Crop Sci. Soc. Fla. Proc. 21:221-228.

Probst, A. H. (1957). Performance of variety blends in soybeans. Agonomy J. 49:148-150.

Prummel, J. (1982). Fosfaat - en kalibemesting van het tweede groentegewas bij dubbelteelten op akkerbouwbedrijven. Bedrijfsontwikkeling. 13(8):759-761.

Prusty, J. C., M. Pal, and Dayanand (1985). Energy utilization and efficiency study in maize based intercropping systems. Indian J. Agron. 30:440-444.

Pumphrey, F. V. and F. E. Koehler (1958). Forage and root growth of five sweet clover varieties and their influence on two following corn crops. Agronomy J. 50:323-326.

Punzalan, F. L. (1972). Field screening of herbicides for weed control in corn intercropped with peanut. In Weed Science Report, Dept. Agril. Botany, Univ. Philippines, Laguna, pp. 87-90.

Putman, D. H. (1986). Plant competition studies: Intercropping groundnuts and estimation of competitive effects in corn. Ph.D. thesis, Univ. Massachusetts, Amherst.

Putman, D. H. and D. L. Allan (1992). Mechanism for overyielding in a sunflower-mustard intercrop. Agronomy J. 84:188-195.

Putnam, A. R. and W. O. Duke (1974). Biological suppression of weeds: Evidence for allelopathy in accessions of cucumber. Science 185:370-372.

Putnam, A. R., J. DeFrank, and J. P. Barnes (1983). Exploitation of allelopathy for weed control in annual and perennial cropping systems. J. Chem. Ecol. 9:1001-1010.

Putnam, D. H., S. J. Herbert, and A. Vargas (1986). Intercropped corn-soyabean density studies. II. Yield composition and protein. Expl. Agric. 22:373-381.

Quarshie, H. M. (1979). Yield of local sorghum (Sorghum vulgare) cultivars and their mixtures in northern Ghana. Trop. Agric. 56:125-133.

Queenel, M. (1981). Exploitation par affermage d'un vaste domaine de polyculture en Bourgogne en 1775. Acad. Agric. Fr C R Seances 67(17):1498-1502.

Queiroz, M. A. de and N. W. Galwey (1987). The effects of sorghum and cowpea genotype and sorghum sowing density in an intercrop system. Expl. Agric. 23:387-394.

Rabb, J. L. and D. R. Melville (1984). Double cropping soybeans and wheat in northwestern Loiusiana. J. Soil Water Conserv. 39:77-78.

Rachie, K. O. (1983). Intercropping tree legumes with annual crops. In Plant Research and Agroforestry: Proc. (ed: P. A. Huxley), pp. 103-116.

Radke, J. K. and R. T. Hagstrom (1976). Strip intercropping for wind protection. In Multiple Cropping (ed: M. Stelly). ASA Spec Publ. 27, ASA, CSSA, and SSSA, Madison, WI, pp. 201-222.

Rafey, A. (1981). Mixed cropping of rabi pulses in dryland region of Chotanagpur, India. Train. Cum. Discus. Semin. Rabi Pulse, Ranchi, India, pp. 45-48.

Raghavarao, D. and W. T. Federer (1979). Block total response as an alternative to the randomized response method in surveys. J. Royal Statistical Soc., Ser. B, 41:40-45.

Ragnar, E., R. C. Wakefield, and W. M. Sullivan (1985). Effect of spray/planting intervals and various grass sods on no-till establishment of alfalfa. Agronomy J. 77:5-8. 
Raheja, A. K. (1977). Pest and disease relationships within various crop mixtures. Res. Program 1977-78. Inst. Agric. Res., Samaru, Nigeria.

Raheja, P. C. (1973). Mixed cropping. Indian Council Agric. Res., ICAR Tech. Bul. No. 42.40 pp.

Rahman, A. and A. Quasem (1982). Performance of compatibility of legumes and nonlegumes with maize intercropping. Bangladesh J. Agric. 7(2):14-19.

Rahman, A., K. P. Sinha, Y. P. Singh, et al. (1982). Effect of intercropping pulses, oilseeds and tuber crops in maize on yield and net return (Profitableness, Ranchi Agricultural College Farm, India). Indian J. Agron. 27:1-6.

Rahman, A., S. K. Roy, and A. K. Bhagat (1982). Effect of intercropping pulses, oilseeds and tuber crops in maize on yield and net return profitableness. Indian J. Agron. 27:1-6.

Rai, P. (1985). Forage production of buffel grass as influenced by intercropping with legumes. Ann. Arid Zone 24:341-345.

Rai, P. (1986). Effect of spacing and phosphorus rates on forage production in Dichanthium annulatum and Sesbania sesban intercropping system. Ann. Arid Zone 25:283-289.

Raimbault, B. A. and T. J. Vyn (1991). Crop rotation and tillage effects on corn growth and soil structural stability. Agronomy J. 83:979-985.

Raimbault, B. A., T. J. Vyn, and M. Tollenaar (1990). Corn response to rye cover crop management and spring tillage systems. Agronomy J. 82:1088-1093.

Raimbault, B. A., T. J. Vyn, and M. Tollenaar (1991). Corn response to rye cover crop, tillage methods, and planter options. Agronomy J. 83:287-290.

Raj, S. P. and N. Sukumaran (1980). Growth of stunted mrigal in polyculture system pond fish culture.

- Madras Agric. J. Coimbatore 67(10):671-672.

Rajah, C and R. Elangovan (1978). Intercropping in rainfed groundnut (Arches hypogaea I.). Agric. Agroind. J. Bombay 11( 10):24-26.

Rajaram, S. and M. Subbarayalu (1979). Mixed cropping in sugarcane. Madras Agric. J. Coimbatore 66(4):267-268.

Rajat De, R. S. Gupta, S. P. Singh, et al. (1978). Interplanting maize, sorghum and pearlmillet with short duration grain legumes. Indian J. Agric. Sci. 48(3):132-137.

Rajbhandari, N. K. (1984). The effect of age of two leguminous green manure crops on transplanted rice. M. S. Thesis, Univ. Philippines at Los Banos, College. Laguna, Philippines.

Rajeswara Rao, B. R. and M. N. Sadaphal (1983). Intercropping cotton with green gram and cowpeas and its residual effect on succeeding wheat crop. Z. Acker Pflanzenbau J. Agron. Crop Sci. 152(3):199207 .

Rajeswara Rao, B. R. and S. P. Singh (1982). Effect of NPK nitrogen-phosphorus-potassium fertilization, time on $\mathrm{N}$ nitrogen application and intercropping with peas and beans on the yields of ergot (Claviceps purpurea) and rye grain alkaloid production. Z. Acker Pflanzenbau J. Agron. Crop Sci. 151(5): 354-359.

Rajeswara Rao, B. R. and S. P. Singh (1983). Spacing and intercropping trials in rye ergot. Indian J. Pharm. Sci. 45:17-18.

Rajput, M. S., K. C. Srivastava, and V. Shukla (1989). Intercropping in young mango orchard. Acta Hort. 231:312-315.

Rajput, M. S., K. C. Srivastava, O. P. Joshi, and P. P. Biswas (1986). Effect of interplanting fruit crops on mangro. Indian J. Hort. 43:216-220.

Rakhmadiono, S., Nurheru, and Marlijunadi (1982). Intercropping ginger among palawija (Zingiber officinale, corn, peanut, small green pea and soybean). Pemberitaan Lembaga Penelitian Tanaman Ind. 8:16-20.

Ram, S., M. P. Gupta, and B. D. Patil (1989). Pest management in fodder cowpea (Vigna unguiculata L. Walp) through mixed-and inter-cropping in India. Trop. Pest Mgt. 35:345-347.

Ramadoss, G. and V. Thirumurugan (1983). Influence of planting systems and different intercrops on yield and economics of long duration redgram (Cajanus cajan (L.). Kilsp.). Madras Agric. J. 70:578-580.

Ramakrishna, A. and C. K. Ong (1994). Productivity and light interception in upland rice-legume intercropping systems. Trop. Agric. 71:5-11. 
Ramakrishna, A., C. K. Ong, and S. L. N. Reddy (1992). Canopy duration and structure of pigeonpea intercropped with upland rice. Expl. Agric. 28:295-307.

Ramakrishnan Nayar, T. V. (1976). Intercropping in young robusta coffee. Indian Cof. 49(2/3):70-74.

Ramalho, M. A. P., A. C. de Oliveira, and J. C. Garcia (1983). Recomendacoes para o planejamento e anilse de experimentos com as culturas de milho e feijao consordiadas. EMBRAPA/CNPAF Docummentos 2.

Ramalho, M. A. P., E. O. Finch, and A. F. da Silva (1982). Mecanizacao do plantio simultaneo de milho e feigao consorciados. Tech. Circular No. 07, EMBRAPA Natl. Center Res. for Corn and Sorghum, Sete Lagoas, M. G., Brazil.

Ramanujam, S. (1981). Role of elite varieties in increasing pulse production. Grain Legume. Bombay, India, pp 34-49.

Ramdoss, G. A. and A. Chamy (1980). Intercropping studies in redgram (Cajanas cajan) pigeon pea. Madras Agric. J. Coimbatore 67(7):464-466.

Ramert, B. (1993). Mulching with grass and bark and intercropping with Medicago litoralis against carrot fly (Psila rosae (F.)). Biol. Agric. Hort Intl. J. 9:125-135.

Ramert, B. and B. Ekbom (1996). Intercropping as a management strategy against carrot rust fly (Diptera: Psilidae): a test of enemies and resource concentration hypotheses. Environ. Entomology 25:10921100 .

Ramos, M. M. (1976). Internationa] Bibliography on Cropping Systems, 1973-74. IRRI, Manila, Philippines, $300 \mathrm{pp}$.

Ramsel, R. E. and G. A. Wicks (1988). Use of winter wheat (Triticum aestivum) cultivars and herbicides in aiding weed control in an ecofallow corn (Zea mays) rotation. Weed Sci. 36:394-398.

Ranasinghe, O. M. and G. J. Mayhead (1990). The effect of intercropping Populus 'RAP' with beans. For. J. Inst. Chart. For. 63:271-277.

Randhawa, G. S. and R. K. Mahey (1988). Advances in the agronomy and production of turmeric in India. Herbs Spices Med. Plants Recent Adv. Bot. Hort. Pharmacol. 3:71-101.

Randhawa, K. S. (1976). Intercropping in sugarcane pays. Indian Farmer 26(2):7-9.

Ranells, N. N. and M. G. Wagger (1993). Crimson clover mangement to enhance reseeding and no-till corn grain production. Agronomy J. 85:62-67.

Ranells, N. N. and M. G. Wagger (1996). Nitrogen release from grass and legume cover crop monocultures and bicultures. Agronomy J. 88:777-782.

Ranganathan, R. (1992). Production possibility frontiers and estimation of competition effects: the use of a priori information on biological processes in intercropping. Expl. Agric. 28:351-367.

Ranganathan, R., M. Fafchamps, and T. S. Walker (1991). Evaluating biological productivity in intercropping systems with production possibility curves. Agric. Syst. 36:137-157.

Rankine, E. B. (1973). Comparative performance: Large scale production vs. small scale production of yams and sweet potatoes in the Caribbean. $3^{\text {rd }}$ Intl. Symp. Tropical Root Crops, Ibadan, Nigeria.

Rao, B. R. R. and R. Prasad (1984). Intergenotypic competition in mixed stands of spring wheat genotypes. Euphytica 33:241-247.

Rao, H. G. P., B. S. Rana, and P. P. Tarhalkar (1979). Stability, productivity and profitability of some intercropping systems in the dryland agriculture. Proc. Intl. Workshop on Intercropping, ICRISAT, Hyderabad, India, pp. 292-298.

Rao, J. V., K. Srinivas, and T. R. Subramanian (1983). Intercropping of legume vegetables with cereals in drylands yields, Karnataka, India. Indian J. Agric. Sci. 53(10):889-892.

Rao, L. J. and B. N. Mittra (1990). Evaluation of groundnut (Arachis hypogaea) genotypes for intercropping with two types of pigeon pea (Cajanus cajan). J. Agric. Sci. 115:337-342.

Rao, L. J. and B. N. Mittra (1994). Planting pattern of two pigeonpea (Cajanus cajan) cultivars when intercropped with groundnut (Arachis hypogaea). J. Agric. Sci. 122:415-421.

Rao, M. H. (1980). Intercropping in cotton with mungbean, cowpea. Cotton Dev. 12(1/2):33-34.

Rao, M. M. and J. E. Edmunds (1984). Intercropping of banana with food crops: cowpeas, maize and sweet potato. Trop. Agric. 61(1):9-11, 77.

Rao, M. M., H. Murray, and J. E. Edmunds (1985). Testing the performance of banana cropping systems on farmers' holdings in the Windward Islands. Proc. Caribb. Food Crop Soc. Annu. Meet., Bridgetown, Barbados, pp. 245-248, 318, 329. 
Rao, M. R. (1986). Cereals in multiple cropping. In Multiple Cropping Systems (ed: C. A. Francis), Macmillan Pub. Co., New York, pp. 96-132.

Rao, M. R. and R. W. Willey (1978). Current status of intercropping research and some suggested experimental approaches. Paper, $2^{\text {nd }}$ INPUTS Review Meeting, East-West Center, Honululu, Hawaii.

Rao, M. R. and R. W. Willey (1979). Sorghum in rainfed intercropping systems. Paper, Golden Jubilee Symp., Res. Sta., Parbhani, India.

Rao, M. R. and R. W. Willey (1980). Evaluation of yield stability in intercropping: studies on sorghum/pigeonpea. Expl. Agric. 16:105-112.

Rao, M. R. and R. W. Willey (1980). Preliminary studies of intercropping combinations based on pigeonpea or sorghum. Expl. Agric. 16:29-40.

Rao, M. R. and R. W. Willey (1983). Effects of genotype in cereal pigeonpea (Cajanus cajan) intercropping on the alfisols of the semiarid tropics of India. Expl. Agric. 19:67-78.

Rao, M. R. and R. W. Willey (1983). Effects of pigeonpea plant populations and row arrangement in sorghum pigeonpea intercropping. Field Crops Res. 7(3):203-212.

Rao, M. R. and S. V. R. Shetty (1977). Some biological aspects of intercropping systems on crop weed balance. Proc. Weed Sci. Conf., India.

Rao, M. R. N. (1982). Red oil palm and intercropping. Indian Coconut J. 12:9-11.

Rao, M. R., C. K. Ong, P. Pathak, and M. M. Sharma (1991). Productivity of annual cropping systems on a shallow alfisol in semiarid India. Agrofor. Syst. 15:51-63.

Rao, M. R., S. Ahmed, H. P. M. Gunasena, and A. P. Alcantara (1979). Multi-locational evaluation of productivity and stability of some cereal-legume intercropping systems: A review of inputs trial III. Proc. Final Inputs Review Meeting, East-West Res. Syst. Inst., Honolulu, HI.

Rao, M. R., T. J. Rega, and R. W. Willey (1987). Response of cereals to nitrogen in sole cropping and intercropping with different legumes. Plant Soil 101:167-177.

Rao, M. V., K. P. Jha, B. T. S. Moorthy, and B. K. Mandal (1982). Intercropping green gram Vigna radiata and groundnut Arachis hypogaea with rice Oryza sativa and finger millet Eleusine coracana in the rainy season and the feasibility of a second crop in winter on rainfed uplands of coastal Orissa, India. Indian J. Agric. Sci. 52(10):657-664.

Rao, P. N. and D. S. Murthy (1965). Investigations into mixed cropping in mungari cotton tract of Andhra Pradesh. Indian Cotton J. 19:181-190.

Rao, P. N. and S. V. R. Shetty (1976). Some biological aspects of intercropping systems on crop-weed balance. Indian J. Weed Sci. 8:32-43..

Rao, P., H. C. Sharma, and D. R. Dehiya (1982). Constraints, opportunities and achievements in the production of pulses in Haryana. In Pulse Production, Constraints and Opportunities: Proc. Symp. on Increasing Pulse Production in India - (ed: H.C. Srivastava. et al.), New Delhi, pp. 73-78.

Rao, V. R. (1985). Maximising safflower production: constraints and opportunities. In Oilseed Production: Constraints and Opportunities (ed: H. C. Srivastava et al.). pp. 73-87.

Rastogi, B. K. and J. Venkateswarlu (1985). Cost dimensions of the strategies to exploit potential of rainfed areas. Proc. FAI Seminar 1984 on Productivity, Cost Reduction and Subsidy in Fertiliser Industry (ed: S.P. Gupta. et al.), New Delhi, pp. AGS II.1.1-II.1.28.

Rathi, K. S. (1983). Allelopathic association of Rabi legumes on sugarcane and potato. Legume Res., Karnal, 6:45-48.

Rathi, K. S. and R. A. Singh (1979). Companion cropping with autumn planted sugarcane: a critical review. II. Intercropping of potato with autumn planted sugarcane. Indian Sugar Crops J. 6(4):7175.

Rathi, K. S. and R. A. Singh (1979). Companion cropping with autumn planted sugarcane: a critical review. III. Intercropping of mustard with autumn planted sugarcane. Indian Sugar Crops J. 6(4):76-82.

Rathi, K. S. and R. A. Singh (1980). Companion cropping with autumn planted sugarcane, a citical review: IV. Intercropping of pea with autumn planted sugarcane. Indian Sugar Crops J. 7(1):16-21.

Rathi, K. S. and R. A. Singh (1980). Companion cropping with autumn planted sugarcane, a critical review: VI. Intercropping of sugarbeet with autumn planted sugarcane. Indian Sugar Crops J. $7(2): 48-52$. 
Rathl, K. S. and R. A. Singh (1980). Companion cropping with autumn planted sugarcane, a critical review: V. Intercropping of gram chickpeas with autumn planted sugarcane. Indian Sugar Crops J. 7(1):22-26.

Rathmann, D. P. and S. D. Miller (1981). Wild oat (Avena fatua) competition in soybean (Glycine max). Weed Sci. 29:410-414.

Rathore, S. S. (1981). Intercropping studies in sorghum under dryland agriculture to meet weather aberrations, India. Proc. Natl. Symp. Crop Manage, pp. 73-76.

Rathore, S. S. and H. G. Singh (1980). Stand geometry of maize and its intercropping with pulses under dryland agriculture. Indian J. Agron. 25(3):319-322.

Ravichandran, P. K. and S. Palaniappan (1979). Effect of intercropping on dry matter production and nutrient uptake in sorghum (CSH. 5) under rainfed conditions. Madras Agric. J. Coimbatore 19(4):222-229.

Rawlings, J. O. (1974). Analysis of diallel-type competition studies. Crop Sci. 14:515-518.

Razzaque, M. A., M. A. Mannan, S. A., Imam, and A. Ali (1978). Potential of some winter crops for intercropping with sugarcane. Indian J. Agric. Sci. 48(6):324-327.

Reames, A. (1985). Vegetable intercrop for jojoba. Jojoba: Proc. Sixth Intl. Conf. Jojoba and Its Uses, Ben-Gurion Univ. Negev, pp. 133-145.

Reddy, G. J. and M. R. Reddi (1981). Studies on intercropping in maize under varied row spacings. Indian J. Agron. 26(3):360-362.

Reddy, G. P., C. S. Rao, and P. R. Reddy (1965). Mixed cropping in castor. Indian Oilseeds J. 9:310-316.

Reddy, G. R. S., K. Ramaseshaiah, and Y. Y. Rao (1984). Studies on intercropping in Rabi pigeonpea. Andhra Agric. J. 31:77-78.

Reddy, K. A. and M. D. Reddy (1980). Effects of intercropping on yield and returns in corn and sorghum. Expl. Agric. 16(2):179-184.

Reddy, K. C., J. Van-der-Ploeg, and I. Maga (1990). Genotype effects in millet/cowpea intercropping in the semi-arid tropics of Niger. Expl. Agric. 26:387-396.

Reddy, K. C., P. L. Visser, M. C. Klaij, and C. Renard (1994). The effects of sole and traditional intercropping of millet and cowpea on soil and crop productivity. Expl. Agric. 30:83-88.

Reddy, M. N. and B. N. Chatterjee (1973). A note on mixed cropping of soybean (Glycine max L. Herr.) with sorghum (Sorghum vulgare Pers.). Indian J. Agron. 18(2): 238-239.

Reddy, M. N. and B. N. Chatterjee (1973). Intercropping of soybean with rice. Indian J. Agron. 18(4):464-472.

Reddy, M. N. and B. N. Chatterjee (1974). Mixed cropping of soybean with rice, maize and sorghum gives more yield than the pure crops. Agric. Agroind. J. 7(4):28-30.

Reddy, M. N. and C. K. R. Chetty (1984). Stable land equivalent ratio for assessing yield advantage from intercropping. Expl. Agric. 20:171-177.

Reddy, M. N. and C. K. R. Chetty (1984). Staple Land Equivalent Ratio for assessing yield advantage from intercropping (Mathematical and statistical methods). Expl. Agric. 20:171-177.

Reddy, M. S. and R. W. Willey (1982). The relative importance of above- and below-ground resource use in determining yield advantages in pearl millet/groundnut intercropping. In Intercropping: Proc. Symp. on Intercropping in Semi-Arid Areas, 2nd, Morogoro, Tanzania. Intl.Development Center, Ottawa, ON.

Reddy, M. S. and R. W. Willey (1985). Evaluation of alternate cropping systems for Alfisols of the Indian semi-arid tropics. Expl. Agric. 21:271-280.

Reddy, R. P., P. P. Tarhaklar, and N. G. P. Rao (1977). Improved pigeonpea varieties for mono- and intercropping. Indian Farmer 27(9):3-5, 35.

Reddy, S. N., A. V. Reddy, M. S. Raju, and B. B. Reddy (1985). Studies on zinc needs of intercropped maize and groundnut. Andhra Agric. J. 32:234-237.

Reddy, S. N., E. V. R. Reddy, and V. M. Reddy (1989). Row arrangement in groundnut/pigeonpea intercropping. Trop. Agric. 66:309-312.

Reddy, S. V., S. N. Reddy, and M. S. Raju (1985). Intercropping studies in cotton under rainfed conditions. Andhra Agric. J. 32:24-26.

Redhead, J. F., J. A. Maghembe, and B. J. Ndunguru (1983). The intercropping of grain legumes in agroforestry systems. In Plant Research and Agroforestry: Proc. (ed: P. A. Huxley), pp. 117-124. 
Rees, D. J. (1986). Crop growth, development and yield in semi-arid conditions in Botswana. II. The effects of intercropping Sorghum bicolor with Vigna unguiculata. Expl. Agric. 22:169-177.

Rees, D. J. (1986). The effects of population density and intercropping with cowpea on the water use and growth of sorghum in semi-arid conditions in Botswana. Agric. Forest Meteorol. 37:293-308.

Reese, A. A., S. Ginting, P. Ketaren, et al. (1987). Integrated small ruminant and tree-cropping systems in Indonesia. In Small Ruminant Production Systems in South and Southeast Asia (ed: C. Devendra). Proc. Workshop, Bogor, Indonesia, pp. 257-268.

Reestman, A. J. (1946). De beteekinis van de Virusziekten van de aardappel naar aanleidung van proeven met gekeurden ongekeurd poot goed. Tijdschrift over Plantenziekten 52:97-118.

Reeves, C. W. amd C. W. Wood (1994). A sustainable winter-legume conservationn tillage system for maize; Effects on soil quality. In Proc. Int. Soil Tillage Res. Org.(ISTRO), 13th (ed: H. E. Jensen et al.). Aalborg, Denmark, pp. 1011-1016.

Reeves, D. W. (1994). Cover crops and rotations. In Crop Residue Management Advances in Soil Science (ed: J. L. Hatfield and B. A. Stewart). Lewis Publ., CRC Press, Boca Raton, FL, pp. 125-172.

Regnier, E. (1987). Aspects of velvetleaf (Abutilon theophrasti Medik.), jimsonweed (Datura stramonium L.) and common cocklebur (Xanthium strumarium L.) interference with soybeans. Ph.D. Thesis, Univ. Illinois, Urbana-Champaign.

Rego Neto, J. and J. H. Alves (1982). Efeitos do sistema de cultivo sobre a producao e seus componentes emfeijao-de-corda, Vigna sinensis L. Savi. Cienc. Agron. Fortaleza: Centro de Ciencias Agrarias da Univ. Federal do Ceara 13(1/2):35-41.

Rego, N. J., J. B. Paiva, J. H. R. dos Santos, and J. H. Alves (1982). Effects of the planting system on yield and its components in cowpeas (Vigna sinensis (L.) Savi) (Intercropping, varieties, Brazil). CiencAgron., Fortaleza, 13:35-41.

Rehm, G. W., J. T. Nichols, R. C. Sorensen, and W. J. Moline (1975). Yield and botanical composition of an irrigated grass-legume pasture as affected by fertilization. Agronomy J. 67:64-68.

Reid, D. (1961). Factors influencing the role of clovers in grass-clover leys fertilized with nitrogen at different rates. II. The effects of the variety of white clover on the yields of total herbage and of clover. J. Agric. Sci. 56:155-160.

Reid, D. (1967). Studies on the cutting managment of grass-clover swards. V. The effect of changes in the closeness of cutting at different times in the season on the yield and quality of herbage from a perennial ryegrass-white clover sward. J. Agric. Sci. 68:249-254.

Reining, P. (1970). Social factors and food production in an east African peasant society: The Haya. In African Food Production Systems: Cases and Theory (ed: P. F. M. McLoughlin). The John Hopkins Press, Baltimore..

Rejmenek, M., G. R. Robinson, and E. Rejmankova (1989). Weed-crop competition: Experimental designs and models for data analysis. Weed Sci. 37:276-284.

Relwani, L. L. and B. P. Patil (1983). Intercropping of kubabul cultivars with different grasses. Leucaena Leucocephala India, Ministry Agric., pp. 205-206.

Relwani, L. L. and D. Y. Khandale (1982). Intercropping of four Leucaena cultivars with three grasses, Pennisetum purpureum $x$ Pennisetum americanum, pearl millet, Panicum maximum, guineagrass, Chloris gayana, rhodesgrass. Leucaena Res. Rep., Taipei, Taiwan 3:41.

Relwani, L. L., R. S. Sutar, S. S. Deshmukh, et al.(1983). Intercropping of kubabul with guineagrass at different spacings (Leucaena leucocephala, Panicum maximum, yields). In Leucaena Leucocephala in India, Proc. Natl. Sem., Urulikranchan, (ed: R. N. Kaul, M.G. Gogate, and N. K. Mathur), pp. 207.

Relwani, L. L., R. V. Nakat, and B. P. Patil (1983). Intercropping of kubabul cultivars with different grasses (Leucaena leucocephala). In Leucaena Leucocephala in India, Proc. Natl. Sem., Urulikranchan, (ed: R. N. Kaul, M.G. Gogate, and N. K. Mathur), pp. 205-206.

Relwani, L. L., R. V. Nakat, and D. Y. Khandale (1982). Intercropping of four Leucaena cultivars with three grasses (Pennisetum purpureum $\times$ Pennisetum americanum, pearlmillet, Panicum maximum, guineagrass, Chloris gayana, rhodesgrass). Leucaena Res. Rep. 3:41.

Remison, S. U. (1978). Neighbor effects between maize and cowpea at various levels of nitrogen and phosphorus. Expl. Agric. 14(3):205-212. 
Remison, S. U. (1980). Interaction between maize and cowpea at various frequencies. Intercropping. J. Agric. Sci. 94(3):617-621.

Remison, S. U. and R. W. Snaydon (1980). Effects of defoliation and fertilizers on root competition between Dactylis glomerata and Lolium perenne. Grass For. Sci. 35:81-93.

Rerkasem, K., B. Rerkasem, and S. Wongwatana (1987). Nitrogen nutrition in legume/non-legume intercrops. Australian Centre Intl. Agric. Res. (ACIAR), p. 278.

Reynolds, M. P., K. D. Sayre, and H. E. Vivar (1994). Intercropping wheat and barley with N-fixing legume species: a method for improving ground cover, $\mathrm{N}$-use efficiency and productivity in low input systems. J. Agric. Sci. 123:173-183.

Reynolds, R. (1986). 6 × 6=\$18/a more. New Farm. 8:12-14.

Rezende, G. D. S. and M. A. P. Ramalho (1994). Competitive ability of maize and common bean (Phaseolus vulgaris) cultivars intercropped in different environments. J. Agric. Sci. 123:185-190.

Rhoden, E. G., C. K. Bonsi, and V. A. Khan (1991). The effect of intercropping sweetpotato and okra on yield efficiency. Wash. Carver Agric. Expt. Sta., Tuskegee Univ., pp. 27.

Rhodes, I. (1968). The growth and development of some grass species under competitive stress. I. Competition between seedlings, and between seedlings and established plants. J. Br. Grassl. Soc. 23:129-136.

Rhodes, I. (1969). The yield, canopy structure and light interception of two ryegrass varieties in mixed culture and monoculture. J. Br. Grassl. Soc. 24:123-127.

Rhodes, I. (1970). The production of contrasting genotypes of perennial rye-grass (Lolium perenne L.) in monocultures and mixed cultures of varying complexity. J. British Grassland Soc. 25:285-288.

Rhodes, I. (1981). The physiological basis of variation in the yield of grass/clover mixtures. In Plant Physiology and Herbage Production (ed: C. E. Wright). Occas. Symp. no. 13, Br. Grassl. Soc., Hurley. UK. pp. 149-161.

Rice, E. L. (1974). Allelopathy. Academic Press, New York.

Ridgman, W. J. and R. B. Wedgewood (1987). Some residual effects of crop rotation on light land J. Agric. Sci. (Camb.) 108:189-193.

Riley, J. (1984). A general form of 'land equivalent ratio'. Expl. Agric. 20:19-29.

Riley, J. (1985). Examination of the staple and effective land equivalent ratios. Expl. Agric. 21:369-376.

Riley, J. and C. J. Alexander (1997). Statistical literature for participatory on-farm research. Expl. Agric. 33:73-82..

Rimmington, G. M. (1984). A model of the effects of interspecies competition for light on dry-matter production. Aust. J. Plant Physiol. 11:277-286.

Risch, S. (1980). The population dynamics of several herbivorous beetles in a tropical agroecosystem: The effect of intercropplng corn, beans and squash in Costa Rica. J. Appl. Ecol. 17(3):593-611.

Risch, S. J. (1983). Intercropping as cultural pest control: Prospects and limitations. Environ. Manage. 7:9-14.

Risch, S. J. and D. Andow (1982). Foraging by a predaceous beetle, Coleomegilla maculata (Coleoptera: Cocinellidae) in a polyculture: effects of plant density and diversity. Environ. Entomol. 11(4):949950

Risch, S. J. and M. K. Hansen (1982). Plant growth flowering phenologies and yields of corn, beans and squash grown in pure stands and mixture in Costa Rica. J. Appl. Ecol. 19(3):901-916.

Risser, P. G. (1969). Competitive relationships among herbaceous grassland plants. Bot. Rev. 35:251.

Roberts, C. A., K. J. Moore, and K. D. Johnson (1989). Forage quality and yield of wheat-vetch at different stages of maturity and vetch seeding rates. Agronomy J. 81:57-60.

Roberts, G. (1937). Legumes in cropping systems. Kentucky Agric. Expt. Sta. Bull. 374.

Roberts, J. L. and F. R. Olson (1942). Interrelationships of legumes and grasses grown in association. J. Amer. Soc. Agron. 34:695-701.

Roberts-Nkrumah, L. B., T. U. Ferguson, and L. A. Wilson (1995). Performance of sweet potato cultivars intercropped with maize. 2. Total dry matter production and tuber yield responses to staggered maize planting dates. Trop. Agric. 72:210-215.

Roberts-Nkrumah, L. B., T. U. Ferguson, and L. A. Wilson (1995). Performance of sweet potato cultivars intercropped with maize. 1. Total dry matter production and tuber yield responses of two maize populations. Trop. Agric. 72:202-209. 
Robertson, G. W. (1974). Wheat yields for 50 years at Swift Current, Saskatchewan in relation to weather. Can. J. Plant Sci. 54:278-281.

Robertson, J. K. (1941). Mixed or multiple cropping in native agricultural practice. E. Africa Agric. For. J. 6:228.

Robinson, B. H. (1974). Competitive position of soybeans in farming systems. Bull. Tenn. Valley Auth. Natl. Fert. Dev. Cent. 69:155-168.

Robinson, R. G. (1949). Annual weeds, their viable seed population in the soil, and their effect on the yields of oats, wheat, and flax. Agronomy J. 41:513-518.

Robinson, R. G. (1960). Oat-pea and oat-vetch mixtures for forage and seed. Agronomy J. 52:546-549.

Robinson, R. G. (1966). Sunflower-soybean and grain sorghum-corn rotation versus monoculture. Agronomy J. 58:475-477.

Robinson, R. G. (1984). Sunflower for strip, row, and relay intercropping. Agronomy J. 76:43-47.

Robinson, R. G. (1984). Sunflower for strip, row, and relay intercropping Helianthus annuus, Zea mays, Glycine max, Brassica hirta, Phaseolus vulgaris, Secale cereale . Agronomy J. 76:43-47.

Robinson, R. G. (1985). Tillage for sunflower control and for annual canarygrass and fieldbean production. Agronomy J. 77:612-616.

Robinson, R. G. and R. J. Dunham (1954). Companion crops for weed control in soybeans. Agronomy J. 54:278-281.

Roda, A. L., D. A. Landis, M. L. Coggins, et al. (1996). Forage grasses decrease alfalfa weevil (Coleoptera: Curculionidae) damage and larval numbers in alfalfa-grass intercrops. J. Econ. Entomology. 89:743-750.

Roder, W. (1987). Sorghum-soybean rotation and fertilizer effect on selected soil properties and crop productivity. Ph.D. Thesis, Iniv. Nebraska, Lincoln.

Roder, W., E. Anderhalden, P. Gurung, and P. Dukpa (1992). Potato intercropping systems with maize and faba bean. Amer. Potato J. 69:195-202.

Roder, W., S. C. Mason, M. D. Clegg, and K. R. Kneip (1989). Yield-soil water relationships in sorghumsoybean cropping systems with different fertilizer regimes. Agronomy J. 81:470-475.

Roder, W., S. C. Mason, M. D. Clegg, et al. (1988). Plant and microbial responses to sorghum-soybean cropping systems and fertilizer management. Soil Sci. Soc. Amer. J. 52:1337-1342.

Rodriguez-Garcia, J. and N. Diaz (1981). Effect on tanier yields of artificial shade levels and intercropping with plantains tropical root crop. J. Agric. Univ. Puerto Rico Agric. Expt. Sta., Rio Piedras 65(4):326-330.

Rogers, D. D., D. S. Chamblee, J. P. Mueller, and W. V. Campbell (1985). Fall no-till seeding of alfalfa into tall fescue influenced by time of seeding and grass and insect suppression. Agronomy J. 77:150-157.

Rogers, D. D., D. S. Chamblee, J. P. Mueller, and W. V. Campbell (1983). Fall sod-seeding of ladino clover into tall fescue as influenced by time of seeding and grass and insect suppression. Agronomy J. 75:1041-1046.

Rogers, D. D., D. S. Chamblee, J. P. Mueller, and W. V. Campbell (1985). Conventional and no-till establishment of ladino clover as influenced by time of seeding and insect and grass suppression. Agronomy J. 77:531-538.

Roltsch, W. J. and S. H. Gage (1990). Influence of bean/tomato intercropping on population dynamics of the potato leafhopper (Homoptera: Cicadellidae). Environ. Entomol. 19:534-543.

Roman, F. M., A. Beale, and H. Irizarry (1991). Intercropping to control weeds in yam (Dioscorea rotundata) and sweet potato (Ipomoea batatas). J. Agric., Univ. Puerto, 75:11-18.

Rommann, L. M., W. E. McMurphy, and B. D. Boyer (1973). Tall fescue in bermudagrass. Oklahoma Ext. Facts no. 2564.

Roquib, A., A. L. Kundu, and B. N. Chatterjee (1973). Possibility of growing soybean (Glycine max) in association with other crops. Indian J. Agric. Sci. 43:792-794.

Rose, S. J., O. C. Burnside, J. E. Specht, and B. A. Swisher (1984). Competition and allelopathy between soybeans and weeds. Agronomy J. 76:523-528.

Roskam, J. (1977). Models of analysis of polyculture enterprises: cattle rearing. Technical and economic data based on Volvestre Region (France). Inf. Agric. 39, 102 pp. 
Rosset, P. M., R. J. Ambose, A. G. Power, and A. J. Hruska (1984). Overyielding in polycultures of tomato and bean in Costa Rica (Intercropping). Trop. Agric. 61:208-212, 247.

Rossiter, R. C. and M. J. Palmer (1981). An analysis of seed yield in some strains of subterranean clover Trifolium subterraneum when grown in binary mixtures. Aust. J. Agric. Res. 32(3):445-452.

Rourke, M. K. (1991). Management of a denuded landscape by Yayasan Tananua, a farmer run cooperative, in NTT, Indonesia. Proc. Soc. Amer. For. Natl. Conv., Bethesda, Md, pp. 601-602.

Roy Sharma, R. P., H. N. Sharma, and S. N. Singh (1975). Parallel cropping with arhar. Paper, All India Kharif Pulse Workshop, IARIU, New Delhi.

Roy, A. R., B. C. Sasmal, and A. K. Bhattacharjee (1990). Effects of intercropping oilseeds and pulses in roselle (Hibiscus sabdariffa). Expl. Agric. 26:407-411.

Roy, R. P. and H. C. Thakur (1981). Studies on intercropping in long duration pigeonpea on sandy loam soil of North Bihar, India. Indian J. Agron. 26:77-82.

Roy, S. B. and M. N. Shahani (1970). Intercropping of legumes in hybrid maize. Allahabab Farmer 44(1/2):49-53.

RRIM (Rubber Res. Inst. Malaya). (1975). Maize, an intercrop for small holders. Rubber Res. Inst. Malaysai, Agric. Series Rep. I.

Rumbaugh, M. D., D. A. Johnson, and G. A. Van Epps (1982). Forage yield and quality in a Great Basin shrub, grass, ans legume pasture experiment. J. Range Mgt. 35:604-609.

Rusland, G. A., L. E. Sollenberger, K. A. Albrecht, et al. (1988). Animal performance ln limpograssaeschynomene and nitrogen-fertilized limpograss pastures. Agronomy J. 80:957-962:

Russell, J. (1986). Putting in a row crop while your tree crop slowly grows. Yearb Calif. Macad Soc., The - Society 32:37-39.

Russell, J. T. (1986). Effects of component densities and nitrogen fertilization on efficiency and yield of a maize/soybean intercrop. M. S. Thesis, Univ. Maryland, College Park.

Russell, J. T. and R. M. Caldwell (1989). Effects of component densities and nitrogen fertilization on efficiency and yield of a maize/soyabean intercrop. Expl. Agric. 25:529-540.

Russelle, M. P. and W. L. Hargrove (1989). Cropping systems: Ecology and management. In Nitrogen Management and Groundwater Protection (ed: R. F. Follett). Elsevier Science Publ. Co., New York, pp. 277-317.

Russelle, M. P., O. B. Hesterman, C. C. Sheaffer, and G. H. Heichel (1987). Estimating nitrogen and rotation effects in legume-corn rotations. In The Role of Legumes in Conservation Tillage Systems (ed: J. F. Power). Proc. Natl. Conf. (SCS), Univ. Georgia, Athens, GA.

Russo, S. L. (1986). The introduction of forage legumes into Gambian farming systems. In Potentials of Forage Legumes in Farming Systems of Sub-Saharan Africa (ed: I. Haque et al.). Proc. Workshop ILCA, Addis Ababa, Ethiopia, pp. 255-264.

Ruthenberg, H. (1971). Farming Systems in the Tropics. Clarendon Press, London, 313 pp .

Ruthenberg, H. (1974). From shifting cultivation to semi-permanent and permanent farming in the African Savanna. Proc. Intl. Workshop on Farming Systems, ICRISAT, Hyderabad, India, pp. 325349.

Ruttle, J. (1976). Mixing and matching produces results: Intercropping trials at the new Organic Gardening Experimental Farm at Emnmaus, Pennsylvania point the way to more food production on less land. Org. Gard. Farm. 23(7):41-45.

Ryan, J. G et al. (1974). Socio-economic aspects of agricultural development in the semi-arid tropic. Proc. Intl. Workshop on Farming Systems, ICRISAT, Hyderabad, India, pp. 389-432.

Saadullah, M. and S. C. Das (1987). Integrated crop and small ruminant systems in Indonesia. In Small Ruminant Production Systems in South and Southeast Asia (ed: C. Devendra), pp. 203-222.

Sachan, J. N. (1987). Pigeonpea pest management in India under major farming systems. Australian Centre Intl. Agric. Res. (ACIAR), pp. 298-299.

Sagwal, S. S. (1986). Implications of agri-silviculture for a sound land use system. In Agroforestry Systems, A New Challenge (ed: P.K. Khosla, S. Puri, and D. K. Khurana). Indian Soc. Tree Sci., pp 197-205.

Sahu, B. N. (1970). Intercropping Rauwolfia serpentina. Indian J. Agron. 15(3):229-235. 
Saini, S. S., J. P. Singh, and A. S. Faroda (1982). Economics of intercropping in arhar and its residual effect on succeeding wheat crop (Mungbean, urdbean, cowpea, soyabean and Pennisetum americanum). Agric. Sci. Dig. 2:205-207.

Sakai, K. I. (1955). Competition in plants and its relation to selection. Cold Springs Harbor Symp. Quant. Biol. 20:137-157.

Salako, F. K., R. Lal, and M. J. Swift (1995). Intercropping oil palm (Elaeis guineensis) with cocoyam (Xanthosoma sagittifolium) on windrows and non-windrows in southern Nigeria. J. Sustainable Agric. 6:47-60.

Salter, P. J., J. M. Akehurst, and G. E. L. Morris (1985). An agronomic and economic study of intercropping brussels sprouts and summer cabbage. Expl. Agric. 21:153-167.

Salter, P. J., J. M. Akehurst, and G. E. L. Morris (1986). An agronomic and economic study of intercorpping parsnips with early carrots and leeks with salad onions. Res. Dev. Agric. 3:71-77.

Samui, R. C., A. Roy, and P. Bhattacharyya (1984). Effect of intercropping on yield and yield attributes of groundnut and sunflower. Z. Acker Pflanzenbau J. Agron. Crop Sci. 153:407-411.

Samui, R. C., A. Roy, and P. Bhattacharyya (1984). Effect of intercropping on growth parameters of groundnut and sunflower. Z. Acker Pflanzenbau J. Agron. Crop Sci. 153:161-166.

Samui, R.C., A. Roy, and B. K. Maiti (1987). Intercropping of groundnut and sesame $\mathbf{n}$ approach for increasing productivity of oilseeds. In Crop Productivity: Proc., Workshop "Increasing Crop Productivity" (ed: H.C. Srivastava, Bhaskaran, and K.K.G). pp.435-444.

Sanandachari, A. and P. A. Rao (1980). Intercropping rice fallows cotton with pulses. Cotton Dev. 10(1/2):5-6.

Sandhu, J. S. and H. S. Toor (1983). Preliminary studies on dietary overlap of fishes in a polyculture. Indian J. Ecol. 10(2):322-326.

Sanford, J. O. (1979). Establishing wheat after soybeans in double-cropping. Agronomy J. 71:109-112.

Sanford, J. O. (1982). Straw and tillage management practices in soybean-wheat double-cropping Agronomy J. 74:1032-1035.

Sanford, J. O. and J. E. Hairston (1984). Effects of N fertilization on yield, growth, and extraction of water by wheat following soybeans and grain sorghum. Agronomy J. 76:623-627.

Sanford, J. O., B. R. Eddleman, S. R. Spurlock, and J. E. Hairston (1986). Evaluating ten cropping alternatives for the Midsouth. Agronomy J. 78:875-880.

Sanford, J. O., D. I. Myhre, and N. C. Merwine (1973). Double-cropping systems involving no-tillage and conventional tillage. Agronomy J. 65:978-982.

Sangakkara, R. (1994). Growth, yield and nodule activity of mungbean intercropped with maize and cassava. J. Sci. Food Agri. 66:417-421.

Sankaran, S. and N. Balasubramanian (1982). Intercropping of cotton. Cotton Dev. 12(1/2):23-27.

Sankarnaraynan, P. and B. K. Sahi (1980). Intercropping sugarcane with rice varieties. Indian J. Agron. 25:116-121.

Santa-Cecelia, F. C. S. and M. A. P. Ramalho (1982). Comportamento de cultivares de feijao em monocultivo e em associadas com milho. Ciencia Pratica 6:45-54.

Santa-Cecilia, F. and C. Vieira (1978). Associated cropping of beans and maize. I. Effects of bean cultivars with different growth habits. Turrialba 28:19-23.

Santhirasegaram, K. and J. N. Black (1968). The relationship between light beneath wheat crops and growth of undersown clover. J. British Grass. Soc. 23:234-239.

Santoso, B. (1980). Pengaruh tanaman sela tomat dan bawang daun terhadap populasi ulat Plutella maculipennis Curt. pada pertanaman kubis. Bull. Penelitian Hortik. Jakarta, Lembaga Penelitian Hortikultura 8(3):19-27.

Saproo, M. L.. M. Yaseen, and A. Husain (1993). Productivity of rose (Rosa damascena Mill) with intercrops under temperate conditions. J. Essent. Oil Res. 5:191-198.

Saraf, C. S. and D. E. Rajat (1975). Intercropping with legumes. (A review). Indian J. Genet. Pl. Breed. 35(2):216-220.

Saraf, C. S. and R. De (1975). Intercropping with legumes. Indian J. Genet. Pl. Breed. 35(2):209-215.

Saraf, C. S., A. Singh, and I. P. S. Ahlawat (1975). Studies in intercropping of compatible crops with pigeonpea. Indian J. Agron. 20(2):127-130. 
Saraf, C. S., A. Singh, and I. P. S. Ahlawat (1976). Intercropping of compatible crops with pigeonpea. Indian J. Genet. Pl. Breed. 35(2):248-252.

Saran, G. and G. Giri (1983). Intercropping of dryland castor planted in different dates and planting systems with grain legumes. Indian J. Agron. 28:362-368..

Sarig, S. (1981). The Mugilidae in polyculture in fresh and brackish water fishponds. Intl. Biol. Programme, Cambridge, No. 26, pp. 391-409.

Sarker, N. R., M. Giasuddin, M. M. Islam, et al. (1994). Effects of intercropping, seedling rate and fertilizer on fodder production in the low lying area of Bangladesh. Asian-Australasian J. Animal Sci. 7:57-61.

Sastrawinata, S. E. (1976). Nutrient uptake, insect, disease, labor use, and productivity characteristics of selected traditional intercropping patterns which together affect their continued use by farmers. Ph.D. Thesis, Univ. Philippines, Los Banos.

Satpathy, J. M., M. S. Das, and K. Naik (1977). Effect of multiple and mixed cropping on the incidence of some important field crop pests. J. Ento. Res. 1(1):78-85.

Satyanarayana, D. V. and M. R. Reddi (1979). Studies on intercropping in grain sorghum. Indian J. Agron. 24(2):223-224.

Saxena, K. N., A. P. Okeyo, K. V. Seshu-Reddy, et al. (1989). Insect pest management and socioeconomic circumstances of small-scale farmers for food crop production in western Kenya: a case study. Insect Sci. Appl. 10:443-462.

Saxena, M. C. (1972). Concept of parallel multiple cropping. Proc. Symp. MuJtiple Cropping, New Delhi, Indian Soc. Agronomy.

Saxena, M. C. and D. S. Yadav (1971). How about mixed cropping in short-duration arhar? Indian Farmer 20(11):41, 45.

Saxena, M. C. and D. S. Yadav (1975). Some agronomic considerations of pigeonpeas and chickpeas. Proc. Intl. Workshop on Grain Legumes, ICRISAT, Hyderabad, India.

Saxena, M. C. and D. S. Yadav (1976). Parallel cropping of soybean with pigeonpea under humid subtropical conditions of Pantnagar. Indian J. Agron. 21:131-134.

Saxena, M. C. and R. P. Sharma (1978). Comparative performance of winter cereals, pulses and oilseeds in pure and mixed cropping under upland and lowland rainfed conditions of Tarai. Pantnagar $\mathrm{J}$. Res. 3:41-45.

Saxena, M. C. and R. P. Shrama (1978). Studies on gram chickpeas in mixed cropping under unirrigated conditions of Tarai. Pantnagar J. Res. 3:32-35.

Schalbroeck, J. J., L. Opdecamp, and R. Baragengana (1988). Differential reaction of wheat and triticale to physical and chemical properties of soils in Mugamba, Burundi. In Fifth Regional Wheat Workshop Eastern, Central Southern Africa, Indian Ocean (ed: M. van Ginkel and D. G. Tanner). Intl. Maize Wheat Impr. Center, pp. 127-140.

Schepers, A. and L. Sibma (1976). Yield and dry matter content of early and late potatoes, as affected by monoculture and mixed cultures. Potato Res. 19:73-90.

Schilling, R. (1965). L'Arachide en cultures associees avec les cereales. Oleagineux 20(11):673-676.

Schlippe, P. de. (1956). Shifting Cultivation in Africa. The Land Systems. Routoledge and Kegan, London.

Schlough, D. A., J. M. Scholl, and G. H. Tenpas (1977). Performance of four perennial grasses grown alone, with rates of nitrogen or with alfalfa or birdsfoot trefoil at Ashland, Wisconsin. Wisconsin Res. Bull. R2908.

Schmid, A. R. and R. Behrens (1972). Herbicides vs. oat companion crops for alfalfa establishment. Agronomy J. 64:157-159.

Schmidt, D. R. and G. H. Tenpas (1965). Seasonal response of grasses fertilized with nitrogen compared to a legume-grass mixture. Agronomy J. 57:428-431.

Schreiber, M. M. (1967). A technique for studying weed competition in forage legume establishment. Weeds 15:1-9.

Schroder, D. and P. F. Warnken (1981). Yellow yams, sweetpotatoes, red peas, onions, sweet corn, carrots, radishes. Turrialba. San Jose, Costa Rico, Inst. Interamericano de Ciencias, Agricolas 31:63-68.

Schroeder, G. L. (1983). Sources of fish and prawn growth in polyculture ponds as indicated by delta C analysis carbon isotopes. Aquaculture 35(1):29-42. 
Schuerger, A. C. and P. D. Laible (1994). Biocompatibility of wheat and tomato in a dual culture hydroponic system. HortScience 29:1164-1165.

Schulte, D. (1980). The development of under- and above ground plant masses by intercropping in relation to location and seed time. Bonn, 154, 2 pp.

Schultz, B. B. (1988). Reduced oviposition by green lacewings (Neuroptera: Chrysopidae) on cotton intercropped with corn, beans, or weeds in Nicaragua. Environ. Entomol. 17:229-232.

Schultz, B., C. Phillips, P. Rosset, and J. Vandermeer (1982). An experiment in intercropping cucumbers and tomatoes in Southern Michigan. Scientia Hort. 18:1-8.

Schultz, B., H. McGuinness, B. Horwith, et al. (1987). Effects of planting densities, irrigation, and hornworm larvae on yields in experimental intercrops of tomatoes and cucumbers. J. Amer. Soc. Hort. Sci. 112:747-755.

Schultz, M. A., A. E. Erickson, J. A. Bronson (1987). Intercropping corn and forage legumes in Michigan. In The Role of Legumes in Conservation Tillage Systems (ed: J.F. Power). Ankeny, Iowa, pp. 91-92.

Schuster, D. J. (1992). Integration of natural enemies for management of the sweetpotato whitefly and associated disorders on mixed-cropped vegetables. Sustainable Agric. Res. Educ. (SARE) or Agric. in Concert with the Environ. (ACE) res. proj., $29 \mathrm{pp}$.

Schutz, W. M. and C. A. Brim (1967). Inter-genotypic competition in soybeans: I. Evaluation of effects and proposed field plot design. Crop Sci. 7:371-376.

Schutz, W. M. and C. A. Brim (1971). Inter-genotypic competition in soybeans. III. An èvaluation of stability in multiline mixtures. Crop Sci. 7:684-689.

Schutz., W. M., C. A. Brim, and S. A. Usanis (1968). Inter-genotypic competition in plant populations: I. Feedback systems with stable equilibria in populations of autogamous lines. Crop Sci. 8:61-66.

Schweitzer, L. E., W. E. Nyquist, J. B. Santini, and T. M. Kimes (1986). Soybean cultivar mixtures in narrow-row, noncultivatable production system. Crop Sci. 26:1043-1046.

Scott, H. D., C. L. Griffis, D. W. Brewer, and L. R. Oliver. (1978). Simulation of plant competition. Trans. ASAE 21:813-821.

Scott, T. W. and R. F. Burt (1987). Use of red clover in corn polyculture systems. In The Role of Legumes in Conservation Tillage Systems (ed: J.F. Power). Ankeny, Iowa, pp. 101-103.

Scott, T. W., J. Mt. Pleasant, R. F. Burt, and D. J. Otis (1987). Contributions of ground cover, dry matter, and nitrogen from intercrops and cover crops in a corn polyculture system. Agronomy J. 79:792798.

Searle, P. G.'E. and R. A. Nance (1981). Effect of maize + legume intercropping systems and fertilizer nitrogen on crop yields and residual nitrogen. Field Crops Res. 4(2):133-145.

Sefanaia, S., S. Chandra, and D. M. Etherington (1982). A review of recent research on intercropping under coconuts (Effects on yields). Fiji. Agric. J. 44:31-36.

Seigler, D. S. (1996). Chemistry and mechanisms of allelopathic interactions. Agronomy J. 88:876-875.

Sekawin, M. and M. Prevosto (1973). Influence of the tillage and of the intercropping on the technical and economical results of a poplar stand located in the region of Piacenza. Cellul. Carta. 24(8):318.

Sen, D. N. (1988). Key factors affecting weed-crop balance in agroecosystems. In Weed Management in Agroecosystems: Ecological Approaches (ed: M. A. Altieri and M. Liebman). CRC Press, Boca Raton, Fla., pp. 157-182.

Senaratne, R. and D. S. Ratnasinghe (1993). N supply by groundnuts to maize in a maize plus groundnut intercropping system, as affected by the genotype. Biol. Fert. Soils 15:215-219.

Senaratne, R, N. D. L. Liyanage, and D. S. Ratnasinghe (1993). Effect of K on nitrogen fixation of intercrop groundnut and the competition between intercrop groundnut and maize. Fert. Res. 34:914.

Senaratne, R., N. D. L. Liyanage, and R. J. Soper (1995). Nitrogen fixation of and N transfer from cowpea, mungbean and groundnut when intercropped with maize. Fert. Res. 40:41-48.

Sengonca, C. and B. Frings (1988). The influence of Phacelia tanacetifolia to pests and beneficial insect in sugarbeet plots. Pedobiologia 32:311-316.

Sengupta, K., K. K. Bhattacharyya, and B. N. Chatterjee (1985). Intercropping of upland rice with blackgram (Vigna mungo (L.)). J. Agric. Sci. 104:217-221. 
Serpa, J. E. S. and A. C. Barreto (1982). Competicao de cultivares de feijao em consorciacao com e milho nas mocro regios homogeneas 123 et 130 de Estado de Sergipe. EMBRAPA/UEPAE de Aracuja, No. 6.

Seshadri, C. R., S. G. Aiyadurai, and N. Srinvasalu. (1956). Groundnut mixed-cropping experiment. Madras Agric. J. Coimbatore 43:496-504.

Seshu-Reddy, K. V. (1990). Cultural control of Chilo spp. in graminaceous crops. Insect Sci. Appl. 11:703-712.

Sethi, P. and K. S. Parashar (1981). Studies on the effect of intercropping and nitrogen levels on the yield of spring planted sugarcane. Indian Sugar 31(2):95-100.

Shackel, K. A. and A. E. Hall (1984). Effect of intercropping on the water relations of sorghum and cowpea. Field Crops Res. 8:381-387.

Shade, L. (1973). How to find space in your garden for strawberries. Org. Gard. Farm. 20(12):70-72.

Shaffer, J. A., G. A. Jung, J. S. Shenk, and S. M. Abrams (1990). Estimation of botanical composition in alfalfa/ryegrass mixtures by near infrared spectroscopy. Agronomy J. 82: 669-673.

Shalaby, F. F., E. A. Kares, A. A. Ibrahim (1984). Effect of intercropping maize in cotton fields on the attractiveness of predaceous insects (Orius, Scymnus, Coccinella undecimpunctata, Chrysopa carnea, Paederus alfierii, Egypt). Ann. Agric. Sci. Moshtohor 20:109-123.

Shama Bhat, K. and K. B. Abdul Khader (1970). Inter- and mixed cropping in Arecanut gardens. Indian Farmer 20(3):35, 45.

Shanahan, J. F., R. L. Anderson, and B. W. Greb (1988). Productivity and water use of proso millet grown under three crop rotations in the Central Great Plains. Agronomy J. 80:487-492.

Shaner, W. W., P. F. Philipp, and W. R. Schmehl (1982). Farming Systems Research and Development: Guidlines for Developing Countries. Westview Press, Boulder, CO.

Shanmugam, K. S. (1976). Hedge planting for intercropping in coconut. Farmer Parliament 11(5):15-16, 25.

Shannon, D. A. and N. C. Lawson (1975). Field pea mixtures for protein production. The MacDonald J. 36(4):9-11.

Shanthamallaiah, N. R. and K. M. Krishnappa (1978). Studies on intercropping with sunflower. J. Agric Sci. 12:41-44.

Sharaiha, R. and S. Gliessman (1992). The effects of crop combination and row arrangement in the intercropping of lettuce, favabean and pea on weed biomass and diversity and on crop yields. Biol. Agric. Hort. Intl. J. 9:1-13.

Sharaiha, R. K. (1986). Evaluation of row intercropping of potato, broad bean and corn under Jordan Valley conditions. Dirasat, Univ. Jordan, 13:115-126.

Sharaiha, R. K. and N. I. Haddad (1986). Influence of intercropping row arrangements and plant density on the performance of potato/fababean and cabbage/fababean when grown in association. Dirasat, Univ. Jordan, 13:127-146.

Sharma, H. K. (1981). Evaluaton of pigeonpea genotypes under sole and mixed cropping. Indian J. Genet. Plant Breed. 41(3):43.

Sharma, K. N. and J. S. Sodhi (1979). Effect of fertilizer application in an intercropping system. Indian J. Agric. Res. 13:47-50.

Sharma, R. A. (1979). Intercropping in sugarcane pays more profit. Farmer Parliament 14(3):11-12.

Sharma, S. B., T. J. Rego, M. Mohiuddin, and V. N. Rao (1996). Regulation of population densities of Heterodera cajani and other plant-parasitic nematodes by crop rotations on vertisols in semi-arid tropical production systems in India. J. Nematology 28:244-251.

Sharma, S. C. and H. G. Singh (1972). Effect of methods of intercropping maize with cowpea on the production of animal feed. Indian J. Agric. Sci. 42(10):904-908.

Sharma, S. C. and H. G. Singh (1974). Effect of methods of intercropping maize and cowpea on the quality of forage. Madras Agric. J. Coimbatore 61(8):392-397.

Sharma, S. K. and H. Mehta (1991). Manifestation of genetic diversity for physiological traits in soybean under two cropping systems. Trop. Agric. 68:202-206.

Sharma, S. K., H. Mehta, and N. D. Rana (1986). A multivariate analysis of soybean genotypes grown under different cropping systems. J. Agron. Crop Sci. Z. Acker Pflanzenbau 156:81-90. 
Sharpe, R. R., J. T. Touchton, F. C. Boswell, and W. L. Hargrove (1984). Effect of applied and residual P on double-cropped wheat and soybean under conservation tillage management. Agronomy J. 76:3135.

Shaw, T. (1972). Early agriculture in Africa. H. Historical Soc. Nigeria VI( 2):144-192.

Shaxson, L. and L. W. Tauer (1992). Intercropping and diversity: an economic analysis of cropping patterns on smallholder farms in Malawi. Expl. Agric. 28:211-228.

Sheaffer, C. C. (1988). Effect of competition on legume persistence. In Persistence of Forage Legumes (ed: G. C. Marten et al.). Proc. Trilateral Workshop, ASA, CSSA, and SSSA, Madison WI, pp. 327-333.

Sheaffer, C. C., D. K. Barnes, and G. C. Marten (1988). Companion crop vs. solo seeding: Effect on alfalfa seeding year forage and $\mathrm{N}$ yields. J. Prod. Agric. 1:270-274.

Sheaffer, C. C., D. W. Miller, and G. C. Marten (1990). Grass dominance and mixture yield and quality in perennial grass-alfalfa mixtures. J. Prod. Agric. 3:480-485.

Sheaffer, C.C., G. C. Marten, and D. L. Rabas (184). Influence of grass species on composition, yield, and quality of birdsfoot trefoil mixtures. Agronomy J. 76:627-632.

Sheikh, M. I. (1981). Interim results on the performance of new poplar clones. Pak. J. For. Pesh. 31(4):192-193.

Sheldrick, R. D., R. H. Lavender, amd V. J. Tewson (1986). The effects of frequency of defoliation, date of first cut, and heading date of a perennial ryegrass companion on yield, quality, and persistence of diploid and tetraploid red clover. Grass Foragē Sci. 41:137-149.

Shelke, V. B. (1977). Studies on crop geometry in dryland intercrop systems. Ph.D. Thesis, Marathwada Agric. Univ., Parbhani, Maharashtra, India.

Shelke, V. B. and U. M. Bhaskara Rao (1976). Systematic design for pairing the rows. Paper, Annual Workshop of All India Coordinated Sorghum Inprovement Project, Parbhani, India.

Shelke, V.B. and Ch. Krishnmoorthy (1978). Studies on crop geometry in dryland intercrop systems. Paper, Natl. Symp. on Intercropping of Pulse Crops, Indian Agric. Res. Inst., New Delhi, India.

Shelton, H. M. and L. R. Humphreys (1975). Undersowing rice (Oryza sativa) with Stylosanthes quianensis. II. Delayed sowing time and crop variety. Expl. Agric. 11:97-101.

Shelton, H. M. and L. R. Humphreys (1975). Undersowing rice (Oryza sativa) with Stylosanthes guyanensis. Expl. Agric. 11:89-111.

Shepherd, K. D., J. K. Ndufa, E. Ohlsson, et al. (1997). Adoption potential of hedgerow intercropping in maize-based cropping systems in the highlands of western Kenya. 1. Background and agronomic evaluation. Expl. Agric. 33:197-209.

Shetty, R. V. R. (1983). The status of weed control in intercropping systems in the Tropics (Semi-arid regions of India, west and east Africa, northeast Brazil and central America). FAO Plant Prod. Prot. Paper Issue 44, pp. 119-125.

Shetty, S. V. R. (1978). Weed control in sorghum in the tropics. Paper, $10^{\text {th }}$ Annual Meeting of Weed Sci. Soc, Manila, Philippines, 14 pp.

Shiddoway, F. H. and A. P. Bonnet (1975). Water and wind erosion aspects of multiple cropping. Multiple Cropping Symp. Spec. Publ. 27, ASA, Madison, WI, pp. 317-336.

Shipley, P. R., J. J. Meisinger, and A. M. Decker (1992). Conserving residual corn fertilizer nitrogen with winter cover crops. Agronomy J. 84:869-876.

Shorter, R. and K. J. Frey (1979). Relative yields of mixtures and monocultures of oat genotypes. Crop Sci. 19:548-553.

Shrader, W. D., W. A. Fuller, and F. B. Cady (1966). Estimation of a common nitrogen response function for corn in different crop rotations. Agronomy J. 58:397-401.

Shrivastava, U. K., R. P. Yadav, V. K. Rastogi, et al. (1983). Intercropping of maize with legumes under various nitrogen levels. Indian J. Agron. 28:156-158.

Shukla, D. S. \{1974). Influence of seed and root exudates on germination of sclerotia of Ozonium texanum var. parasiticum, the incitant of gram chickpea wilt, and effect of mixed cropping in relation to the wilt development. Indian Phytopathol. 27:97-100.

Siame, J., R W. Willey, and S. Morse (1997). A study of the partitioning of applied nitrogen between maize and beans in intercropping. Expl. Agric. 33:35-41. 
Siddappaji, C. and G. P. Channabasavanna (1981). Effect of intercropping of the incidence of pigeonpea sterility mosaic transmitted by Aceria cajani (Acari: Eriophyidae) Cajanus. Cajan, India. Contrib. Acarol. Bangalore, India, pp. 80-84.

Siddeswaran, K. and C. Ramaswami (1987). Inter-cropping and border-cropping of compatible crops in finger millet (Eleusine coracana Gaertn.) under garden land conditions. J. Agron. Crop Sci. Z. Acker Pflanzenbau 158:246-249.

Siddoway, F. H. and A. P. Barnett (1976). Water and wind erosion control aspects of multiple cropping. In Multiple Cropping (ed: P. I. Papendick, P. A. Sanchez, and G. B. Tripplett). ASA Spec. Publ. No. 27 ASA, Madison, WI.

Sidhu, M. S., J. S. Sawhney, and Baljinder (1988). Production potential of kharif pulses in association with maize. J. Agric. Sci. 112:525-527.

Sieverding, E. and D. E. Leihner (1984). Influence of crop rotation and intercropping of cassava with legumes on VA (Vesicular-arbuscular) mycorrhizal symbiosis of cassava (Manihot esculenta, nutrition, yields, Colombia). Plant Soil 80:143-146.

Simmons, S. R., N. P. Martin, C. C. Sheaffer, et al. (1992). Companion crop forage establishment: Producer practices and perceptions. J. Prod. Agric. 5:67-72.

Simon, W. and P. Asmus (1974). Intercropping in crop rotations with high cereal component. Feldwirtschaft 15(6):262-264.

Simpson, J. R. (1965). The transference of $\mathrm{N}$ from pasture legumes to an associated grass under several systems of management in pot culture. Aust. J. Agric. Res. 16:915-926.

Simpson, J. R. (1976). Transfer of nitrogen from three pasture legumes under periodic defoliation in a field environment. Aust. J. Agric. Animal Husb. 16:863-870.

Singh, A. (1985). Cultivation of grain legumes in arid zone. Indian Farming 35:27-28.

Singh, A. L. and P. K. Singh (1990). Intercropping of Azolla biofertilizer with rice at different crop geometry. Trop. Agric. 67:350-354.

Singh, A. L., P. K. Singh, and P. L. Singh (1988). Effect of spacing and row orientation on the growth and nitrogen fixation of Azolla and their effects on rice. J. Agric. Sci. 110:567-572.

Singh, A. L., P. K. Singh, and P. Lata (1988). Effects of different levels of chemical nitrogen (urea) on Azolla and blue-green algae intercropping with rice. J. Fert. Use Technol. 17:47-59.

Singh, A., I. P. S. Ahlawat, and R. B. Lal (1983). Effect of planting pattern, intercropping and application of phosphate on the yields of pigeonpea and the succeeding crop of wheat (Cajanus cajan, Triticum aestivum, India). Indian J. Agric. Sci. 53:556-562.

Singh, A., I? P. S. Ahlawat, and R. B. Lal (1983). Effect of planting pattern, intercropping and application of phosphate on the yields of pigeonpea and the succeeding crop of wheat. Indian J. Agric. Sci. 53(7):556-562.

Singh, A., M. Singh, and D. V. Singh (1986). The successful use of intercropping for weed management in medicinal yam (Dioscorea floribunda Mart and Gal). Trop. Pest Mgt. 32:105-107, 188-189, 192.

Singh, B. (1987). Pulse production in Fiji. Australian Centre Intl. Agric. Res. (ACIAR), p. 243.

Singh, B. P. (1985). Effect of intercropping with pearlmillet on productivity, profitability and water use on aridisols. Indian J. Agron. 30:408-413.

Singh, B. P. (1987). Synergetic effect of mungbean intercrop on dryland castorbean. Trans. Indian Soc. Desert Technol. 12:77-82.

Singh, B. P. and H. C. Sharma (1981). Intercropping of pearl millet with green gram and groundnut in dryland. Proc. Natl. Symp. Crop Manage. pp . 77-83.

Singh, B. P. and J. P. Singh (1987). Studies on crop geometry with intercropping management in dryland castorbean. Trans. Indian Soc. Desert Technol. 12:13-20.

Singh, B., D. S. Rana, and G. S. Sekhon (1978). Some measures of reducing leaching loss of nitrates beyond potential rooting zone. IV. Intercropping. Plant Soil. 49(3):633-639.

Singh, B., S. S. Yazdani, R. Singh, and S. F. Hameed (1984). Effect of intercropping on the incidence of sweet potato weevil, Cylas formicarius Fabr., in sweet potato (Ipomoea batatas Lam.). J. Entomol. Res. 8:193-195.

Singh, C. M. and P. Chand (1980). Note on economics of grain legume intercropping and N nitrogen fertilization in maize. Indian J. Agric. Res. 14:62-64. 
Singh, C. M. and W. S. Guleria (1979). Effect of intercropping and fertility levels on growth, development and yield of maize (Zea mays L.). Food Farm. Agric. 10(7):242-244.

Singh, C. M., S. C. Modgal, H. B. Singh, and B. R. Sood (1977). Studies on mixed cropping in wheat under rainfed conditions in Kulu Valley. Food Farm. Agric. 8(9):19-20.

Singh, D. P. and P. K. Singh (1986). Relative effects of Azolla pinnata and its combination with chemical nitrogen fertilizer on growth, yield and N uptake of rice. J. Agric. Sci. 106:107-112.

Singh, D. P. and P. K. Singh (1988). Effects of phosphorus and carbofuran on the growth and nitrogen fixation of Azolla pinnata and the yield of rice. Expl. Agric. 24:183-189.

Singh, D. P. and P. K. Singh (1995). Response of Azolla caroliniana and rice to phosphorus enrichment of the Azolla inoculum and phosphorus fertilization during intercropping. Expl. Agric. 31:21-26.

Singh, D. V. (1982). Economics of mixed cropping in the arid zone farming systems of Rajasthan, India. Ann. Arid Zone. Pungalpara 21(4):289-297.

Singh, H. (1975). Intercropping for more profitable dairy farming. Indian Farming 25(2):24, 26.

Singh, H. G. (1982). Present status of pulses research in Rajasthan. In Pulse Production, Constraints and Opportunities: Proc. Symp. on Increasing Pulse Production in India-(ed: H.C. Srivastava et al.), New Delhi, pp. 69-72.

Singh, H. P. (1982). Intercropping with arhar pays rich dividends (Cajanus cajan, India). Indian Farming 32:19-20.

Singh, I. D. and N. C. Stoskopp (1971). Harvest index in cereals. Agronomy J. 63:224-226.

Singh, J. N., P. S. Negi, and S. K. Tripathi (1973). Study on the intercropping of soybean with maize and jowar. Indian J. Agron. 18:75-78

Singh, J. P. and B. P. Singh (1988). Productivity of intercropping with brassicae sp. in chickpea on dryland. Trans. Indian Soc. Desert Technol. 13:1-6.

Singh, K. A. (1984). Response of forage green panic and veranostylo intercropping to fertilization. Indian J. Agron. 29:277-281.

Singh, K. A. (1985). Effect of phosphorus levels and veranostylo seed rate on the productivity of guineagrass and veranostylo intercropping. Indian J. Agron. 30:260-262.

Singh, K. A. and B. D. Patil (1984). Resource use and plant interference in relation to nutrients in buffelgrass and veranostylo association. Indian J. Agron. 29:356-362.

Singh, K. A. and M. Pal (1988). Productivity of pigeonpea-wheat cropping systems. J. Agric. Sci. 110:645-650.

Singh, K. A., B. D. Patil, and P. Rai (1984). Integration of forage-food production through intercropping in semi-arid region. Indian J. Agron. 29:510-515.

Singh, K. A., K. P. Niranjan, and A. Kumar (1985). Effect of row spacing on the productivity of bluepanic intercropped with butterflypea in semi-arid conditions. Indian J. Agron. 30:349-352.

Singh, K. and M. Singh (1981). Intercropping of urd with arhar pigeonpeas. Indian Farming 31:11-12.

Singh, K. C. and R. P. Singh (1977). Intercropping of annual grain legumes with sunflower. Indian J. Agric. Sci. 47(11):563-567.

Singh, K. C. and R. P. Singh (1978). Mixed cropping of maize (Zea mays) with cowpea (Vigna sinensis) and velvet bean (Stizolobium deeringianum) on the yield and chemical composition of fodder. Indian J. Dairy Sci. 31:28-33.

Singh, K., A. K. Bhattacharjee, and D. Ram (1978). Intercropping wheat and radish with potato (ware crop). J. Indian Potato Assoc. 5(3):137-140.

Singh, K.P. and O. N. Pandey (1992). Taungya in India. Sustainable Rural Dev. Ser. 1:128-132.

Singh, L. (1975). Breeding pulse crop varieties for inter and multiple cropping. Indian J. Gen. Pl. Breeding 35:221-228.

Singh, M. (1984). Effect of planting geometry on the yield of Cenchrus ciliaris Linn. in arid region. Ann. Arid Zone 23:-369.

Singh, M. 91986). Planting geometry simulation for grass-legume intercropping in the arid zone. Ann. Arid Zone 25:86-88.

Singh, M. and B. Gilliver (1983). Statistical analysis of intercropping data using a correlated error structure. Contributed Paper, 44th Session, Intl. Statistical Inst. Proc., pp. 158-163.

Singh, M. and H. S. Sekhon (1985). Potato-wheat-summer moongbean: a new inter/relay cropping system. Indian Farming 35:3-4, 40. 
Singh, M. and N. L. Joshi (1994). Performance of pearl millet-based intercropping systems under drought conditions. In Arid Soil Research and Rehabilitation, Taylor \& Francis, Washington, DC, pp. 277283.

Singh, M. and R. P. Singh (1985). Mineral content of grass (Cenchrus ciliaris Linn.) and grass-legume mixtures in various intercropping systems. Ann. Arid Zone 24:1-7.

Singh, M. and S. K. Singh (1975). Prospects of growing pulses under multiple and intercropping. Indian. J. Genet. Pl. Breed. 35(2): 216-220.

Singh, M. and S. L. Pandey (1963). Guar (Cyanopsis tetraglobona) as a shade crop for early potatos in the plains of north India. Indian J. Agron. 8:335-340.

Singh, M., R. S. Paroda, and T. K. Bhati (1984). Studies on intercropping in napier-bajra hybrid. Ann. Arid Zone 23:347-352.

Singh, N. B. and P. P. Singh (1984). Effect of intercropping with legumes on grain yield of maize and its residual effect on succeeding wheat. Indian J. Agron. 29:295-298.

Singh, N. B., P. P. Singh, and K. P. P. Nair (1986). Effect of legume intercropping on enrichment of soil nitrogen, bacterial activity and productivity of associated maize crops. Expl. Agric. 22:339-344.

Singh, P. and N. L. Joshi (1980). Intercropping of pearl millet Pennisetum typhoides in arid areas. Indian J. Agric. Sci. 50(4):338-341

Singh, P. P., S. K. Saini, P. S. Negi, and K. Kumar (1983). Studies on nitrogen economy in sugarcane through intercropping of green gram (Vigna radiata). Proc. Annu. Conv. Sugar Tech. Assoc. India, The Association, Issue $47^{\text {th }}$, pp. 193-203.

Singh, P. P., V. P. Nema, and P. K. Kaushal (1972). A study of intercropping sesamum with maize and mung beans. Indian J. Agren. 17(4):294-296.

Singh, R. A. and K. S. Rathi (1984). Economics of potato and potato plus mustard cultivation under different rates of nitrogen. Indian J. Agron. 29:555-556.

Singh, R. D. and P. Chand (1969). Intercropping maize with forage legumes. Indian J. Agron. 14:67-70.

Singh, R. K. and M. Singh (1980). Intercropping of pigeonpea in Eastern Uttar Pradesh. Indian J. Agron. 25(4):581-585.

Singh, R. K., N. Y. Kumar, K. N. R. Burman, and A. C. Roy (1982). Intercropping in areca gardens in North Bengal (India, betel nut and vegetable production). Indian Farming 32:13-15.

Singh, R. N. and K. M. Singh (1978). Influence of intercropping with beans, cowpeas, sorghum or pearlmillet on succession and population build up of insect pests in early variety of red gram. Indian J. Entomol. 40(4):361-375.

Singh, R. P. (1981). Crop failure and Intercropping in the semi-arid tropics of India. Prog. Rep. Int. Crops Res. Inst. Semi-Arid Trop., Andhra Pradesh, No. 21, 29 pp.

Singh, R. P. (1982). Constraints and opportunities of pulse production in drylands of India. In Pulse Production, Constraints and Opportunities: Proc. Symp. on Increasing Pulse Production in India-(ed: H.C. Srivastava. et al.), New Delhi, pp. 235-240.

Singh, R. P. and J. Venkateswarlu (1985). Role of all India coordinated research project for dryland agriculture in research development. Fert. News 30:43-55.

Singh, R. P. and M. V. R. Prasad (1976). Intercropping of short duration grain legumes in sown pastures and field crops. Indian J. Genet. P1. Breed. 35(2):271-275.

Singh, R. P., C. K. Ong, and N. Saharan (1989). Above- and below-ground interactions in alley cropping in semiarid India. Agrofor. Syst. 9:259-274.

Singh, R. R. and A. C. Roy (1982). Intercropping in areca gardens in North Bengal, India. Indian Farmer 32(9):13-15.

Singh, S. K., Y. L. Nene, and M. V. Reddy (1990). Influence of cropping systems on Macrophomina phaseolina populations in soil. Plant Dis. 74:812-814.

Singh, S. P. (1978). Intercropping studies of sorghum. Paper, Natl. Symp. on Intercropping of Pulse Crops, Indian Agric. Res. Inst., New Delhi, India.

Singh, S. P. (1981). Studies on spatial arrangement in sorghum-legume intercropping systems. J. Agric. Sci. 91(3):655-662.

Singh, S. P. and D. Jha (1984). Stability of sorghum-based intercropping systems under rainfed conditions. Indian J. Agron. 29:101-106. 
Singh, S. P. and D. Jha (1981). Stability of sorghum-based intercropping systems under conditions in India. Intl Symp. on 'Sorghum in the Eighties', ICRISAT, Hyderabad, India.

Singh, S. P. and O. P. Jain (1984). Stability studies in sorghum based intercropping systems under rainfed conditions in India. Z. Acker Pflanzenbau J. Agron. Crop Sci. 153:40-51.

Singh, S. P. and V. K. Srivastava (1981). A note on the economics of intercropping in autumn grown tomato. J. Hortic. Sci. 10(3/4):253-255.

Singh, S. P., R. C. Gautam, and V. R. Anjaneyulu (1979). Adding a competition-free period to intercrop component, a new concept. Proc. Intl. Workshop on Intercropping, ICRISAT, Hyderabad, India, pp. 25-29.

Singh, S., R. Singh, and O. S. Tomar (1973). Intercropping cotton with summer legumes in Punjab. Cotton Dev. 2(4):9-13.

Singh, S., U. S. L. Srivastava, and B. Singh (1983). Studies on planting system and intercropping in hybrid sorghum under rainfed conditions (Kanpur area). Indian J. Agron. 28:92-94.

Singh, T. and M. N. Sadaphal (1980). Effect of legumes on physical properties of soil in mixed cropping with maize. Indian J. Agron. 25(4):592-599.

Singh, T. and M. N. Sadaphal. (1981). Effect of legumes on moisture extraction and soil physical properties in mixed cropping with wheat, chickpeas, lathyrus, lentils. Indian J. Agron. 26(3):234239.

Singh, U. B. and S. K. Paliwal (1978). Intercropping of safflower and feenel in potato yields and returns. Inten. Agric. 15(12):24-25.

Singh, V. G. B., Y. P. Joshi, and S. S. Verma (1989). Studies on the productivity of Egyptian clover and oats under intercropping. Expl. Agric. 25:541-544.

Singh, Y. and G. R. Singh (1985). Performance of sugarcane and sugarbeet intercropping with varying sugarbeet population and nitrogen rates. Indian J. Agron. 30:445-449.

Singh, Y., G. R. Singh, and P. P. Singh (1984). Economic evaluation of sugarbeet-wheat intercropping. Indian J. Agric. Sci. 54:718-721.

Sinha, R. and S. S. L. Dwivedi (1982). Intercropping of tobacco and sugarcane in North Bihar, India. Tob. Res. 8(2):119-131.

Sinha, R., R. N. Mishra, A. K. Pandey, and S. S. L. Dwivedi (1982). Intercropping of tobacco and sugarcane in North Bihar (India). Tob. Res. 8:119-131.

Sinoquet, H. and P. Cruz (1995). Ecophysiology of Tropical Intercropping. Inst. Natl. de la /recherche Agronomique (INRA), Paris.

Sinoquet, H. and R. Bonhomme (1992). Modeling radiative transfer in mixed and row intercropping systems. Agric. For. Meteorol. 62:219-240.

Sitanggang, L. M. (1976). Evaluation of intercropping of Crotalaria usaramoensis and maize as a source of green manure on subsequent growings of potato and maize. Bull. Penelitian Hortik. 4(2):47-52.

Sitaram, M. S. and K. Krishnamurthy (1972). Studies on fibre properties of cotton varieties as influenced by planting dates and mixed cropping. Mysore J. Agric. Sci. 6(3):349-352.

Sivakumar, M. V. K. 1993. Growth and yield of millet and cowpea in relay and intercrop systems in the Sahelian zone in years when the onset of the rainy season is early. Expl. Agric. 29:417-427.

Sivakumar, M. V. K. and S. M. Virmani (1980). Growth and resource use of maize, pigeonpea and maize/pigeonpea intercrop in an operational research watershed. Expl. Agric. 16:377-386.

Sivan, P. (1984). Effect of some intercrops on taro. Proc. Sixth Symp. Intl. Soc. Trop. Root Crops, Intl. Potato Center (CIP), pp. 103-107.

Sjarifuddin, A., Soeharsono, and J. L. McIntosh (1975). Multiple cropping in Indonesia. Proc. Cropping Systems Workshop, IRRI, Los Banos, Laguna, Philippines, pp. 33-56.

Skarpol, B. J., K. A. Corey, and J. J. Meisinger (1987). Response of snap beans to tillage and cover crop combinations. J. Amer. Soc. Hort. Sci. 112:936-941.

Skousen, J. G. and C. A. Call (1984). Performance of range forage species interseeded in coastal bermudagrass on lignite overburden. Texas Agric. Expt. Sta., The Station, Issue 4253, pp. 181185.

Skovgard, H. and P. Pats (1996). Effects of intercropping on maize stemborers and their natural enemies. Bull. Entomological Res. 86:599-607. 
Slate, Jr. W. L. and B. A. Brown (1925). Corn and soybeans as a combination crop for silage. Storrs (Conn.) Expt. Sta Bull. 133.

Smith, A. E. (1982). Determining the legume fraction of a grass-legume mixture by pinitol analysis. Agronomy J. 74:157-159.

Smith, A. E. (1989). Interference with loblolly pine (Pinus taeda) seedling growth by three grass species. Weed Tecnol. 3:696-698.

Smith, A. E. and L. D. Martin (1994). Allelopathic characteristics of three cool-season grass species in the forage ecosystem. Agronomy J. 86:243-246.

Smith, C. A. and J. D. Gilpatrick (1980). Geneva leaf wetness detector. Plant Dis. 64(3):286-288.

Smith, C. R. and G. M. Prine (1982) Intercropping and double cropping of corn with green manure legumes in North Florida. Proc. Soil. Crop. Sci . Soc. Fla. 41:148-152.

Smith, C. W. and J. J. Varvel (1982). Double cropping cotton and wheat. Agronomy J. 74:862-865.

Smith, D, A., V. A. Jacques, and J. A. Balasko (1973). Persistence of several temperate grasses grown with alfalfa and harvested two, three, and four times annually at two stubble heights. Crop Sci. 13:553-556.

Smith, D., H. J. Lowe, A. M. Strommen, and G. N. Brooks (1954). Establishment of legumes as influenced by rate of sowing of the oat companion crop. Agronomy J. 46:449-451.

Smith, G. E. (1942). Sanborn Field: Fifty years of field experiments on crop rotations, manure and fertilizer. Missouri Agric. Expt. Sta. Bull. 458.6.

Smith, J. G. (1969). Some effects of crop background on populations of aphids and their natural enemies on brussels sprouts. Ann. Appl. Biol. 63:326-330.

Smith, Jr., S. R., J. H. Bouton, and C. S. Hoveland (1992). Persistence of alfalfa under continuous grazing in pure stands and in mixtures with tall fescue. Crop Sci. 32:1259-1264.

Smith, L. L., W. T. Federer, and D. Raghavarao (1974). A comparison of three techniques for eliciting truthful answers to sensitive questions. Proc. Soc. Stat. Sec., Amer. Stat. Assoc. pp. 447-452.

Smith, M. A., P. R. Carter, and A. A. Imholte (1992). Conventional vs. no-till corn following alfalfa/grass: timing of vegatative kill. Agronomy J. 84:780-786.

Smith, M. A. and R. W. Zobel (1990). Plant genetic interactions in alternative cropping systems: Consideration for breeding method. In Plant Breeding and Sustainable Agriculture (ed: D. A. Sleper. T. C. Barker, and P. J. Bramel-Cox), CSSA Spec. Pub. 18, ASA, Madison, pp. 57-81.

Smith, M. E. and C. A. Francis (1986). Breeding for multiple-cropping systems. In Breeding for Multiple Cropping Systems (ed: C. A. Francis). Macmillan, New York, pp. 219-249.

Smith, M. S, W. W. Frye, and J. J. Varco (1987). Legume winter cover crops. Adv. Soil Sci. 7:96-139.

Smith, N. (1985). Trees and food for a hungry world. Food Policy 10:82.

Smith, R. F. (1973). Management of the environment and the insect pest control. Proc. EAO Conf. Ecology in Relation to Plant Pest Control, Rome, pp. 3-17.

Smyth, A. J. and R. F. Mongomery (1962). Soils and land use of Central Western Nigeria. The Government Press of Western Nigeria.

Snaydon, R. W. (1971). An analysis of competition between plants of Trifolium repens population collected from contrasting soils. J. Appl. Ecol. 8:681-687.

Snaydon, R. W. (1979). A new technique for studying plant interaction. J. Appl. Ecol. 16:281-286.

Snaydon, R. W. and P. M. Harris (1979). Interactions below ground- the use of nutrients and water. Proc. Intl. Workshop on Intercropping, ICRISAT, Hyderbad, India.

Soemarwanto, O. (1982). Cultivation pattern research at 1980/1981 teak intercropping plantations (Agroforestry, Indonesia). Jutta Rimba, Jakarta, 8:11-13.

Soleri, D. and D. A. Cleveland (1988). Diversity and small-scale traditional agriculture. New Alchemy Inst. Issue 32, pages 9-10.

Sollenberger, L. E. and K. H. Quesenberry (1985). Factors affecting the establishment of aeschynomene in a Floralta limpograss sod. Soil Crop Sci. Soc. Fla. Proc. 44:141-146.

Sollenberger, L. E., W. C. Templeton, Jr., and R. R. Hill, Jr. (1984). Orchardgrass and perennial ryegrass with applied nitrogen and in mixtures with legumes: I. Total dry matter and nitrogen yields. II. Component contributions to dry matter and nitrogen harvests. Grass Forage Sci. 39:255-274. 
Solomon, T. R. and M. Flores (1994). Intercropping corn and frijol chinapopo (Phaseolus coccineus) : contributions of an indigenous practice to sustainable agriculture production in the highlands of Honduras (a diagnostic overview). Tegucigalpa MDC, Honduras : CIDICCO, 45 pp.

Sooksathan, I. (1976). A comparative growth analysis of intercrop and monoculture plantings of rice and corn. Ph.D. Thesis, Univ. Philippines.

Sooksathan, I. and R. R. Harwood (1976). A comparative growth analysis of intercrop and monoculture plants of rice and corn. Saturday Seminar, IRRI, Los Banos, Philippines.

Soria, J., R. Brazan, A. M. Pinchinat, et al. (1975). Investigacion sobre sistemas de production agricola para el pequeno agricultor del tropico. Turrialba 25:283-293.

Soundararajan, D. and S. P. Palaniappan (1971). Effect of intercropping on growth and yield components of redgram pigeonpeas. Indian J. Agric. Res. 13(3):127-132.

Southwood, T. R. E. and M. J. Way (1970). Ecological background to pest management. In Concepts of Pest Management. North Carolina State Univ., Raleigh, North Carolina. pp. 6-28.

Souza, E., J. R. Myers, and B. T. Scully (1993). Genotype by environment interaction in crop improvement. In Crop Improvement for Sustainable Agriculture (ed: M. B. Callaway and C. A. Francis), Univ. Nebraska Press, Lincoln and London, pp. 192-233.

Souza, F. B. F. de and M. J. B. de Andrade (1984). The influence of different populations of corn and beans under intercropping conditions (Brazil). Pesqui. Agropecu. Bras. 19:469-471.

Sparnanij, L. D. (1957). Mixed cropping in palm cultivation. J. W. Afr. Inst Oil. Palm Res. 2(7):244-264.

Spataru, P. (1982). A contribution to the-study of the natural food of Sarotherodon hybrids grown under conditions of polyculture, supplementary feed and intensive fertilization. Bamidgeh $Q$. Aquaculture Isr. Nir-David 34(4):144-157.

Spitters, C. J. T. (1979). Competition and its consequences to selection in barley breeding. Agric. Res. Rep. 893, Wageningen.

Spitters, C. J. T. (1983). An alternative approach to the analysis of mixed cropping experiments. 1. Estimation of competition effects. Neth. J. Agric. Sci. 31:1-11.

Spitters, C. J. T. (1983). An alternative approach to the analysis of experiments. 2. Marketable yield. Neth. J. Agric. Sci. 31:143-156.

Spitters, C. J. T. and J. P. van den Bergh (1982). Competition between crop and weeds: A system approach. In Biology and Ecology of Weeds (ed: W. Holzner and N. Numata). Dr. W. Junk Publ., The Hague, Netherlands, pp. 137-148.

Spitters, C. J. T. and R. Aerts (1983). Simulation of competition for light and water in crop-weed associations. Aspects Applied Biol. 4:467-483.

Spitters, C. J. T., M. J. Kropff, and W. de Groot (1989). Competition between maize and Echinochla crusgalli analysed by a hyperbolic regression model. Annals Applied Biol. 115:541-551.

Sprague, H. B. (1936). The value of winter green manure crops. New Jersy Agric. Expt. Sta. Bull. 609.

Spurling, A. T. (1973). Field trials with Canadian wonder beans in Malawi. Expl. Agric. 9:97-105.

Srinivasan, A. and I. P. S. Ahlawat (1984). Studies on planting pattern and phosphate fertilization of sole and mixed stands of pigeonpea. Indian J. Agron. 29:249-253.

Srinivasan, K. and G. K. Veeresh (1986). Economic analysis of a promising cultural practice in the control of moth pests of cabbage. Insect Sci. Appl. 7:559-563.

Srinivasan, K. and P. N. Krishna-Moorthy (1991). Indian mustard as a trap crop for management of major lepidopterous pests on cabbage. Trop. Pest Mgt. 37:26-32.

Srinivasan, K., P. N. Krishna-Moorthy, and R. N. Raviprasad (1994). African marigold as a trap for the management of the fruit borer Helicoverpa armigera on tomato. Intl. J. Pest Mgt. 40:56-63.

Srivastava, H. P. (1972). Multiple cropping programme - progess and problems. In Multiple Cropping, Proc. Symp., Harayana Agric. Univ., Hissar, India, pp. 335-342.

Srivastava, J. N. (1968). On a general class of designs for multiresponse experiments. Annals Math Statist. 39:1825-1843.

Srivastva, A. K., B. Verma, A. K. Singh, and S. Ram (1986). Role of intercropping in stabilising production under rainfed agriculture. In Soil Conservation in India (ed: R.K. Gupta and M. L. Khybri). Jugal Kishore, Dehra Dun, India, pp. 157-163.

Ssekabembe, C. K. (1985). Perspectives on hedgerow intercropping. Agroforestry Syst. 3:339-356. 
Ssekabembe, C. K. (1986). The importance of differences in maturity periods and stature in sorghum/finger millet intercrops. Trop. Agric. 63:289-292, 337.

Stahlman, P. W. and S. D. Miller (1990). Downy brome (Bromus tectorum) interference and economic thresholds in winter wheat (Triticum aestivum). Weed Sci. 38:224-228.

Stallings, J. H. (1926). The form of legume nitrogen assimilated by non-legumes when grown in association. Soil Sci. 21:253-276.

Stallman, H. R. and L. B. Best (1996). Bird use of an experimental strip intercropping system in northeast Iowa. J. Wildlife Mgt. 60:354-362.

Stallman, H. R. and L. B. Best (1996). Small-mammal use of an experimental strip intercropping system in northeastern Iowa. Amer. Midland Naturalist 135:266-273.

Staniforth, D. W. (1961). Response of corn hybrids to yellow foxtail competition. Weeds 9:132-136.

Stanley, S. A. and J. D. Nichols (1995). Terminalia amazonia interplanted with nitrogen fixing trees on a degraded pasture in Uvita de Osa, Costa Rica. Thailand Inst. Sci. Tech. Res., Nitrogen fixing tree research reports (NFTA), pp. 152-155.

Steel, W. M. (1972). Cowpea in Nigeria. Ph.D. Thesis, Univ. Reading, England.

Steel, W. M. and K. L. Mehra (1978). Structure, evolution and adaptation to farming systems and environments in Vigna. Paper, Intl. Legume Conf., Kew, England.

Steffins, G. L. and O. E. Street (1957). Effects of winter cover crops on growth, quality and nitrogen nutrition of Maryland tobacco. Univ. Maryland Agric. Expt. Sta. Bull. A-86.

Steiner, J. J. and J. P. Snelling (1994). Kura clover seed production when intercropped with wheat. Crop Sci. 34:1330-1335.

Steiner, J. L., J. R. Williams, and O. R. Jones (1987). Evaluation of the EPIC simulation model using a dryland wheat-sorghum-fallow crop rotation. Agronomy J. 79:732-738.

Steiner, K. G. (1982). Intercropping in tropical smallholder agriculture with special reference to West Africa. German Agency Tech. Coop (GTZ), Eschborn, FRG.

Steiner, K. G. (1984). Intercropping in Tropical Smallholder Agriculture With Special Reference to West Afica. 2. ed. Deutsche Gesellschaft Tech. Zusammenarbeit GTZ, Eschborn, 304 pp.

Steiner, K. G. (1985). Intercropping in tropical smallholder agriculture with special reference to West Africa. Deutsche Gesellschaft Tech. Zusammenarbeit, Eschborn, 347 pp.

Stelly, M. (1976). Multiple Cropping. ASA Spec Publ. no. 27, ASA, CSSA, and SSSA, Madison, WI.

Stern, V. M. (1969). Interplanting alfalfa in cotton to control Lugus bugs and other insect pests. Proc. Tall Timbers Conf. Ecology, Animal Control Habitat Management 1, pp. 55-69.

Stevens, W. E., J. R. Johnson, J. J. Varco, and J. Parkman (1992). Tillage and winter cover management effects on fruiting and yield of cotton. J. Prod. Agric. 5:570-575.

Stewart, D. A. and D. M. B. Chestnutt (1974). Some mathematical aspects of clover, grass, and fertilizer nitrogen relations. J. Agric. Sci. 82:331-342.

Stickler, F. C., W. D. Shrader, and I. J. Johnson (1958). Comparative value of legume and fertilizer nitrogen for corn production. Agronomy J. 50:157-160.

Stoa, T. E. and J. C. Zubriski (1969). Crop rotation, crop management and soil fertility studies on Fargo clay. North Dakota Res. Rep. 20.

Stoller, E. W. aand R. A. Myers (1989). Effects of shading and soybean Glycine max (L.) interference on Solanum ptycanthum (Dun.) (eastern black nightshade) growth and development. Weed Res. 29:307-316.

Stoop, W. A. (1978). Annual Report, ICRISAT Agronomy Program, Upper Volta (Summary), 1977. ICRISAT, Quagadougou, Upper Volta, $17 \mathrm{pp}$.

Stoop, W. A. (1986). Agronomic management of cereal/cowpea cropping systems for major toposequence land types in the West African savanna. Field Crops Res. 14:301-319.

Stricker, J. A., A. G. Matches, G. B. Thompson, et al. (1979). Cow-calf production on tall fescue-ladino clover pastures with and without nitrogen fertilization or creep feeding spring calves. J. Animal Sci. 43:13-16.

Stringer, W. C., A. Khalilian, D. J. Undersander, et al. (1994). Row spacing and nitrogen: Effect on alfalfa-bermudagrass yield and botanical composition. Agronomy J. 86:72-76.

Stringer, W. C., B. C. Morton, and B. W. Pinkerton (1996). Row spacing and nitrogen: Effect on alfalfabermudagrass quality components. Agronomy J. 88:573-577. 
Strout, B. A. (1975). Some definitional problems with 'multiple-crop diversification'. Phillipine Econ. J. 14(1/2):27.

Sturdy, D. (1939). Leguminous crops in native agricultural practice. E. Afr. Agric. For. J. 5:31-32.

Stute, J. K. and J. L. Posner (1993). Legume cover crop options for grain rotations in Wisconsin. Agronomy J. 85:1128-1132.

Stutzel, H. and R. L. Vanderlip (1988). Grain yield of intercropped sorghum and pearl millet as influenced by sorghum genotype and cropping pattern. Z. Acker Pflanzenbau 160:191-197.

Suarna, I. M. and T. Ogo (1983). The growth and yields of dent corn intercropped with three different planting densities of soybean (Glycine $\max$ L. Merr. var. Shirotae). Sci. Rep. Fac. Agric. Okayama Univ, Okayama, The University Issue 62, pp. 1-5.

Subbiah, K. K. and S. Kolandaiswamy (1980). Intercropping in banana annual crops. Madras Agric. J. Coimbatore 67(11):712-713.

Subedi, K. D. (1996). Effect of leaf stripping, de-tasselling and topping of maize on the yield of maize and relay intercropped finger millet. Expl. Agric. 32:57-61.

Subrahmanyam, K., S. R. Reddy, R. Veeraraghavaiah, et al. (1984). Studies on planting patterns in rice. Andhra Agric. J. 31:244-245.

Subramanian, V. B. and D. G. Rao (1988). Intercropping effects on yield components of dryland sorghum, pigeon pea and mung bean. Trop. Agric. 65:145-149.

Suckling, F. E. T. (1976). A 20-year study of pasture development through phosphate and legume - oversowing on North Island hill country of New Zealand. Proc. Intl. Symp., West Virginia Univ., Morgantown, pp. 367-380.

Suehiro, K. and H. Ogawa (1980). Competition between two annual herbs, Atriplex gmeline C. A. Mey and Chenopodium album L., in mixed cultures irrigated with seawater of various concentration. Oecologia 45:167-177.

Sui-Piao (1992). Kao ch'an kao hsiao chien tso t'ao chung chi shu / chu pien Sui Piao ; fu chu pien Sun Kuei-min, Chou Wei-fu. Ti 1 pan. SO Nan-ching : Chiang-su k'o hsueh chi shu ch'u pan she, 105 pp.

Sulc, R. M. and K. A. Albrecht (1996). Alfalfa establishment with diverse annual ryegrass cultivars. Agronomy J. 88:442-447.

Sulc, R. M., K. A. Albrecht, and M. D. Casler (1993). Ryegrass companion crops for alfalfa establishment: I. Forage yield and alfalfa suppression. Agronomy J. 85:67-74.

Sulc, R. M., K. A. Albrecht, and M. D. Casler (1993). Ryegrass companion crops for alfalfa extablishment: II. Forage quality in the seeding year. Agronomy J. 85:75-80.

Sullivan, P. G., D. J. Parrish, and J. M. Luna (1991). Cover crop contributions to N supply and water conservation in corn production. Amer. J. Altern. Agric. 6:106-113.

Sumarno, and W. R. Fehr (1980). Intergenotypic competition between determinate and indeterminate soybean cultivars in blends and alternate rows. Crop Sci. 20:251-254.

Sun, H. (1987). Organic farming: Growing plants the organic way. In Feeding a Billion: Frontiers of Chinese Agriculture (ed: Sylvan Wittwer et al.). Michigan State Univ. Press, East Lansing, pp. 111-125.

Sunthorn, B. (1988). Final report on relay and intercropping of legumes and cereals for highland. Chiang Mai, Thailand, The Faculty, 60 leaves.

Suresh, K. K. and R. S. Vinaya-Rai (1991). Studies on intercropping with silk cotton trees (Ceiba pentandra (L.) Gaertn.). Trop. Agric. 68:37-40.

Suryatna, E. S. (1976). Nutrient uptake, insect, disease, labor use, and productivity characteristics of selected traditional intercropping patterns which together affect their continued use by farmers. $\mathrm{Ph} . \mathrm{D}$. Thesis, Univ. Philippines, Los Banos College, Laguna, Philippines.

Suryatna, E. S. and R. R. Harwood (1976). Nutrient uptake of two traditional intercrop combinations and insect and disease incidence in three intercrop combinations. Saturday Seminar, IRRI, Los Banos, Philippines.

Sutherland, W. N., W. D. Shrader, and J. T. Pesek (1961). Efficiency of legume residue nitrogen and inorganic nitrogen in corn production. Agronomy J. 53:339-342.

Sutton, J. D. and D. B. Weaver (1989). Intergenotypaic competition between late-planted determinate and indeterminate soybean. Crop Sci. 29:1506-1510. 
Suwanarit, A., C. Suwannarat, and S. Chotchungmaneerat (1983). Effects of times and methods of Nfertilizer placement on yields and fertilizer utilization of maize-mung bean intercrops as indicated by 15 N. Kasetsart J. Natl. Sci. 17:27-33.

Suwanarit, A., V. Verasan, C. Suwannarat, and S. Chaochong (1984). Comparative water uses of maizemungbean intercrop, sole maize and sole mungbean. Kasetsart J. Natl. Sci. 18:117-121.

Sveshnikov, A. M. Summer and intercropping sowings of forage mixtures in the forest-steepe of Northern Kazakhstan. Vestn S-Kh Nauki Kaz. 10:59-62.

Swaminathan, M. S. (1970). New varieties for multiple cropping. Indian Farmer 20(7):9-13.

Swaminathan, M. S. (1981). Introducing nutritional considerations into agricultural and rural development. United Nations Univ., Tokyo. 3(3):30-36.

Swaminathan, M. S. and S. S. Bains (1972). Scientific multiple cropping. I. Mod. Agric. 3(2):9-12.

Swaminathan, M. S. and S. S. Bains (1972). Scientific multiple cropping. IV. Mod. Agric. 3(6):9-12.

Swift, J. F. (1982). Intercropping of two Leucaena spp. with sweetpotato: yield, growth rate and biomass. Taipei, Taiwan, Leucaena Res. Rep. 3: 52-53.

Swinkels, R. and S. Franzel (1997). Adoption potential of hedgerow intercropping in maize-based cropping systems in the highlands of western Kenya. 2. Economic and farmers' evaluation. Expl. Agric. 33:211-223.

Syarifuddin, A., Soeharno, and J. L. MacIntosh (1975). Multiple cropping in Indonesia. Proc. Cropping Systems -Workshop. IRRI, Los Banos, Philippines. pp. 33-56.

Syme, J. R. and P. M. Bremner (1968). Growth and yield of pure and mixed crops of oats and barley. J. Appl. Ecol. 5:659-674.

Symons, T. B. (1942). Accumulating soil nitrogen by manure and cover crops. Agron. Hort. Dept., Maryland Coop. Ext. Serv. Circ. 139.

Symth, T. J. and M. S. Cravo (1990). Critical phosphorous levels for corn and cowpea in a Brazillian Amazon Oxisol. Agronomy J. 82:309-312.

Symth, T. J. and M. S. Cravo (1990). Phosphorous management for continuous corn-cowpea production in a Brazillian Amazon Oxisol. Agronomy J. 82:305-309.

Ta, T. C. and M. A. Faris (1987). Effect of alfalfa proportions and clipping frequencies on timothy-alfalfa mixtures. II. Nitrogen fixation and transfer. Agronomy J. 79:820-824.

Ta, T. C. and M. A. Faris (1987). Effects of alfalfa proportions and clipping frequencies on timothyalfalfa mixtures. I. Competition and yield advantages. Agronomy J. 79:817-820.

Ta, T. C. and M. A. Faris (1987). Species variation in the fixation and transfer of $\mathrm{N}$ from legumes to associated grasses. Plant Soil 98:265-274.

Ta-Achmadiah (1983). Tanaman sela diantara jalur tanaman karet dilihat dari segi pertumbuhan tanaman karet dan hasil sampingan petani. SO Palembang : Univ. Sriwijaya, 20 leaves.

Tag, E. L. and M. Seed (1978). Effect of pH on the nature of competition between Eichhornia crassipes and Pistia stratiotes. J. Aquat. Plant Manage. 16:53-57.

Tajuddin, I. (1986). Integration of animals in rubber plantations. Agroforestry Syst. 4:55-66.

Takaya, T. and T. Honda (1983). Nihon Sakumosu Gakkai Kiji Jap. J. Crop Sci. Tokyo: Nihon Sakumotsu. Gakkai 52(3):377-378.

Tanaka. A. and K. Kawano (1966). Effect of mutual shading on dry matter production in the tropical rice plant. Plant Soil 24:128-144.

Tankou, C. M., B. Schaffer, S. K. Ohair, and C. A. Sanchez (1990). Nitrogen, shading duration, gas exchange, and growth of cassava. HortSci. 25:1293-1296.

Tanner, J. W., E. E. Gamble, and W. E. Tossel (1966). Determination of botanical composition of twocomponent forage mixtures. Can. J. Plant Sci. 40:225-234.

Tapadia, B. B. and V. M. Bhale (1983). Intercropping pulses and oilseeds in rabi sorghum in Maharashtra, India. J. Maharashtra Agric. Univ. Pune 8(3):225-226.

Tapadia, B. B., R. A. Katare, and V. M. Bhale (1983). Intercropping pulses and oilseeds in rabi sorghum in Maharashtra (India). J. Maharashtra Agric. Univ. 8:225-226.

Tarawali, S. A. (1995). Evaluation of Stylosanthes hamata (L.) Taub. accessions for livestock and crop enterprises in subhumid Nigeria. Aust. J. Expl. Agric. 35:375-379.

Tarawali,S. A. and M. Peters (1996). The potential contribution of selected forage legume pastures to cereal production in crop-livestock farming systems. J. Agric. Sci. 127:175-182. 
Tarhalkar, P. P. and M. V. Venugopalan (1995). Effect of organic recycling of fodder legumes in stabilizing productivity of rainfed cotton (Gossypium hirsutum L.) on marginal lands. Trop. Agric. 72:73-

Tarhalkar, P. P. and N. G. P. Rao (1975). Changing concepts and practices of intercropping systems. Indian Farmer 25:3-7.

Tarhalkar, P. P. and N. G. P. Rao (1978). Genotype density infractions and development of an optimum sorghum-pigeonpea intercropping system. Paper, Symp. on Intercropping of Pulses, Indian Agric. Res. Inst., New Delhi, Washington, D. C.

Tariah, N. M. and T. A. T. Wahua (1985). Effects of component populations on yields and land equivalent ratios of intercropped maize and cowpea. Field Crops Res. 12:81-89.

Taylor, B. R. (1986). Sesame agronomy in south-east Tanzania. II. Intercropping with sorghum. Expl. Agric. 22:253-261.

Taylor, R. W. and D. W. Allison (1983). Legume establishment in grass sods using minimum-tillage seeding techniques without herbicide application: Forage yield and quality. Agronomy J. 75:167172.

Taylor, T. A. (1976). Mixed cropping as an input in the management of crop pests in tropical Africa. Paper, $15^{\text {th }}$ Intl. Congress on Entomology, Washington, D. C.

Taylor, T. H., J. S. Foote, J. H. Snyder, et al. (1972). Legume seeding stands resulting from winter and spring sowings in Kentucky bluegrass (Poa pratensis L.) sod. Agronomy J. 64:535-538.

Taylor, T. H., E. M. Smith, and W. C. Templeton, Jr. (1969). Use of minimum tillage and herbicide for establishing legumes in Kentucky bluegrass (Poa pratensis L.). Agronomy J. 61:761-766.

Teasdale, J. R. and K. L. Deahl (1987). Performance of four tomato cultivars intercropped with snap beans. Hortsci. 22:668-669.

Teixeira Monteiro, A. A., C. Vieira, and C. C. de Silva (1981). Yields of twenty bean cultivars under two cropping systems. Annu. Rep. Bean Improv. Coop. 23:49-50.

Tejwani, K. G. (1987). Agroforestry practices and research in India. In Agroforestry: Realities, Possibilities, and Potentials (ed: H. L. Gholz). M. Nijhoff, Dordrecht, pp. 109-136.

Tekle-Haimanot, A. and E. V. Doku (1995). Comparison of Azolla mexicana and $\mathrm{N}$ and $\mathrm{P}$ fertilization on paddy taro (Colocasia esculenta) yield. Trop. Agric. 72:70-72.

Terman, G. L. (1949). Green manure crops and rotations for Maine potato soils. Maine Agric. Expt. Sta. Bull. 474.

Teser, M. B. (1957). Establishment of alfalfa in wide-row corn. Agronomy J. 49:63-68.

Tewari, G. P. and L. R. Schmid (1960). The productiona and botanical composition of alfalfa-grass combinations and the influence of the legume on the associated grass. Agronomy J. 52:267-269.

Thakur, D. R., K. K. Singh, and R. C. Thakur (1989). Effect of weed control and fertilizer levels on weed growth and grain yield of rainfed maize. Indian J. Agric. 34:50-52.

Thamburaj, S. and C. R. Muthukrishnan (1977). Studies on intercropping in tapioca Manihot esculentacrantz). Madras Agric. J. Coimbatore 63(3):198-199.

Thatcher, L. E. (1925). The soybean in Ohio. Ohio Agric. Expt. Sta. Bull. 384.68 pp.

Theunisen, J. and H. den Ouden (1980). Effects of intercropping with Spergula arvensis on pests of Brussels sprouts. Entomol. Expl. Appl. 27( 3):260-268 .

Theunissen, J. (1994). Intercropping in field vegetable crops: pest management by agrosystem diversification-an overview. Pesticide Sci. 42:65-68.

Theunissen, J., C. J. H. Booij, and L. A. P. Lotz (1995). Effects of intercropping white cabbage with clovers on pest infestation and yield. Entomologia Expt. Applicata 74:7-16.

Theunissen, J. and G. Schelling (1996). Pest and disease management by intercropping: suppression of thrips and rust in leek. Intl. J. Pest Mgt. 42:227-234.

Thilsted, E. and D. S. Murray (1980). Effect of wheat straw on weed control in no-till soybeans. Proc. South. Weed Sci. Soc., p.42.

Thomas, G. V. and M. V. Shantaram (1984). In situ cultivation and incorporation of green manure legumes in cocnut basins. Plant Soil 80:373-380.

Thomas, G. W., R. L. Blevins, R. E. Phillips, and M. A. McMahon (1973). Effect of a killed sod mulch on nitrate movement and corn yield. Agronomy J. 65:736-739. 
Thomas, J. B. and G. B. Schaalje (1997). Winter survival and competition in a mixture of winter wheat cultivars. Crop Sci. 37:732-738.

Thomas, P. E. L. and J. C. S. Allison (1975). Competiton between maize and Rottboellia exaltata. J. Agric. Sci. (Camb.) 84:305-312.

Thomas, P. K., C. R. M. Kumar, and M. Prabhakar (1982). Intercropping cassava with French beans (India). Indian Farming 32:5.

Thompson, D. J. and D. G. Stout (1992). Influence of annual ryegrass and barley seeding rates on intercrop forage yield and quality. Can. J. Plant Sci. 72:1199-1206.

Thompson, D. J., D. G. Stout, and T. Moore (1992). Forage production by four annual cropping sequeces emphasizing barley under irrigation in southern interior British Columbia. Can. J. Plant Sci. 72:181-185.

Thomson, R. T. and P. L. Nuthall (1976). Use of crop residues of wheat, barley, ryegrass, and peas for beef production on Canterbury mixed cropping farms feed. N. Z. Agric. Sci. 10(2):58-61.

Thonney, M. L., D. J. Duhaime, T. L. Jenkins, and C. A. Ruppel (1980). Microbial and chemical additives in alfalfa-timothy silage. J. Dairy Sci. 63:587-593.

Thurlow, D. L. and G. A. Buchanan (1972). Competition of sicklepod with soybeans. Weed Sci. 20:379384.

Tidwell, E. K., K. D. Johnson, and J. H. Cherney (1986). Indirect estimation of wheat-hairy vetch ratios in mixed stands. Agronomy J. 78:344-346.

Tiessen, H. (1988). Evaluation of soil $\mathrm{N}$ under intercropping and crop rotations on a highly heterogeneous soil. Commun. Soil Sci. Plant Anal. 19:461-470.

Tingey, W. M. and W. J. Lamont, Jr. (1988). Insect abundance in field beans altered by intercropping. Bull. Entomol. Res. 78:527-535.

Tiwana, M. S. and K. P. Puri (1979). Intercropping of napier bajra pearlmillet hybrid (NB-21) with winter forage crops. Indian J. Dairy Sci. 32(4):419-423.

Tiwana, M. S. and S. S. Bains (1976). Studies on the intercropping of Napier Pennisetum purpureum Bajra Pennisetum typhoides hybrids with Lucerne. J. Res. Punjab Agric. Univ. 13:48-51.

Tiwari, B. P., S. R. Maley, and S. S. Tower (1973). Mixed cropping of soybean with jowar and maize. J. Nkvv. Res. J. 7:4-8.

Tiwari, D. K., J. A. Jackobs, and S. G. Carmer (1963). Statistical techniques for correcting botanical and floristic estimates in pasture research. Agronomy J. 55:226-228.

Tiwari, K. M. (1970). Interim results of intercropping of miscellaneous tree species with main crop of Taungya Plantations to increase the productivity. Indian Forest 96(9):650-653.

Tobita, S., O. Ito, R. Matsunaga, et al. (1994). Field evaluation of nitrogen fixation and use of nitrogen fertilizer by sorghum/pigeonpea intercropping on an Alfisol in the Indian semi-arid tropics. Biol. Fertility Soils 17:241-248.

Tofinga, M. P., R. Paolini, and R. W. Snaydon (1993). A study of root and shoot interactions between cereals and peas in mixtures. J. Agric. Sci. 120:13-24.

Toko, M., J. S. Yaninek, R. J. O'Neil (1996). Response of Mononychellus tanajoa (Acaria: Tetranychidae) to cropping systems, cultivars, and pest interventions. Environ. Entomology 25:237-249.

Tollenaar, M., A. A. Dibo, A. Aguilera, S. F. Weise, and C. J. Swanton (1994). Integrated pest management. Agronomy J. 86:591-595.

Tollenaar, M., M. Mihajlovic, and T. J. Vyn (1992). Annual phytomass production of a rye-corn doublecropping system in Ontario. Agronomy J. 84:963-967.

Tollenaar, M., M. Mihajlovic, and T. J. Vyn (1993). Corn growth following cover crops: Influence of cereal cultivar, cereal removal, and nitrogen rate. Agronomy J. 85:251-255.

Tollenaar, M., S. P. Nissanka, A. Aguilera, S. F. Weise, and C. J. Swanton (1994). Effect of weed interference and soil nitrogen on four maize hybrids. Agronomy J. 86:596-601.

Tomar, J. S., A. F. MacKenzie, G. H. Mehuys, and I. Alli (1988). Corn growth with foliar nitrogen, soilapplied nitrogen, and legume intercrops. Agronomy J. 80:802-807.

Tomar, S. S., R. K. Sharma, and K. N. Namdeo (1984). Relative efficiency of multi-intercrop system in pigeonpea under rainfed condition. Indian J. Agron. 29:475-579. 
Tomer, P. S. and S. L. Saini (1979). Crop geometry and intercropping in rainfed pearlmillet. Indian J. Agric. Sci. 49(8):627-633.

Tomming, H. (1970). Mathematical description of net photosynthesis and adaptation processes in the photosynthetic apparatus of plant communities. In Prediction and Measurement of Photosynthetic Productivity. Proc. IBP/PP Tech. Meeting, Trebon, Czecholovakia, pp . 103-113.

Tomming, K. H. G. (1972). Competition between two plant species for photosynthetically active radiation. Ekologiya 4:63-72. (In Russian)

Tonhasca, Jr., A. (1993). Carabid beetle assemblage under diversified agroecosystems. Entomologia Expt. Applicata 68:279-285.

Tonhasca, Jr., A. (1993). Effects of agroecosystem diversification on natural enemies of soybea herbivores. Entomologia Expt. Applicata 69:83-90.

Tonhasca, Jr., A. and B. R. Stinner (1991). Effects of strip intercropping and no-tillage on some pest and beneficial invertebrates of corn in Ohio. Environ. Entomol. 20:1251-1258.

Tonhasca, Jr., A., and D. N. Byrne (1994). The effects of crop diversification on herbivorous insects: a meta-analysis approach. Ecol. Entomology 19:239-244.

Torbert, H. A., D. W. Reeves, and R. L. Mulvaney (1996). Winter legume cover crop benefits to corn: Rotation vs. fixed-nitrogen effects. Agronomy J. 88:527-535.

Torres, R. O., R. D. Magbanua, and D. P. Garrity (1989). The potential of cowpeas in acid upland cropping systems. Philippine J. Crop Sci. 13:91-98.

Touchton, J. T. and J. W. Johnson (1982). Soybean tillage and planting method effects on yield of doublecropped wheat and soybeans. Agronomy J. 74:57-59.

Touchton, J. T. and T- Whitwell (1984). Planting corn into strip killed clover. Proc. Annual Southeast NoTillage Systems Conf., Alabama Expt. Sta., Auburn Univ., Headland, AL, pp. 25-26.

Touchton, J. T., D. H. Reckert, R. H. Walker, and C. E. Snipes (1984). Winter legumes as a nitrigen source for no-tillage cotton. Soil Tillage Res. 4:391-401.

Touchton, J. T., W. A. Gardner, W. L. Hargrove, and R. R. Duncan (1982). Reseeding crimson clover as a N source for no-tillage grain sorghum production. Agronomy J. 74:283-287.

Touchton, J. T., W. L. Hargrove, R. R. Sharpe, and F. C. Boswell (1982). Time, rate and method of phosphorus application for continuous double-cropped wheat and soybeans. Soil Sci. Soc. Amer. J. 46:861-864.

Townley-Smith, L., A. E. Slinkard, L. D. Bailey, et al. (1993). Productivity, water use and nitrogenfixation of annual-legume green-manure crops in the Dark Brown soil zone of Saskatchewan. Can. J. Plant Sci. 73:137-148.

Townsend, C. E., H. Kenno, and M. A. Brick (1990). Compatibility of cicer milkvetch in mixtures of cool-season grasses. Agronomy J. 82:262-266.

Tremmel, D. C. and K. M. Peterson (1983). Competitive subordination of a Piedmont old field successional dominant by an introduced species. Amer. J. Bot. 70(8):1125-1132.

Trenbath, B. R. (1975). Diversity of be damned? Ecologist 5(3):76-83.

Trenbath, B. R. (1972). The productivity of varietal mixtures of wheat. Ph.D. Thesis, Univ. Adelaide, Australia.

Trenbath, B. R. (1974). Application of a growth model to problems of the productivity and stability of mixed stands. Proc. 12th Intl. Grassland Congress, Moscow, pp. 546-558.

Trenbath, B. R. (1974). Biomass productivity of mixtures. Adv. Agron. 26:177-120.

Trenbath, B. R. (1974). Models and interpretation of mixture experiments. In Plant Relations and Pasture (ed: J. R. Wilson), pp.145-162.

Trenbath, B. R. (1975). Neighbour effects in genus Avena. III. J. Appl. Ecol. 12:189-200.

Trenbath, B. R. (1976). Plant interactions in mixed plant communities. In Multiple Cropping (ed: R. I. Papendick et al.). ASA Spec. Publ. 50, ASA, CSSA, and SSSA, Madison, WI, pp. 129-169.

Trenbath, B. R. (1978). Models and the interpretation of mixture experiments. In Plant Relations in Pastures (ed: J. R. Wilson). CSIRO, Melbourne, Australia, pp. 145-162.

Trenbath, B. R. (1983). The dynamic properties of mixed crops. In Frontiers of Research in Agriculture: Proc. (ed: S.K. Roy), Calcutta, pages 265-286.

Trenbath, B. R. (1986). Resource use by intercrops. In Multiple Cropping Systems (ed: C. A. Francis). Macmillan, New York, pp. 57-82. 
Trenbath, B. R. and J. F. Angus (1975). Leaf inclination and crop production. Field Crop Abs. 5:231-244.

Trenbath, B. R., P. R. Hartley, and D. K. MacPherson (1977). Plant distribution and individual plant photosynthesis. $4^{\text {th }}$ Intl. Congress on Photosynthesis. Abstract U. K. Sci. Committee. pp. 384-385.

Tripathi, B. and C. M. Singh (1983). Weed and fertility management using maize/soyabean intercropping in the north-western Himalayas (India). Trop. Pest Mgt. 29:267-270.

Tripathi, B. R., P. J. Psychas, K. K. Atta, and N. Sanginga (1992). The AFNETA alley farming training manual. Alley Farming Network Trop. Africa, Ibadan, $2 \mathrm{v}$.

Triplett, Jr., G. B. (1962). Intercrops in corn and soybean cropping systems. Agronomy J. 54:106-109.

Triplett, Jr., G. B. (1978). Weed control for doublecrop soybeans planted with no-tillage method following small grain harvest. Agronomy J. 70:577-581.

Triplett, Jr., G. B. and J. V. Mannering (1978). Crop residue management in crop rotation and multiple cropping system. In Crop Residue Management Systems (ed: W. R. Oschwald). Spec. Publ. 31, ASA, CSSA, and SSSA, Madison, WI, pp. 187-206.

Triplett, Jr., G. B., F. Haghiri, and D. M. Van Doren, Jr. (1980). Legumes supply nitrogen for no-tillage corn. Agrichem. Age. 24:48A.

Triplett, Jr., G. J., J. Beuerlein, and M. Kroetz (1976). Relay cropping not reliable. Crops and Soils 29(2):8-10.

Tsivindo, A. Z. and A. G. Pokusaeva (1978). Vestn S-kh Nauki Kaz. Alma-Ata. No. 5. pp. 55-58.

Tukahirwa, E. M. and T. H. Coaker (1982). Effect of mixed cropping on some insect pests of brassicas; Brevicoryne brassicae infestations and influences on epigeal predators and the disturbance of oviposition behaviour in Delia brassicae. Entomol. Expl. Appl. 32(2): 129-140.

Turkington, R, P. B. Cavers, and L. W. Aarssen (1977). Neighbour relationships in grass-legume communities: I. Interspecific contacts in four grassland communitiies near London, Ontario. Can. J. Bot. 55:2701-2711.

Turkington, R. and P. B. Cavers (1979). Neighbour relationships in grass-legume communities: III. Development of pattern and association in artificial communities. Can. J. Bot. 57L2704-2710.

Twidwell, E. K., K. D. Johnson, and J. H. Cherney (1985). Winter small grains and hairy vetch as a forage crop. Proc. Forage Grassl. Conf., Amer. Forage Grassl. Council, Lexington, KY, pp. 84-88.

Tyler, D. D., B. N. Duck, J. G. Graveel, and J. F. Bowen (1987). Estimating response curves of legume nitrogen contribution to no-till corn. In The Role of Legumes In Conservation Tillage Systems (ed: J. F. Power). Proc. Natl. Conf., Soil Conserv. Soc. Amer., Ankeny, Iowa, pp.50-51.

Umat, D. S. and S. L. Deshpande (1982). Studies in intercropping of sorghum with redgram Cajunus cajun pigeonpeas. Sorghum Improvement Conf. North America. Sorghum Newsl. 25:50.

Umrani, N. K. and K. S. Pharande (1980). Studies on the intercropping in rabi sorghum J. Maharashtra Agric. Univ. Pune 4(3):311.

Umrani, N. K., R. B. Patil, and H. K. Pawar (1984). Studies on profit potentials of different intercropping systems with turmeric. Indian J. Agron. 29:383-385.

Umrani, N. K., S. H. Shinde, and P. M. Dhonde (1984). Studies on intercropping of pulses in kharif sorghum. Indian J. Agron. 29:27-30.

Umrani, N. K., S. H. Shinde, and P. W. Dhonde (1984). Studies on fertilizer application in intercropping of sorghum and groundnut (Peanut, Arachis hypogaea, India). J. Maharashtra Agric. Univ. 9:5152.

Umunna, N. N., P. O. Osuji, H. Khalili, et al. (1995). Comparative feeding value of forages from two cereal-legume based cropping systems for beef production from crossbred (Bos taurus $\times$ Bos indicus) steers and subsequent performance of underfed and realimented steers. Animal Sci. 61:3542.

Unamma, R. P. A. and L. S. O. Ene (1984). Weed interference in cassava aize intercrop in the rain forest of Nigeria. In Tropical Root Crops: Production and Uses in Africa (ed: E.R. Terry. et al.), Proc. $2^{\text {nd }}$ Triennial Symp. Intl. Soc. Trop. Root Crops, Douala, Cameroon, pp. 59-62.

Unamma, R. P. A., L. S. O. Ene, S. O. Odurukwe, and T. Enyinnia (1986). Integrated weed management for cassava intercropped with maize. Weed Res. 26:9-17.

Unnithan, G. C. and K. N. Saxena (1990). Diversion of oviposition by Atherigona soccata (Diptera: Muscidae) to nonhost maize with sorghum seedling extract. Environ. Entomol. 19:1432-1437. 
Usenbo, E. I. (1976). Approaches to integrated control of cotton pests in mid-western state of Nigeria. Ph.D. Thesis, Univ. London.

Usenbo, E. I. (1977). Effect of mixed cropping diversity on the abundance of predators of cotton pest spiders, Chilomnes lunata, Platynaspis ferrugnea. Niger J. Plant Prot. 3:139-151.

Utomo, M. (1986). Role of cover crops in no-tillage and conventional tillage corn production. Ph.D. Thesis, Univ. Kentucky, Lexington.

Utomo, M., W. W. Frye, and R. L. Blevins. (1990). Sustaining soil nitrigen for corn using hairy vetch cover crop. Agronomy J. 82:979-983.

Uvah, I. I. I. and T. H. Coaker (1984). Effect of mixed cropping on some insect pests of carrots and onions. Entomol. Expl. Appl. 36:159-167.

Uzozie, I. C. (1971). Patterns of crop combination in the three eastern states of Nigeria. J. Tropic. Geogr. 33:62-67.

Vacchani, M. V. and K. S. Murty (1964). Green manuring for rice. Central Rice Res. Inst. Bull. no. 4, Cuttack, India.

Vaile, R. S. (1918). Intercropping of young irrigated orchards. Agric. Expt. Sta., Univ. California, 11 pp.

Valenti, S. A. and G. A. Wicks (1992). Influence of nitrogen rates and wheat (Triticum aestivum) cultivars on weed control. Weed Sci. 40:115-121.

Valentim, J. F., O. C. Ruelke, and G. M. Prine (1987). Fertilizer versus legume nitrogen for tropical grass-legume associations. Proc. Forage Grassl. Conf., Springfield, IL, pp. 185-190.

Vallis, I. (1978). Nitrogen relationships in grass-legume mixtures. In Plant Relations in Pastures (ed: J. R. Wilson). CSIRO, Melbourne, pp. 190-201.

Vallis, I., E. F. Henzell, and T. R. Evans (1977). Uptake of soil nitrogen by legumes in mixed swards. Aust. J. Agric. Res. 28:413-425.

van Andel, J. and R. Dueck (1982). The importance of the physical pattern of plant species in replacement series. Oikos 39:59-62.

Van de Goor, G. A. W. (1954). The value of some leguminous plants as green manures in comparison with Crotalaria juncea. Neth. J. Agric. Sci. 2:37-43.

van den Berg, J. P. (1968). An analysis of yields of grasses in mixed and pure stands. Versl. Landbouwkd. Onderz 714:155-182.

Van den Bergh, J. P. (1968). An analysis of yields of grasses in mixed and pure stands. Agric. Res. Rep., Centre Agric., Wageningen, Publ. No. 714.

Van den Bergh, P. J. and W. T. Elberse (1962). Competition between Lolium perenne amd Anthoxanthum odoratum L. at two levels of phosphate and potash. J. Ecol. 50:87-95.

van der Paauw, F. (1962). Periodic fluctuations of soil fertility, crop yields and of responses to fertilization effected by alternating periods of low and high rainfall. Plant Soil 17:155-182.

Van Doren, Jr., D. M., G. B. Triplett, Jr., and J. E. Henry (1976). Influence of long term tillage, crop rotation, and soil type combinations on corn yield. Soil Soc. Amer. J.40:100-105.

Van Doren, Jr., D. M., G. B. Triplett, Jr., and J. E. Henry (1977). Influence of long-term tillage and crop rotation combinations on crop yields and selected soil parameters for an Aeric Ochraqualf soil. Res. Bull. 1091, Ohio Agric. Res. Development Ctr., Wooster.

Van Doren, Jr., D. M., W. C. Moldenhauer, and G. B. Triplett, Jr. (1984). Influence of long-term tillage and crop rotations on water erosion. Soil Sci. Soc. Amer. J. 40:636-640.

van Emden, H. F. (1977). Insect-pest management in multiple cropping systems - a strategy. Symp. Cropping Systems Res. Dev. Asian Rice Farmer, IRRI, Los Banos, Philippines, pp. 325-343.

van Emden, H. F. and G. F. Williams (1974). Insect diversity and stability in agroecosystems. Ann. Rev. Ento. 19:455-475.

Van Evert, F. K. and G. S. Campbell (1994). CropSyst: A collection of object-oriented simulation models of agricultural systems. Agronomy J. 86:325-331.

Van Heemst, H. D. J. (1985). The influence of weed competition on crop yield. Agric. Systems 18:81-95.

van Hoof, W. C. H. (1987). Mixed cropping of groundnuts and maize in East Java. Landbouwuniversiteit te Wageningen, $156 \mathrm{pp}$.

Van Kessel, C. and J. P. Roskoski (1988). Row spacing effects in $\mathrm{N}_{2}$-fixation, $\mathrm{N}$-yield and soil $\mathrm{N}$ uptake of intercropped cowpea and maize. Plant Soil 111:17-23. 
Van Keuren, R. W. amd W. W. Heinemann (1958). A comparison of grass-legume mixtures and grass under irrigation for yearling steers. Agronomy J. 50:85-88.

Van Keuren, R. W. and G. B. Triplett (1970). Seeding legumes into established swards. Proc. 9th Intl. Grassl. Congress, pp. 131-134.

Van Keuren, R. W. and H. L. Ahlgren (1957). A statistical study of several methods used in determining botanical composition of a sward: I. A study of established pastures. Agronomy J. 49:532-536.

Van Loon, C. D. and G. J. Bollen (1988). Effects of Crop Rotation on Potato Production in the Temperate Zones. Kliewer Academic Press, Dordrecht, Netherlands.

Van-Sambeek, J. W. (1985). Intercropping black walnut. Annu. Rep. North. Nut Grow. Assoc., The Assoc.. Issue 76 ${ }^{\text {th }}$, pp. 157-162.

Van-Santen, E. (1995). Intercropping small grains and lupin for sustainable on-farm utilization. Sustainable Agric. Res. Education (SARE) Res. Proj. Southern Region, 15 pp.

Vander Vorst, P. B., G. A. Wicks, and O. C. Burnside (1983). Weed control in a winter wheat-cornecofarming rotation. Agronomy J. 75:507-511.

Vander-Zaag, P. (1987). Developments in potato production techniques in Asia. Acta Hort. Issue 213, pp.

Vandermeer, J. (1981). The interference production principle: an ecological theory for agricultural intercropping. Q. Rev. Biol. 56(1):361-364.

Vandermeer, J. (1984). The interpretation and design of intercrop systems involving environmental modification by one of the components: a theoretical framework. Biol. Agric. Hort. 2:135-156.

Vandermeer, J. (1986). A computer-based technique for rapidly screening intercropping designs. Expl. Agric. 22:215-232.

Vandermeer, J. (1989). The Ecology of Intercropping. Cambridge Univ. Press, Cambridge.

Vandermeer, J. and B. Schultz (1990). Variability, stability, and risk in intercropping: some theoretical explorations. Ecol. Stud. Anal. Synth. 78:205-229.

Vandermeer, J., R. Ambrose, M. Hansen, et al. (1984). An ecologically-based approach to the design of intercrop agroecosystems: An intercropping system of soybeans and tomatoes in southern Michigan. Ecol. Modelling 25:121-150.

Vanotti, M. B. and L. G. Bundy (1995). Soybean effects on soil nitrogen availability in crop rotations. Agronomy J. 87:676-680.

Varco, J. J., J. H. Grove, W. W. Frye, and M. S. Smith (1991). Nitrogen availability from alfalfa suppressed or killed for no-till production. Commun. Soil Sci. Plant Anal. 22:1527-1535.

Varco, J. J., W. W. Frye, M. S. Smith, and C. T. MacKown (1989). Tillage effects on nitrogen recovery by corn from a nitrogen-15 labeled legume cover crop. Soil Sci. Soc. Amer. J. 53:822-827.

Vargo, A. M. (1991). Insect pests of taro (Colocasia esculenta) and their biological controls in American Samoa. Res. Ext. Ser. Univ. Hawaii, pp. 161-164.

Varma, M. P. and M. S. Subba Rao Kanke (1969). Selection of intercrops for cotton in India. Expl. Agric. 223-230.

Varshney, J. G. (1985). Intercrop urid with maize in Meghalaya. Indian Farming 35:32.

Varvel, G. E. (1994). Monoculture and rotation system effects on percipitation use efficiency of corn. Agronomy J. 86: 204-208.

Varvel, G. E. (1994). Rotation and nitrogen fertilization effects on changes in soil carbon and nitrogen. Agronomy J. 86:310-325.

Varvel, G. E. and T. A. Peterson (1990). Nitrogen fertilizer recovery by corn in monoculture and rotation systems. Agronomy J. 82:935-938.

Varvel, G. E. and T. A. Peterson (1990). Residual soil nitrogen as affected by continuous, two-year, and four-year crop rotation systems. Agronomy J. 82:958-962.

Varvel, G. E. and T. A. Peterson (1991). Nitrogen fertilizer recovery by grain sorghum in moncultures and rotation systems. Agronomy J. 83:617-622.

Varvel, G. E., and T. A. Peterson (1992). Nitrogen fertilizer recovery by soybean in monoculture and rotation systems. Agronomy J. 84:215-218.

Vaz, C. R. de, K. P. U. de Silva, and L. H. P. Gunaratna (1982). Agronomic and economic studies of cassava legume intercropping systems. Trop. Agric. 138:111-116. 
Venugopal, M. S. and S. Palanippan (1976). Influence of intercropping in sorghum on the incidence of sorghum shootfly Atherigona varia Soccata, cultural control M. Madras Agric. J. Coimbatore 63(8/10): 572-573.

Vergara, N. T. (1985). A primer. Unasylva, FAO UN 37:22-28.

Vergara, N. T. (1987). Agroforestry: a sustainable land use for fragile ecosystems in the humid tropics. In Agroforestry: Realities, Possibilities, and Potentials (ed: H. L. Gholz). M. Nijhoff, Dordrecht, pp. 7-19.

Verinumbe, I. and D. U. U. Okali (1985). The influence of coppiced teak (Tectona grandis L.F.) regrowth and roots on intercropped maize (Zea mays L.). Agroforestry Syst. 3:381-386.

Verma, D. P. S. (1990). Agroforestry practices of Gujarat state. Intl. Tree Crops J. 6:17-30.

Verma, H. N. and M. Singh (1981). Intercropping of raya in rainfed area with a wheat and bean mixture. India. Prog. Farm. 18(4):7.

Verma, R. S. and R. K. Tewari (1981). Studies on intercropping of spices and tobacco with autumn sugarcane. Indian Sugar 31(7):451-456.

Verma, R. S., R. S. Chauhan, and R. N. Singh (1985). Studies on row arrangement and population densities of potato cultivars in a sugarcane and potato intercropping system in north central India. Expl. Agric. 21:321-327.

Verma, S. K. and N. L. Joshi (1984). Infestation by Microcerotermes tenuignathus Holmgren (Isoptera: Termitidae: Amitermitinae) in some kharif crops. Ann. Arid Zone 23:131-133.

Verma, S. R., A. M. Chauhan, and H. S. Kalkat (1977). Multicrop seed drill-cum planter. Agric. Eng. Today 1(11):6-8.

Vest, G. (1971). Nitrogen increases in a non-nodulating soybean genotype grown with nodulating genotypes. Agronomy J. 63:356-359.

Viegas, P., E. S. Freire, and C. G. Fraga (1960). Adubacao do milho XIV. Ensaios com mucuna intercalada e adubos minerali. Bragantia 19:909-941.

Vieira, C. and J. M. Chagas (1982). Milho e feijao em cultivo consorciado. Ind. Agropecu. Empresa Pesqui Agropecu. Minas Gerais 8(90):13-15.

Vieira, C., H. Aidar, and R. F. Vieira (1975). Populacaes de plantas de milho e de feijao, no sistema de cultura consorciada, utilizadas na Zona da Mata de Minas Gerais. Rev. Ceres 22(122):286-290.

Vieira, C., M. A. P. Ramalho, and J. M. Chagas (1982). Maize and beans in associated cropping (Intercropping, yields, Minas Gerais State, Brazil). Inf. Agropecu. Empresa Pesqui. Agropecu. Minas Gerais 8:13-15.

Vieira, N. R. D.(1995). Green manuring of papaya trees. Acta Hort.Sept. pp. 117-119.

Vieira, S. A. and F. L. da C. Gastal (1980). Avaliacao do cultivo de milho e feijao nos sisemas exclusivo e consorciado. Pesqui Agropecu. Bras. 15:19-26

Villanueva, M. R. and E. Abenoja (1984). Adaptability of taro in the upland under monoculture, crop rotation, and intercropping systems in the Philippines. In Edible Aroids (ed: S. Chandra), pp. 3744.

Villanueva, M. R., J. R. Pardales, Jr., and E. A. Abenoja (1983). Performance of taro in the upland as affected by fertilizer application and population density under different production systems (Colocasia esculenta, in monoculture, rotation cropping or intercropping). Philipp. J. Crop Sci. 8:17-22.

Vincent, J. M. (196S). Environmental factors in the fixation of nitrogen by legumes. In Soil Nitrogen (ed: W. V. Bartholomew and F. E. Clark). ASA, Madison, WI, pp. 384-435.

Vine, P. N., O. B. Ajayi, D. M. Mitchozounou, et al. (1984). Soil-conserving techniques in cassava and yam production. In Tropical Root Crops: Production and Uses in Africa (ed: E.R. Terry. et al.), Proc. $2^{\text {nd }}$ Triennial Symp. Intl. Soc. Trop. Root Crops, Douala, Cameroon, pp. 67-70.

Von Rotenham, D. (1968). Cash cropping in Sukumaland. In Smallholder Farming and Smallholder Development in Tanzania (ed: H. Ruthenberg). African Studies No. 24, IFO Inst. Economic Studies, Munich, pp. 87-135.

Vorasoot, N. (1983). Root growth in intercropped pearl millet and groundnut. Thai. J. Agric. Sci. 16:279285.

Vos, J. et al. (1989). Effects of Crop Rotation on Potato Production in the Temperate Zones. Kluwer Acad. Publ., Dordrecht, Netherlands. 
Voss, R. D. and W, D. Shrader (1984). Rotation effects and legume sources of nitrogen for corn. In Organic Farming: Current technology and its Role in Sustainable Agriculture. ASA, CSSA, and SSSA, Madison, WI.

Voss, R. D. and W. D. Shrader (1979). Crop rotations: Effects on yields and response to nitrogen. Iowa State Univ. Coop. Ext. Service PM-9055.

Vrabel, T. E. (1981). The use of legumes as living mulch crops with sweet corn (Zea mays L.) - feasibility studies. M. S. Thesis, Cornell Univ., Ithaca, NY.

Vrabel, T., P. L. Minotti, and R. D. Sweet (1980). Seeded legumes as living mulches in sweet corn. Proc. N. Central Weed Sci. Soc., 29:170-175.

Waddington, J. (1992). A comparison of drills for direct seeding alfalfa into established grasslands. J. Range Mgt. 45:483-487.

Waddington, J. and S. Bittman (1984). Establishment and subsequent productivity of bromegrass and alfalfa seeded with an Argentine rapeseed companion crop in northeastern Saskatchewan. Can. J. Plant Sci. 64:303-308.

Waddington, S. R., A. F. E. Palmer, and O. T. Edje (1990). Research methods for cereal/legume intercropping. Proc. Workshop Res. Methods Cereal/Legume Intercropping Eastern Southern Africa, CIMMYT, $250 \mathrm{pp}$.

Wade, M. K. and P. A. Sanchez (1975). Multiple cropping. Agronomic-Economic Res. Tropical Soils Annual Rep. 1974, N. C. State Univ., Raleigh, pp. 52-60.

Wade, M. K. and P. A. Sanchez (1976). Liming monoculture and intercrop systems. Tropical Soils Res. Program Annual Report 1975, N. C. State Univ., Raleigh, pp. 152-166.

Wade, M. K. and P. A. Sanchez (1976). Multiple cropping experiment. Tropical Soils Res. Program Annual Report 1975, N. C. State Univ., Raleigh, pp. 137-152.

Wade, M. K. and P. A. Sanchez (1983). Mulching and green manure applications for continuous crop production in the Amazon Basin. Agronomy J. 75:39-45.

Wade, M. K. and P. A. Sanchez (1984). Productive potential of an annual intercropping scheme in the Amazon. Field Crops Res. 9:253-263.

Wagger, M. G. (1989). Cover crop management and nitrogen rate in relation to growth and yield of no-till corn. Agronomy J. 81:533-538.

Wagger, M. G. and D. B. Mengel (1988). The role of nonleguminous cover crops in the efficient use of water and nitrogen. In Cropping Strategies For Efficient Use of Wate and Nitrogen (ed: W. L. Hargrove et al.). ASA Spec. Publ. no. 51, ASA, Madison, WI, pp. 115-127.

Wagger, M: G. and H. P. Denton (1989). Tillage effects on grain yields in a wheat, double-crop soybean, and corn rotation. Agronomy J. 81:493-498.

Waghmare, A. B. and S. P. Singh (1982). Crop compatibility and spatial arrangement in sorghum-based intercropping systems. J. Agric. Sci. 99(3):621-629.

Waghmare, A. B. and S. P. Singh (1984). Sorghum-legume intercropping and the effects of nitrogen fertilization. II. Residual effect of wheat (Yields, India). Expl. Agric. 20:261-265.

Waghmare, A. B. and S. P. Singh (1984). Sorghum-legume intercropping and the effects of nitrogen fertilization: I. Yield and nitrogen uptake by crops. Expl. Agric. 20:251-259.

Wahab, A. H., M. A. Lugo-Lopez, B. M. Woo, et al. (1985). Alternatives to bench terraces on the hillsides of Jamaica. I. Soil losses. J. Agric. Univ. Puerto Rico 69:255-264.

Wahab, A. H., V. Cusumano, and G. W. Koehler (1985). The USAID agroforestry systems an alternative to meeting Haiti's food, fiber and fuel needs. Proc. Caribb. Food Crop Soc. Annu. Meet., Bridgetown, Barbados, pp. 301-304.

Wahua, T. A. T. (1985). Effects of melon (Colocynthis vulgaris) population density on intercropped maize (Zea mays) and melon. Expl. Agric. 21:281-289.

Wahua, T. A. T. and D. A. Miller (1978). Effects of intercropping on soybean N2-fixation and plant composition on associated sorghum and soybeans. Agronomy J. 70:292-295.

Wahua, T. A. T. and D. A. Miller (1978). Relative yield totals and yield components of intercropped sorghum and soybeans. Agronomy J. 70:287-291.

Wahua, T. A. T., O. Babalola, and M. E. Aken'ova (1981). Intercropping morphologically different types of maize with cowpeas: LER and growth attributes of associated cowpeas. Expl. Agric. 17:407-413. 
Walkden-Brown, S. W. and D. J. D. Banks (1987). Integrated small ruminant and cropping systems in Fiji with health as a major constraint. In Small Ruminant Production Systems in South and Southeast Asia (ed: C. Devendra). Proc. Workshop, Bogor, Indonesia, pp 289-310.

Walker, A. K. and W. R. Fehr (1978). Yield stability of soybean mixtures and multiple pure stands. Crop Sci. 18:719-723.

Walker, R. H. and G. A. Buchanan (1982). Crop manipulations in integrated weed management systems. Weed Sci. 30(Suppl.):17-24.

Walker, T. D., H. D. Orchiston, and A. F. R. Adams (1954). The nitrogen economy of grass legume associations. J. Br. Grassl. Soc. 9:249-273.

Walker, T. W., A. F. R. Adams, and H, D. Orchiston (1956). Fate of labeled nitrogen and ammonium nitrogen when applied to grass and clover grown separately and together. Soil Sci. 81:339-351.

Wall, D. A. and C. G. Campbell (1993). Competitiveness of lathyrus grown in monoculture and intercropping systems with cereals. J. Prod. Agric. 6:399-403.

Wall, G. J., E. A. Pringle, and R. W. Sheard (1991). Intercropping red clover with silage corn for soil erosion control. Can. J. Soil Sci. 71:137-145.

Wallace, S. U., T. Whitwell, J. H. Palmer, et al. (1992). Growth of relay intercropped soybean. Agronomy J. 84:968-973.

Walters, R. F. (1971). Shifting cultivation in Latin America. Food and Agric. Organization Forest Dev., Paper 17. FAO, Rome, 305 pp.

Walton, G. H. (1980). Mixed cropping for the production of feed rations. Sweet narrow-leafed lupin grown in varying proportions with either oats or wheat. Australian Agron. Conf. (Queensland Agric-College), Australian Inst. Agric. Sci., p. 269.

Wang, Q. B. and J. F. Shogren (1992). Characteristics of the crop aulownia system in China. Agric. Ecosyst. Environ. 39:145-152.

Wang, Y. F. (1979). Chung-kuoNung Yeh K'o Hsueh Sci. Agric. Sin. Peking, Nung yeh ch'u pn she. No. 3. pp. 55-59.

Wankhede N. P. and C. S. Saraf (1976). Paired row planting and intercropping pulses on the yield of cotton. Indian J. Genet. Plant Breed. 35(2):262-263.

Wankhede, N. P. and K. S. Parashar (1975). Studies on intercropping of cotton (Gossypium hirsutum L.) in spring planted sugarcane (Saccharum officinarum L.). Indian Sugar. 24(11):951-954..

Warburton, C. W. (1915). Grain crop mixtures. J. Amer. Soc. Agron. 7:20-29.

Wardle, D. A., G. W. Yates, R. N. Watson, and K. S. Nicholson (1993). Response of soil microbial biomass and plant litter decomposition to weed management strategies in maize and asparagus cropping systems. Soil Biol. Biochem. 25:857-868.

Warner, S. L. (1965). Randomized response. A survey technique for eliminating evasive answers. J. Amer. Stat. Assoc. 60:63-69.

Warner, S. L. (1971). The linear randomized response method. J. Amer. Stat. Assoc. 66:884-888

Wartiovaara, U. (1933). Uber den Sickstoffsaushalt des Hafers bet feld Masigen Mischkulturen zusammen mit der Erbse. Ztschr fur Pflanzenerahrung und Dungung 31:353-359.

Warwick, S. I. and L. Black (1981). The relative competitiveness of atrazine susceptible and resistant populations of Chenopodium album and Chenopodium strictum. Can. J. Bot. 59(5):689-693.

Waterworth, J. V. (1994). Intercropping cotton and groundnut in low and high rainfall areas in eastern Zambia. Expl. Agric. 30:461-465.

Watson, D. J. (1952). The physiological basis of variation in yield. Adv. Agron. 4:101-145.

Watters, R. F. (1960). The nature of shifting cultivation: A review of recent research. Pacific Viewpoint, I. pp. 59-99.

Way, M. J. (1975). Pest and disease status in mixed stand vs. monocultures; the relevance of ecosystem stability. In Origin of Pests, Parasite, Disease and Weed Problems (ed: J M. Charrett and G. R. Sagar). Blackwell Scientific Publications, London, pp. 127-138.

Weaver, L. A. (1924). Hogging down corn and soybeans. Missouri Agric. Expt. Sta. Bull. 224, 20 pp.

Weaver, S. E. and S. I. Warwick (1982). Competitive relationships between atrazine resistant and susceptible populations of Amaranthus retroflexus and Amaranthus powellii from Southern Ontario, Canada. New Phytol. 92(1):131-140. 
Weber, C. R. (1966). Nodulating and non-nodulating soybean isolines. II. Response to applied nitrogen and modified soil conditions. Agronomy J. 58:46-49.

Webster, C. C. and P. N. Wilson (1966). Agriculture in the Tropics. Longmans, London, 488 pp.

Weidenhamer, J. D. (1996). Distinguishing resource competition and chemical interference: Overcoming the methodological impasse. Agronomy J. 88:866-875.

Weidenhamer, J. D., D. C. Hartnett, and J. T. Romeo (1989). Density-dependent phytotoxicity: Distinguishing resource competition and allelopathic interference in plants. J. Appl. Ecol. 26:613624/

Weil, P. M. (1969). The introduction of the ox plow in central Gambia. In African Food Production Systems: Cases and Theory (ed: P. F. M. McLoughlin). Johns Hopkins Univ. Press, Baltimore, pp. 229-263.

Weil, R. R. (1982). Maize-weed competition and soil erosion in unweeded maize. Trop. Agric. (Trinidad) 59:207-213.

Weiner, J. (1982). A neighborhood model of annual-plant interference. Ecology 63:1237-1241.

Weiss, M. J., B. G. Schatz, J. C. Gardner, and B. A. Nead (1994). Flea beetle (Coleoptera: Chrysomelidae) populations and crop yield in field pea and oilseed intercrops. Environ. Entomology 23:654-658.

Welch, L. F. (1985). Rotational benefits to soybeans and following crops. World Soybean Res. Conf. III. Proc., Westview Press Boulder, CO, pp. 1054-1060.

Wells, W. C., I. R. Lazcano-Ferrat, and J. G. Waines (1986). Relative performance of tepary $\times$ common bean intercrop. Annu. Rep. Bean Improv. Coop., Geneva, N.Y, 29:114.

Welty, L. E., L. S. Prestbye, R. E. Engel, et al. (1900). Nitrogen contribution of annual legumes to subsequent barley production. Applied Agric. Res. 3:98-104.

Welty, L. E., R. L. Anderson, R. H. Delaney, and P. F. Hensleigh (1981). Glyphosate timeing effects on establishment of sod-seeded legumes and grasses. Agronomy J. 73:813-817.

Wendte, K. W. and W. R. Nave (1979). Systems for interseeding and double cropping soybeans. Trans. ASAE 22:719-723.

Werner, A. (1986). The use of a mixed cultivation system in biological weed conrol for maize and the influence of intercropping on yield of cultivated plants. Bonn 200, $4 \mathrm{pp}$.

Wesley, R. A. and F. T. Cooke (1988). Wheat-soybean double-crop systems on clay soil in Mississippi Valley area. J. Prod. Agric. 1:166-171.

Wesley, R. A., L. G. Heatherly, H. C. Pringle, III, and G. R. Topper (1988). Seedbed tillage and irrigation effects on yield of mono- and doublecrop soybean and wheat on silt loam. Agronomy J. 80:139-143.

West, C. P. and W. F. Wedin (1985). Dinitrogen fixation in alfalfa-orchardgrass pastures. Agronomy J. 77:89-94.

West, T. D. and D. R. Griffith (1992). Effect of strip-intercropping corn and soybean on yield and profit. J. Prod. Agric. 5:107-110.

Weston, L. A. (1990). Cover crop and herbicide influence on row crop seedling establishment in no-tillage culture. Weed Sci. 38:166-171.

Weston, L. A. (1996). Utilization of allelopathy for weed management in agrosystems. Agronomy J. 88:860-866.

Westphal, E. (1975). Agricultural systems in Ethiopia. Agric. Res. Rep. No. 826. College of Agric. Hail Sellassie I Univ. Agric. Univ. Wageningen, Centre for Agric. Publishing and Documentation.

Whigham, D. K. (1985). Strip and relay intercropping of soybeans. In World Soybean Research Conference III: Proc. (ed: R. Shibles). pp. 1025-1031.

White, J. G. H. (1970). Establishment of lucerne (Medicago sativa L.) in uncultivated country by sod seeding and oversowing. Proc. 9th Intl. Grassl. Congress, pp. 134-138.

White, K. J. (1988). Intercrop strategies and practices in the Bhabar Terai of Central Nepal, $2^{\text {nd }}$ ed. Sagarnath For. Dev. Project, Kathmandu, 62 pp.

White, P. G. and M. Leventis (1981). Israeli advice helped Greek polyculture project. Marine and freshwater fish farming. Fish Farm. Int. 8(2):8-11.

Whiting, K. R. and R. K. Crookston (1993). Host-specific pathogens do not account for the corn-soybean rotation effect. Crop Sci. 33:539-543. 
Whitney, A. S. and Y. Kanehiro (1967). Pathways of nitrogen transfer in some tropical legume-grass associations. Agronomy J. 59:585-588.

Whitney, A. S., Y. Kanehiro, and G. D. Sherman (1967). Nitrogen relationships of three tropical forage legumes in pure stands and in grass mixtures. Agronomy J. 59:47-50.

Whittington, W. J. and T. A. O'Brien (1968). A comparison of yield from plots sown with single species or mixtures of grass species. J. Appl. Ecol. 5:209-213.

Whyte, R. O., G. N. Leissner, and H. C. Trumble (1953). Legumes in Agriculture. FAO Agric. Studies No. 21. $367 \mathrm{pp}$.

Wicks, G. A. (1984). Integrated systems for control and management of downy brome (Bromus tectorum) in cropland. Weed Sci. 32(Suppl. 1):26-31.

Wicks, G. A., R. E. Ramsel, P. T. Nordquist, et al. (1986). Impact of wheat cultivars on establishment and suppression of summer annual weeds. Agronomy J. 78:59-62.

Widstrom, N. W, J. R. Young, W. K. Martin, and D. L. Shaver (1984). Grain and forage yields of irrigated second-crop corn seeded at five planting dates. Agronomy J. 76:883-886.

Widstrom, N. W. and J. R. Young (1980). Double cropping corn on the Coastal Plain of southeastern United States. Agronomy J. 72:302-305.

Wien, H. C. and D. Nangju (1976). The cowpea as an intercrop under cereals. IITA, Ibadan, Nigeria.

Wien, H. C. and D. Nangju (1976). The cowpea as an intercrop under cereals. Paper Symp. Intercropping in Semi-Arid Areas. Morogoro, Tanzania, 17 pp.

Wien, H. C., and J. B. Smithson (1979). The evaluation of genotypes for intercropping. Paper Intl. Intercropping Workshop, Intl. Crops Res. Inst. Semi-Arid Tropics, Hyderabad, India, 33 pp.

Wien, H. C. and J. B. Smithson (1981). The evaluation of genotypes for intercropping. In Proc. Intl. Workshop on Intercropping (ed: R. W. Willey). ICRISAT, Patancheru, India, pp. 105-116.

Wien, H. C. and R. J. Summerfield (1978). Cowpea adaptation in West Africa: Photoperiod and temperature responses in cultivars of diverse origin. Paper, Intl. Legume Conf., Kew, Enzland.

Wiggins, R. G. (1924). Experiments in crop rotation and fertilization. Cornell Univ. Agric. Expt. Sta., Bulletin 434.

Wiggans, R. G. (1935). Polebeans vs. soybeans as a companion crop with corn for silage. Agronomy J. 27:154-158.

Wijesinha, A., W. T. Federer, J. R. P. Carvalho, and T. de A. Portes (1982). Some statistical analyses for a maize and beans intercropping experiment. Crop Sci. 22: 660-666.

Wilcox, J. R. (1985). Dry matter partitioning as influenced by competition between soybean isolines. Agronomy J. 77:738-742.

Wilcox, J. R. and W. T. Schapaugh, Jr. (1978). Competition between two soybean isolines in hill plots. Crop Sci. 18:346-348.

Wilkerson, G. G., J. W. Jones, H. D. Coble, and J. L. Gunsolus (1990). SOYWEED: A simulation model of soybean and common cocklebur growth and competition. Agronomy J. 82:1003-1010.

Wilkinson, S. R. and C. F. Gross (1964). Competion for light, soil moisture and nutrients during Ladino clover establishment in orchardgrass sod. Agronomy J. 56:389-392.

Wilkinson, S. R., L. F. Welch, G. A. Hillsman, and W. A. Jackson (1968). Compatibility of tall fescue and Coastal bermudagrass as affected by nitrogen fertilization and height of clip. Agronomy J. 60:359362.

Wilkinson, S. R., O. J. Devine, D. P. Belesky, et al. (1987). No-tillage intercropped corn production in tall fescue sod as affected by sod-control and nitrogen fertilization. Agronomy J. 79:685-690.

Wille, J. E. (1958). E1 control biologico de los insectos agricolas en el Peru. Proc. X Intl. Congress Entomological (Montreal, 1956) 4 pp.

Willey, R. W. (1979). A scientific approach to intercropping research. Proc. Intl. Workshop Intercropping, ICRISAT, Hyderabad, India, pp. 4-14.

Willey, R. W. (1979). Intercropping - its importance and research needs. Part I. Competition and yield advantages. Part II. Agronomic relationships. Field Crops Abs. 32:1-10, 73-85.

Willey, R. W. (1981). Improved intercropping systems for smallholders in the semi-arid tropics, India. Proc. Increased Food Prod., World Bank, Washington, D. C., pp. 19-42.

Willey, R. W. (1981). Proc. Intl. Workshop on Intercropping. ICRISAT, Patancheru, India.

Willey, R. W. (1985). Evaluation and presentation of intercropping advantages. Expl. Agric. 21:119-133. 
Willey, R. W. and C. Garver (1981). Proc. Intl. Workshop on Intercropping, Hyderabad, ICRISAT, 401 pp.

Willey, R. W. and D. A. Lakhani (1976). Some aspects of the productivity and resource use of mixtures of sunflower and fodder radish. In Intercropping in Semiarid Areas (ed: J. H. Monyo, A. D. R. Ker, and M. Campbell). Univ. Dar es Salaam, Morogoro, IDRC, Ottawa, pp. 25-26.

Willey, R. W. and D. S. O. Osiru (1972). Studies on mixtures of maize and beans (P. vulgaris) with particular reference to plant populations. J. Agric. Sci. 79:517-529.

Willey, R. W. and E. H. Roberts (1976). Mixed cropping. In Solar Energy in Agriculture. Joint Conf. Univ. Reading and U. K. Section Intl. Solar Energy Soc., pp. 44-47.

Willey, R. W. and M. Natarajan (1978). Some aspects of resource use in sorghum/pigeonpea intercropping. Paper, Natl. Symp. on Intercropping of Pulse Crops, Indian Agric. Res. Inst., New Delhi. India.

Willey, R. W. and M. R. Rao (1980). A competitive ratio for quantifying competition between intercrops. Expl. Agric. 16:117-125.

Willey, R. W. and M. R. Rao (1981). A systematic design to examine effects of plant population and spatial arrangement in intercropping, illustrated by an experiment on chickpea. Expl. Agric. 17:6373.

Willey, R. W. and M. R. Rao (1981). A systematic design to examine effects of plant population and spatial arrangement in intercropping illustrated by an experiment on chickpea Cicer arietinum and safflower Carthamus tinctorius. Amer. Midl. Nat. 104(2):341-351.

Willey, R. W. and M. S. Reddy (1981). A field technique for separating above- and below-ground interactions in intercropping: an experiment with pearl millet. Expl. Agric. 17:257-264.

Willey, R. W. and S. B. Heath (1969). The quantitative relationships between plant population and crop yield. Adv. Agron. 21:281-321.

Willey, R. W., M. Natarajan, M. S. Reddy, and M. R. Rao (1986). Cropping systems with groundnut: resource use and productivity. Agrometeorology of Groundnut, Proc. Intl. Symp., ICRISAT, pp. 193-205.

Willey, R. W., M. Natarajan, M. S. Reddy, et al. (1983). Intercropping studies with annual crops. In Better Crops For Food, Pitman, London, pp. 83-100.

Willey, R. W., M. R. Rao, and M. Natarajan (1981). Traditional cropping systems with pigeonpea and their improvement. In Proc Intl. Workshop on Pigeonpeas, Vol. I. ICRISAT, Andhra Pradesh, India, pp. 11-25.

Willey, R. W., M. S. Reddy, and M. Natarajan (1987). Conventional cropping systems for Alfisols and some implications for agroforestry systems. In Alfisols in the Semi-Arid Tropics, Proc. Consultants' Workshop State Art Mgt., ICRISAT, pp. 155-163.

William, R. D. and G. F. Warren (1975). Competition between purple nutsedge and vegetables. Weed Sci. 23:317-323.

Williams, C. E., D. M. Pavuk, D. H. Taylor, and T. H. Martin (1995). Parasitism and disease incidence in the green cloverworm (Lepidoptera: Noctuidae) in strip-intercropped soybean agroecosystems. Environ. Entomology 24:253-260.

Williams, C. S. and R. M. Hayes (1984). Johnsongrass (Sorghum halepense) competition in soybeans (Glycine max). Weed Sci. 32:498-501.

Williams, E. D. and M. J. Hayes (1991). Growing spring cereals in a white clover (Trifolium repens) crop. J. Agric. Sci. 117:23-37.

Williams, E. D., M. J. Hayes, and R. J. Haggar (1990). Growing cereals in a base of white clover. The Council 45:245-249.

Williams, E. J. (1962). The analysis of competition experiments. Aust. J. Biol. Sci. 15:509-525.

Williams, L. E. and A. F. Schmitthenner (1962). Effect of crop rotation on soil fungus populations. Phytopathology 52:241-247.

Williams, L. E. and A. F. Schmitthenner (1963). Effect of crop rotation on yields, stalk rot, and root rot of corn. Phytopathology 53:1412-1414.

Williams, M. J., A. C. Hammond, W. T. Butts, and W. E. Kunkle (1989). Dynamics of a tropical grasslegume sward in the subtropics and its effect on animal performance. Proc. Intl. Grassl. Congr., French Grassl. Soc., Nice, pp. 1021-1022. 
Williams, P. A. and A. M. Gordon (1992). The potential of intercropping as an alternative land use system in temperate North America. Agroforestry Sys. 19:253-263.

Williams, P. A. and A. M. Gordon (1994). Agroforestry applications in forestry. The For. Chronicle 70:143-145.

Williams, W. A., C. L. Tucker, and F. P. Guerrero (1978). Competition between two genotypes of lima bean with morphologically different leaf types. Crop Sci. 18:62-64.

Williams, W. P. and J. O. Sanford (1983). Corn and wheat double-cropping system. Mississippi Agric. For. Expt. Sta. Rep. 8, No. 11.

Wilman, D. and J. E. Asiegbu (1982). The effect of clover variety, cutting interval and nitrogen application on the herbage yields, proportions and height in perennial ryegrass-white clover swards. Grass. Forage Sci. 37:1-13.

Wilsie, C. P. (1949). Evaluation of grass-legume associations, with emphasis on yields of bromegrass varieties. Agronomy J. 412-420.

Wilson, G. F. and M. O. Adeniran (1976). Some observations on land productivity under maize and cowpes in pure stands and in mixed cropping with cassava. ITTA, Ibadan, Nigeria.

Wilson, G. F. and T. L. Lawson, T. L. (1982). Increased resource exploitation through intercropping with cassava Manihot esculenta (Summary). Intercropping, In Proc. 2nd Symp. Intercropping in SemiArid Areas,.(ed: C. L. Keswani and B. J. Ndunguru). Intl. Dev. Res. Center Publ. No. 186, Ottawa, $168 \mathrm{pp}$.

Wilson, H. and A. Ovid (1993). Growth and yield responses of ginger (Zingiber officinale Roscoe) as affected by shade and fertilizer applications. J. Plant Nutrition 16:1539-1545.

Wilson, H. P. and R. H. Cole (1966). Morningglory competition in soybeans. Weeds 14:49-51.

Wilson, P. W. (1940). The Biochemistry of Symbiotic Nitrogen Fixatfon. Univ. Wisconsin Press, Madison, $302 \mathrm{pp}$.

Wilson, P. W. and O. Wyss (1937). Mixed cropping and the excretion of nitrogen by leguminous plants. Proc Soil Sci. Soc. Amer. J. 2:289-297.

Wilson, W. S. (1970). The effect of adding two contrasting green manure materials to soils of different texture on the uptake of nitrogen by S24 ryegrass. Plant Soil 33:653-660.

Windle, P. N., and Franz, E. H. (1979). The effects of insect parasitism on plant competition: greenbugs Schizaphis graminum and barley Hordeum vulgare. Ecology 60(3):521-529.

Winter, A. G. (1961). Symp. Soc. Exp. Biology 15:229-243.

Wittwer, S. (1987). Vegetable abundance: from yardlong cowpeas to bitter melons. In Feeding a Billion: Frontiers of Chinese Agriculture (ed: Sylvan Wittwer et al.). Michigan State Univ. Press, East Lansing, pp. 253-269.

Wolf, D. D. and D. Smith (1964). Yield and persistence of several legume-grass mixtures as affected by cutting frequency and nitrogen fertilization. Agronomy J. 56:130-133.

Wolfe, M. S., P. N. Minchi, and J. A. Barrett (1984). Some aspects of the developemnt of heterogenous cropping. In Cereal Production (ed: E. J. Gallagher). Proc. 2nd Intl. Summer School Agric., Butterworths, Royal Dublin Soc., London, pp. 95-104.

Woolley, J. N. and W. Rodriguez (1987). Cultivar $\times$ cropping system interactions in relay and row intercropping of bush beans with different maize plant types. Expl. Agric. 23:181-192.

Wortmann, C. S., T. Sengooba, and S. Kyamanywa (1992). Banana and bean intercropping factors affecting bean yield and land use efficiency. Expl. Agric. 28:287-294.

Wright, A. T. (1990). Yield effect of pulses on subsequent cereal crops in the northern prairies. Can. J. Plant Sci. 70:1023-1032.

Wright, D. L. and R. L. Stanley (1982). Supply nitrogen for corn with legumes. Univ. Florida Agronomy Facts \#127.

Wright, G. (1969). Tropical Agriculture. The Development of Production. Frederick A. Praeger, Pub., New York.

Wright, N. Q. (1975). My way of adjusting to the ups and downs of farming: For the mixed cropping farmer budget and cost flow planning. Proc. Lincoln Coll. Farmers Conf., 25th, pp. 92-100.

Wright, W. E. (1981). Yield response of soybeans when strip intercropped with corn. Masters Thesis, Iowa State Univ., Ames. 
Yaacob, O. and G. J. Blair (1980). The growth and nitrogen uptake of Rhodegrass grown on soils with various histories of legume cropping. Plant Soil 57:249-255.

Yadav, R. L. (1981). Intercropping pigeonpea Cajanus cajan to conserve fertilizer nitrogen in maize and produce residual effects on sugarcane. Expl. Agric. 17(3):311-315.

Yadav, R. L. (1982). Minimizing nitrate nitrogen leaching by parallel multiple cropping in long duration row crops. Expl. Agric. 18:37-42.

Yadav, R. L. (1982). Physiological analysis of yield variation of sugarcane in intercropping system at various levels of $\mathrm{N}$ and $\mathrm{P}$ (nitrogen and phosphorus, Saccharum officinarum, India). J. Res. Haryana Agric. Univ. 12:398-404.

Yadav, R. L. (1985). Improving cane yields in sugarcane and wheat companion cropping. Indian Farming $35: 17,19,21,27$.

Yadav, S. C. and A. Singh (1973). A note on studies on skip-row technique in astor with different intercropping. Indian J. Agron. 18(4):520-522.

Yadav, S. P., S. P. Singh, and V. M. Bhan (1984). Crop-weed competition in groundnut (Arachis hypogaea L.). J. Agric. Sci. (Camb.) 103:373-376.

Yadavendra, J. P., A. R. Patel, and R. M. Shah (1987). Relay intercropping of pigeonpea in groundnut. Australian Centre Intl. Agric. Res. (ACIAR), p. 246.

Yamanaka, K. and F. B. Holl (1984). Effects of $\mathrm{N}$ and seeding rate on grass-legume mixtures on coal mine spoils: Biomass production, soil factors, and $\mathrm{N}_{2}$ fixation. Agronomy J. 76:895-900.

Yamoah, C. F., P. Ay, and A. A. Agboola (1986). The use of Gliricidia sepium for alley cropping in the Southern Guinea Savanna zone of Nigeria. Intl. Tree Crops J. 3:267-279.

Yates, F. (1949). Design of rotation experiments. Commonwealth Bureau Soil Sci. Tech. Comm. No. 46.

Yates, F. (1952). Analise de uma experiencia de rotacao. Brangantia 12:213-235.

Yates, F. (1954). The analysis of experiments containing different crop rotations. Biometrics 10:324-346.

Yayock, J. Y. and J. J. Owonubi (1986). Weather-sensitive agricultural operations in groundnut production: the Nigerian situation. Agrometeorology of Groundnut, Proc. Intl. Symp., ICRISAT, pp. 213-226.

Yim, K. M., C. S. Teh, M. P. Yahya, et al. (1984). Early performance of oil palm on deep peat in RISDA Mini Estate, Parit Seraya, West Johore Intergrated Agricultural Development Project. In Proc. Workshop on Classification and Management of Peat in Malaysia 1984 (ed: E. Pushparajah). Kuala Lumpur, Malaysia, pp. 19-46.

Yip, C. P. (1975). Competitive ability of potato cultivars with major weed species. M.S. Thesis. Cornell Univ.

Yogeswara Rao, Y. and D. Narsimha Reddy (1979). Intercropping of berseem with oats for higher forage production. Indian J. Agron, 24(3):367-369.

Yonder, M. D. and R. S. Callano (1982). Preliminary study of intercropping effect on the growth of rubber seedlings Hevea, various vegetables for a intercrop. Res. J. Univ. South Mindanao, 3(2):21-24.

York, A. C. and H. D. Coble (1977). Fall panicum interference in peanuts. Weed Sci. 25:43-47.

Young III, W. C. and H. W. Youngberg (1996). Cropping systems for perennial ryegrass seed production : I. Minimum tillage establishment of rotation crops in stubble without burning. Agronomy J. 88:7377.

Young III, W. C. and H. W. Youngberg (1996). Cropping systems for perennial ryegrass seed production: II. Minimum tillage systems for changing cultivars in certified seed production. Agronomy J. 88:78-82.

Young, D., S. Miller, H. Fisher, and M. Shenk (1978). Selecting appropriate weed control systems for developing countries. Weed Sci. 26:209-212.

Young, F. L., A. G. Ogg, Jr., C. M. Boerboom, J. R. Allredge, and R. I. Papendick (1994). Integration of weed management and tillage practices in spring dry pea production. Agronomy J. 86:868-874.

Young, J. R., H. R. Gross, Jr., W. K. Martin, and W. C. McCormik (1978). Double cropping field corn in south Georgia with an insect and disease control program. Univ. Georgia Res. Bull. 227.

Yudelman, M. (1964). Africans. On the Land Economic Problem of African Agricultural Development in Southern, Central and East Africa vith Special Reference to Southern Rhodesia. Harvard Univ. Press, Cambridge. 
Yusof, M. M. (1984). Maize/groundnut intercropping: Effects of relative planting times and fertility regimes on selected vegetative and reproductive characteristics, and land equivalent ratios of associated intercrops. M. S. Thesis, Univ. Maryland, College Park.

Zaman, A. and S. Mallick (1987). Feasibility of growing second crop in winter after rainy season crop at rainfed condition in semi-arid region of West Bengal. Environ. Ecol. 5:239-243.

Zandstra, H. G. and V. R. Carangal (1977). Crop intensification for the Asian rice farmer. Agric. Mech. Asia 7:21-30.

Zarnstorff, M. E., D. S. Chamblee, J. P. Mueller, and W. V. Campbell (1990). Late-winter no-till seeding of alfalfa into autumn-suppressed tall fescue. Agronomy J. 82:255-261.

Zavitz, C. A. (1927). Forty years experiments with grain crops. Ontario Agric. Coll. Bul. 332.

Zemenchik, R. A., N. C. Wollenhaupt, K. A. Albrecht, and A. H. Bosworth (1996). Runoff, erosion, and forage production from established alfalfa and smooth bromegrass. Agronomy J. 88:461-466.

Zimdahl, R. L. (1980). Weed Crop Competition. Intl. Plant Protection Ctr., Oregon State Univ., Corvallis.

Zimmerman, M. J. O. (1983). Genetic studies on common bean in sole crop and intercropped with maize. Ph.D. Thesis, Univ. California, Riverside.

Zimmerman, M. J. O., A. A. Rosielle, and J. C. Waines (1984). Heritabilities of grain yield of common bean in sole crop and in intercrop with maize. Crop Sci. 24:641-644.

Zimmermann, M. J. O., A. A. Rosielle, J. C. Waines, and K. W. Foster (1984). A heritabiliy and correlation study of grain yield, yield components and harvest index of common bean in sole crop and intercrop. Field Crops Res. 9:109-118.

Zimmermann, M. J. O., A. A. Rosielle, K. W. Foster, and J. C. Waines (1984). Gene action for grain yield and harvest index of common bean grown in sole crop and in intercrop with maize. Field Crops Res. 12:319-329.:

Zongo, J. O., C. Vincent, and R. K. Stewart (1993). Effects of intercropping sorghum-cowpea on natural enemies of the sorghum shoot fly, Atherigona soccata (Diptera:Muscidae), in Burkina Faso. Biol. Agric. Hort. 9(3):201-213.

Zuckerman, P. S. (1973). Yorube smallholders' farming systems. Ph.D. Thesis, Univ. Reading, England. 